Caracterização Microbiológica de Cultura Desnitrificante de Reator Anaeróbio Horizontal de Leito Fixo Utilizado na Remoção de BTEX

Valquiria Ribeiro de Gusmão

Orientador: Prof ${ }^{\mathrm{a}}$. Dr ${ }^{\mathrm{a}}$. Maria Bernadete A. Varesche 
Valquiria Ribeiro de Gusmão

\section{CARACTERIZAÇÃO MICROBIOLÓGICA DE CULTURA DESNITRIFICANTE DE REATOR ANAERÓBIO HORIZONTAL DE LEITO FIXO UTILIZADO NA REMOÇÃO DE BTEX.}

Tese apresentada à Escola de Engenharia de São Carlos da Universidade de São Paulo, como parte dos requisitos para a obtenção do Título de Doutor em Hidráulica e Saneamento.

Orientadora: $\operatorname{Prof}^{\mathrm{a}}{ }^{\text {. }}$. Dr ${ }^{\mathrm{a}}$. Maria Bernadete A. Varesche Silva. 
Ficha catalográfica preparada pela Seção de Tratamento da Informação do Serviço de Biblioteca - EESC/USP

G982C

Gusmão, Valquiria Ribeiro de

Caracterização microbiológica de cultura

desnitrificante de reator anaeróbio horizontal de leito

fixo utilizado na remoção de BTEX / Valquiria Ribeiro de

Gusmão. - - São Carlos, 2005.

Tese (Doutorado) -- Escola de Engenharia de São CarlosUniversidade de São Paulo, 2005.

Área : Hidráulica e Saneamento.

Orientador: Profa. Dra. Maria Bernadete A. Varesche Silva.

1. Biodegradação. 2. Benzeno. 3. Tolueno.

4. Etilbenzeno. 5. Xilenos. 6. RAHLF. 7. Bactérias desnitrificantes. 8. Paracoccus e Pseudomonas.

I. Título. 
FOLHA DE JULGAMENTO

Candidata: Licenciada VALQUIRIA RIBEIRO DE GUSMĀO

Tese defendida e julgada em 23-09-2005 perante a Comissão Julgadora:

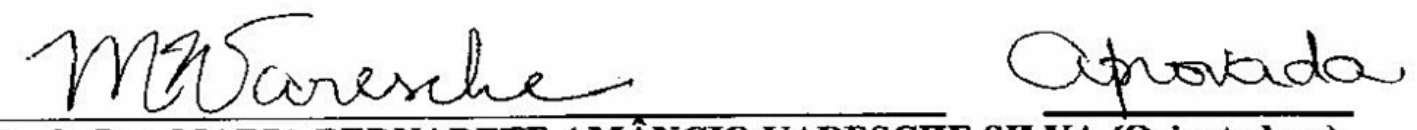

Profa. Dra. MARIA BERNADETE AMÂNCIO VARESCHE SIL VA (Orientadora)

(Escola de Engenharia de São Carlos/USP)

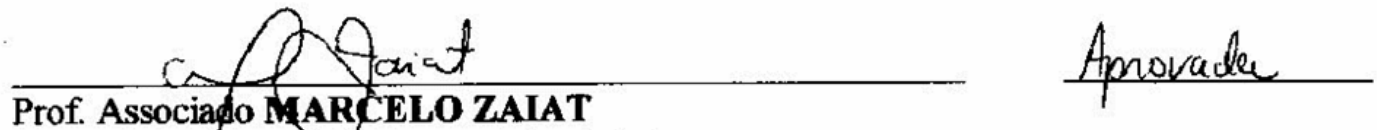

(Escola de Epgenharia de São Carlos/USP)

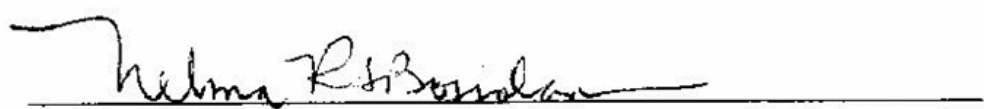

Profa. Dra. NELMA REGINA SEGNINI BOSSOLAN

(Instituto de Física de São Carlos/USP)

$$
\text { Sgavazzor }
$$

Profa. Dra. SÁvIA GAVAZZA DOS SANTOS

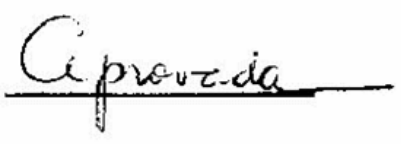

(Universidade Federal de Pernambuco/UFPE)

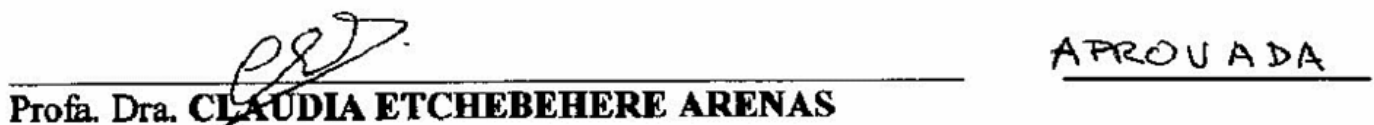

(Universidad de la Republica/Montevideo)

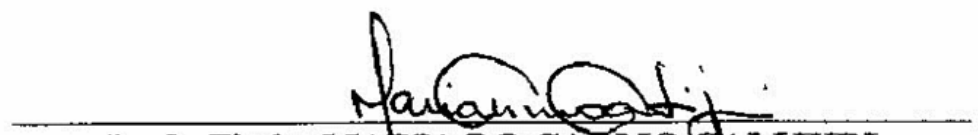

Profa. Titular MARIA DO CARMO CALIJURI

Coordenadora do Programa de Pós-Graduação em

Engenharia (Hidráulica e Saneamento) e

Presidente da Comissão de Pós-Graduação 
A DEUS

Porque tu tens sido o meu auxílio, jubiloso cantarei refugiado à sombra das tuas asas. 
Aos meus pais e irmãos

pelo amor que nos sustenta como família. 
Ao José Antônio,

por ter dividido comigo todos os momentos desta etapa, sendo, muitas vezes, os meus braços, minha mente e o meu coração. 


\section{AGRADECIMENTOS}

A Professora Bernadete pela orientação, oportunidade do trabalho, confiança em mim depositada e pelo espírito aguerrido com que conduz os seus trabalhos.

A Professora Beth Moraes, pela paciência nos valiosos conhecimentos repassados, pelo exemplo de tranqüilidade, harmonia, compreensão das relações humanas e, especialmente, pelo acolhimento.

A família LPB (amigos, professores e funcionários), pela excelente convivência e calorosas trocas de conhecimentos.

Ao Conselho Nacional de Desenvolvimento Científico e Tecnológico (CNPq) e à Fundação de Amparo a Pesquisa do Estado de São Paulo (FAPESP) pelo apoio financeiro. 
GUSMÃO, V.R. (2005). Caracterização microbiológica de cultura desnitrificante de reator anaeróbio horizontal de leito fixo utilizado na remoção de BTEX. Tese (Doutorado) - Escola de Engenharia de São Carlos, Universidade de São Paulo, São Carlos, 2005.

Hidrocarbonetos aromáticos conhecidos como BTEX (benzeno, tolueno, etilbenzeno e xilenos) estão entre os maiores problemas de poluição ambiental. Estes compostos são reconhecidos por sua recalcitrância em ambientes anóxicos, e a remoção destes hidrocarbonetos, de sítios anaeróbios contaminados é dependente da atividade de uma população de microrganismos adaptados capazes de promover a biodegradação destes compostos, nestas condições. Neste sentido, o presente trabalho buscou purificar, caracterizar e utilizar cultura desnitrificante, como inóculo para desenvolvimento de biofilme, em reator anaeróbio de leito fixo preenchido com espumas de poliuretano, além de avaliar o potencial deste biofilme em promover a biodegradação dos compostos de BTEX. Células da cultura apresentaram coloração Gram negativa, com morfologia de cocos (diplococos e cocobacilos). A cultura foi capaz de crescer, sob condições desnitrificantes, utilizando diferentes substratos. A cultura não apresentou capacidade de crescer sob condições sulfetogênicas. Velocidades de crescimento $(\mu)$ de 0,046 $\mathrm{h}^{-1} \mathrm{e}$ $0,050 \mathrm{~h}^{-1}$ e tempos de geração (Tg) de 15,1 horas e 13,9 horas foram obtidos para as células crescidas em benzeno e etilbenzeno, respectivamente. A cultura purificada foi utilizada para formar biofilme em RAHLF. Em todas as condições de alimentação as quais os reatores foram submetidos houve remoção da matéria orgânica, nitrato e dos hidrocarbonetos. A menor eficiência de remoção de hidrocarbonetos foi de 89,4\%, obtida durante a alimentação dos reatores com benzeno. A matéria orgânica (DQO) foi removida com eficiência média de 87,1\%. A eficiência média de remoção de nitrato foi de 94\%. O sequenciamento das amostras revelou que o biofilme do RAHLF1 foi formado, principalmente, por espécies de Paracoccus, Pseudomonas e Bacteroides, enquanto que no RAHLF2, alimentado com etilbenzeno, observou-se espécies dos gêneros: Paracoccus, Pseudomonas, Xanthomonas e Variovorax.

Palavras chave: biodegradação, benzeno, tolueno, etilbenzeno, xilenos, RAHLF, bactérias desnitrificantes, Paracoccus e Pseudomonas. 


\section{ABSTRACT}

GUSMÃO, V.R. (2005). Microbiologic characterization of anaerobic packed-bed reactor denitrifying culture used for BTEX removal. Ph.D. Thesis - Escola de Engenharia de São Carlos, Universidade de São Paulo, São Carlos, 2005.

The monoaromatic hydrocarbons known as BTEX (benzene, toluene, ethylbenzene, and xylene) are among the greatest environmental pollution problems. These compounds are known by their recalcitrance in anoxic environments, and the removal of these toxics from anaerobic contaminated sites depends on the presence of an adapted microbial population capable of to promote the biodegradation of these compounds under such condition. Thus, in the current study a denitrifying culture was purified, characterized and used as inoculum to form a biofilm in a in a horizontal-flow anaerobic immobilized biomass reactor filled with polyurethane foam, and to assess the potential of this biofilm to promote BTEX compounds biodegradation. Culture cells were Gram negative, with coccus (diplococcus and cocobacilli) morphology. The culture was able to grow, under denitrifying conditions, using different substrates. No growth was seen in sulfatereducing conditions. Growth velocity $(\mu)$ of $0.046 \mathrm{~h}^{-1}$ and $0.050 \mathrm{~h}^{-1}$, and generation time of 15.1 and 13.9 hours were obtained for cultures isolated in the presence of benzene and ethylbenzene, respectively. The purified culture was used to form a biofilm inside RAHLF. At all feeding conditions the reactors were submitted the organic matter, nitrate and hydrocarbons were removed. The smallest hydrocarbons removal efficiency was $89.4 \%$, obtained during benzene feeding. The organic matter (COD) was removed with mean efficiency of $87.1 \%$. The mean efficiency of nitrate removal was $94.0 \%$. Sequencing of samples showed that the RAHLF1 biofilm was composed specially for Paracoccus, Pseudomonas and Bacteroides species. Biofilm of RAHLF2 reactor, obtained from ethylbenzene feeding, was composed by Paracoccus, Pseudomonas, Xanthomonas and Variovorax species.

Keywords: biodegradation, benzene, toluene, ethylbenzene, xylenes, HAIB, denitrifying bacteria, Paracoccus and Pseudomonas 


\section{LISTA DE FIGURAS}

FIGURA 1 - Fluxograma da primeira etapa experimental dos ensaios em reatores em batelada

FIGURA 2 - Fluxograma das etapas experimentais realizadas no RAHLF1 25

FIGURA 3 - Fluxograma das etapas dos ensaios realizados no RAHLF $2 \quad 26$

FIGURA 4 - Esquema da metodologia da diluição seriada 31

FIGURA 5 - $\quad$ Reatores utilizados nos ensaios de determinação do tempo de geração

FIGURA 6 - Fotografia do RALHF instalado na câmara aclimatizada

FIGURA 7 - Microscopia de contraste de fase das morfologias predominantes observadas em amostras dos reatores alimentados com meio Zinder: bacilos, (b) cocobacilos, (c) morfologia semelhante a Methanosaeta sp. $1500 \mathrm{X}$

FIGURA 8 - Microscopia de contraste de fase das morfologias predominantes observadas em amostras dos reatores alimentados com meio Dolfing:bacilos, (b) cocobacilos, (c) morfologia semelhante a Methanosaeta sp. 1500X

FIGURA 9 - Variação temporal da concentração média de nitrato $\left(\mathrm{N}-\mathrm{NO}_{3}{ }^{-}\right)$ nos reatores em batelada alimentados com meio Zinder e Dolfing.

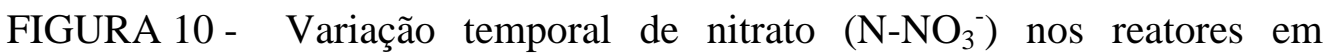
batelada alimentados com os meios Zinder e Dolfing, modificados

FIGURA 11 - Microscopia de contraste de fase das amostras do reator em batelada alimentado com meio Zinder modificado: (a) bacilos, (b) bacilos em cadeia e cocos. 1500X

FIGURA 12 - Microscopia de contraste de fase das amostras do reator em batelada alimentado com meio Dolfing modificado: (a) bacilos e cocos, (b) bacilos em cadeia, cocobacilos, cocos, bacilos curvos. $1500 \mathrm{X}$

FIGURA 13 - Microscopia de contraste de fase e fluorescência de amostras dos reatores em batelada alimentados com meio Zinder e meio Dolfing: (a) células semelhantes a Methanosaeta sp. (b) células semelhantes a Methanosarcina sp. e (c) bacilos fluorescentes.1500X

FIGURA 14 - Microscopia de contraste de fase das morfologias observadas na fase de purificação do inóculo em presença de benzeno (a, $\mathrm{b}$ - diluição $10^{-5}$ ) e etilbenzeno (c, d - diluição $10^{-5}$ ). 1500X 60 Microscopia de contraste de fase. Morfologias predominantes

FIGURA 15 - nos isolamentos em placas de Petri em presença de (a) benzeno (10mg/L) e (b) etilbenzeno (10mg/L). 1500X

FIGURA 16 - Colônias obtidas do isolamento nos meios contendo (a) benzeno e (b) etilbenzeno 
FIGURA 17 - Células Gram negativas, isoladas em (a) benzeno e (b) etilbenzeno. 1500X

FIGURA 18 - Microscopia de contraste de fase dos grânulos intracelulares observados nas células isoladas em etilbenzeno. 1500X

FIGURA 19 - Acúmulo de óxido nitroso observado no reator com acetileno

FIGURA 20 - Crescimento em diferentes substratos para as culturas isoladas em presença de benzeno e etilbenzeno, sob condições desnitrificantes

FIGURA 21 - Crescimento em diferentes substratos para as culturas isoladas em presença de benzeno e etilbenzeno, sob condições fermentativas.

FIGURA 22 - Microscopia de contraste de fase das morfologias observadas durante o monitoramento do ensaio de caracterização nutricional sob condições fermentativas. As setas indicam bacilos observados no crescimento com: (a) acetato, (b) glicose, (c) propionato, (d) butirato, (e) etanol e (f) lactato.

FIGURA 23 - Bacilos com extremidades arredondadas, em presença de benzeno (a), tolueno (b), etilbenzeno e (d) p-xileno, sob condições fermentativas.

FIGURA 24 - Microscopia de contraste de fase da cultura em meio contendo lactato $(10 \mathrm{mM})$, em condição fermentativa

FIGURA 25 - Variação temporal do crescimento celular (densidade óptica

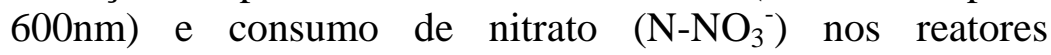
alimentados com (a) etilbenzeno, nitrato e etanol e (b) benzeno, nitrato e etanol.

FIGURA 26 - Representação gráfica da absorbância em função do tempo nos reatores alimentados com (a) benzeno, etanol e nitrato e (b) etilbenzeno, etanol e nitrato.

FIGURA 27 - Representação gráfica da absorbância em função do tempo nos reatores controles (etanol e nitrato) com células isoladas em (a) benzeno e (b) etilbenzeno.

FIGURA 28 - Pleomorfismo observado nas células dos reatores, após a retirada da recirculação da cultura em microscopia de contraste de fase(1500X).

FIGURA 29 - Microscopia de contraste de fase dos bacilos observados no biofilme dos reatores alimentados com (a) benzeno e (b) etilbenzeno.

FIGURA 30 - Variação temporal da concentração de DQO Bruta (a) e DQO Filtrada (b) durante operação do reator RAHLF1.

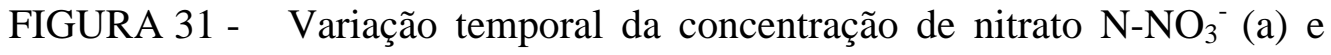
nitrito $\mathrm{N}^{-\mathrm{NO}_{2}}{ }^{-}$(b) durante operação do reator RAHLF 1. 
FIGURA 32 - Variação temporal do pH (a) e sólidos suspensos voláteis (b), durante operação do reator RAHLF1.

FIGURA 33 - Variação espacial da concentração da matéria orgânica (DQO) e ácido acético no reator RAHLF1 alimentado com benzeno (a, b, c) e tolueno (d).

FIGURA 34 Variação espacial da concentração da matéria orgânica $\left(\mathrm{DQO}_{\mathrm{f}}\right)$ e ácido acético no reator RAHLF 1 alimentado com (a) m-xileno, (b) etilbenzeno e (c) BTEX.

FIGURA 35 - Variação espacial da concentração de nitrato $\left(\mathrm{N}-\mathrm{NO}_{3}{ }^{-}\right)$e ácido acético, no reator RAHLF1 alimentado com benzeno (a, b, c), tolueno (d), etilbenzeno (e), m-xileno (f) e BTEX (g)

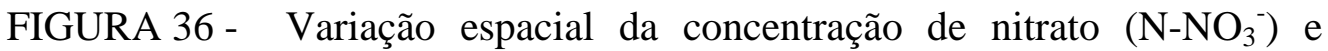
nitrito $\left(\mathrm{N}-\mathrm{NO}_{2}{ }^{-}\right)$no reator RAHLF1 alimentado com (a, b, c) benzeno em diferentes concentrações, (d) tolueno, (e) $m$ xileno, (f) etilbenzeno e (g) BTEX.

FIGURA 37 - Variação espacial da concentração de (a) benzeno e (b) tolueno, $m$-xileno, etilbenzeno e BTEX, no reator RAHLF1.

FIGURA 38 - Variação da concentração de $\mathrm{DQO}_{\mathrm{b}}$ (a), $\mathrm{DQO}_{\mathrm{f}}$ (b); $\mathrm{N}^{-\mathrm{NO}_{3}}{ }^{-}$ (c), $\mathrm{N}_{-} \mathrm{NO}_{2}^{-}, \mathrm{pH}$ (e) e SSV(f). RAHLF2 alimentado com etilbenzeno.

FIGURA 39 - Variação espacial da concentração da matéria orgânica $\left(\mathrm{DQO}_{\mathrm{f}}\right)$ e ácido acético ao longo do reator RAHLF2 alimentado com etilbenzeno a 13,1 mg/L (a), 15,1 mg/L (b) e 31,1 mg/L (c)..

FIGURA 40 - Variação espacial da concentração de etilbenzeno no reator RAHLF2.

FIGURA 41 - Variação espacial da concentração de nitrato $\left(\mathrm{N}-\mathrm{NO}_{3}{ }^{-}\right)$e nitrito $\left(\mathrm{N}-\mathrm{NO}_{2}{ }^{-}\right)$do reator RAHLF2 alimentado com etilbenzeno a 13,1 mg/L (a), 15,1 mg/L (b) e 31,1 mg/L (c).

FIGURA 42 - Variação espacial da concentração da matéria orgânica $\left(\mathrm{DQO}_{\mathrm{f}}\right)$ e ácido acético do reator RAHLF2 alimentado com tolueno (a), m-xileno (b), benzeno (c), o-xileno (d), p-xileno (e) e $\operatorname{BTEX}(\mathrm{f})$.

FIGURA 43 - Variação espacial da concentração de nitrato $\left(\mathrm{N}^{-} \mathrm{NO}_{3}{ }^{-}\right)$e ácido acético do RAHLF2 referente à alimentação com (a) benzeno, (b) tolueno e (c) $m$-xileno

FIGURA 44 - Variação espacial da concentração de $\mathrm{N}_{-} \mathrm{NO}_{3}{ }^{-}$e $\mathrm{N}-\mathrm{NO}_{2}{ }^{-}$do RAHLF2 alimentado com benzeno (a), tolueno (b), m-xileno (c), p-xileno (d), o-xileno (e), e p-xileno (f).

FIGURA 45 - Variação espacial da concentração dos hidrocarbonetos no RAHLF2 alimentado com benzeno (a), tolueno (b), m-xileno 105 (c), o-xileno (d) p-xileno (e) e BTEX (f). 
FIGURA 46 - Microscopia de varredura (5000X) mostrando a morfologia predominante observada nos biofilmes dos reatores RAHLF1 e RAHLF2: (a) bacilos e (b) cocos.

FIGURA 47 - Microscopia de contraste de fase (1500X) e eletrônica de varredura (5000X) mostrando os cordões celulares observados nas amostras obtidas dos reatores RAHLF1 e RAHLF2, em diferentes condições de alimentação: (a) RAHLF1 alimentado com BTEX, (b) RAHLF1 alimentado com tolueno, (c) RAHLF2 alimentado com benzeno e (d) reator RAHLF1 alimentado com etilbenzeno.

FIGURA 48 - Microscopia de eletrônica de varredura (5000X) de bacilos em amostra do reator RAHLF2 alimentado com benzeno (L/D 4).

FIGURA 49 - Microscopia de contrate de fase (1500X). Protozoário observado no $\mathrm{L} / \mathrm{D}=8$ do reator RAHLF2 alimentado com tolueno (a), e no reator RAHLF1 alimentado com benzeno (b).

FIGURA 50 - Microscopia de contraste de fase (1500X).Cistos observados no L/D 4 do reator RAHLF1 alimentado com $m$-xileno (a) e do reator RAHLF2 alimentado com benzeno (b).

FIGURA 51 - Microscopia óptica de contraste de fase (1500X) de bacilos observados em (a) biofilme do reator RAHLF1 alimentado com BTEX (L/D 20) e (b) crescimento em presença de etanol, observado no ensaio de caracterização nutricional, sob condições fermentativas.

FIGURA 52 - Padrão de bandas do DGGE (DNAr 16S) das amostras obtidas ao longo do reator RAHLF1 alimentados com benzeno (26,5mg/L) (a), e reator RAHLF2 alimentado com etilbenzeno (31,1 mg/L) (b). Gradiente de desnaturação 40\% a $60 \%$.

FIGURA 53 Padrão de bandas do DGGE (DNAr 16S) das amostras obtidas no $\mathrm{L} / \mathrm{D}=4$ em diferentes condições de alimentação do reator RAHLF1. A demarcação no gel mostra o principal local onde se observa um padrão de bandas diferenciado entre as amostras.

FIGURA 54 - Padrão de bandas do DGGE (DNAr 16S) das amostras obtidas do reator RAHLF2, nas diferentes condições de alimentações.

FIGURA 55 - Detalhes do DGGE (DNAr 16S) das amostras obtidas do reator RAHLF2 nas diferentes condições de alimentações: (a) comparação das amostras obtidas da alimentação com benzeno e $m$-xileno, (b) comparação das amostras obtidas da alimentação com tolueno e etilbenzeno, (c) comparação das amostras obtidas da alimentação com $o$-xileno, $m$-xileno e $p$ xileno. Gradiente de concentração do gel (40\% a 60\%) 
FIGURA 56 - DGGE (DNAr 16S) mostrando os padrões de bandas obtidos a partir das amostras dos inóculos dos reatores RAHLF1 e RAHLF2

FIGURA 57 - DGGE (DNAr 16S) das amostras obtidas em diferentes condições de alimentação dos reator RAHLF1 (a) e RAHLF2 (b). IR1= amostra do inóculo utilizado para formar o biofilme do reator RAHLF1. IR2 = amostra do inóculo utilizado para formar o biofilme do reator RAHLF2. Bz - alimentação com benzeno, Tol - alimentação com tolueno, ox - alimentação com o-xileno. $\mathrm{mx}$ - alimentação com m-xileno. px alimentação com p-xileno. etilbz - alimentação com etilbenzeno, btex - alimentação com BTEX. O retângulo destaca o padrão de bandas observado tanto no inóculo, como no biofilme. Gradiente de desnaturação do gel $40 \%$ a $60 \%$.

FIGURA 58 - DGGE (DNAr 16S) das amostras obtidas do reator RAHLF1. As setas indicam as bandas que foram recortadas $e$ seqüenciadas. 


\section{LISTA DE TABELAS}

TABELA 1 - Equações estequiométricas da oxidação anaeróbia do tolueno acoplada a redução de diferentes aceptores de elétrons.

TABELA 2. - Linhagens desnitrificantes degradadoras de hidrocarbonetos.

TABELA 3 - $\quad$ Composição do meio Zinder

TABELA 4 - C Composição da solução traço de metais do meio Zinder

TABELA 5 - Composição da solução de vitaminas do meio Zinder

TABELA 6 - Composição do meio Dolfing

TABELA 7 - $\quad$ Composição da solução traço de metais do meio Dolfing

TABELA 8 - Composição dos reatores em batelada enriquecidos com meio Zinder

TABELA 9 - C Composição dos reatores batelada enriquecidos com meio Dolfing

TABELA 10 - Composição dos frascos nos ensaios de caracterização nutricional.

TABELA 11 - Composição dos reatores utilizados para avaliação do crescimento celular.

TABELA 12 - Parâmetros avaliados durante a operação dos RAHLFs e método analítico utilizado

TABELA 13 - Condições de amplificação do PCR 48

TABELA 14 - Composição da solução do gel gradiente desnaturante. 49

TABELA 15 - Valores dos potenciais redox dos reatores em batelada alimentados com meios Zinder e Dolfing, após modificação das condições de alimentação.

TABELA 16 - Concentrações de benzeno e etilbenzeno nos reatores em batelada.

TABELA 17 - Concentrações de etilbenzeno, obtidas por cromatografia, nas triplicatas de reatores em batelada (R1, R2 e R3). 
TABELA 18 - Valores dos parâmetros de monitoramento do reator RAHLF1, obtidos durante o período de operação.

TABELA 19 - Concentrações afluentes e efluentes dos parâmetros avaliados durante os perfis realizados no reator RAHLF1, em diferentes condições de alimentação.

TABELA 20 - Valores dos parâmetros de monitoramento do reator RAHLF2, obtidos durante operação com etilbenzeno

TABELA 21 - Valores das concentrações afluentes e efluentes dos parâmetros avaliados nos perfis com diferentes 95 concentrações de etilbenzeno.

TABELA 22 - Concentrações afluentes e efluentes dos parâmetros avaliados nos perfis do RAHLF2.

TABELA 23 - Eficiências de remoção dos hidrocarbonetos obtidas para os reatores

TABELA 24 - Eficiências de remoção da matéria orgânica $\left(\mathrm{DQO}_{\mathrm{f}}\right)$ e nitrato $\left(\mathrm{N}-\mathrm{NO}_{3}{ }^{-}\right)$obtidas em diferentes condições de alimentação dos reatores

TABELA 25 - Concentração de amônia afluente e efluente do RAHLF1 109 e RAHLF2

TABELA 26 - $\quad$ Avaliação da capacidade de remoção dos compostos de BTEX pelo sistema levando-se em consideração a adsorção dos hidrocarbonetos na espuma e na 110 biopartícula. 


\section{LISTA DE QUADROS}

QUADRO 1 - $\quad$ Lista de microrganismos considerados desnitrificantes

QUADRO 2 - Revisão da literatura sobre degradação anaeróbia de BTEX com culturas puras, microcosmos e colunas

QUADRO 3- $\quad$ Estudos realizados com diferentes sistemas no tratamento de compostos tóxicos.

QUADRO 4 - Condições de preparo das soluções estoques utilizadas no enriquecimento

QUADRO 5 - Concentração de amônia no lodo (inóculo)

QUADRO 6 - Concentração de amônia inicial e final no ensaio em batelada

QUADRO 7 - Absorbâncias medidas nos ensaios de caracterização nutricional

QUADRO 8 - $\quad$ Valores das absorbâncias, concentrações de nitrato e etanol, medidos no ensaio de crescimento celular, para a cultura isolada em presença de etilbenzeno

QUADRO 9 - $\quad$ Valores das absorbâncias, concentrações de nitrato $\left(\mathrm{N}^{\left.-\mathrm{NO}_{3}{ }^{-}\right)}\right.$ e etanol, medidos no ensaio de crescimento celular, para a cultura isolada em presença de benzeno, nos reatores batelada contendo benzeno, nitrato e etanol.

QUADRO 10 - Valores das absorbâncias e concentrações de nitrato $\left(\mathrm{N}^{-} \mathrm{NO}_{3}{ }^{-}\right)$, medidos no ensaio de crescimento celular, para a cultura isolada em presença de etilbenzeno nos reatores contendo somente nitrato e etanol.

QUADRO 11 - Valores das absorbâncias e concentrações de nitrato $\left(\mathrm{N}^{-} \mathrm{NO}_{3}{ }^{-}\right)$, medidos no ensaio de crescimento celular, para a cultura isolada em presença de benzeno nos reatores contendo somente nitrato e etanol.

QUADRO 12 - Valores das medidas dos parâmetros de monitoramento obtidos no afluente e efluente do reator RAHLF1, durante o período de operação.

QUADRO 13 - Valores das medidas dos parâmetros de monitoramento obtidos no afluente e efluente do reator RAHLF2, durante o período de operação.

QUADRO 14 - Valores das medidas de concentração de amônia avaliada ao longo dos reatores RAHLF1 e RAHLF2

QUADRO 15 - Valores da adsorção dos hidrocarbonetos na biopartícula e meio suporte calculados por Nardi (2002). 
Lista de abreviaturas, siglas e símbolos

AB Alcalinidade bicarbonato

AI Alcalinidade intermediária

AP Alcalinidade parcial

AV Ácidos voláteis

BTEX Benzeno, tolueno, etilbenzeno e xilenos

CONAMA Conselho Nacional do meio ambiente

DGGE Eletroforese em gel de gradiente desnaturante

DQO Demanda química de oxigênio

$\mathrm{F}_{\mathrm{sp}}^{\mathrm{Max}} \quad$ Capacidade máxima de adorção de composto na partícula

L/D Lengh/ diameter (relação extensão/diâmetro)

PCR Reação de polimerização em cadeia

pH Potencial hidrogeniônico

Q Vazão de líquido

$\mathrm{R}^{2} \quad$ Coeficiente de correlação

RAHLF Reator anaeróbio horizontal de leito fixo

RDNA Redução disassimilativa de nitrato a amônia

rpm Rotações por minuto

SSV Sólidos suspensos voláteis

STV Sólidos totais voláteis

TDH Tempo de detenção hidráulica

TDH Tempo de detenção hidráulica

Tg Tempo de geração

UASB Reator anaeróbio de fluxo ascendente e manta de lodo

$\mu \quad$ velocidade específica de crescimento celular 


\section{SUMÁRIO}

RESUMO V V

ABSTRACT vi

LISTA DE FIGURAS vii

LISTA DE TABELAS Xii

LISTA DE QUADROS Xiv

LISTA DE ABREVIATURAS E SIGLAS E SÍMBOLOS XV XV

1 INTRODUÇÃO

2 OBJETIVOS 5

2.1. Objetivo Geral 5

2.2. Objetivos específicos

3 REVISÃO BIBLIOGRÁFICA 6

$\begin{array}{ll}3.1 \text { Microrganismos desnitrificantes } & 6\end{array}$

3.2. Estudos com culturas puras desnitrificantes, degradadoras de BTEX 8

3.3 Estudos com culturas enriquecidas 15

3.3.1 - Estudos em microcosmos e colunas 15

3.3.2 Estudos em biorreatores 17

$\begin{array}{ll}3.4 \text { Considerações finais } & 21\end{array}$

4 MATERIAL E MÉTODOS 23

4.1 Inóculo 27

4.2 Ensaios de Enriquecimento 27

4.3 Purificação do inóculo 31

4.4 Purificação em placa de Petri 31

4.5 Aumento da massa celular 32

4.6 Manutenção das culturas

4.7. Caracterização nutricional das culturas 33

4.8 Ensaios em reatores batelada 35

4.8.1 Determinação do tempo de geração das culturas 35

4.9 Ensaios em reator anaeróbio horizontal de leito fixo (RAHLF) 37

4.9.1 Configuração do reator 37

4.9.2 Imobilização das culturas nos reatores 38

4.9.3 Alimentação dos reatores 38

4.9.3.1 Solução etanólica com BTEX 38 
4.9.4 Manutenção do reator

4.9.5 Estratégias utilizadas na operação dos reatores 39

4.9.6 Análises realizadas no RAHLF 40

4.10 Metodologias utilizadas nos ensaios $\quad 40$

4.10.1 Exames microscópicos $\quad 40$

4.10.2 Coloração de Gram 41

4.10.3 Análises Cromatográficas 41

4.10.3.1 Óxido nitroso e metano 41

4.10.3.2 Análise de BTEX 41

4.10.3.3 Ácidos voláteis por cromatografia 43

4.10.3.4 Análise de etanol 44

4.10.4 Análises Físico-químicas $\quad 44$

4.10.4.1 DQO, nitrato, nitrito, nitrogênio amoniacal e sólidos suspensos voláteis 44

4.10.4.2 Alcalinidade e ácidos voláteis por titulometria 45

4.10.5 Potencial Redox 46

4.10.6 Métodos moleculares 46

4.10.6.1 Extração de DNA 46

4.10.6.2 Amplificação do DNA Ribossomal 16S (PCR) 47

4.10.6.3 Eletroforese em gel de gradiente desnaturante (DGGE) 48

4.10.6.4 Clonagem e sequenciamento 50

4.10.6.4.1 Sequenciamento das bandas $\quad 51$

5 RESULTADOS E DISCUSSÃO 52

5.1 Escolha do Inóculo 52

5.2 Escolha dos meios de cultivos 53

5.3 Purificação do inóculo $\quad 59$

5.4 - Confirmação do metabolismo desnitrificante 62

5.5 Caracterização nutricional das culturas $\quad 65$

5.6 Determinação do tempo de geração das culturas 69

$\begin{array}{ll}5.7 \text { Avaliação do consumo de etilbenzeno } & 73\end{array}$

$\begin{array}{ll}5.8 \text { Imobilização das culturas desnitrificantes no RALHF } & 74\end{array}$

59 Monitoramento dos Reatores de Leito Fixo 76

$\begin{array}{ll}\text { 5.9.1 Considerações } & 76\end{array}$

$\begin{array}{ll}\text { 5.9.2 Operação do reator RAHLF1 } & 77\end{array}$

5.9.3 Operação do reator RAHLF2 92 
5.9.3.1 Alimentação do RAHLF2 com etilbenzeno em diferentes concentrações

5.9.3.2 Alimentação do RAHLF2 com tolueno, benzeno, $m$-xileno, $o$-xileno, $p$ xileno e BTEX

5.10 Comparação entre os reatores RAHLF1 e RAHLF2

5.11 Análises complementares

5.11.1 - Avaliação da formação de amônia ao longo do reator 108

5.11.2 Avaliação da adsorção de BTEX

5.11.3 - Avaliação da concentração de BTX na saída de gás

6 EXAME MICROSCÓPICO DOS REATORES

7 ANÁLISE MOLECULAR

7.1 Sequenciamento

8. CONCLUSÕES

9. SUGESTÕES

10. REFERÊNCIAS

Apêndice A

Apêndice B

Apêndice C 155

Apêndice D 156

Apêndice E 157

Apêndice F 158

Apêndice $G$ 159

Apêndice H 160

Apêndice I 162

Apêndice $J$ 171

Apêndice K 


\section{INTRODUÇÃO}

Mundialmente, os compostos tóxicos antropogênicos têm se tornado contaminantes ubíquos de solos e águas, devido ao resultado do desconhecimento humano na utilização segura de produtos químicos, descuido na manufatura de compostos sintéticos, acidentes ocasionais e disposição inadequada de resíduos químicos. Esta contaminação ocorre principalmente, a partir de vazamentos em dutos e tanques de armazenamentos subterrâneos de combustível, atividades de mineração e uso de defensivos agrícolas. Estes químicos são encontrados no ambiente, algumas vezes individualmente, mas mais freqüentemente, em misturas complexas, e muitos são potencialmente tóxicos ou carcinogênicos.

Entre os principais contaminantes das águas subterrâneas estão os compostos aromáticos, especialmente os hidrocarbonetos monoaromáticos denominados BTEX (benzeno, tolueno, etilbenzeno e xilenos). A presença destes compostos na natureza causa impacto ambiental devido ao potencial dos mesmos em causar danos aos seres vivos.

O benzeno atua no sistema reprodutivo podendo causar deformações no feto (efeito teratogênico), disfunções sexuais como infertilidade e aborto, podendo ainda agir nos sistemas neurológico e imunológico. Mas, o principal prejuízo deste tóxico para o ser humano é sua comprovada carcinogenicidade. O tolueno está associado com as disfunções hepáticas e gastrointestinais sendo, também, teratogênico. O etilbenzeno causa prejuízo ao sistema respiratório, além de provocar irritação nos olhos e desmaios. Os distúrbios mais comuns observados com a exposição crônica aos vapores de xilenos são fadiga, dor de cabeça, irritabilidade, fraqueza, perda de memória, sonolência, distúrbio do humor e do equilíbrio, zumbido, náuseas, e perda do apetite. Em concentrações elevadas pode levar a inconsciência e morte, por depressão do sistema nervoso central (Ribeiro, 2005).

Estes compostos são componentes do petróleo e são, desta forma, encontrados também na gasolina e outros combustíveis. Além disso, milhões de toneladas de benzeno, tolueno, etilbenzeno e xilenos são amplamente utilizados a cada ano na industria química (Phelps e Young, 2001). O benzeno é utilizado na produção de materiais sintéticos como borrachas, plásticos, $\mathrm{Nylon}^{\circledR}$ além de inseticidas e tintas. O tolueno é usado como solvente na produção de tintas, resinas, colas e óleos. O etilbenzeno é, principalmente, empregado na produção de estireno. Os xilenos, por sua 
vez, são utilizados como solventes em borrachas e por curtumes, nos processos de tingimento de couro (Ribeiro, 2005). Assim, devido a grande produção, transporte e utilização, parte destes compostos são perdidos para o ambiente.

A presença de compostos tóxicos em águas subterrâneas vem deixando os níveis de potabilidade da água cada vez mais baixos. De acordo com o estabelecimento da portaria número 518 de março de 2004, do Ministério da Saúde, os valores máximos permitidos para estes poluentes são de $5 \mu \mathrm{g} / \mathrm{L}$ para benzeno, $170 \mu \mathrm{g} / \mathrm{L}$ para tolueno, $200 \mu \mathrm{g} / \mathrm{L}$ para etilbenzeno e $300 \mu \mathrm{g} / \mathrm{L}$ para o xileno.

Nas últimas décadas, em virtude da escassez do petróleo e do excesso de monóxido de carbono, no ar atmosférico nos grandes centros urbanos, alguns países, entre eles o Brasil, passaram a utilizar como combustível alternativo a mistura de álcool e gasolina. No Brasil, esta mistura corresponde entre $20 \%$ a $24 \%$ de etanol em massa, diferenciando-se da gasolina comercializada em outros países. Até recentemente, somente o efeito negativo da presença de etanol na gasolina era reconhecido, pois, o álcool favorece a solubilização dos hidrocarbonetos monoaromáticos e, conseqüentemente, melhor deslocamento da pluma de contaminação destes compostos no lençol freático (Silva et al., 2002). Recentemente, uma pesquisa sobre desenvolvida no Departamento de Engenharia Ambiental da Universidade Federal de Santa Catarina revelou o benefício da combinação etanol/gasolina (Schneider et al., 2005). Nesta pesquisa, uma área de $1,5 \mathrm{~m}^{2}$ de água subterrânea foi contaminada por gasolina comercial (24\% de etanol) e a área foi monitorada durante 6 anos. Segundo os autores, o efeito negativo da presença do etanol na gasolina ocorre porque os microorganismos degradam o etanol de forma mais intensa que os demais compostos orgânicos da gasolina, permitindo que a pluma dos hidrocarbonetos aumente continuamente. No decorrer dos experimentos, os pesquisadores verificaram que a elevada concentração de biomassa, remanescente da degradação do etanol acelerava significativamente o processo de degradação dos outros contaminantes da gasolina. Assim, três anos depois do derramamento "induzido", a presença do etanol fez com que a redução do benzeno no local próximo à fonte do vazamento fosse de apenas $10 \%$. Mas nos dois anos seguintes, quando o álcool havia sido completamente biodegradado, essa redução passou para 99\%. Os autores concluíram que a biomassa remanescente acelerou a redução do benzeno no período seguinte, pois os microorganismos estavam ávidos por substratos e os únicos disponíveis eram os outros contaminantes. Com esta pesquisa, constatou-se o efeito positivo do etanol presente na gasolina. 
Devido ao número alarmante de vazamentos de tanques de armazenamento de combustível subterrâneos, a contaminação de aqüíferos a partir desses derramamentos tem sido assunto de grande interesse nas últimas décadas (Borden et al., 1986; Hunt et al., 1988; Mackay e Cherry, 1989; Little et al., 1992; Capuano e Johnson, 1996; Corseuil e Alvarez, 1996; Bicalho, 1997). No Brasil, segundo a AGÊNCIA NACIONAL DO PETRÓLEO - ANP (Despacho $n^{\circ}$ 536, 15/09/2000), havia 29.310 postos de gasolina em funcionamento. Por isso, as preocupações relacionadas ao potencial de contaminação de águas subterrâneas, por derramamento de combustível, vêm crescendo em diversas cidades brasileiras. São Paulo e Curitiba, por exemplo, possuem legislações sobre o tema e, em Joinville, a prefeitura realizou estudo com 65 postos da cidade, onde apenas um deles não possuía qualquer tipo de vazamento (Corseuil e Marins, 1997).

Uma vez que o vazamento no ambiente tenha ocorrido, a remoção dos hidrocarbonetos aromáticos de sítios contaminados depende da atividade de microrganismos aeróbios e anaeróbios, capazes de metabolizar esses compostos. No entanto como a concentração de oxigênio na água subterrânea diminui nestes sítios, devido ao metabolismo dos microrganismos aeróbios (Gibson e Subramanian, 1984; Ridgway et al., 1990), aqüíferos contaminados se tornam anóxicos e dependentes da subsequente atividade de bactérias anaeróbias.

Até 1984, pensava-se que a degradação de hidrocarbonetos aromáticos não ocorria na ausência de oxigênio molecular (Reinhard e Goodman, 1984). Entretanto, nos últimos anos, vários estudos demonstraram a capacidade de culturas puras em degradar anaerobicamente tolueno (Dolfing et al., 1990; Evans et al., 1991; Fries et al., 1994; Rabus e Widdel; 1995; Hess et al., 1997), etilbenzeno (Rabus e Widdel, 1995; Ball et al., 1996), e o-, $m$ - e p-xilenos (Dolfing et al., 1990; Rabus e Widdel, 1995; Hess et al., 1997). A degradação de benzeno foi demonstrada com culturas enriquecidas sob diferentes condições redutoras. (Edwards e Grbic-Galic, 1992; Lovley et al., 1995; Kazumi et al., 1997; Burland e Edwards, 1999). Todos estes estudos estabeleceram claramente a biodegradabilidade anaeróbia do BTEX.

Nesse contexto, portanto, fica evidente a possibilidade de tratamento biológico anaeróbio das águas contaminadas, sendo fundamental a realização de pesquisas, com a finalidade de restaurar a qualidade das águas, até níveis de potabilidade previstos pelos órgãos de fiscalização do meio ambiente, e que busquem o desenvolvimento de 
tecnologias, visando a minimização dos custos e maximização da eficiência de remoção de poluentes.

Uma proposta para o tratamento de águas contaminadas vem sendo amplamente realizada no Laboratório de Processos Biológicos - LPB, do Departamento de Hidráulica e Saneamento da Escola de Engenharia de São Carlos - USP. Neste laboratório, o reator anaeróbio horizontal de leito fixo, com biomassa imobilizada (RAHLF), tem demonstrado ser uma ferramenta adequada para o tratamento de compostos tóxicos, apresentando alta eficiência na degradação destes poluentes, incluindo BTEX (Damianovic, 1997; Bolãnos et al., 2001; Nardi, 2002; Oliveira et al., 2004; Cattony, 2005; Fernandes, 2005; Ribeiro, 2005).

Outro alvo de grande preocupação em relação à contaminação de águas é a presença de nitrogênio, nas formas de nitrato e nitrito nestes locais. O nitrito reage com aminas secundárias para produzir nitrosaminas, um composto considerado altamente carcinogênico. Rajapakse e Scutt (1999) afirmaram que os riscos à saúde, decorrentes da presença de nitrato e nitrito, em água utilizada para consumo humano, vão desde hipertrofia de tireóide, a 15 diferentes tipos de câncer, incluindo defeitos de nascimento e hipertensão em adultos.

Nos últimos anos, muitas tecnologias diferentes têm sido desenvolvidas para solucionar o problema de nitrato na água residuária, subterrânea ou de abastecimento. Nestes sistemas de tratamento, a remoção dos compostos de nitrogênio está, geralmente, acoplada por processos biológicos de desnitrificação. Além da remoção de nitrato, a desnitrificação é importante em sistemas de tratamento de águas residuárias, uma vez que este processo estimula a remoção da matéria orgânica, quando o oxigênio se torna limitante no meio. Este processo requer a ação de grupos especializados de microrganismos, designados bactérias desnitrificantes. Essas bactérias são freqüentemente isoladas de sedimento, solo e ambientes aquáticos, e a capacidade desnitrificante está presente em muitos grupos filogenéticos (Gamble et al., 1977). Neste sentido, numerosos esforços vêm sendo realizados para melhorar a remoção de nitrato de forma eficiente e econômica de águas residuárias e vários desses estudos são desenvolvidos no sentido de otimizar os sistemas de biorremediação.

Pelo exposto, este trabalho visa aprimorar os conhecimentos dos estudos sobre a utilização de benzeno, tolueno, etilbenzeno e xilenos, por cultura desnitrificante, em reator anaeróbio horizontal de leito fixo, e obter informações sobre a microbiologia da cultura utilizada para formar o biofilme deste reator. 


\section{OBJETIVOS}

\subsection{Objetivo Geral}

1. Este trabalho teve como objetivo geral avaliar a capacidade da cultura desnitrificante purificada, na remoção de diferentes concentrações benzeno, tolueno, etilbenzeno e xilenos, em reator anaeróbio horizontal de leito fixo.

\subsection{Objetivos Específicos}

Os objetivos específicos foram:

1. Verificar o potencial do lodo granulado de reator anaeróbio de fluxo ascendente e manta de lodo (UASB), usado no tratamento de água residuária de abatedouro de aves, em servir como inóculo para obtenção de bactérias desnitrificantes;

2. Definir uma condição nutricional para crescimento para as bactérias desnitrificantes;

3. Purificar cultura desnitrificante capaz de crescer em presença de BTEX;

4. Estudar as características morfológicas e fisiológicas da cultura purificada;

5. Avaliar a capacidade do biofilme adaptado à presença contínua dos hidrocarbonetos em remover estes compostos;

6. Avaliar a capacidade do biofilme em promover a remoção dos compostos de BTEX, separadamente, e em curtos períodos de operação do reator.

7. Avaliar a dinâmica da população de microrganismos do biofilme através do DGGE

8. Identificar, através do sequenciamento, as principais comunidades de microrganismos presentes no biofilme, envolvidas com o processo de remoção de BTEX. 


\section{REVISÃO DA LITERATURA}

\subsection{Microrganismos Desnitrificantes}

A desnitrificação se caracteriza pela redução de nitrato a óxidos de nitrogênio, principalmente nitrogênio gasoso. O passo inicial na desnitrificação é a redução de nitrato a nitrito. Em seqüência, nitrito é reduzido a óxido nítrico, um óxido de nitrogênio gasoso. Uma vez que oxido nítrico foi produzido, ele é reduzido a óxido nitroso, que por sua vez, é convertido a nitrogênio gasoso.

A maioria dos organismos desnitrificantes é Gram negativos, no entanto, bactérias desnitrificantes Gram positivas estão também bem representadas neste grupo.

Os microrganismos capazes de realizar a desnitrificação estão amplamente distribuídos na natureza, incluindo habitats tais como solo, água doce e do mar, sedimentos, sistemas de tratamento de resíduos, e trato gastrointestinal de animais. Desta forma, qualquer restrição da atividade de redução do nitrato em ambientes naturais não é, provavelmente, causada pela falta de microrganismos, mas sim pelas limitações das condições ambientais (principalmente oxigênio) que regulam estes processos.

A capacidade de desnitrificação pode ser observada em ampla variedade de grupos fisiológicos e taxonômicos. A maioria das bactérias desnitrificantes caracterizadas estão incluídas no grupo conhecido como Proteobacteria (bactéria púrpura) que apresenta 5 subdivisões $(\alpha, \beta, \gamma, \delta, \varepsilon)$. Os organismos desnitrificantes são encontrados em 4 destas subdivisões. O quadro 1 mostra uma lista de microrganismos que foram sugeridos para serem incluídos como desnitrificantes. O principal critério de inclusão nesta lista foi a capacidade de formar óxidos de nitrogênio gasoso.

Baseando-se nos isolamentos mais freqüentes, as espécies de Pseudomonas e Alcaligenes são, provavelmente, as de maior significância em muitos ambientes (Brown, 1988). Entre as Pseudomonas, Pseudomonas fluorescens, especialmente o biotipo II, parece ser a mais prevalente em solos. A predominância dessas Pseudomonas 
é, provavelmente, devido à sua versatilidade e competitividade por fones de carbono no solo e água.

Quadro 1 - Lista de microrganismos considerados desnitrificantes.

\begin{tabular}{|c|c|}
\hline $\begin{array}{l}\text { Archaea } \\
\text { Haloarcula } \\
\text { Halobacterium } \\
\text { Haloferax } \\
\text { Ferroglobus } \\
\text { Fyrobaculum }\end{array}$ & $\begin{array}{l}\text { Oligelia } \\
\text { Raistonial (Alcaligenes) } \\
\text { Fubrivina } \\
\text { Thauera } \\
\text { Thermothrix } \\
\text { Thiobacilius } \\
\text { Vogeselia } \\
\text { Zoogloea }\end{array}$ \\
\hline Bactéria Gram Negativa & Subdivisão Gama \\
\hline $\begin{array}{l}\text { Aquifex } \\
\text { Fexibacter I (Cytophaga) } \\
\text { Empedobacter } \\
\text { Favobacterium } \\
\text { Sphingobacterium } \\
\text { Spnechocystis sp. PCC } 6803 \\
\text { Bactéria púrpura } \\
\text { Subdivisão alfa } \\
\text { Agrobacterium } \\
\text { Aquaspirillum } \\
\text { Azospirilimm } \\
\text { Blastobacter } \\
\text { Bradyrinobium } \\
\text { Gluconobacter } \\
\text { Hyphomicrobium } \\
\text { Magnetospirilum } \\
\text { Titrobacter } \\
\text { Faracoccus } \\
\text { Fseudomonas (G-179) } \\
\text { Fhizobium } \\
\text { Fhodobacter } \\
\text { Fhodoplanes } \\
\text { Fhodopseudomonas } \\
\text { Roseobacter } \\
\text { Sinorhizobium (Rhizobium) } \\
\text { Thiobacilius }\end{array}$ & $\begin{array}{l}\text { Acinetobacter } \\
\text { Alteromonas } \\
\text { Azomonas } \\
\text { Beggiatoa } \\
\text { Deleya } \\
\text { Halomonas } \\
\text { Marinobacter } \\
\text { Moraxella } \\
\text { Pseudoalteromonas } \\
\text { Pseudomonas } \\
\text { Fugamonas } \\
\text { Shewanelia } \\
\text { Thioploca } \\
\text { Thiomargarita } \\
\text { Xanthomonas } \\
\text { Subdivisão Delta } \\
\text { Nenhuma } \\
\text { Subdivisão Epsilon } \\
\text { Woinelia } \\
\text { Campylobacter } \\
\text { Thiomicrospira } \\
\text { Outras } \\
\text { Gram positivas }\end{array}$ \\
\hline $\begin{array}{l}\text { Subdivisão Beta } \\
\text { Achromobacter } \\
\text { Acidovorax } \\
\text { Alcaligenes } \\
\text { Azoarcus } \\
\text { Brachymonas } \\
\text { Burhholderia } \\
\text { Chromobacterium } \\
\text { Comamonas } \\
\text { Eihenella } \\
\text { Hydrogenophaga } \\
\text { Janthinobacterium } \\
\text { Kingelia } \\
\text { Microvirgula } \\
\text { Neisseria } \\
\text { Mitrosomonas } \\
\text { Ochrobactrum }\end{array}$ & $\begin{array}{l}\text { Bacilius } \\
\text { Corynebacterium } \\
\text { Franhia } \\
\text { Dactiosporangium } \\
\text { Dematophilus } \\
\text { Gemella (Listeria) } \\
\text { Jonesia (Wineosporla } \\
\text { Micromonospora } \\
\text { Microtetraspora } \\
\text { Wocardia } \\
\text { Filimelia } \\
\text { Propionibacterium } \\
\text { Saccharomonospora } \\
\text { Saccharothrix } \\
\text { Spirrilospora } \\
\text { Streptompces } \\
\text { Streptosporangum }\end{array}$ \\
\hline
\end{tabular}

Fonte: Shapleigh.(2000)

Bactérias desnitrificantes utilizam todas as três classes de fontes de energia, ou seja, orgânica (organotróficos), inorgânica (litotróficos), e luz (fototróficos). Os 
substratos orgânicos são as fontes de energia mais comumente utilizadas por este grupo (Zehnder, 1988). Além da variedade de produtos naturais que são tipicamente utilizados como fonte de carbono, a decomposição de certos compostos antropogênicos, por bactérias desnitrificantes, tem sido observada. Nos últimos anos, tem-se consolidado que bactérias desnitrificantes podem metabolizar compostos aromáticos.

Bactérias desnitrificantes degradadoras de compostos aromáticos têm sido isoladas, e muitas pertencem ao gênero Azoarcus e Thauera, (Fries et al., 1994; Anders et al, 1995; Springer et al., 1998). O uso destes microrganismos na degradação de poluentes é um atrativo para os pesquisadores levando-se em conta as seguintes considerações: (a) bactérias desnitrificantes apresentam maior velocidade de crescimento e são mais facilmente cultiváveis em ambientes anóxicos; (b) o entendimento da genética está bem estabelecido e (c) devido a solubilidade e baixo custo, o nitrato está entre os aditivos mais confiáveis que pode ser utilizado em áreas poluídas para favorecer o processo anaeróbio facultativo (Zehnder, 1988).

\subsection{Estudos com culturas puras desnitrificantes, degradadoras de BTEX}

Os hidrocarbonetos são compostos orgânicos altamente reduzidos. Nos organismos quimiotróficos, os equivalentes reduzidos gerados durante a transformação de hidrocarbonetos a intermediários metabólicos necessitam ser transferidos para um aceptor de elétrons de alto potencial redox para permitir a conservação de energia para crescimento. Pesquisas de laboratório mostram que a degradação anaeróbia de BTEX pode ocorrer sob ampla faixa de potenciais redox, as quais podem ser mediadas por bactérias redutoras de nitrato, sulfato ou ferro (III), bem como por consórcios fermentativo e metanogênico (Stoner, 1994). A utilização preferencial dos aceptores de elétrons ocorre em ordem decrescente, de acordo com o potencial de oxidação do aceptor de elétrons (oxigênio $>$ nitrato $>$ ferro $>$ sulfato $>$ dióxido de carbono) e, em geral, a cinética de oxidação de hidrocarbonetos é mais rápida para aceptores de elétrons com maiores potenciais de oxidação.

De acordo com Heider et al. (1999), os balanços das reações para a oxidação do tolueno com estes diferentes aceptores finais de elétrons demonstram que, sob condições desnitrificantes, a variação da energia livre produzida por este composto 
$\left(\Delta G^{\circ}=-3554 \mathrm{~kJ}\right)$ é alta, quando comparada com a variação de energia livre gerada na presença de outros aceptores de elétrons (Tabela 1).

Tabela 1 - Equações estequiométricas da oxidação anaeróbia do tolueno acoplada a redução de diferentes aceptores de elétrons.

\section{Bactéria desnitrificante:}

$\mathrm{C}_{7} \mathrm{H}_{8}+7,2 \mathrm{NO}_{3}{ }^{-}+0,2 \mathrm{H}^{+} \longrightarrow 7 \mathrm{HCO}_{3}{ }^{-}+3,6 \mathrm{~N}_{2}+0,6 \mathrm{H}_{2} \mathrm{O} \quad \Delta G^{\circ}=-3554 \mathrm{~kJ}(\mathrm{~mol}$ tolueno) $)^{-1}$

\section{Bactéria redutora de ferro III:}

$\mathrm{C}_{7} \mathrm{H}_{8}+94 \mathrm{Fe}(\mathrm{OH})_{3} \longrightarrow 7 \mathrm{Fe} \mathrm{CO}_{3}+29 \mathrm{Fe}_{3} \mathrm{O}_{4}+145 \mathrm{H}_{2} \quad \Delta G^{\circ}=-3398 \mathrm{~kJ}(\mathrm{~mol}$ tolueno $)^{-1}$

\section{Bactéria redutora do íon sulfato:}

$\mathrm{C}_{7} \mathrm{H}_{8}+4,5 \mathrm{SO}_{4}{ }^{2-}+3 \mathrm{H}_{2} \mathrm{O} \longrightarrow 7 \mathrm{HCO}_{3}{ }^{-}+2,5 \mathrm{H}^{+}+4,5 \mathrm{HS}^{-} \quad \Delta G^{\circ}=-205 \mathrm{Kj}(\mathrm{mol}$ tolueno $)^{-1}$

\section{Consórcio metanogênico:}

Reações catalisadas por bactérias próton redutoras (a) e metanogênicas (b, c)

(a) $\mathrm{C}_{7} \mathrm{H}_{8}+9 \mathrm{H}_{2} \mathrm{O} \longrightarrow \mathrm{HCO}_{3}^{-}+3 \mathrm{H}_{3} \mathrm{C}-\mathrm{COO}^{-}+4 \mathrm{H}^{+}+6 \mathrm{H}_{2} \quad \Delta G^{\circ}=+166 \mathrm{~kJ}(\mathrm{~mol}$ tolueno) ${ }^{-1}$

(b) $6 \mathrm{H}_{2}+1,5 \mathrm{HCO}_{3}^{-}+1,5 \mathrm{H}^{+} \longrightarrow 1,5 \mathrm{CH}_{4}+4,5 \mathrm{H}_{2} \mathrm{O} \quad \Delta G^{\circ}=-203 \mathrm{~kJ}(6 \mathrm{mols}$ de $\left.\mathrm{H}_{2}\right)^{-1}$

(c) $3 \mathrm{H}_{3} \mathrm{C}-\mathrm{COO}^{-}+3 \mathrm{H}_{2} \mathrm{O} \longrightarrow 3 \mathrm{CH}_{4}+3 \mathrm{HCO}_{3}^{-} \Delta G^{\circ}=-93 \mathrm{~kJ}$ (3 mols de acetato $)^{-1}$

Soma: $\mathrm{C}_{7} \mathrm{H}_{8}+7,5 \mathrm{H}_{2} \mathrm{O} \longrightarrow 4,5 \mathrm{CH}_{4}+2,5 \mathrm{HCO}_{3}{ }^{-}+2,5 \mathrm{H}^{+} \quad \Delta G^{\circ}=-131 \mathrm{~kJ}(\mathrm{~mol} \mathrm{de}$ tolueno) $)^{-1}$

Fonte: Heider et al.(1999).

As espécies desnitrificantes descritas mineralizam variedade de alquilbenzenos, incluindo tolueno, $m$-xileno, etilbenzeno, propilbenzeno, $p$-etiltolueno e $p$-cimeno (Dolfing et al., 1990; Evans et al., 1991; Fries et al., 1994; Rabus e Widdel, 1995; Ball et al., 1996). Baseado na comparação de seqüências do RNAr 16S, estas linhagens são atualmente afiliadas ao gênero Thauera e Azoarcus, dentro da subclasse $\beta$ Proteobacteria. As linhagens desnitrificantes conhecidas exibem espectro amplo de utilização de substratos para compostos aromáticos polares, mas são restritas para poucos hidrocarbonetos aromáticos. Algumas destas linhagens usam mais de um hidrocarboneto aromático como substrato, como pode ser observado na Tabela 2.

Bactérias desnitrificantes crescem relativamente rápidas em alquibenzenos. A velocidade máxima de crescimento para a linhagem Thauera aromática K172 em 
tolueno foi de $0,12 \mathrm{~h}^{-1}$, com tempo de geração de 6 horas, correspondendo a $70 \%$ da velocidade de crescimento obtida com benzoato como substrato.

Tabela 2. - Linhagens desnitrificantes degradadoras de hidrocarbonetos.

\begin{tabular}{|c|c|c|}
\hline $\begin{array}{c}\text { Bactéria desnitrificante } \\
\text { (subclasse } \beta \\
\text { Proteobacteria) }\end{array}$ & $\begin{array}{l}\text { Hidrocarbonetos } \\
\text { metabolizados }\end{array}$ & Outros Substratos \\
\hline Thauera aromatica K172 & tolueno & $\begin{array}{l}\text { fenol, } p \text {-cresol, antranilato, } \\
\text { fenilalanina }\end{array}$ \\
\hline Thauera aromatica $\mathrm{T} 1$ & tolueno & p-cresol, 3-metilbenzoato \\
\hline Azoarcus sp. Linhagem T & tolueno, $m$-xileno & p-cresol, ciclohexanoarboxilato \\
\hline Azoarcus tolulyticus To14 & tolueno & Não relatado \\
\hline Azoarcus tolulyticus Td15 & tolueno, $m$-xileno & Não relatado \\
\hline Linhagem ToN1 & tolueno & fenol, $p$-cresol, fenilacetato \\
\hline Linhagem EbN1 & tolueno, etilbenzeno & acetofenona, fenilalanina \\
\hline Linhagem $\mathrm{PbN} 1$ & etilbenzeno & $\begin{array}{l}\text { Propilbenzeno, acetofenona, } \\
\text { propiofenona, fenilacetato, fenol }\end{array}$ \\
\hline Linhagem EB1 & etilbenzeno & acetofenona, fenilacetato, fenol \\
\hline Linhagem mXyN1 & tolueno, $m$-xileno & 3-metilbenzoato, $p$-cresol \\
\hline Linhagem T3 & tolueno & Não relatado \\
\hline Linhagem M3 & tolueno, $m$-xileno & Não relatado \\
\hline Linhagem mCyN1 & tolueno, $p$-etiltolueno & $\begin{array}{l}p \text {-cresol, } p \text {-etilbenzoato, } \\
p \text {-isopropilbenzoato }\end{array}$ \\
\hline Linhagem mCyN2* & p-cimeno & $\begin{array}{l}\text { fenilalanina, } \\
p \text {-etilbenzoato, } p \text { - } \\
\text { isopropilbenzoato }\end{array}$ \\
\hline
\end{tabular}

Fonte: Heider et al.(1999).

Dolfing et al. (1990), trabalhando com cultura pura originária do efluente de uma coluna de aqǘfero anaeróbio, demonstraram que tolueno $(26,7 \mathrm{mg} / \mathrm{L})$ foi mineralizado por cultura pura (linhagem $\mathrm{T})$, utilizando nitrato $(10 \mathrm{mM})$ como aceptor de elétrons. Nos resultados do balanço de carbono marcado, mais de 50\% da radioatividade foi recuperada como ${ }^{14} \mathrm{CO}_{2}$. Além de tolueno, a linhagem $\mathrm{T}$ foi, ainda, capaz de utilizar $m$-xileno sob condições desnitrificantes, no entanto, o microrganismo não cresceu em $o$ xileno, $p$-xileno e benzeno.

A degradação do tolueno, sob condições desnitrificantes, foi também estudada por Evans et. al. (1991). Neste estudo, a linhagem desnitrificante denominada T1, foi isolada a partir de cultura mista enriquecida, e cresceu com tolueno $(92,1 \mathrm{mg} / \mathrm{L})$ como única fonte de carbono. A linhagem T1 apresentou degradação de $1,8 \mu \mathrm{mol} \cdot \mathrm{min}^{-1} \cdot \mathrm{L}^{-1} \mathrm{e}$ foi tolerante à concentração de $276,4 \mathrm{mg} / \mathrm{L}$ de tolueno. Utilizando cromatografia gasosa e líquida, os autores demonstraram que $51 \%$ do carbono do tolueno foi mineralizado a dióxido de carbono e $29 \%$ assimilado em biomassa. A oxidação do tolueno a $\mathrm{CO}_{2}$ foi estequiometricamente acoplada à redução do nitrato. A linhagem T1 não foi capaz de 
utilizar outros hidrocarbonetos aromáticos como benzeno, etilbenzeno, $p$-xileno, $m$ xileno, e o-xileno, como única fonte de carbono para o crescimento. No entanto, $O$ xileno foi transformado em metabólito quando tolueno foi adicionado ao meio de crescimento. Posteriormente, estudos moleculares, baseados na amplificação, seqüênciamento e análise filogenética das seqüências do RNAr $16 \mathrm{~S}$, confirmaram a classificação da linhagem T1 como Thauera aromatica (Song et al.,1998).

No estudo conduzido por Fries et al. (1994), o isolamento, caracterização e distribuição de microrganismos degradadores de tolueno foi avaliado. A partir do enriquecimento realizado com diferentes inóculos, obtidos de diferentes regiões geográficas (solos de agricultura, sedimento de aqüífero, e solos contaminados), 10 isolados foram obtidos. Metodologias moleculares como o "fingerprint” produzido pela amplificação do DNA mostraram que 8 dos isolados eram diferentes. Todos os microrganismos isolados demonstraram capacidade de utilizar tolueno $(25 \mathrm{mg} / \mathrm{L})$, sob condições desnitrificantes ( $5 \mathrm{mM}$ de nitrato). Análises de seqüências parciais do RNAr $16 \mathrm{~S}$ de todos os isolados mostraram similaridade substancial às seqüências do RNAr 16S de Azoarcus sp. Os autores concluíram que a atividade e o isolamento de pelo menos um microrganismo degradador de tolueno, proveniente de diferentes regiões geográficas, sugere que microrganismos com capacidade de crescer anaerobiamente em tolueno são comumente encontrados na natureza.

Em 1995, estudos de filogenia, conduzidos por dois grupos diferentes (Anders et al.,1995; Zhou et al., 1995), reavaliaram a posição taxonômica de linhagens desnitrificantes degradadoras de tolueno.

O trabalho de Anders et al. (1995), com a linhagem denominada K172, anteriormente descrita como pertencente ao gênero Pseudomonas, subclasse $\gamma$ Proteobacteria, redefiniu a posição taxonômica desta linhagem. Através da análise de seqüências do RNAr 16S, os autores demonstraram que este microrganismo era membro da subclasse $\beta$ Proteobacteria, e que a linhagem K172, representava uma nova espécie do gênero Thauera, que foi então denominada Thauera aromatica.

Zhou et al. (1995), com o objetivo de determinar a posição filogenética de diversos microrganismos degradadores de tolueno, anteriormente descritos nos trabalhos de Dolfing et al. (1990), Evans et al. (1991) e Fries et al. (1994), sequenciaram quase que totalmente o gene RNAr 16S de cada um dos isolados e, através de análises da composição de ácidos graxos e das características bioquímicas e fisiológicas destes microrganismos, demonstraram que estes isolados estavam intimamente relacionados e 
se distinguiam das espécies de Azoarcus anteriormente descritas. Os autores propuseram, então, uma nova espécie designada como Azoarcus tolulyticus.

A degradação de etilbenzeno, sob condições desnitrificantes, foi avaliada no estudo de Rabus e Widdel. (1995). Até esta data, o crescimento anaeróbio em alquilbenzeno com cadeias laterais maiores do que aquela do tolueno não havia sido demonstrada em enriquecimentos ou em culturas puras. Neste estudo, os autores isolaram, a partir de sedimento de água doce, uma linhagem desnitrificante, linhagem EbN1, que cresceu em etilbenzeno como única fonte de carbono. Para a análise fisiológica e filogenética comparativa, outras duas linhagens desnitrificantes, ToN1 e $m \mathrm{XyN} 1$, foram isoladas da mesma amostra, em presença de tolueno e m-xileno, respectivamente. Os autores caracterizaram os isolados realizando análises das características morfológicas e fisiológicas como forma, dimensão, motilidade, conteúdo de $\mathrm{C}+\mathrm{G}$, temperatura de crescimento, $\mathrm{pH}$, tempo de crescimento e capacidade de crescimento anaeróbio em diversos compostos aromáticos. As linhagens apresentaram diferentes capacidades específicas para a degradação dos alquilbenzenos testados. Em relação à capacidade de utilização de hidrocarbonetos aromáticos, especialmente BTEX, além de etilbenzeno, a linhagem Eb1 utilizou tolueno. A linhagem ToN1 usou apenas tolueno, enquanto que a linhagem $\mathrm{mXyN1}$ utilizou tanto $m$-xileno, como tolueno. $\mathrm{O}$ seqüênciamento do RNAr $16 \mathrm{~S}$ das linhagens isoladas revelou relação destes microrganismos com o grupo filogenético que compreende Thauera selenatis e espécies do gênero Azoarcus. Estes relatos estão de acordo com análises filogenéticas de outros estudos que demonstraram a utilização de tolueno e $m$-xileno por microrganismos desnitrificantes.

Até 1996, sabia-se que diversos microrganismos eram capazes de catalisar a oxidação de hidrocarbonetos aromáticos na ausência de oxigênio molecular, entretanto, os mecanismos bioquímicos das reações enzimáticas não haviam sido desvendados. Experimentos com bactéria desnitrificante, linhagem EB1, foram conduzidos para examinar os primeiros passos da oxidação anaeróbia do etilbenzeno. Ball et al. (1996) demonstraram que células da linhagem EB1 mineralizaram etilbenzeno $(28,8 \mathrm{mg} / \mathrm{L})$ a $\mathrm{CO}_{2}$, sob condições desnitrificantes $(3.3 \mathrm{mM}$ de nitrato), como demonstrado pela conversão de $69 \%$ de $\left[\mathrm{C}^{14}\right]$ etilbenzeno a ${ }^{14} \mathrm{CO}_{2}$. Durante a conversão de etilbenzeno, observou-se a formação e o consumo de 1-feniletanol, acetofano e um intermediário desconhecido, que foi sugerido como sendo benzoilacetato. Os experimentos com células em suspensão usando $\mathrm{H}_{2}{ }^{18} \mathrm{O}$ demonstraram que a hidroxila do primeiro produto 
da oxidação anóxica do etilbenzeno, 1-feniletanol, foi derivado da água. Com estes resultados, os autores propuseram uma via anaeróbia da mineralização do etilbenzeno.

No estudo de Hess et al. (1997) foram obtidas, após 3,5 anos de remediação, amostras de aqüífero contaminado com óleo diesel, biorremediado in situ pela injeção de oxidantes $\left(\mathrm{O}_{2} \mathrm{e} \mathrm{NO}_{3}{ }^{-}\right)$e nutrientes. As amostras foram utilizadas para isolar bactérias desnitrificantes capazes de utilizar hidrocarbonetos aromáticos. Deste estudo, cinco linhagens $\left(T_{2}, T_{3} T_{4}, T_{6}\right.$ e $\left.T_{10}\right)$ de bactérias capazes de crescer em tolueno $(17,5 \mathrm{mg} / \mathrm{L}) \mathrm{e}$ nove linhagens $\left(\mathrm{M}_{3}\right.$, a $\mathrm{M}_{7}$ e $\mathrm{M}_{9}$ a $\left.\mathrm{M}_{12}\right)$ que cresciam tanto em tolueno, como em $\mathrm{m}$ xileno $(17,0 \mathrm{mg} / \mathrm{L})$ foram isoladas, em presença de $5 \mathrm{mM}$ de nitrato. Os estudos incluíram a caracterização molecular dos isolados por análises de seqüências comparativas do RNAr 16S, e o uso de sondas específicas para quantificar os isolados pela hibridização in situ.

Semelhantemente, Song et al. (1999) realizaram a caracterização taxonômica de 21 linhagens, isoladas de diferentes regiões geográficas capazes de degradar tolueno sob condições desnitrificantes. Os estudos foram realizados com base nas características gerais da morfologia e fisiologia dos microrganismos, bem como na análise de ácidos graxos, composição de base de DNA, seqüência de RNAr, padrão de proteínas da célula, padrão de fragmentação enzimática do genoma e métodos de hibridização. As linhagens foram subdivididas em cinco grupos nos quais seus representantes puderam ser considerados como pertencentes à espécie Azoarcus tolulyticus (grupo I), variantes de Azoarcus tolulyticus (grupo II), Azoarcus toluclasticus (grupo III), variantes de Azoarcus toluclasticus (grupo IV) e Azoarcus toluvorans (grupo V).

Até 1999, a biodegradação do benzeno ligada à redução do sulfato (Lovley et al., 1995), do ferro (Lovley et al., 1996), e sob condições metanogênicas (Kazumi et al., 1997), já havia sido confirmada. No entanto, não havia nenhum relato que confirmasse a degradação do benzeno, associado à redução do nitrato. Em 1999, um estudo com cultura enriquecida, desenvolvida a partir de microcosmos de solos e água subterrânea, buscaram confirmar a associação entre a biodegradação de benzeno e a redução do nitrato (Burland e Edwards, 1999). A degradação do benzeno (11,7 mg/L) ocorreu concomitantemente com a redução do nitrato $(5 \mathrm{mM})$ a taxa constante de 10 moles de nitrato por mol de benzeno degradado, e foi associada ao crescimento celular. Nos experimentos realizados com $\left[\mathrm{C}^{14}\right]$ benzeno, 92 a $95 \%$ do carbono marcado foi recuperado como $\mathrm{CO}_{2}$. Embora a degradação de benzeno tenha sido confirmada neste 
estudo, a identificação dos microrganismos responsáveis pela biodegradação deste composto não foi realizada.

Shimoda et al. (2000) isolaram e caracterizaram duas espécies desnitrificantes degradadoras de fenol e outros compostos aromáticos, a partir de cultura enriquecida durante 3 anos. A espécie denominada CC-1 apresentou morfologia de bacilo e foi classificada como pertencente ao gênero Azoarcus. O outro isolado apresentou células espirais e filogeneticamente associadas às espécies pertencentes ao gênero Magnetospirillum, um membro da subclasse $\alpha$ Proteobacteria.

Em 2001, Coates e colaboradores relataram duas espécies de Dechloromonas, nomeadas RCB e JJ, capazes mineralizar vários compostos monoaromáticos, incluindo o benzeno, a $\mathrm{CO}_{2}$, na ausência de oxigênio, mas com nitrato como aceptor de elétrons. Neste estudo os autores relatam o potencial das espécies isoladas e a aplicabilidade destes microrganismos para o tratamento de ambientes contaminados.

Recentemente (Shinoda et al., 2004), uma nova linhagem de Thauera sp., denominada DNT-1, cresceu em tolueno como única fonte de carbono e energia, sob condições aeróbias e desnitrificantes. Neste estudo, as observações bioquímicas indicaram que a degradação inicial de tolueno ocorria através de uma via mediada pela dioxigenase e a via benzilsuccinase, sob condições aeróbias e desnitrificantes, respectivamente. Os autores realizaram a clonagem dos genes responsáveis pelas sínteses da dioxigenase e benzilsuccinase, a partir do DNA da espécie DNT-1, e verificaram que os resultados obtidos com as técnicas de biologia molecular (Northern Blot e PCR em tempo real - real time quantitative reverse transcriptase PCR) que estes genes foram induzidos pela presença do tolueno. Os autores concluíram que a espécie DNT-1 modula a expressão de diferentes vias de degradação de tolueno de acordo com a disponibilidade de oxigênio no ambiente.

Em 2005, um estudo sobre a organização dos genes envolvidos nas vias metabólicas da degradação de etilbenzeno e tolueno foi realizado por Kühner et al. (2005). Neste estudo a espécie desnitrificante, EbN1, capaz de degradar estes dois compostos anaerobiamente foi utilizada para a análise da expressão global e regulação dos genes envolvidos nessas vias de degradação. 


\subsection{Estudos com culturas enriquecidas}

\subsection{1 - Estudos em microcosmos e colunas}

A literatura sobre a degradação anaeróbia de BTEX está baseada em estudos de biorremediação in situ em áreas contaminadas, simulações de contaminação de lençol freático em colunas, demonstração da biodegradabilidade em microcosmos, e estudos metabólicos e genéticos usando culturas puras. Todos estes estudos deixam claro que a biodegradação de hidrocarbonetos aromáticos sob condições anaeróbias, não só é possível, mas também pode ser uma alternativa prática para outras opções de tratamento.

A maior utilidade dos estudos de campo é que eles demonstram o potencial para a biorremediação sob as condições reais do meio ambiente em estudo. No entanto, é freqüentemente impossível controlar adequadamente uma área, sem que fatores, como perda abiótica, sejam considerados. Para resolver este problema, pesquisadores utilizam colunas preenchidas com sedimentos ou amostras de aqüíferos como modelos representativos de condições in situ. A maioria dos estudos utilizando colunas tem avaliado a estimulação da degradação sob condições desnitrificantes. Muito do que se conhece a respeito da degradação anaeróbia de hidrocarbonetos aromáticos foi verificado em estudos com microcosmos. Microcosmos são construídos obtendo-se amostras provenientes de uma área de estudo, as quais são transferidas para frascos selados, onde as condições podem ser controladas e a atividade monitorada. No entanto, tanto os estudos em colunas, quanto em microcosmos são, geralmente, o primeiro passo para demonstrar que microrganismos são capazes de realizar determinada transformação. Phelps e Young. (2001) apresentaram uma revisão dos estudos realizados sobre biorremediação in situ, em coluna e microcosmos (Quadro 2). 
Quadro 2 - Revisão da literatura sobre degradação anaeróbia de BTEX com culturas puras, microcosmos e colunas

\begin{tabular}{|c|c|c|c|c|c|c|}
\hline 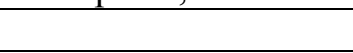 & Benzeno & Tolueno & Etilbenzeno & $p$-xileno & $m$-xileno & $O$-xileno \\
\hline \multicolumn{7}{|l|}{ Cultura pura } \\
\hline Ball et al. (1996) & & & $\mathrm{N}$ & & & \\
\hline Beller et al. (1996) & & $\mathrm{S}$ & & & & \\
\hline Dolfing et al.(1990) & & $\mathrm{N}$ & & & $\mathrm{N}$ & \\
\hline Evans et al. (1991) & & $\mathrm{N}$ & & & & \\
\hline Fries et al. (1994) & & $\mathrm{N}$ & & & $\mathrm{N}$ & \\
\hline Harms et al. (1999) & & $\mathrm{S}$ & & & $\mathrm{S}$ & $\mathrm{S}$ \\
\hline Hess et al. (1997) & & $\mathrm{N}$ & & & $\mathrm{N}$ & \\
\hline $\begin{array}{l}\text { Lovley } \\
\text { e Lonergan. (1990) }\end{array}$ & & $\mathrm{F}$ & & & & \\
\hline Rabus et al. (1993) & & $\mathrm{S}$ & & & & \\
\hline $\begin{array}{lll}\begin{array}{l}\text { Rabus } \\
(1995)\end{array} & \text { e } & \text { Widdel. } \\
\end{array}$ & & $\mathrm{N}$ & $\mathrm{N}$ & & $\mathrm{N}$ & \\
\hline Schocher et al. (1991) & & $\mathrm{N}$ & & & & \\
\hline \multicolumn{7}{|l|}{ Microcosmos } \\
\hline Ball e Reinhard. (1996) & & $\mathrm{N}, \mathrm{S}$ & $\mathrm{N}$ & $\mathrm{N}, \mathrm{S}$ & $\mathrm{N}, \mathrm{S}$ & $\mathrm{N}$ \\
\hline Beller et al. (1992) & & $\mathrm{S}$ & & & & \\
\hline Bregnard et al. (1996) & & $\mathrm{N}$ & & $\mathrm{N}$ & $\mathrm{N}$ & $\mathrm{N}$ \\
\hline $\begin{array}{l}\text { Edwards e Grbic-Galic. } \\
\text { (1994) }\end{array}$ & & $\mathrm{C}$ & & & & $\mathrm{C}$ \\
\hline Edwards et al. (1992) & & $\mathrm{S}$ & & $\mathrm{S}$ & $\mathrm{S}$ & $\mathrm{S}$ \\
\hline $\begin{array}{l}\text { Grbic-Galic e Vogel. } \\
\text { (1987) }\end{array}$ & $\mathrm{C}$ & $\mathrm{C}$ & & & & \\
\hline Haner et al. (1995) & & $\mathrm{N}$ & & $\mathrm{N}$ & $\mathrm{N}$ & \\
\hline Hutchins et al. (1991) & & $\mathrm{N}$ & $\mathrm{N}$ & $\mathrm{N}$ & $\mathrm{N}$ & \\
\hline Kao e Borden. (1997) & & $\mathrm{N}$ & $\mathrm{N}$ & & $\mathrm{N}$ & $\mathrm{N}$ \\
\hline Kazumi et al. (1997) & $\mathrm{C}, \mathrm{S}, \mathrm{F}$ & & & & & \\
\hline Kazumi et al. (1998) & $\mathrm{C}, \mathrm{S}, \mathrm{F}$ & $\mathrm{N}, \mathrm{S}, \mathrm{C}, \mathrm{F}$ & & $\mathrm{N}, \mathrm{S}, \mathrm{F}$ & $\mathrm{N}, \mathrm{S}, \mathrm{C}, \mathrm{F}$ & $\mathrm{C}, \mathrm{F}, \mathrm{S}$ \\
\hline Langehoff et al. (1997) & & $\mathrm{Mn}$ & & & & \\
\hline Lovley et al. (1995) & $\mathrm{S}$ & & & & & \\
\hline Lovley et al. 1994 & $\mathrm{~F}$ & & & & & \\
\hline Major et al. 1998 & $\mathrm{~N}$ & & & & & \\
\hline Phelps e Young, 1999 & $\mathrm{~S}$ & $\mathrm{~N}, \mathrm{~S}, \mathrm{C}, \mathrm{F}$ & $\mathrm{N}, \mathrm{S}, \mathrm{C}, \mathrm{F}$ & $\mathrm{N}, \mathrm{S}, \mathrm{F}$ & $\mathrm{N}, \mathrm{S}, \mathrm{F}$ & $\mathrm{N}, \mathrm{S}, \mathrm{F}$ \\
\hline Phelps et al. (1996) & $\mathrm{S}$ & & & & & \\
\hline Rabus et al. (1996) & & $\mathrm{S}$ & & & $\mathrm{S}$ & $\mathrm{S}$ \\
\hline Wilson et al. (1996) & $\mathrm{C}$ & $\mathrm{C}$ & $\mathrm{C}$ & & & $\mathrm{C}$ \\
\hline \multicolumn{7}{|l|}{ Colunas } \\
\hline Anid et al. (1993) & $\mathrm{N}$ & $\mathrm{N}$ & $\mathrm{N}$ & $\mathrm{N}$ & $\mathrm{N}$ & $\mathrm{N}$ \\
\hline Haag et al. (1991) & & $\mathrm{S}$ & & $\mathrm{S}$ & & \\
\hline Hutchins et al. (1992) & & $\mathrm{N}$ & $\mathrm{N}$ & $\mathrm{N}$ & $\mathrm{N}$ & \\
\hline Kuhn et al. (1985) & & & & $\mathrm{N}$ & $\mathrm{N}$ & $\mathrm{N}$ \\
\hline Kuhn et al. (1988) & & $\mathrm{N}$ & & & $\mathrm{N}$ & \\
\hline Langehoff et al. (1996) & & $\begin{array}{c}\text { N.S,C,F, } \\
\mathrm{Mn}\end{array}$ & & & & \\
\hline $\begin{array}{lll}\begin{array}{l}\text { Master } \\
(1996)\end{array} & \text { e } & \text { Kosson, } \\
\end{array}$ & & $\mathrm{N}$ & & & & \\
\hline Ramanand et al. (1995) & & $\mathrm{N}$ & & & & \\
\hline Zeyer et al. (1986) & & $\mathrm{N}$ & $\mathrm{N}$ & & $\mathrm{N}$ & \\
\hline \multicolumn{7}{|l|}{ In situ } \\
\hline Acton e Barker, 1992 & & $\mathrm{C}$ & $\mathrm{C}$ & & $\mathrm{C}$ & $\mathrm{C}$ \\
\hline Barbaro et al. (1992) & & $\mathrm{C}, \mathrm{N}$ & & & & \\
\hline Hutchins et al. (1991) & & $\mathrm{N}$ & $\mathrm{N}$ & $\mathrm{N}$ & $\mathrm{N}$ & \\
\hline Reinhard et al. (1997) & & $\mathrm{N}, \mathrm{S}$ & $\mathrm{N}, \mathrm{S}$ & $\mathrm{N}, \mathrm{S}$ & $\mathrm{N}, \mathrm{S}$ & $\mathrm{N}, \mathrm{S}$ \\
\hline
\end{tabular}

Fonte: Phelps e Young. (2001). N - desnitrificante; S - sulfetogênica; C - metanogênica; F redução de ferro; redução de $\mathrm{Mn}$ 


\subsubsection{Estudos em biorreatores}

Os bioreatores são sistemas que podem apresentar diversas configurações e arranjos. Estes sistemas são compostos por microrganismos e possivelmente outros agentes catalíticos, que agem cooperativamente com os microrganismos. Para estimular o crescimento destes organismos, nutrientes são adicionados ao meio. Nestes sistemas, a biomassa pode crescer em suspensão ou aderidos a uma matriz.

De acordo com Cohen. (2001), na degradação de poluentes, os reatores biológicos com biomassa imobilizada apresentam inúmeras vantagens frente aos reatores operados com biomassa suspensa devido à elevada concentração de biomassa, elevada atividade metabólica atribuída à alta concentração de nutrientes aderidos ao biofilme e às diferentes interações entre espécies microbianas, e resistência à toxicidade, principalmente, devido ao efeito protetor da matriz extracelular (barreira de difusão) que pode reduzir a concentração de tóxico no biofilme.

Em 1997, a configuração do reator anaeróbio horizontal de leito fixo, com biomassa imobilizada em matriz de poliuretano, foi estuda e proposta por Zaiat et al. (1997). Os autores verificaram que esta configuração apresentava bom desempenho com grande estabilidade do processo devido à capacidade de trabalhar com elevados tempos de retenção celular quando operados com baixos tempos de detenção hidráulica. A partir deste estudo, outros trabalhos foram realizados nesta configuração de reator, especialmente relacionados com o tratamento de compostos tóxicos como pentaclorofenol (Damianovic, 1997), fenol (Bolaños et al., 2001), formaldeído (Oliveira et al., 2004) e BTEX (Nardi, 2002; Ribeiro, 2005; Cattony, 2005). Revisão mais aprofundada destes e outros trabalhos com biorreatores pode ser encontrada no estudo de Ribeiro. (2005) e está sumarizada no quadro 3 
Quadro 3- Estudos realizados com diferentes sistemas no tratamento de compostos tóxicos.

\begin{tabular}{|c|c|c|c|}
\hline Sistema de tratamento & Composto tóxico tratado & Resultado obtido & Referência \\
\hline $\begin{array}{l}\text { Filtro } \\
\text { biológico, } \\
\text { Biodisco e Reator de } \\
\text { filme fixo e fluxo } \\
\text { ascendente }\end{array}$ & $\begin{array}{l}\text { Hidrocarbonetos } \\
\text { policíclicos, BTEX e } \\
\text { fenólicos }\end{array}$ & $\begin{array}{l}\text { Reator com biomassa imobilizada apresentou maior } \\
\text { eficiência de remoção dos compostos tóxicos }\end{array}$ & $\begin{array}{l}\text { Van der Hoek et al., } \\
1989\end{array}$ \\
\hline Lagoas aeradas & $\begin{array}{ll}\text { Hidrocarbonetos } & \text { aromáticos } \\
\text { policíclicos e BTEX } & \end{array}$ & $\begin{array}{l}98 \% \text { para benzeno, } 94 \% \text { para tolueno e } 99 \% \text { para } \\
\text { etilbenzeno. }\end{array}$ & Vail, 1991 \\
\hline Bateladas seqüenciais & $\begin{array}{l}\text { Hidrocarbonetos } r \text { aromáticos } \\
\text { provenientes de sítio contaminado } \\
\text { com combustível de avião }\end{array}$ & Remoção quase completa dos BTEX & Yocum et al., 1995 \\
\hline Batelada e contínuo & Tolueno & $\begin{array}{l}\text { Remoção de completa de tolueno (batelada). Em reator } \\
\text { contínuo a concentração de tolueno permaneceu abaixo } \\
\text { de } 1 \mathrm{mg} / \mathrm{L} \text {, para concnetração afluente de } 150 \mathrm{mg} / \mathrm{L}\end{array}$ & $\begin{array}{l}\text { Chaudhuri e Wiesmann, } \\
1996\end{array}$ \\
\hline RAHLF & Pentaclorofenol & Eficiente remoção de pentaclorofenol & Damianovic, 1997 \\
\hline Bateladas seqüenciais & $\begin{array}{l}\text { Hidrocarbonetos } \\
\text { provenientes de efluentes de sistema } \\
\text { de limpeza de tanques de } \\
\text { armazenamento de compostos } \\
\text { químicos }\end{array}$ & 99\% de remoção de BTEX & Zilverentant, 1997 \\
\hline Biofiltro aerado & $\begin{array}{l}\text { Água de lavagem de } \\
\text { contaminados por gasolina }\end{array}$ & Eficiente degradação de BTEX & Wright et al., 1997 \\
\hline Reator híbrido & Efluente contendo BTEX & Remoção de BTEX acima de $90 \%$ & Yeom e Yoo, 1999 \\
\hline
\end{tabular}


Continuação do quadro 3

\begin{tabular}{|c|c|c|c|}
\hline Reator de leito fixo & BTEX & $\begin{array}{l}\text { Velocidades de consumo de BTEX pelas células } \\
\text { imobilizadas de } 9 \text { a } 75 \text { vezes altas do que as células } \\
\text { livres. }\end{array}$ & Shim e Yang, 1999 \\
\hline $\begin{array}{l}\text { Reator aeróbio } \\
\text { fluidizado }\end{array}$ & Efluente contendo $50 \mathrm{mg} / \mathrm{L}$ de BTEX & $\begin{array}{l}\text { Os processos de adsorção e biodegradação ocorriam } \\
\text { simultaneamente otimizando a transferência de BTEX } \\
\text { para as células }\end{array}$ & Mason et al., 2000 \\
\hline Bateladas seqüenciais & Compostos aromáticos (BTX) & $\begin{array}{l}\text { Degradação de tolueno e } m \text {-xileno em presença de } \\
\text { nitrato e degradação de benzeno, } o \text {-xileno e } p \text {-xileno em } \\
\text { condições microaerofílicas. }\end{array}$ & Ma e Love, 2001 \\
\hline Biofiltro aeróbio & BTEX & $\begin{array}{l}\text { Eficiência de remoção etilbenzeno }>\text { benzeno }>o \text {-xileno } \\
>m \text {-xileno }>p \text {-xileno }\end{array}$ & Du Plessis et al., 2001 \\
\hline RAHLF & Fenol & $\begin{array}{l}\text { remoção na ordem de } 99 \% \text { para concentrações de fenol } \\
\text { que variaram de } 50 \text { a } 1200 \mathrm{mg} / \mathrm{L}\end{array}$ & Bolãnos, 2001 \\
\hline RAHLF & Formaldeído & Eficiência de remoção de formaldeído de 99,7\% & Oliveira, 2001 \\
\hline RAHLF & $\begin{array}{l}\text { Água residuária composta de solução } \\
\text { etanólica e BTEX }\end{array}$ & $\begin{array}{l}\text { Concentrações de BTEX no efluente menores que } \\
0,1 \mathrm{mg} / \mathrm{L} \text {, }\end{array}$ & Nardi, 2002 \\
\hline $\begin{array}{l}\text { Reator de leito fixo } \\
\text { submerso } \\
\text { e reator fluidificado }\end{array}$ & $\begin{array}{l}\text { Águas subterrâneas contaminadas por } \\
\text { BTEX }\end{array}$ & Remoção de 99\% de benzeno, tolueno e xilenos. & Guerin, 2002 \\
\hline $\begin{array}{ll}\text { Reator aeróbio } \\
\text { Fluidificado }\end{array}$ & $\begin{array}{l}\text { Águas subterrâneas contaminadas por } \\
\text { BTEX }\end{array}$ & Remoção completa de BTEX & Pruden et al., 2003 \\
\hline
\end{tabular}

Fonte: Ribeiro 2005 
Mais recentemente, outros três estudos foram realizados com RAHLF no tratamento de BTEX.

Os estudos desenvolvidos por Ribeiro. (2005) demonstraram a viabilidade técnica da aplicação do RAHLF sob condições metanogênicas, operando com TDH de 16 horas. O autor verificou remoção de $99 \%$ da matéria orgânica e em torno de $95 \%$ dos BTX, os quais foram verificadas as seguintes concentrações no efluente (benzeno $0,62 \pm 0,41 \mathrm{mg} / \mathrm{L}$; tolueno - 0,71 $\pm 0,46 \mathrm{mg} / \mathrm{L}$; meta-xileno - 0,28 $\pm 0,19 \mathrm{mg} / \mathrm{L}) . \mathrm{O}$ autor também verificou que os valores estimados para as constantes cinéticas, considerando modelo cinético de primeira ordem, com residual para a remoção dos BTX, foram muitos superiores, cerca de cem vezes maiores do que os encontrados na literatura. Neste estudo, outro reator, operado sob condições desnitrificantes, apresentou remoção quase total de nitrato e BTX, praticamente, no primeiro trecho do reator, o que caracterizou o reator como um sistema misto, onde o metabolismo desnitrificante ocorria no primeiro seguimento do mesmo, enquanto que, no restante do reator, o metabolismo era metanogênico.

Cattony. (2005) estudou a remoção de etanol, benzeno e tolueno em reator anaeróbio horizontal de leito fixo na presença de sulfato. Os reatores foram inoculados com lodo de reator UASB tratando águas residuárias provenientes de abatedouro de aves e operados com tempo de detenção hidráulica de $12 \mathrm{~h}$. Tolueno e benzeno foram adicionados, separadamente nos reatores, em concentrações iniciais de 2,0 mg.1 ${ }^{-1}$, seguidas de aumentos que variaram até valores finais de 9 e $10 \mathrm{mg} / \mathrm{L}$, para tolueno e benzeno, respectivamente. Sulfato foi adicionado em concentrações de 91 e $550 \mathrm{mg} / \mathrm{L}$ de sulfato ferroso e sulfato de sódio, respectivamente, para promoção de ambiente sulfetogênico. A eficiência na remoção da matéria orgânica, que variou de $170 \mathrm{mg} / \mathrm{L} \mathrm{a}$ $960 \mathrm{mg} / \mathrm{L}$ nos dois reatores, foi próxima a 90\%, com taxa máxima de degradação de tolueno de $0,06 \mathrm{mg}_{\text {tolueno. }} \mathrm{mg}^{-1} \mathrm{ssv} \cdot \mathrm{d}^{-1}$, e $0,07 \mathrm{mg}_{\text {benzeno }} \cdot \mathrm{mg}^{-1}{ }_{\mathrm{ssv}} \cdot \mathrm{d}^{-1}$, para benzeno. A redução de sulfato foi de aproximadamente $99,9 \%$ em todas as condições nutricionais nos dois reatores.

Fernandes. (2005) utilizando diferentes tipos de biomassa avaliou a influência do inóculo e de aceptores de elétrons no processo de degradação anaeróbia de BTX. Os resultados obtidos comprovaram que a origem do inóculo foi fundamental na degradação anaeróbia de BTX, pois os inóculos apresentaram diferentes períodos de adaptação e porcentagens de degradação destes compostos. A autora concluiu que o inóculo proveniente de reator tratando água residuária de abatedouro de aves apresentou 
maior eficiência de remoção de BTEX que foi de 90\%, comparada com eficiências de $57 \%$ e $83 \%$ para biomassa proveniente de um reator, RAHLF tratando BTEX e, inóculo proveniente de estação de tratamento de esgoto, respectivamente. Neste estudo, a autora também verificou que a adição de Fe (III), no reator sob condições sulfetogênicas favoreceu a degradação dos BTX.

\subsection{Considerações finais}

Todos estes estudos consolidam a possibilidade do tratamento de compostos como os BTEX. Entre os biorreatores citados na revisão da literatura, o reator anaeróbio horizontal de leito fixo tem-se consolidado como sistema viável no tratamento de compostos tóxicos, tanto no que diz respeito ao bom desempenho do reator, quanto à estabilidade alcançada no processo, mesmo quando o sistema é operado com altas cargas orgânicas. Sob o ponto de vista econômico, o RAHLF apresenta a vantagem de ter baixo custo operacional, quando comparado a outras tecnologias utilizadas para biorremediação. Nos últimos anos, os estudos realizados com RAHLF, no Laboratório de Processos Biológicos da Escola de Engenharia de São Carlos da Universidade de São Paulo, vêm aprimorando este sistema no sentido de viabilizar sua aplicação, em escala real, para o tratamento de efluentes contaminados por compostos tóxicos. No entanto, as informações a respeito da biomassa envolvida no processo de remoção destes tóxicos são, ainda, escassas. Até o presente momento, todas as informações sobre os microrganismos presentes nos biofilmes destes reatores, ajudaram no melhor entendimento deste sistema, no que diz respeito: (1) morfologias predominantes, (2) esclarecimento sobre a dinâmica destas populações frente aos compostos tóxicos (3), e a composição deste biofilme dentro dos Domínios Bacteria e Archaea. Todos estes estudos foram realizados utilizando-se culturas mistas, em que consórcios complexos estiveram envolvidos. Devido ao alto grau de complexidade destes consórcios, nenhuma informação pôde ser obtida sobre a biologia das células, e sobre quais eram os microrganismos envolvidos diretamente com a degradação dos compostos tóxicos.

A identificação dos microrganismos do biofilme é de suma importância para o aprimoramento de reatores. Conhecendo-se estes microrganismos, pode-se obter importantes informações a respeito dos aspectos ecológicos, fisiológicos e genéticos ligados a biodegradação, que vão auxiliar para o alcance de melhores eficiências dos 
processos de remoção nos reatores. Neste contexto, conhecendo-se, por exemplo, o tempo de geração da cultura (inóculo), pode-se prever com que rapidez ou lentidão o biofilme se formará no reator, ou, ainda, o quanto de biomassa será formada, atentando para possível entupimento do sistema, entre outros aspectos. Ainda sobre fisiologia, a caracterização nutricional da cultura, poderá informar sobre as principais fontes orgânicas utilizadas pelas células, e sobre a versatilidade metabólica dos microrganismos em crescer em diferentes condições (desnitrificantes, sulfetogênicas, fermentativas), proporcionando, assim, melhor escolha dos substratos e aceptores de elétrons a serem utilizados. Neste sentido, o presente estudo vem colaborar, de forma inédita, dentro dos estudos realizados com RAHLF, para o melhor entendimento de aspectos ligados a biologia de uma cultura desnitrificante envolvida com o processo de remoção de benzeno, tolueno, etilbenzeno e xilenos, neste tipo de reator. 


\section{MATERIAL E MÉTODOS}

Este trabalho foi realizado em duas etapas distintas. Na primeira etapa, os ensaios foram realizados em reatores em batelada e na segunda, em reator anaeróbio horizontal de leito fixo (RAHLF).

Nos ensaios em batelada (Figura 1), dois meios de cultivos (meio Zinder e meio Dolfing) foram avaliados para determinar a melhor condição nutricional para o desenvolvimento de microrganismos desnitrificantes. Uma vez obtida a melhor condição nutricional, as metodologias de purificação e isolamento em placa de Petri foram realizadas com o objetivo de obter culturas purificadas e, posteriormente, avaliar a capacidade de remoção de BTEX por estas culturas.

Testes para avaliar a degradação dos hidrocarbonetos foram realizados em reatores em batelada. No entanto, os resultados obtidos não foram conclusivos. Desse modo, optou-se em realizar a segunda etapa do trabalho experimental em reatores preenchidos com material suporte e crescimento celular aderido. Assim, a segunda etapa deste trabalho, teve como objetivo avaliar a remoção de BTEX, em reator anaeróbio horizontal de leito fixo, pelas culturas purificadas na primeira etapa.

Foram utilizados dois RAHLFs. No reator denominado RAHLF1, utilizou-se como inóculo para formar o biofilme, a cultura purificada em presença de benzeno. Neste reator, o meio suporte (espumas de poliuretano) foi mantido durante todo o período de operação do reator. Esta estratégia teve como objetivo avaliar a capacidade do biofilme em remover BTEX, quando continuamente submetido a esses compostos. Inicialmente, o reator foi alimentado com benzeno, em diferentes concentrações. Após este período, o reator foi alimentado, separadamente, com tolueno, m-xileno, etilbenzeno, e com BTEX (todos os hidrocarbonetos presentes em única solução). Os perfis espaciais foram realizados conforme esquematizado na Figura 2.

No reator denominado RAHLF2, utilizou-se como inóculo para forma o biofilme, cultura purificada em presença de etilbenzeno. Neste reator, o meio suporte foi removido todas as vezes que novo hidrocarboneto era utilizado na alimentação. Esta estratégia teve como objetivo avaliar a capacidade do biofilme em remover os 
hidrocarbonetos, independentemente da adaptação prévia do mesmo, a outros compostos. O reator foi alimentado, separadamente, com benzeno, tolueno, etilbenzeno, $o$-xileno, $m$-xileno, $p$-xileno e com BTEX (Figura 3). Os perfis espaciais dos reatores e RAHLF2 foram realizados todas as vezes que diferentes concentrações foram utilizadas na alimentação dos reatores, conforme esquematizado nas Figuras 2 e 3.

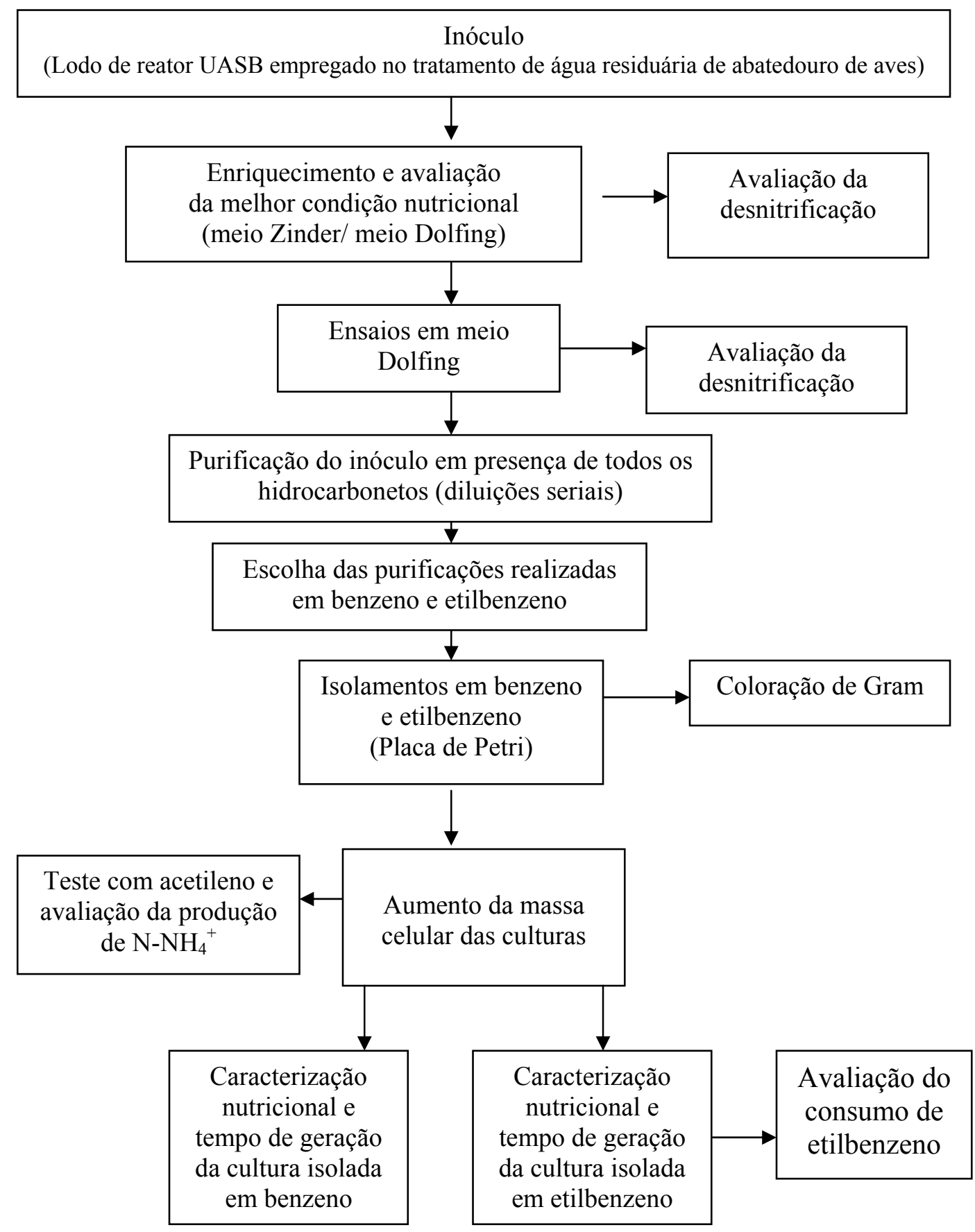

OBS: exames microscópicos foram realizados em todos os ensaios

Figura 1 - Fluxograma da primeira etapa experimental dos ensaios em reatores em batelada. 


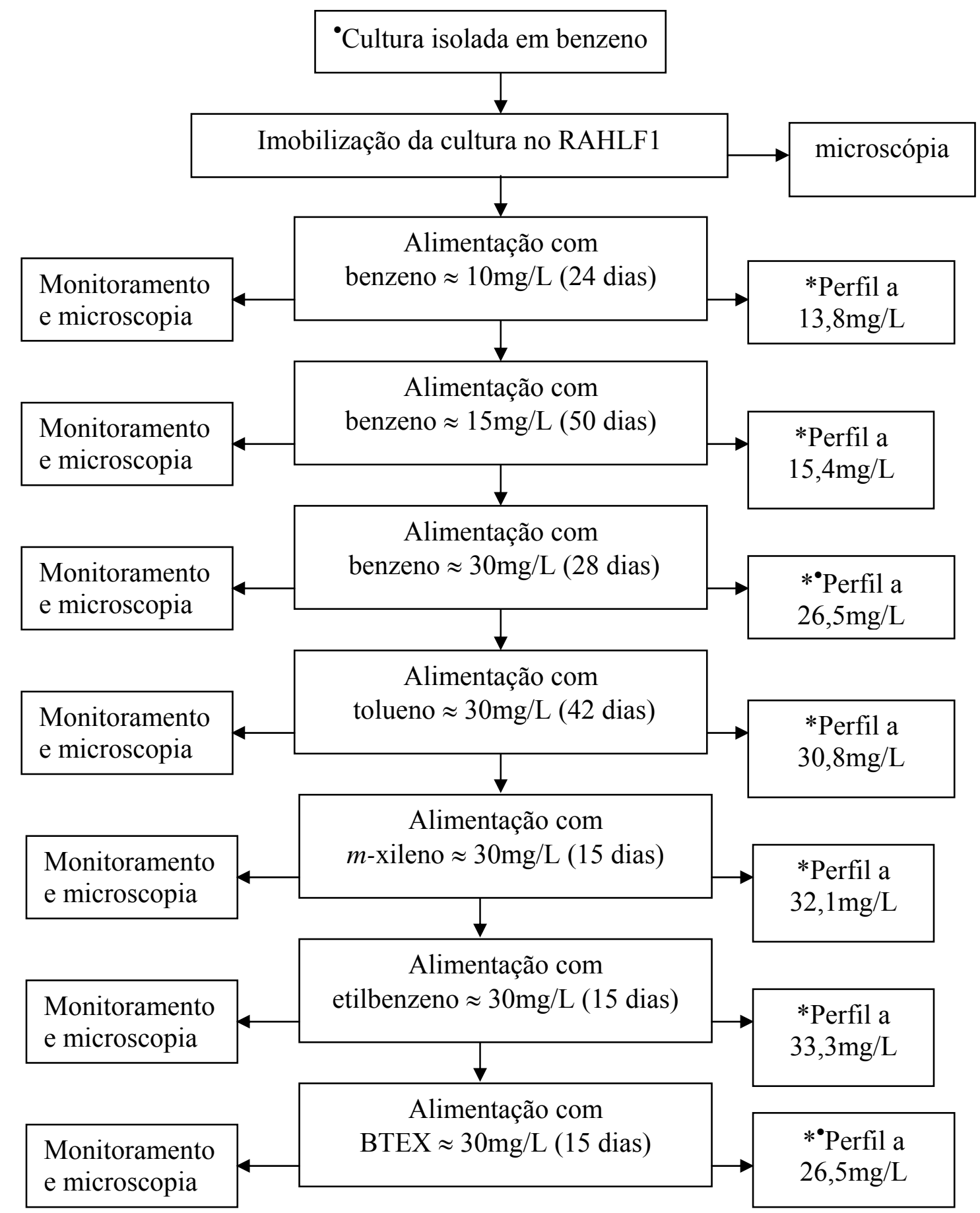

* Obtenção de amostras para serem avaliadas pelas técnicas moleculares (PCR, DGGE).

- Amostras submetidas ao sequenciamento

OBS: As análises foram baseadas nas concentrações obtidas dos perfis ocorridos ao final do período de alimentação do reator com o hidrocarboneto específico.

Figura 2 - Fluxograma das etapas experimentais realizadas no RAHLF1 


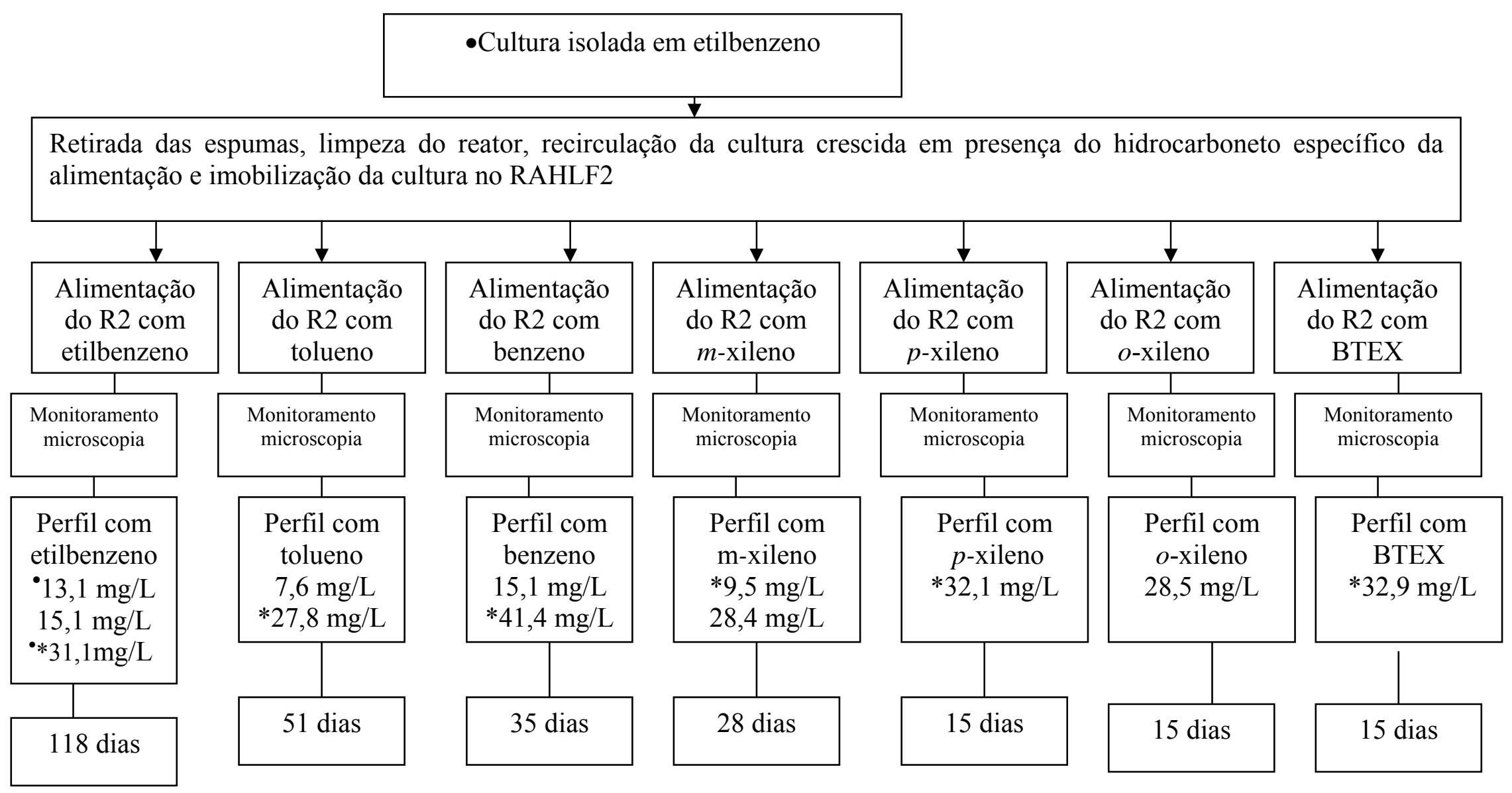

*Obtenção de amostras para serem avaliadas pelas metodologias moleculares (PCR, DGGE).

- Amostras submetidas ao sequenciamento

OBS: As análises foram baseadas nas concentrações obtidas dos perfis ocorridos ao final do período de alimentação do reator com o hidrocarboneto específico.

Figura 3 - Fluxograma das etapas dos ensaios realizados no reator RAHLF2. 
Todo material utilizado, durante todas as etapas experimentais, foi previamente esterilizado em autoclave.

Todas as curvas de calibração utilizadas nas análises estão apresentadas no Apêndice A

\subsection{Inóculo}

A biomassa utilizada como inóculo neste trabalho foi obtida de reator anaeróbio de manta de lodo e escoamento ascendente, instalado em abatedouro de aves no município de Tietê (SP). O lodo foi colocado em peneira e lavado com água quimicamente pura, para retirar o excesso de nitrogênio amoniacal. Posteriormente, o lodo foi homogeneizado e desintegrado em liquidificador doméstico, e submetido a atmosfera de $\mathrm{N}_{2}(100 \%)$ durante 10 minutos, antes de sua utilização.

\subsection{Ensaios de Enriquecimento}

Os ensaios de enriquecimentos foram realizados utilizando-se os meios de cultivos descritos por Zinder et al. (1984) e Dolfing et al. (1990) acrescidos de fontes de carbono (acetato e etanol), sendo o aceptor de elétrons fornecido em solução de nitrato de sódio. As composições das soluções utilizadas no enriquecimento estão apresentadas nas Tabelas 3 a 7.

O enriquecimento foi realizado em frascos de Duran (2L), considerando 1 litro de meio de cultivo em volume e $8 \%$ (v/v) de inóculo, conforme representado nas Tabelas 8 e 9 . O headspace foi mantido em 50\%, com atmosfera de $\mathrm{N}_{2}(100 \%)$ e $\mathrm{N}_{2} / \mathrm{CO}_{2}(70 / 30 \%)$ para os meios Dolfing e Zinder, respectivamente. A troca da atmosfera gasosa foi realizada com pipetas estéreis, acopladas a mangueiras estéreis anexadas ao sistema de distribuição de gases. Tampas de borracha de butila e rosca plástica foram utilizadas para selar os reatores. Os sistemas foram colocados sob agitação de $150 \mathrm{rpm}$ (Domingues, 2001) e temperatura controlada a $30 \pm 2^{\circ} \mathrm{C}$. Amostras periódicas foram retiradas com seringa estéril, sob assepsia, para o acompanhamento da produção dos gases metano e óxido nitroso, análises de nitrato, nitrito e amônia, e exames microscópicos. Os ensaios foram realizados em batelada, em triplicatas de reatores. 
Tabela 3 - Composição do meio Zinder

\begin{tabular}{lc}
\hline \multicolumn{1}{c}{ Componentes } & $\begin{array}{c}\text { Quantidades - q.s.p. } \\
1000 \mathrm{~mL} \text { de água } \\
\text { ultrapurificada }\end{array}$ \\
\hline $\mathrm{NH}_{4} \mathrm{Cl}$ & $0,5 \mathrm{~g}$ \\
$\mathrm{KH}_{2} \mathrm{PO}_{4}$ & $0,4 \mathrm{~g}$ \\
$\mathrm{MgCl}_{2} \cdot 6 \mathrm{H}_{2} \mathrm{O}$ & $0,10 \mathrm{~g}$ \\
$\mathrm{CaCl}_{2} \cdot 2 \mathrm{H}_{2} \mathrm{O}$ & $0,05 \mathrm{~g}$ \\
$\mathrm{Na}_{2} \mathrm{HPO}_{4}$ & $1,2 \mathrm{~g}$ \\
$*$ Solução traço de metais & $10,0 \mathrm{~mL}$ \\
$*$ Solução de vitaminas & $10,0 \mathrm{~mL}$ \\
*Solução sulfeto de sódio $5 \%(\mathrm{p} / \mathrm{v})$ & $10,0 \mathrm{~mL}$ \\
*Solução bicarbonato de sódio $(10 \% \mathrm{p} / \mathrm{v})$ & $10,0 \mathrm{~mL}$ \\
*Resazurina $0,1 \%$ & $1,0 \mathrm{~mL}$ \\
\hline Fonte: Zinder et al. $(1984)$.
\end{tabular}

Fonte: Zinder et al. (1984).

* Soluções estoques.

Tabela 4 - Composição da solução traço de metais do meio Zinder

\begin{tabular}{lc}
\hline \multicolumn{1}{c}{ Componentes } & $\begin{array}{c}\text { Quantidades - q.s.p. 1000mL de } \\
\text { água ultrapurificada }\end{array}$ \\
\hline Triplex III & $4,5 \mathrm{~g}$ \\
FeSO$_{4} \cdot 7 \mathrm{H}_{2} \mathrm{O}$ & $0,556 \mathrm{~g}$ \\
$\mathrm{MnSO}_{4} \cdot \mathrm{H}_{2} \mathrm{O}$ & $0,086 \mathrm{~g}$ \\
$\mathrm{CoCl}_{2} \cdot 6 \mathrm{H}_{2} \mathrm{O}$ & $0,17 \mathrm{~g}$ \\
$\mathrm{ZnSO}_{4} \cdot 7 \mathrm{H}_{2} \mathrm{O}$ & $0,21 \mathrm{~g}$ \\
$\mathrm{H}_{3} \mathrm{BO}_{3}$ & 0,19 \\
$\mathrm{NiCl}_{2}$ & $0,02 \mathrm{~g}$ \\
$\mathrm{Na}_{2} \mathrm{MoO}_{4}$ & $0,01 \mathrm{~g}$ \\
\hline
\end{tabular}

Fonte: Zinder et al. (1984).

Tabela 5 - Composição da solução de vitaminas do meio Zinder Componentes Quantidades - q.s.p. $1000 \mathrm{~mL}$ de água ultrapurificada

\begin{tabular}{lc}
\hline Biotina & $0,002 \mathrm{~g}$ \\
Ácido fólico & $0,002 \mathrm{~g}$ \\
Tiamina $\mathrm{HCl}$ & $0,005 \mathrm{~g}$ \\
Riboflavina & $0,005 \mathrm{~g}$ \\
Ácido nicotínico & $0,005 \mathrm{~g}$ \\
Pantotenato de cálcio & $0,005 \mathrm{~g}$ \\
Priridoxina HCl & $0,010 \mathrm{~g}$ \\
Vitamina B12 & $0,0001 \mathrm{~g}$ \\
Ácido lipóico & $0,005 \mathrm{~g}$ \\
\hline
\end{tabular}

Fonte: Touzel e Albagnac. (1983). 
Tabela 6 - Composição do meio Dolfing

\begin{tabular}{|c|c|}
\hline Componentes & $\begin{array}{l}\text { Quantidades - q.s.p. 1000mL de } \\
\text { água ultrapurificada }\end{array}$ \\
\hline $\mathrm{KH}_{2} \mathrm{PO}_{4}$ & $0,33 \mathrm{~g}$ \\
\hline $\mathrm{Na}_{2} \mathrm{HPO}_{4}$ & $1,2 \mathrm{~g}$ \\
\hline $\mathrm{NH}_{4} \mathrm{Cl}$ & $0,11 \mathrm{~g}$ \\
\hline $\mathrm{MgSO}_{4} .7 \mathrm{H}_{2} \mathrm{O}$ & $0,10 \mathrm{~g}$ \\
\hline *Solução de $\mathrm{CaCl}_{2} .2 \mathrm{H}_{2} \mathrm{O}(4,4 \mathrm{~g} / \mathrm{L})$ & $10,0 \mathrm{~mL}$ \\
\hline *Solução traço de metais & $1 \mathrm{~mL}$ \\
\hline *Solução de sulfeto de sódio $5 \%(\mathrm{p} / \mathrm{v})$ & $10 \mathrm{~mL}$ \\
\hline
\end{tabular}

Fonte: Dolfing et al. (1990).

* Soluções estoques

Tabela 7 - Composição da solução traço de metais do meio Dolfing

\begin{tabular}{lc}
\hline & $\begin{array}{c}\text { Quantidades - q.s.p. 1000mL de água } \\
\text { ultrapurificada }\end{array}$ \\
\hline $\mathrm{FeSO}_{4} \cdot 7 \mathrm{H}_{2} \mathrm{O}$ & $1 \mathrm{mg}$ \\
$\mathrm{MnSO}_{4} \cdot \mathrm{H}_{2} \mathrm{O}$ & $1 \mathrm{mg}$ \\
$\left(\mathrm{NH}_{4}\right)_{6} \mathrm{Mo}_{7} \mathrm{O}_{24} \cdot 4 \mathrm{H}_{2} \mathrm{O}$ & $0,25 \mathrm{mg}$ \\
$\mathrm{Na}_{2} \mathrm{~B}_{4} \mathrm{O}_{7} \cdot 10 \mathrm{H}_{2} \mathrm{O}$ & $0,25 \mathrm{mg}$ \\
$\mathrm{Co}\left(\mathrm{NO}_{3}\right)_{2} \cdot 6 \mathrm{H}_{2} \mathrm{O}$ & $0,25 \mathrm{mg}$ \\
$\mathrm{CuCl}_{2} \cdot 2 \mathrm{H}_{2} \mathrm{O}$ & $0,25 \mathrm{mg}$ \\
$\mathrm{ZnCl}_{2}$ & $0,25 \mathrm{mg}$ \\
$\mathrm{NH}_{4} \mathrm{VO}_{3}$ & $0,1 \mathrm{mg}$ \\
\hline
\end{tabular}

Fonte: Zeyer e Kearney (1982).

Tabela 8-Composição dos reatores em batelada enriquecidos com meio Zinder

\begin{tabular}{lc}
\multicolumn{1}{c}{ Composição } & $\begin{array}{c}\text { Quantidade } \\
(\mathrm{mL})\end{array}$ \\
\hline Meio de cultura Zinder & 860 \\
Bicarbonato de sódio $(10 \%)$ & 10 \\
Solução de vitaminas & 10 \\
Acetato de sódio $(2 \mathrm{M})$ & 10 \\
Etanol (1M) & 10 \\
Nitrato de sódio $(1 \mathrm{M})$ & 10 \\
Sulfeto de sódio $(5 \%)$ & 10 \\
Inóculo & 80 \\
Volume total & 2000 \\
Headspace $\left(\mathrm{N}_{2} / \mathrm{CO}_{2}\right)(70 / 30 \%)$ & 1000 \\
\hline
\end{tabular}


Tabela 9 - Composição dos reatores batelada enriquecidos com meio Dolfing

Composição $\quad$ Quantidade

$(\mathrm{mL})$

\begin{tabular}{lc}
\hline Meio de cultura Dolfing & 870 \\
Cloreto de cálcio & 10 \\
Acetato de sódio $(2 \mathrm{M})$ & 10 \\
Etanol $(1 \mathrm{Mm})$ & 10 \\
Nitrato de sódio $(1 \mathrm{M})$ & 10 \\
Sulfeto de sódio $(5 \%)$ & 10 \\
Inóculo & 80 \\
Volume total & 2000 \\
Headspace $\left(\mathrm{N}_{2}\right)(100 \%)$ & 1000 \\
\hline
\end{tabular}

As soluções foram preparadas de acordo com as técnicas para a manipulação de anaeróbios estritos descritas detalhadamente por Vazoller (1995). O quadro 4 apresenta resumo das condições nas quais as soluções utilizadas neste trabalho foram preparadas.

Quadro 4 - Condições de preparo das soluções estoques utilizadas no enriquecimento

\begin{tabular}{|c|c|c|c|}
\hline Solução & Esterilização & Condições & Manutenção \\
\hline Meio Zinder & $\begin{array}{c}\text { Autoclavação } \\
\left(20 \mathrm{~min}, 121^{\circ} \mathrm{C}, 1\right. \\
\mathrm{atm})\end{array}$ & $\begin{array}{c}\text { Assepsia } \\
\text { Fluxo de } \mathrm{N}_{2} / \mathrm{CO}_{2} \\
(70 / 30 \%) \\
\end{array}$ & $\begin{array}{c}\text { Escuro até o } \\
\text { momento da sua } \\
\text { utilização } \\
\end{array}$ \\
\hline Meio Dolfing & $\begin{array}{c}\text { Autoclavação } \\
\left(20 \mathrm{~min}, 121^{\circ} \mathrm{C}, 1\right. \\
\mathrm{atm})\end{array}$ & $\begin{array}{c}\text { Assepsia } \\
\text { Fluxo de } \mathrm{N}_{2}(100 \%)\end{array}$ & $\begin{array}{c}\text { Escuro até o } \\
\text { momento da sua } \\
\text { utilização }\end{array}$ \\
\hline $\begin{array}{l}\text { Traço de } \\
\text { metais }\end{array}$ & $\begin{array}{c}\text { Autoclavação } \\
\left(20 \mathrm{~min}, 121^{\circ} \mathrm{C}, 1\right. \\
\mathrm{atm})\end{array}$ & $\begin{array}{c}\text { Assepsia } \\
\text { Fluxo de } \mathrm{N}_{2}(100 \%)\end{array}$ & Escuro/geladeira \\
\hline Vitaminas & $\begin{array}{c}\text { Esterilização em } \\
\text { membrana } 0,22 \mu \mathrm{m}\end{array}$ & $\begin{array}{c}\text { Assepsia } \\
\text { Fluxo de } \mathrm{N}_{2}(100 \%)\end{array}$ & Escuro/geladeira \\
\hline $\begin{array}{c}\text { Bicarbonato } \\
\text { de sódio } \\
(10 \%)\end{array}$ & $\begin{array}{l}\text { Esterilização em } \\
\text { membrana } 0,22 \mu \mathrm{m}\end{array}$ & $\begin{array}{c}\text { Assepsia } \\
\text { Fluxo de } \mathrm{N}_{2}(100 \%)\end{array}$ & $\begin{array}{l}\text { Temperatura } \\
\text { ambiente }\end{array}$ \\
\hline $\begin{array}{l}\text { Sulfeto de } \\
\text { sódio } \\
(5 \%)\end{array}$ & $\begin{array}{l}\text { Esterilização em } \\
\text { membrana } 0,22 \mu \mathrm{m}\end{array}$ & $\begin{array}{c}\text { Assepsia } \\
\text { Fluxo de } \mathrm{N}_{2}(100 \%)\end{array}$ & $\begin{array}{c}\text { Escuro/temperatura } \\
\text { ambiente }\end{array}$ \\
\hline $\begin{array}{c}\text { Solução de } \\
\mathrm{CaCl}_{2} \cdot 2 \mathrm{H}_{2} \mathrm{O} \\
(4,4 \mathrm{~g} / \mathrm{L})\end{array}$ & $\begin{array}{l}\text { Esterilização em } \\
\text { membrana } 0,22 \mu \mathrm{m}\end{array}$ & $\begin{array}{c}\text { Assepsia } \\
\text { Fluxo de } \mathrm{N}_{2}(100 \%)\end{array}$ & $\begin{array}{l}\text { Temperatura } \\
\text { ambiente }\end{array}$ \\
\hline $\begin{array}{c}\text { Solução de } \\
\mathrm{NaNO}_{3}(1 \mathrm{M})\end{array}$ & $\begin{array}{c}\text { Autoclavação } \\
\left(20 \mathrm{~min}, 121^{\circ} \mathrm{C}\right)\end{array}$ & $\begin{array}{c}\text { Assepsia } \\
\text { Fluxo de } \mathrm{N}_{2}(100 \%)\end{array}$ & $\begin{array}{l}\text { Temperatura } \\
\text { ambiente }\end{array}$ \\
\hline $\begin{array}{l}\text { Solução de } \\
\text { Acetato de } \\
\text { sódio }(2 \mathrm{M})\end{array}$ & $\begin{array}{c}\text { Autoclavação } \\
\left(20 \text { min, } 121^{\circ} \mathrm{C}\right)\end{array}$ & $\begin{array}{c}\text { Assepsia } \\
\text { Fluxo de } \mathrm{N}_{2}(100 \%)\end{array}$ & $\begin{array}{l}\text { Temperatura } \\
\text { ambiente }\end{array}$ \\
\hline Etanol (1M) & $\begin{array}{c}\text { Autoclavação } \\
\left(20 \text { min, } 121^{\circ} \mathrm{C}\right.\end{array}$ & $\begin{array}{c}\text { Assepsia } \\
\text { Fluxo de } \mathrm{N}_{2}(100 \%)\end{array}$ & $\begin{array}{l}\text { Temperatura } \\
\text { ambiente }\end{array}$ \\
\hline
\end{tabular}




\subsection{Purificação do inóculo}

O ensaio de purificação do inóculo foi realizado pelo método das diluições seriais (Figura 4). As diluições foram realizadas em frascos estéreis de $100 \mathrm{~mL}$ selados com tampas de teflon. O meio de cultivo (meio Dolfing, $50 \mathrm{~mL}$ ) foi suplementado com nitrato de sódio $\left(140 \mathrm{mg} / \mathrm{L}-\mathrm{N}^{-N_{0}}{ }_{3}^{-}\right)$, solução contendo etanol $(460 \mathrm{mg} / \mathrm{L})$ e o hidrocarboneto específico (5mg/L). O headsapce foi mantido em 50\% (v/v). A maior diluição que apresentou crescimento foi, mais uma vez, serialmente diluída. Uma alíquota da maior diluição, desta nova série, foi utilizada como inóculo para o isolamento em placa de Petri. As purificações foram realizadas para benzeno, tolueno, etilbenzeno, $o$-xileno, $m$-xileno, e $p$-xileno, separadamente.

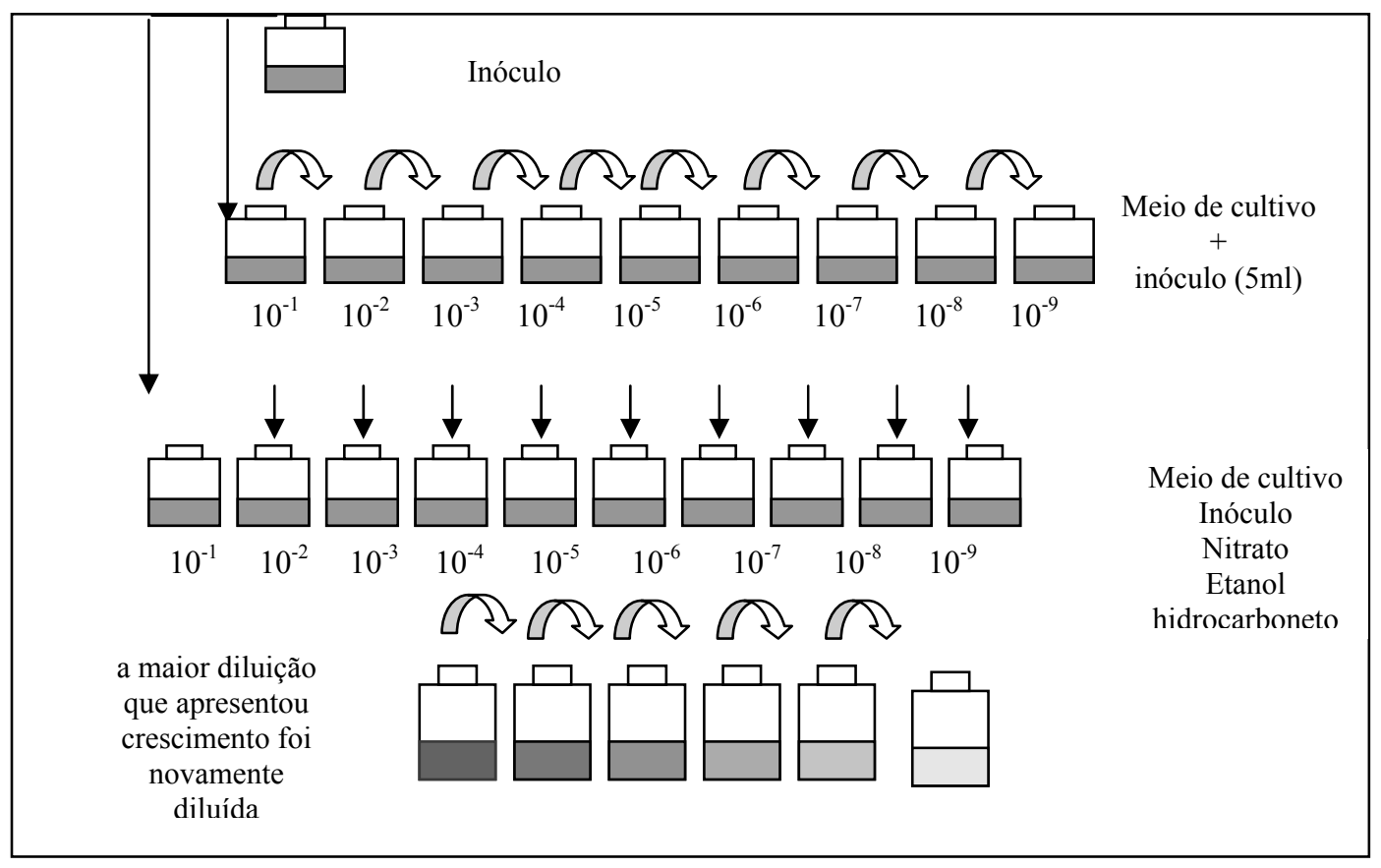

Figura 4 - Esquema da metodologia da diluição seriada.

\subsection{Purificação em placa de Petri}

A purificação foi realizada utilizando-se a metodologia de esgotamento por meio de estrias superficiais em placas de Petri. O meio de cultivo recebeu ágar 1,4\% (p/v) e foi autoclavado. Após autoclavação, o meio foi deixado em banho-maria até que atingisse temperatura próxima à temperatura ambiente. Nestas condições, o meio foi 
suplementado com etanol $(460 \mathrm{mg} / \mathrm{L})$, nitrato de sódio $(350 \mathrm{mg} / \mathrm{L})$ e o hidrocarboneto $(10 \mathrm{mg} / \mathrm{L})$. O meio foi distribuído, sob assepsia, em placas de Petri estéreis e, após solidificação, o inóculo, anteriormente purificado, foi semeado com alça de platina, na superfície do meio solidificado, utilizando-se a metodologia do esgotamento por meio de estrias superficiais em placas de Petri. As placas foram incubadas em jarra de anaerobiose $\left(\mathrm{BBL}^{\mathrm{TM}}\right.$ GasPack $^{\mathrm{TM}}$ Anaerobic Systems), submetidas a atmosfera de $\mathrm{N}_{2}$ (100\%), por 5 minutos. A jarra foi incubada em estufa a $30 \pm 2^{\circ} \mathrm{C}$, por 48 horas. $\mathrm{O}$ isolamento foi realizado para benzeno, tolueno, etilbenzeno, $o$-xileno, $m$-xileno e $p$ xileno, separadamente, entretanto, as placas que produziram os melhores resultados (menor diversidade morfológica) foram observadas somente para os isolamentos realizados em benzeno e etilbenzeno (diluição $10^{-5}$ ).

\subsection{Aumento da massa celular}

Objetivando-se aumentar a massa celular obtida das culturas isoladas em benzeno e etilbenzeno, uma única colônia, de cada isolamento, foi inicialmente transferida para meio líquido $(10 \mathrm{ml})$ com composição e concentrações idênticas àquelas utilizadas para a purificação em placa de Petri. Para favorecer a solubilidade do hidrocarboneto foi utilizada no meio de cultivo, solução de etanol (460 mg/L) acrescida do hidrocarboneto $(10 \mathrm{mg} / \mathrm{L})$. O aumento da massa celular foi realizado centrifugando-se por 5 minutos a $6000 \mathrm{rpm}$ e $10^{\circ} \mathrm{C}$, a cultura crescida em meio líquido (48 horas), e transferindo-se o pellet celular para volumes cada vez maiores de meio de cultivo fresco, até que se atingisse volume final de solução de $1000 \mathrm{ml}$.

\subsection{Manutenção das culturas}

O repique da cultura foi realizado uma vez por mês. A cultura em suspensão foi transferida para tubos estéreis de $50 \mathrm{~mL}$, os quais foram submetidos a centrifugação durante 5 minutos a $6000 \mathrm{rpm}$ e $10^{\circ} \mathrm{C}$. O pellet resultante (aproximadamente $5 \mathrm{ml}$ ) foi transferido para meio de cultivo fresco, contendo nitrato e solução etanólica acrescida do hidrocarboneto específico. 


\subsection{Caracterização nutricional das culturas}

Os ensaios de caracterização nutricional foram realizados em triplicatas, em frascos de $100 \mathrm{~mL}$, previamente esterilizados. Dois frascos forneceram amostras para verificação de crescimento e o terceiro, para realização de exames microscópicos. Todas as soluções utilizadas foram preparadas sob condições assépticas. Quatorze substâncias (Tabela 10) foram avaliadas como possíveis substratos para o crescimento celular em condições desnitrificante, sulfetogênicas e fermentativas. As soluções estoques dos substratos foram preparadas na concentração de $500 \mathrm{mM}$. O meio basal utilizado foi acrescido dos substratos orgânicos e nitrato ou sulfato (desnitrificação ou redução do sulfato), ou sem aceptor final de elétrons (fermentação), conforme esquematizado na Tabela 10.

A biomassa utilizada como inóculo foi previamente crescida durante 48 horas, em etanol $(10 \mathrm{mM})$, nitrato de sódio $(10 \mathrm{mM})$ e do hidrocarboneto $(10 \mathrm{mg} / \mathrm{L})$, transferida para frascos apropriados e submetida a centrifugação $\left(10^{\circ} \mathrm{C}\right)$ a $6000 \mathrm{rpm}$, durante 5 minutos. O sobrenadante foi descartado e o pellet ressuspenso em meio basal estéril. Em todos os ensaios de caracterização nutricional foi utilizado $1 \%(\mathrm{v} / \mathrm{v})$ do inóculo. Os ensaios foram realizados com concentrações do substrato de $1 \mathrm{mM}$ e $10 \mathrm{mM}$, exceto para a condição sulfetogênica, em que a concentração dos substratos utilizada foi de $1 \mathrm{mM}$. Para os compostos de BTEX, utilizou-se a concentração de $30 \mathrm{mg} / \mathrm{L}$ de cada composto e $10 \mathrm{mM}$ de etanol e, nos ensaios desnitrificantes, nitrato foi adicionado, em média 30\%, além dos cálculos estequiométricos, para garantir o crescimento.

Os frascos foram incubados a $30^{\circ} \pm 2^{\circ} \mathrm{C}$, e o crescimento celular avaliado após 30 horas de crescimento. Três mililitros da cultura em suspensão foram centrifugados, homogeneizando-se o pellet em $3 \mathrm{~mL}$ de água utrapurificada. Posteriormente, foi realizada a leitura da absorbância $(600 \mathrm{~nm})$, em espectrofotômetro com duplicata de amostras. 
Tabela 10. Composição dos frascos nos ensaios de caracterização nutricional.

\begin{tabular}{|c|c|c|c|}
\hline $\begin{array}{l}\text { Substrato } \\
\text { orgânico }\end{array}$ & $\begin{array}{c}\text { Sulfetogênese/ } \\
\text { substrato orgânico } \\
(1 \mathrm{mM})\end{array}$ & $\begin{array}{c}\text { Desnitrificação/ } \\
\text { substrato orgânico } \\
(10 \mathrm{mM}) \\
\end{array}$ & $\begin{array}{c}\text { Fermentação/ } \\
\text { substrato rgânico } \\
(10 \mathrm{mM}) \\
\end{array}$ \\
\hline $\begin{array}{l}\text { Acetato } \\
\text { de sódio }\end{array}$ & $\begin{array}{c}100 \mu \mathrm{L} \text { de solução estoque } \\
1,5 \mathrm{mg} \text { de } \mathrm{N}-\mathrm{NO}_{3}^{-}\end{array}$ & $\begin{array}{c}1 \mathrm{~mL} \text { de solução estoque } \\
15 \mathrm{mg} \text { de } \mathrm{N}-\mathrm{NO}_{3}^{-}\end{array}$ & $\begin{array}{c}100 \mu \mathrm{L} \\
\text { sol. estoque }\end{array}$ \\
\hline Glicose & $\begin{array}{c}100 \mu \mathrm{L} \text { de solução estoque } \\
4 \mathrm{mg} \text { de } \mathrm{N}-\mathrm{NO}_{3}^{-}\end{array}$ & $\begin{array}{l}1 \mathrm{~mL} \text { de solução estoque } \\
40 \mathrm{mg} \text { de } \mathrm{N}-\mathrm{NO}_{3}^{-}\end{array}$ & $\begin{array}{c}100 \mu \mathrm{L} \\
\text { sol. estoque }\end{array}$ \\
\hline $\begin{array}{l}\text { Lactato } \\
\text { de sódio }\end{array}$ & $\begin{array}{l}100 \mu \mathrm{L} \text { de solução estoque } \\
2 \mathrm{mg} \text { de N-NO}{ }^{-}\end{array}$ & 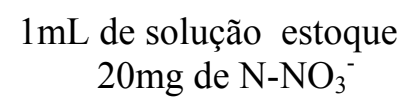 & $\begin{array}{c}100 \mu \mathrm{L} \\
\text { sol. estoque }\end{array}$ \\
\hline $\begin{array}{l}\text { Propionato } \\
\text { de sódio }\end{array}$ & $\begin{array}{c}100 \mu \mathrm{L} \text { de solução estoque } \\
2,5 \mathrm{mg} \text { de } \mathrm{N}-\mathrm{NO}_{3}{ }^{-}\end{array}$ & $\begin{array}{l}1 \mathrm{~mL} \text { de solução estoque } \\
25 \mathrm{mg} \text { de } \mathrm{N}-\mathrm{NO}_{3}{ }^{-}\end{array}$ & $\begin{array}{c}100 \mu \mathrm{L} \\
\text { sol. estoque }\end{array}$ \\
\hline $\begin{array}{l}\text { Butirato } \\
\text { de sódio }\end{array}$ & $\begin{array}{c}100 \mu \mathrm{L} \text { de solução estoque } \\
3,5 \mathrm{mg} \text { de } \mathrm{N}^{-\mathrm{NO}_{3}}{ }^{-}\end{array}$ & $\begin{array}{l}1 \mathrm{~mL} \text { de solução estoque } \\
35 \mathrm{mg} \text { de } \mathrm{N}-\mathrm{NO}_{3}{ }^{-}\end{array}$ & $\begin{array}{c}100 \mu \mathrm{L} \\
\text { sol. estoque }\end{array}$ \\
\hline $\begin{array}{l}\text { Piruvato de } \\
\text { sódio }\end{array}$ & $\begin{array}{l}100 \mu \mathrm{L} \text { de solução estoque } \\
2 \mathrm{mg} \text { de N-NO}{ }^{-}\end{array}$ & $\begin{array}{l}1 \mathrm{~mL} \text { de solução estoque } \\
20 \mathrm{mg} \text { de } \mathrm{N}-\mathrm{NO}_{3}^{-}\end{array}$ & $\begin{array}{l}100 \mu \mathrm{L} \\
\text { sol. estoque }\end{array}$ \\
\hline Etanol & $\begin{array}{c}100 \mu \mathrm{L} \text { de solução estoque } \\
2 \mathrm{mg} \text { de } \mathrm{N}-\mathrm{NO}_{3}^{-}\end{array}$ & $\begin{array}{l}1 \mathrm{~mL} \text { de solução estoque } \\
20 \mathrm{mg} \text { de } \mathrm{N}-\mathrm{NO}_{3}^{-}\end{array}$ & $\begin{array}{c}100 \mu \mathrm{L} \\
\text { sol. estoque }\end{array}$ \\
\hline Metanol & $\begin{array}{c}100 \mu \mathrm{L} \text { de solução estoque } \\
1 \mathrm{mg} \text { de } \mathrm{N}^{-\mathrm{NO}_{3}^{-}}\end{array}$ & 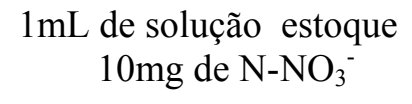 & $\begin{array}{c}100 \mu \mathrm{L} \\
\text { sol .estoque }\end{array}$ \\
\hline $\begin{array}{l}\text { Benzoato } \\
\text { de sódio }\end{array}$ & $\begin{array}{c}100 \mu \mathrm{L} \text { de solução estoque } \\
5 \mathrm{mg} \text { de } \mathrm{N}-\mathrm{NO}_{3}^{-}\end{array}$ & $\begin{array}{l}1 \mathrm{~mL} \text { de solução estoque } \\
50 \mathrm{mg} \text { de } \mathrm{N}-\mathrm{NO}_{3}^{-}\end{array}$ & $\begin{array}{c}100 \mu \mathrm{L} \\
\text { sol.estoque }\end{array}$ \\
\hline Fenol & $\begin{array}{c}100 \mu \mathrm{L} \text { de solução estoque } \\
5 \mathrm{mg} \text { de } \mathrm{N}-\mathrm{NO}_{3}^{-}\end{array}$ & $\begin{array}{c}1 \mathrm{~mL} \text { de solução estoque } \\
50 \mathrm{mg} \text { de } \mathrm{N}-\mathrm{NO}_{3}^{-}\end{array}$ & $\begin{array}{c}100 \mu \mathrm{L} \\
\text { sol. estoque }\end{array}$ \\
\hline Benzeno & $\begin{array}{l}1704 \mu \mathrm{L} \text { de benzeno } \\
5 \mathrm{mg} \text { de } \mathrm{N}-\mathrm{NO}_{3}^{-}\end{array}$ & $\begin{array}{l}50 \mu \mathrm{L} \text { de solução estoque } \\
25 \mathrm{mg} \text { de } \mathrm{N}-\mathrm{NO}_{3}^{-}\end{array}$ & $\begin{array}{c}50 \mu \mathrm{L} \\
\text { sol. estoque }\end{array}$ \\
\hline Tolueno & $\begin{array}{l}1704 \mu \mathrm{L} \text { de tolueno } \\
5 \mathrm{mg} \text { de } \mathrm{N}-\mathrm{NO}_{3}^{-}\end{array}$ & $\begin{array}{c}50 \mu \mathrm{L} \text { de solução estoque } \\
25 \mathrm{mg} \text { de } \mathrm{N}-\mathrm{NO}_{3}^{-}\end{array}$ & $\begin{array}{c}50 \mu \mathrm{L} \\
\text { sol. estoque }\end{array}$ \\
\hline Etilbenzeno & $\begin{array}{c}1704 \mu \mathrm{L} \text { de etilbenzeno } \\
5 \mathrm{mg} \text { de } \mathrm{N}_{-} \mathrm{NO}_{3}^{-}\end{array}$ & $\begin{array}{l}50 \mu \mathrm{L} \text { de solução estoque } \\
25 \mathrm{mg} \text { de } \mathrm{N}-\mathrm{NO}_{3}^{-}\end{array}$ & $\begin{array}{c}50 \mu \mathrm{L} \\
\text { sol. estoque }\end{array}$ \\
\hline p-Xileno & $\begin{array}{c}1704 \mu \mathrm{L} \text { de } \mathrm{p} \text {-xileno } \\
5 \mathrm{mg} \text { de } \mathrm{N}-\mathrm{NO}_{3}^{-}\end{array}$ & 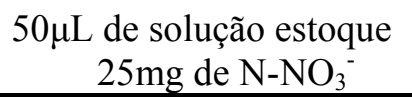 & $\begin{array}{c}50 \mu \mathrm{L} \\
\text { sol. estoque }\end{array}$ \\
\hline
\end{tabular}




\subsection{Ensaios em reatores batelada}

\subsubsection{Determinação do tempo de geração das culturas}

Os ensaios para obtenção da velocidade de crescimento e do tempo de geração das culturas isoladas foram realizados em reatores batelada com volume total de dois litros (Figura 5).

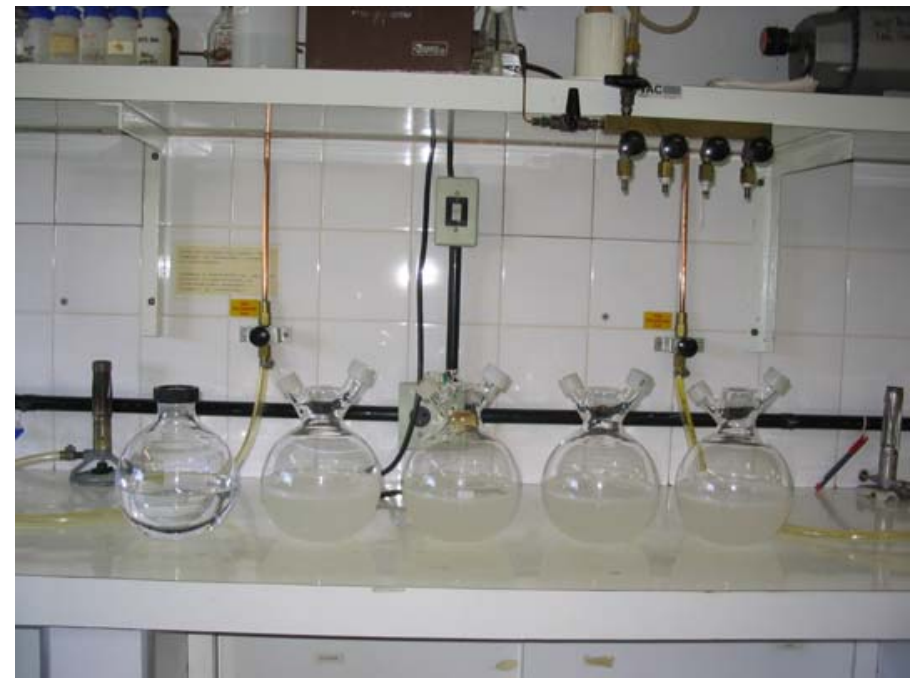

Figura 5 - Reatores utilizados nos ensaios de determinação do tempo de geração

Nesses ensaios foi utilizado meio de cultivo descrito por Dolfing et al. (1990), como descrito anteriormente. Os reatores foram preenchidos com meio de cultivo e suplementados conforme representado na Tabela 11. O headspace foi mantido em $50 \%$ (v/v) do volume total do reator e preenchido com atmosfera de $\mathrm{N}_{2}(100 \%)$. Os ensaios foram realizados em duplicata de reatores. As culturas em crescimento planctônico foram transferidas para frascos apropriados e submetida a centrifugação $\left(10^{\circ} \mathrm{C}\right)$ a 6000rpm, durante 3 minutos, visando lavar as células, retirar possíveis intermediários metabólicos e obter biomassa concentrada. 
Tabela 11. Composição dos reatores utilizados para avaliação do crescimento celular. Experimento em batelada

\begin{tabular}{|c|c|}
\hline Reator & Condição Nutricional \\
\hline Reator1 e Reator2 & $\begin{array}{c}\text { 3mL de inóculo (cultura isolada em benzeno) } \\
\text { Benzeno } 10 \mathrm{mg} / \mathrm{L} \\
\text { Etanol }(460 \mathrm{mg} / \mathrm{L}) \\
\text { Nitrato de sódio }(350 \mathrm{mg} \mathrm{NO} / \mathrm{L})\end{array}$ \\
\hline Reator 3 e Reator 4 & $\begin{array}{c}\text { 3mL de inóculo (cultura isolada em benzeno) } \\
\text { Etanol }(460 \mathrm{mg} / \mathrm{L}) \\
\text { Nitrato de sódio }(350 \mathrm{mg} \mathrm{NO} / \mathrm{L})\end{array}$ \\
\hline Reator 5 controle & $\begin{array}{c}\text { Sem inóculo } \\
\text { Benzeno } 10 \mathrm{mg} / \mathrm{L} \\
\text { Etanol }(460 \mathrm{mg} / \mathrm{L}) \\
\text { Nitrato de sódio }(350 \mathrm{mg} \mathrm{NO} / \mathrm{L})\end{array}$ \\
\hline Reator 6 e Reator 7 & $\begin{array}{c}\text { 3mL de inóculo (cultura isolada em etilbenzeno) } \\
\text { Etilbenzeno } 10 \mathrm{mg} / \mathrm{L} \\
\text { Etanol }(460 \mathrm{mg} / \mathrm{L}) \\
\text { Nitrato de sódio }(350 \mathrm{mg} \mathrm{NO} / \mathrm{L})\end{array}$ \\
\hline Heator & $\begin{array}{c}\text { 3mL de inóculo (cultura isolada em etilbenzeno) } \\
\text { Etanol }(460 \mathrm{mg} / \mathrm{L}) \\
\text { Nitrato de sódio }(350 \mathrm{mg} \mathrm{NO} / \mathrm{L})\end{array}$ \\
\hline Reator 10 controle & $\begin{array}{c}\text { Sem inóculo } \\
\text { Etilbenzeno } 10 \mathrm{mg} / \mathrm{L} \\
\text { Etanol }(460 \mathrm{mg} / \mathrm{L}) \\
\text { Nitrato de sódio }(350 \mathrm{mg} \mathrm{NO} / \mathrm{L})\end{array}$ \\
\hline
\end{tabular}

Os reatores foram vedados com tampas de teflon e mantidos em agitação (100rpm) e temperatura controlada em $30^{\circ} \pm 2^{\circ} \mathrm{C}$.

As amostras foram retiradas com seringas estéreis, sendo que o volume de amostra retirada não excedeu $10 \%$ (v/v) do volume total de reação.

O crescimento celular foi avaliado centrifugando-se $3 \mathrm{~mL}$ da amostra dos reatores e homogeneizando-se o pellet em $3 \mathrm{~mL}$ de água ultrapurificada (sistema milliQ). A leitura da absorbância $(600 \mathrm{~nm})$ foi realizada em espectrofotômetro DR $4000 \mathrm{U}$ ( $\mathrm{HACH})$.

Nestes ensaios, foi também analisado o consumo de nitrato $\left(\mathrm{N}^{-\mathrm{NO}_{3}}{ }^{-}\right)$, a variação da concentração dos hidrocarbonetos e de etanol. As metodologias empregadas para estas análises estão descritas posteriormente.

A determinação da velocidade específica na fase exponencial de crescimento $(\mu)$ foi feita graficamente, projetando-se os valores do logaritmo neperiano da absorbância versus tempo, onde identificou-se os pontos que possuíam a maior probabilidade de se alinharem numa mesma reta. Estes pontos correspondem à fase exponencial do 
crescimento em que a velocidade é máxima e constante (Varesche, 1997). Através do cálculo da regressão linear dos pares de pontos, determinou-se a equação da reta cujo coeficiente angular correspondeu ao valor de $\mu$. A partir da velocidade de crescimento da cultura calculou-se o tempo de geração da cultura (Tg) de acordo com a fórmula descrita a seguir.

$$
\operatorname{Tg}=\frac{\ln 2}{\mu}
$$

\subsection{Ensaios em reator anaeróbio horizontal de leito fixo (RAHLF)}

\subsubsection{Configuração do reator}

A Figura 6 mostra a fotografia dos reatores anaeróbios de leito fixo (RAHLF) utilizados no presente estudo. Os reatores foram confeccionados em vidro borossilicato, e possuíam as seguintes características: $100 \mathrm{~cm}$ de comprimento, $5,0 \mathrm{~cm}$ de diâmetro, relação extensão/diâmetro (L/D) de 20, volume total de 1995ml, e volume líquido de $800 \mathrm{ml}$. O reator consistiu de 5 pontos de amostragens intermediários distribuídos ao longo de seu comprimento ( $\mathrm{L} / \mathrm{D}=4,8,12$, 16, e 20). Partículas cúbicas de espumas de poliuretano $\left(5 \mathrm{~mm}\right.$ em tamanho e densidade aparente de $\left.23 \mathrm{~kg} / \mathrm{m}^{3}\right)$ foram usadas como suporte para imobilização da biomassa, resultando na porosidade de leito de $40 \%$. Os reatores também possuíam sistema coletor de gás. Ambos reatores foram operados com tempo de detenção hidráulica de 12 horas, com base no volume líquido, e vazão de $0,0185 \mathrm{~mL} / \mathrm{s}$

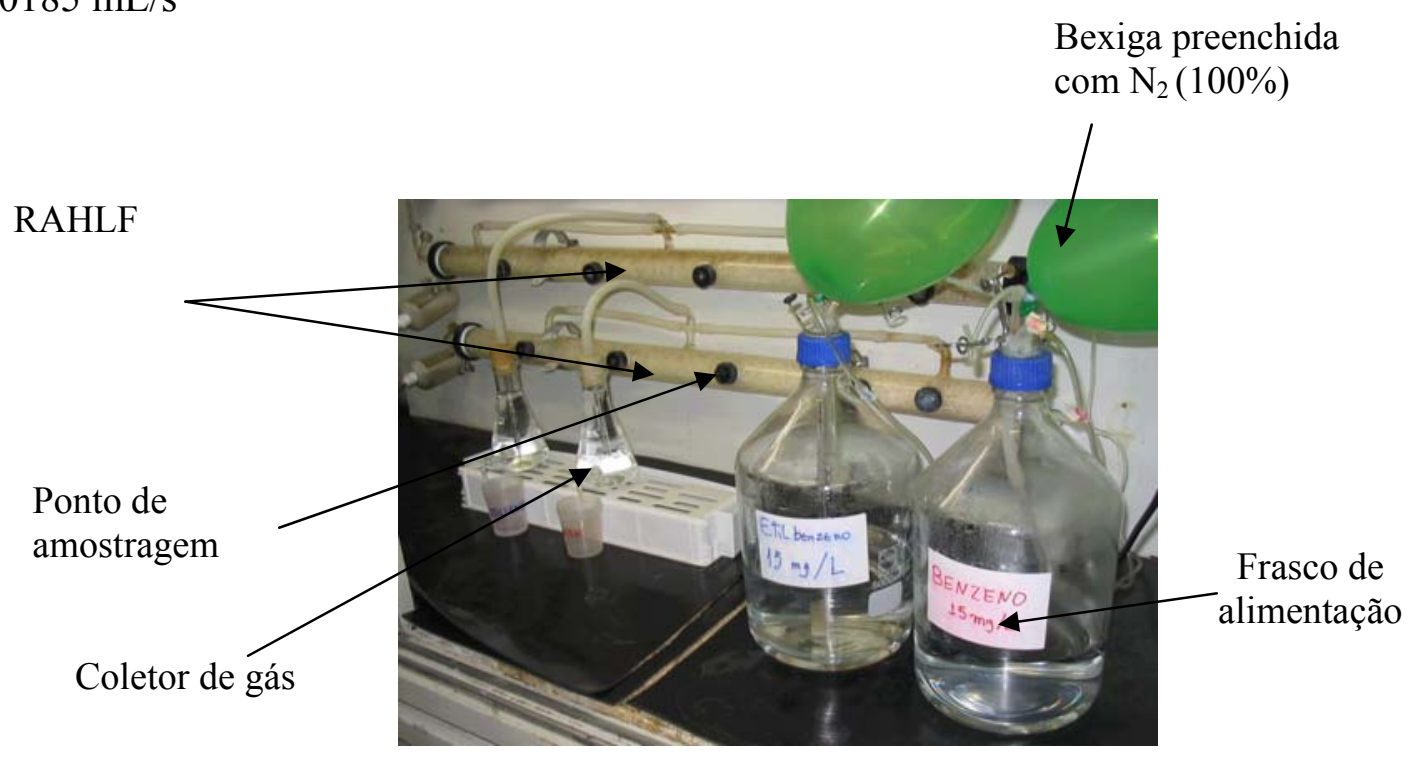

Figura 6 - Fotografia do RALHF instalado na câmara aclimatizada. 
Os RAHLFs foram instalados em câmara com temperatura controlada $\left(30^{\circ} \pm 1^{\circ} \mathrm{C}\right)$ e alimentados através de bomba peristáltica. Os reatores foram preenchidos com os cubos de poliuretano esterilizados, e alimentados com substrato contendo meio de cultura Dolfing, etanol $(460 \mathrm{mg} / \mathrm{L})$, nitrato (estequiometricamente calculado para cada condição) e os hidrocarbonetos, em diferentes concentrações. Foi mantida atmosfera de $\mathrm{N}_{2}(100 \%)$ nos reservatórios de alimentação, utilizando balão preenchido com esse gás.

\subsubsection{Imobilização das culturas nos reatores}

Anteriormente à imobilização de cada reator, as células isoladas foram repicadas em 4 litros de meio fresco, contendo o hidrocarboneto na mesma concentração a ser utilizada para alimentação do reator. Após 48 horas de crescimento, a $30^{\circ} \pm 2^{\circ} \mathrm{C}$, estas células foram utilizadas para imobilizar o reator, através da recirculação desta cultura, em circuito fechado, durante 2-3 dias, do seguindo modo: frasco de alimentação $\rightarrow$ reator $\rightarrow$ frasco de alimentação. Após este período, a recirculação era interrompida e o reator alimentado com substrato fresco.

\subsubsection{Alimentação dos reatores}

Os reatores foram alimentados com meio de cultivo Dolfing, suplementado de solução de nitrato de sódio e solução etanólica acrescida do hidrocarboneto. Soluções estoques de cada um dos componentes do meio Dolfing, assim como, as soluções de nitrato de sódio e traço de metais, foram esterilizadas e adicionadas a água ultrapurificada estéril. Para suprir um ciclo de alimentação de 48 horas, era preparado volume final 4 litros de substrato de alimentação.

\subsubsection{Solução etanólica com BTEX}

Foram preparadas soluções estoques de etanol e hidrocarboneto aromático (benzeno, tolueno, etilbenzeno, o-xileno, m-xileno, $p$-xileno) nas concentrações próximas a $10 \mathrm{~g} / \mathrm{L}$ de hidrocarboneto e $690 \mathrm{mg} / \mathrm{L}$ de etanol, ou $30 \mathrm{~g} / \mathrm{L}$ de hidrocarboneto e 
690mg/L de etanol, para as alimentações dos reatores nas concentrações próximas a $10 \mathrm{mg} / \mathrm{L}$ e $30 \mathrm{mg} / \mathrm{L}$ do hidrocarboneto, respectivamente. Estas soluções eram estocadas em frascos estéreis, fechados com tampas de butila revestida com teflon, lacradas com alumínio e armazenadas a $4^{\circ} \mathrm{C}$. Pouco antes de sua utilização, a solução era retirada da geladeira e deixada à temperatura ambiente, homogeneizada, e então, utilizada. O volume requerido para a alimentação do reator era retirado por meio de seringa estéril. Imediatamente após a adição desta solução, o frasco de alimentação era fechado e homogeneizado.

\subsubsection{Manutenção do reator}

Para minimizar o crescimento de microrganismos nas mangueiras e tampas, assim como em todo material utilizado na preparação do substrato de alimentação (pipetas, seringas, beckers, provetas) periodicamente procedia-se a esterilização em autoclave a $120^{\circ} \mathrm{C}$ e 1atm. Devido à troca freqüente das mangueiras de alimentação do reator, a calibração da bomba peristáltica, para a vazão desejada $(0,0185 \mathrm{~mL} / \mathrm{s})$, era realizada periodicamente.

\subsubsection{Estratégias utilizadas na operação dos reatores}

O reator RAHLF1 foi operado durante 189 dias consecutivos, e alimentado inicialmente com diferentes concentrações de benzeno. Posteriormente, o reator foi submetido á alimentação com tolueno, m-xileno, etilbenzeno e BTEX (solução contendo todos os hidrocarbonetos juntos).

O reator RAHLF2 foi operado por diferentes períodos, totalizando um período de operação de 277 dias. Inicialmente, o reator foi alimentado com diferentes concentrações de etilbenzeno. Posteriormente, foram avaliados benzeno, tolueno, $m$ xileno, o-xileno, $p$-xileno e BTEX, sendo que o meio suporte foi removido todas as vezes que um hidrocarboneto diferente era utilizado para alimentar o reator. 


\subsubsection{Análises realizadas no RAHLF}

A Tabela 12 apresenta, de forma resumida, os parâmetros avaliados no afluente e efluente dos reatores durante o período de operação e os métodos utilizados para avaliação destes parâmetros.

Tabela 12 - Parâmetros avaliados durante a operação dos RAHLFs e método analítico utilizado

Parâmetro

\begin{tabular}{ll}
\hline BTEX & Cromatografia gasosa \\
Ácidos voláteis $(\mathrm{mg} / \mathrm{L})$ & Cromatografia líquida \\
Alcalinidade $\left(\mathrm{mgCaCO}_{3} / \mathrm{L}\right)$ & Titulométrico \\
Ácidos Voláteis $(\mathrm{mg} \mathrm{HAc} / \mathrm{L})$ & Titulométrico \\
DQO bruta $(\mathrm{mg} / \mathrm{L})$ & Espectrofotométrico \\
DQO filtrada $(\mathrm{mg} / \mathrm{L})$ & Espectrofotométrico \\
$\mathrm{N}^{-N^{-}}{ }_{2}^{-}(\mathrm{mgN} / \mathrm{L})$ & Espectrofotométrico \\
$\mathrm{N}^{-N^{-}}{ }_{3}^{-}(\mathrm{mgN} / \mathrm{L})$ & Espectrofotométrico \\
$\mathrm{STV}(\mathrm{mg} / \mathrm{L})$ & Gravimétrico \\
$\mathrm{pH}$ & Potenciométrico \\
\hline
\end{tabular}

\subsection{Metodologias utilizadas nos ensaios}

\subsubsection{Exames microscópicos}

Os exames microscópicos, das amostras obtidas em todas as fases dos ensaios, foram realizados sob microscopia de contraste de fase, utilizando-se o Microscópio Olympus BX60-FLA, acoplado a câmera com captura de imagem e software Image-Pro Plus versão 4.5.0. Através desse equipamento foi possível captar as imagens e registrar as morfologias presentes nas amostras. Todas as observações microscópicas foram realizadas com as amostras obtidas a fresco.

Amostras do biofilme crescido nas espumas de poliuretano foram submetidas aos exames de microscopia eletrônica de varredura em microscópio de varredura digital Zeiss DSM-960. As amostras foram preparadas de acordo com Araújo et al. (2003). 


\subsubsection{Coloração de Gram}

Amostras obtidas dos isolamentos em benzeno e etilbenzeno foram submetidas à coloração de Gram realizada segundo a metodologia da Scientific Services of Cultures Collections da Alemanha (DSM, 1991) para diferenciação dos microrganismos.

\subsubsection{Análises Cromatográficas}

\subsubsection{1 Óxido nitroso e metano}

$\mathrm{O}$ método de inibição do acetileno $\left(\mathrm{C}_{2} \mathrm{H}_{2}\right)$ foi empregado para verificação da via metabólica utilizada pelos microrganismos, através da observação da produção de óxido nitroso $\left(\mathrm{N}_{2} \mathrm{O}\right)$ (Yoshinari e Knowles, 1976). Acetileno (10\% do volume do headspace do reator) foi injetado no reator, por meio de seringa estéril. As amostras de gás foram retiradas da fase gasosa utilizando-se seringas "gastight" $(1 \mathrm{~mL})$. As concentrações de $\mathrm{N}_{2} \mathrm{O}$ foram calculadas através da integração das áreas dos cromatogramas, utilizando-se curva padrão de acordo com a pureza do gás de 99\%. Foi utilizado cromatógrafo GowMac com coluna Porapak Q, com $2 \mathrm{~m}$ de comprimento e diâmetro de 1/4". O forno foi operado a temperatura de $25^{\circ} \mathrm{C}$. Como gás de arraste, foi utilizado o hidrogênio. A avaliação da produção de $\mathrm{N}_{2} \mathrm{O}$ foi realizada em duplicata.

As mesmas condições cromatográficas foram aplicadas para medir o teor de metano presente no biogás, determinado através da leitura correspondente em curva padrão.

\subsubsection{Análise de BTEX}

Esta análise foi realizada através da injeção do "headspace" do frasco. Para a quantificação, utilizou-se o método do padrão interno, pela introdução de quantidades iguais de solução de clorobenzeno em todas as amostras e nos padrões, a partir dos quais foi elaborada reta de calibração (diluiu-se diferente quantidade da substância a ser determinada em volumes iguais do substrato utilizado para alimentar os reatores, de onde foram retiradas as amostras para serem analisadas). A seguir está descrito, detalhadamente, a preparação da amostra e condições de análise. 


\section{Preparo das amostras:}

1) Os frascos $(10 \mathrm{~mL})$ foram previamente calibrados com pérolas de vidro, de forma que os volumes do "headspace" eram padronizados e constantes após a introdução das amostras. A seringa "gastight" $(1,0 \mathrm{~mL})$ com trava foi utilizada para injeção das amostras no cromatógrafo. Para calibração dos frascos, os mesmos foram numerados, pesados e sua massa seca, anotada. A seguir, cada frasco foi preenchido totalmente com água destilada, tomando-se o cuidado para que não ocorresse a formação de bolha de ar no seu interior. Posteriormente, os frascos foram fechados com tampa de butila revestida de teflon, pesados, e as massas dos frascos com a água foram anotadas. Com os valores da massa seca, e da massa com água, de cada frasco, e considerando a densidade da água $(1 \mathrm{~g} / \mathrm{mL})$, foi possível encontrar o volume de cada frasco, descontando-se a massa da tampa usada. A padronização dos volumes foi efetuada conhecendo-se as diferenças entre os volumes dos frascos maiores e menores. Conhecendo-se a densidade das pérolas de vidro $(2,47 \mathrm{~g} / \mathrm{mL})$, calculou-se as massas de pérolas necessária para compensar a diferença entre os frascos.

2) Utilizou-se volume de $2,0 \mathrm{~mL}$ de amostra e $2,0 \mathrm{~mL}$ de padrão interno (clorobenzeno $165 \mathrm{mg} / \mathrm{L}$ ), para a realização das análises.

3) Após colocar os volumes adequados de amostra e da solução de padrão interno nos frascos calibrados, os mesmos foram fechados com tampa de butila, revestida com teflon e lacrados com alumínio.

4) O frasco lacrado foi colocado em recipiente com água em ebulição, sobre uma placa de aquecimento e deixado por 10 minutos.

5) A seringa foi lavada com água e acetona e colocada em estufa, entre $60^{\circ} \mathrm{C}$ e $100^{\circ} \mathrm{C}$, até o momento da injeção.

6) $300 \mu \mathrm{L}$ do "headspace" do frasco de amostra foram coletados, procurando-se introduzir a agulha sempre na mesma altura (mais ou menos na metade do espaço do "headspace"). No momento da coleta da amostra; a seringa foi travada antes de ser retirada do frasco da amostra, e inserida no injetor do cromatógrafo. A trava da seringa foi aberta, e a amostra injetada. 


\section{Condições de análise:}

1) Cromatógrafo HP6890, com detector de ionização de chama, coluna HP - 1

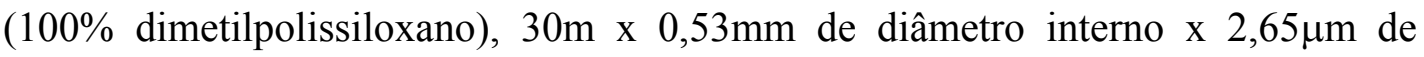
espessura de filme; gás de arraste: hidrogênio;

2) Temperatura do injetor: $250^{\circ} \mathrm{C}$, razão de split: 40 ; pressão: 2,8 psi (a $70^{\circ} \mathrm{C}$ ); "saver flow": $15 \mathrm{~mL} / \mathrm{min}$; lit offset: 1;

3) Temperatura do forno: $70^{\circ} \mathrm{C}\left( \pm 2^{\circ}\right)$ até $110^{\circ} \mathrm{C}\left( \pm 3^{\prime}\right)$;

4) Temperatura do detector: $300^{\circ} \mathrm{C}$, fluxo de hidrogênio: $30 \mathrm{~mL} / \mathrm{min}$.; fluxo de ar sintético: 300mL/min.; fluxo de gás auxiliar ("make-up"): $27 \mathrm{~mL} / \mathrm{min}$.; modo: col + "make-up": constante; litoffset: 1 .

*As análises foram realizadas em triplicatas nos ensaios em batelada e em duplicatas nos ensaios com RALHF.

\subsubsection{3 Ácidos voláteis por cromatografia}

A determinação de ácidos voláteis foi realizada em cromatógrafo gasoso HP 6890. A metodologia foi desenvolvida no Laboratório de Processos Biológicos da Escola de Engenharia de São Carlos - USP (Moraes et al., 2000), utilizando-se ácido crotônico como padrão interno em meio ácido (ácido sulfúrico) e extração com éter dietílico. A análise cromatográfica foi realizada nas seguintes condições:

- Temperatura do injetor: $250{ }^{\circ} \mathrm{C}$

- Temperatura do detector: $300{ }^{\circ} \mathrm{C}$

- Programação de temperatura da coluna:

- temperatura inicial: $100^{\circ} \mathrm{C}$

- taxa de aquecimento: $5{ }^{\circ} \mathrm{C} / \mathrm{min}$

- temperatura final: $180{ }^{\circ} \mathrm{C}(5 \mathrm{~min})$

- Razão de split: 20

- $\mathrm{H}_{2}$ para alimentar a chama: $30 \mathrm{~mL} / \mathrm{min}$

- Vazão do ar sintético: $300 \mathrm{~mL} / \mathrm{min}$

-Vazão do gás de make up $\left(\mathrm{N}_{2}\right): 33 \mathrm{~mL} / \mathrm{min}$ 
-Detector: ionização de chama

-Volume de amostra: $1,0 \mu \mathrm{L}$

\subsubsection{Análise de etanol}

A metodologia de determinação da concentração do etanol foi realizada por cromatografia líquida de acordo com Moraes et al. (2000). A análise foi realizada em croamtógrafo HP 6890, equipado com detector de ionização de chama-FID, com hidrogênio como gás de arraste, e coluna Innowax de $30 \mathrm{~m}$, di $=0,25 \mathrm{~mm}$; filme de 0,25um. As condições de análise foram as seguintes:

- Inlet:temperatura de $250^{\circ} \mathrm{C}$;

- Pressão de 10,0 psi;

- Relação de split - 20;

- Forno a $70^{\circ} \mathrm{C}$ graus $\left(3^{\prime}\right)-180^{\circ} \mathrm{C}\left(5^{\prime}\right)$, a $5^{\circ} \mathrm{C}$ por min;

- Temperatura do detector: $300^{\circ} \mathrm{C}$;

- Fluxo de Ar sintético de 300mL/min;

- Fluxo de N2 (gás auxiliar):35mL/min;

- Fluxo de H2: 30mL/min.

\subsubsection{Análises Físico-químicas}

\subsubsection{DQO, nitrato, nitrito, nitrogênio amoniacal e sólidos suspensos voláteis}

As análises de demanda química de oxigênio (DQO), nitrato $\left(\mathrm{N}^{-\mathrm{NO}_{3}}{ }^{-}\right)$, nitrito $\left(\mathrm{N}_{-} \mathrm{NO}_{2}{ }^{-}\right)$, nitrogênio amoniacal $\left(\mathrm{N}-\mathrm{NH}_{3}{ }^{+} \mathrm{N}_{-} \mathrm{NH}_{4}{ }^{+}\right)$(titulometria e espectrofotometria FIA) e sólidos suspensos voláteis (SSV) foram determinadas de acordo com as metodologias descritas no Standart Methods for Examination of Water and Wastewater (1998). Todas estas análises, exceto as referentes a SSV, foram realizadas em duplicatas. 


\subsubsection{Alcalinidade e ácidos voláteis por titulometria}

As análises de alcalinidade foram realizadas segundo o protocolo de Dillalo e Albertson (1961) modificado por Ripley et al. (1986). A amostra foi filtrada em membrana com tamanho de poros de $1,2 \mu \mathrm{m}$, previamente titulada com solução padronizada de ácido sulfúrico, até pH 5,75 (alcalinidade parcial devido ao bicarbonato) e $\mathrm{pH}$ 4,3 (alcalinidade intermediária devido aos ácidos voláteis). O volume gasto na titulação foi anotado e o cálculo para alcalinidade total foi realizado da seguinte forma:

$$
\mathrm{mg} / \mathrm{L} \text { de alcalinidade total, como } \mathrm{CaCO}_{3}=\frac{\mathrm{V}_{2} \text {. N. 50.000 }}{\mathrm{V}_{\mathrm{a}}}
$$

Sendo: $\mathrm{V}_{2}=$ volume de ácido gasto na titulação até $\mathrm{pH} 4,3$

$\mathrm{N}=$ normalidade do ácido empregado

$\mathrm{V}_{\mathrm{a}}=$ volume da amostra, $\mathrm{mL}$

Para a obtenção do valor da alcalinidade a bicarbonato, considerou-se o seguinte: (a) fator de correção de conversão da alcalinidade a ácidos voláteis e iguais a 0,833; (b) fator de conversão $(0,85)$, significando que somente $85 \%$ da alcalinidade a ácidos voláteis foram medidas pela titulação até pH 4,3.

$$
\mathrm{AB}=\mathrm{AT}-0,833 \times 0,85 . \mathrm{AV} \Rightarrow \quad \mathbf{A B}=\mathbf{A T}-\mathbf{0 , 7 1} \mathbf{A V}
$$

Sendo,

$\mathrm{AB}=$ Alcalinidade a bicarbonato

$\mathrm{AT}=$ Alcalinidade total

$\mathrm{AV}=$ Ácidos voláteis

Ácidos voláteis totais, como ácido acético, foram analisados segundo metodologia proposta por Dillalo e Albertson (1961). Após realizar análise de alcalinidade, o pH da amostra de 4,3 foi abaixado até 3,3 com ácido sulfúrico. A amostra foi fervida por 3 min para remover ácido carbônico como $\mathrm{CO}_{2}$ (interferente) e então titulada, com solução padronizada de hidróxido de sódio, de $\mathrm{pH} 4,0$ até 7,0. $\mathrm{O}$ volume gasto na titulação foi anotado e o cálculo realizado da seguinte forma:

$$
\mathrm{mg} / \mathrm{L} \mathrm{HAc}=\underline{\mathrm{V} . \mathrm{N} .60 .000}
$$


Sendo,

$\mathrm{HAc}=$ ácido acético

$\mathrm{V}=$ volume gasto de $\mathrm{NaOH}$ de $\mathrm{pH}$ 4,0 a 7,0

$\mathrm{N}=$ normalidade do $\mathrm{NaOH}$

$\mathrm{V}_{\mathrm{a}}=$ volume da amostra

\subsubsection{Potencial Redox}

A medida do potencial redox foi realizada com o aparelho Digimed modelo DM21 utilizando-se o eletrodo combinado de platina Pt4805 da Mettler-Toledo. O eletrodo foi introduzido no orifício da tampa do frasco contendo a cultura enriquecida, aguardando-se a estabilização dos valores registrados, para posterior anotação do potencial redox do meio reacional.

\subsubsection{Métodos moleculares}

Espumas imobilizadas com biomassa foram coletadas durante a realização dos perfis, para cada condição de alimentação. As amostras eram coletadas com pinças estéreis, transferidas para tubos apropriados e armazenadas em freezer até o momento da sua utilização.

\subsubsection{Extração de DNA}

A extração de DNA das amostras foi realizada através do método direto utilizando "glass beads", seguindo o procedimento descrito por Griffiths et al. (2000), como descrito a seguir:

- As amostras (cerca de 10 espumas) foram transferidas para tubos Falcon, maceradas com o auxílio de bastão de vidro, em $5 \mathrm{~mL}$ de PBS, e submetidas a centrifugação a $10^{\circ} \mathrm{C}$ por 5 min a 6000rpm. 
- O sobrenadante foi descartado e adicionou-se $0,5 \mathrm{~g}$ de glass beads, $1 \mathrm{ml}$ PBS $1 \mathrm{X}$, $1 \mathrm{ml}$ de clorofórmio e $1 \mathrm{ml}$ de fenol equilibrado $(\mathrm{pH}=8,0)$.

- Os tubos foram colocados em banho de gelo para inibir ação das enzimas e levados ao vortex por 60s.

- As amostras foram submetidas a centrifugação a $10^{\circ} \mathrm{C}$ por 5 min a $6000 \mathrm{rpm}$.

- Após centrifugação 3 fases foram observadas:

Fase 1 - PBS

Fase 2 - Clorofórmio

Fase 3 - Fenol

- A primeira fase foi retirada e transferida para tubo apropriado onde se adicionou aproximadamente $1 \mathrm{~mL}$ de fenol. O tubo foi submetido a agitação em vortex, somente para homogeneização e centrifugado a $10^{\circ} \mathrm{C}$ por $10 \mathrm{~min}$, e $14000 \mathrm{rpm}$.

- O sobrenadante foi transferido para novo tubo apropriado, e adicionou-se aproximadamente $1 \mathrm{~mL}$ de clorofórmio. $\mathrm{O}$ tubo foi submetido a agitação em vortex somente para homogeneização e centrifugado a $10^{\circ} \mathrm{C}$ por $10 \mathrm{~min}$, e 14000rpm. Este último procedimento foi realizado por mais duas vezes.

- O sobrenadante resultante foi armazenado em freezer $\left(-20^{\circ} \mathrm{C}\right)$ até o momento de sua utilização.

- Todo material utilizado durante a extração foi previamente esterilizado.

O produto da extração de DNA foi avaliado em gel de agarose $1,0 \%$, corado com brometo de etídeo $(0,5 \mathrm{mg} / \mathrm{L})$ por 5 minutos. O excesso do brometo de etídeo foi retirado através de lavagem do gel em água ultrapurificada, por 5 minutos. Os géis foram observados no fotodocumentador Eagle Eye TMIII (Stratagene), com luz ultravioleta, acoplado a microcomputador e Software Eagle Sight. Como marcador foi utilizado $\lambda$ Hind III fragment.

\subsubsection{Amplificação de DNA Ribossomal 16S (PCR)}

O DNA extraído foi amplificado através da reação de polimerização em cadeia (PCR). Utilizou-se o primer forward 968F (5'- AACGCGAAGAACCTTAC -3') com GC clamp (5'- CGC CCG GGG CGC GCC CCG GGC GGG GCG GGG GCA CGG GGGG -3') e o reverse 1392 R (5'- ACG GGC GGT GTG TAC -3') para o Domínio 
Bacteria (Nielsen et al., 1999), na avaliação da estrutura da comunidade microbiana por DGGE.

Duas culturas puras, Thauera chlrobenzóica (ATCC) e Azoarcus tolulyticus (ATCC) foram utilizadas como controle positivo do Domínio Bacteria.

As amplificações foram realizadas em termociclador "Gene Amp PCR System 2400" (Perkin-Elmer Cetus, Norwalk, Conn.). A qualidade do produto obtido no PCR foi confirmada em gel de agarose $1 \%$, sendo que as etapas para observação do gel foram as mesmas utilizadas para verificação do produto da extração de DNA. Como marcador foi utilizado $\phi \mathrm{K} 174$ HAE III. As condições de amplificação estão descritas na Tabela 13.

Tabela 13 - Condições de amplificação do PCR

\begin{tabular}{lccc}
\hline \multicolumn{1}{c}{ Etapa } & Temperatura $\left({ }^{\circ} \mathbf{C}\right)$ & Duração & Ciclos \\
\hline Pré-desnaturação & 94 & $5 \mathrm{~min}$ & 1 \\
Desnaturação & 94 & $45 \mathrm{seg}$ & 35 \\
Anelamento & 38 & $45 \mathrm{seg}$ & 35 \\
Extensão & 72 & $1 \mathrm{~min}$ & 1 \\
Extensão final & 72 & $5 \mathrm{~min}$ & 1 \\
\hline
\end{tabular}

\subsubsection{Eletroforese em gel de gradiente desnaturante (DGGE)}

A separação dos fragmentos de DNAr 16S, amplificados por PCR, foi utilizado o sistema DGGE-D Cодетм - Universal Mutation Detection System (Bio-Rad, Inc., Hercules, Califórnia), com gradiente de desnaturação do gel de 40\% a 60\%.

O protocolo descrito por Sakamoto (2001) foi utilizado e encontra-se apresentado a seguir:

1. Foram preparadas as soluções do gel nas concentrações de $0 \%, 40 \%$ e $60 \%$, de acordo com a Tabela 14, através da dissolução da uréia nos reagentes líquidos e completando o volume até $100 \mathrm{~mL}$ com água ultrapurificada. 
Tabela 14. Composição da solução do gel gradiente desnaturante.

\begin{tabular}{lccc}
\hline \multirow{2}{*}{ Reagentes } & \multicolumn{2}{c}{ Concentração do gel } \\
\cline { 2 - 4 } & $0 \%$ & $40 \%$ & $60 \%$ \\
\hline $40 \%$ de gel de acrilamida $(\mathrm{mL})$ & 20 & 20 & 20 \\
Solução de TAE 50 X $(\mathrm{mL})$ & 2 & 2 & 2 \\
Formamida $(\mathrm{mL})$ & - & 16 & 24 \\
Uréia $(\mathrm{g})$ & - & 16,8 & 25,2 \\
\hline
\end{tabular}

2. As placas de vidro foram cuidadosamente limpas e montadas em suporte apropriado;

3. Os três géis a serem introduzidos nas placas de vidro foram preparados, utilizando-se as soluções dos géis (Tabela 14), do seguinte modo:

- em tubos de centrífuga de $15 \mathrm{~mL}$, adicionou-se $14 \mathrm{~mL}$ da solução de $40 \%$, $100 \mu \mathrm{L}$ de $10 \%$ APS e $10 \mu \mathrm{L}$ de temed.

- em tubos de centrífuga de $15 \mathrm{~mL}$, adicionou-se $14 \mathrm{~mL}$ da solução de $60 \%$; $100 \mu 1$ de $10 \%$ APS; e $10 \mu 1$ de temed.

- em tubos de centrífuga de $15 \mathrm{~mL}$, adicionou-se $3 \mathrm{~mL}$ da solução de $0 \% ; 20 \mu 1$ de $10 \%$ APS; e $2 \mu 1$ de temed.

Obs: Os tubos de centrífuga contendo as soluções foram mantidos em gelo, durante a preparação dos géis. O temed foi adicionado por último, pois este reagente provocava a solidificação do gel. Por isso, depois de sua adição o gel foi usado imediatamente.

4. Cada gel (40\% e 60\%) foi transferido para uma das placas de vidro com auxílio de duas seringas presas ao aparelho injetor;

5. Após 10 minutos, o pente de formação dos poços foi introduzido nas placas. Em seguida, adicionou-se a solução do gel $0 \%$;

6. Aguardou-se 1 hora para os géis solidificarem;

7. A cuba de eletroforese foi preparada através da adição de $140 \mathrm{~mL}$ de TAE $50 \mathrm{X}$, completando o volume de 7 litros, com água ultrapurificada, o que resultou em solução TAE 1X;

8. Colocou-se a solução para aquecer a temperatura de $65^{\circ} \mathrm{C}$, sendo que a temperatura de "corrida" foi de $60{ }^{\circ} \mathrm{C}$; 
9. Quando a temperatura da cuba eletroforética atingiu $65^{\circ} \mathrm{C}$, foram colocados no seu interior as placas com os géis;

10. O "pente" foi retirado e os poços formados foram lavados com a solução tampão (TAE 1X), utilizando-se micropipeta;

11. Prepararam-se as amostras, misturando-se $20 \mu \mathrm{L}$ de amostra com $5 \mu \mathrm{L}$ de corante (6X loading dye);

12. Transferiu-se a mistura (amostra + corante) para os poços do gel;

13. A bomba de agitação foi ligada e eletrodos conectados à voltagem de $130 \mathrm{~V}$;

14. O tempo de "corrida" foi de $6 \mathrm{~h}$;

15. Os géis foram cuidadosamente retirados das placas e transferidos para uma cuba para que fossem corados em solução de brometo de etídeo $(0,5 \mathrm{mg} / \mathrm{L})$, por 15 minutos.

16. O excesso de brometo de etídeo foi retirado através da lavagem do gel em água ultrapurificada, por 10 minutos.

17. O gel foi transferido para fotodocumentador e a leitura realizada em luz violeta (Eagle Eye TMIII - Stratagene), acoplado a microcomputador e Software Eagle Sight.

\subsubsection{Clonagem e Sequenciamento}

As amostras obtidas do biofilme e do crescimento em suspensão (inóculo) foram amplificadas por PCR, utilizando "primers" 27f (5`-AGA GTT TGA TCC TGG CTC AG 3`) e 907r (5`-CCG TCA ATT CCT TTG AGT TT 3`), seguindo metodologia descrita por So e Young (1999). e os produtos obtidos foram misturados e clonados no plasmídio pCR 2.1 TOPO-TA easy vector system (Invitrogen), e transformado em E. Coli DHa5. O protocolo foi realizado de acordo com as instruções do fornecedor. Os clones foram seqüenciados em seqüenciador de DNA ABI 377 (Perkin Elmer) usando os primers M13 (forward e reverse, separadamente). As seqüências de nucleotídeos resultantes foram checadas usando DNASTAR (Lasergene Sequence Analysis Software), para correção dos nucleotídeos. Em seguida, as seqüências foram comparadas online com base eletrônica de dados NCBI BLAST. 


\subsection{Sequenciamento das bandas}

Amostras obtidas do biofilme referente ao reator RAHLF1 (final do período de alimentação com benzeno 26,5 mg/L e BTEX 26,5 mg/L) foram amplificadas por PCR utilizando-se primers descrito por Muyzer et al. (1993) 341f (5' - CCT ACG GGA GGA GGC AGC AG - 3') com GC clamp (5'- CGC CCG CCG CGC GCG GCG GGC GGG GCG GGG GCA CGG GGG GC-3') e 534r (5' - ATT ACC GCG GCT GCT GG - 3’). Os produtos de PCR foram utilizados para avaliar a diversidade da comunidade microbiana presente nas amostras, utilizando-se a metodologia do DGGE. As bandas mais expressivas foram recortadas do gel, eluídas em água destilada, re-amplificadas com primers descrito anteriormente (Muyzer et al., 1993), sem GC clamp, clonadas e submetidas ao sequenciamento, conforme descrito anteriormente. Como controle positivo foram utilizados três gêneros de Bactérias (Pseudomonas sp.; E. coli and Desulfococcus sp). Como controle negativo utilizou-se Methanosarcina sp. 


\section{RESULTADOS E DISCUSSÃO}

\subsection{Escolha do Inóculo}

Em geral, inóculos utilizados nos estudos relativos ao isolamento de microrganismos responsáveis pela degradação de hidrocarbonetos aromáticos, como os BTEX, são obtidos de locais já contaminados por estes compostos, uma vez que nestas áreas, a possibilidade de se isolar microrganismos adaptados a estes hidrocarbonetos é maior. No entanto, os microrganismos são altamente versáteis e estão amplamente distribuídos no ambiente. Assim, a investigação de inóculos alternativos deve ser considerada para que o estudo sobre a diversidade e versatilidade metabólica dos microrganismos capazes de realizar a remoção de BTEX, não se restrinja à aquisição de inóculo obtido de área contaminada por tais compostos. No presente estudo, utilizou-se como inóculo o lodo granular originado em reator anaeróbio de fluxo ascendente e manta de lodo (UASB) empregado no tratamento de água residuária de abatedouro de aves. Este inóculo já foi utilizado com sucesso nas diversas pesquisas desenvolvidas na área de Biotecnologia Ambiental, do Laboratório de Processos Anaeróbios, da Escola de Engenharia de São Carlos da Universidade de São Paulo, onde se comprovou a existência de ampla diversidade microbiana, estabelecida nos consórcios fisiológicos, fundamental para que a matéria orgânica fosse removida eficientemente (Nardi, 2002; Ribeiro, 2005; Cattony, 2005).

Fernandes (2005) estudando a influência de diferentes inóculos no processo de degradação anaeróbia de BTX, em reator anaeróbio horizontal de leito fixo, constatou que a origem do inóculo foi fundamental na degradação anaeróbia destes compostos, uma vez que, os inóculos avaliados apresentaram diferentes períodos de adaptação e porcentagens de degradação. Entre os inóculos, o que apresentou maior eficiência de remoção de BTX, ou seja, de $90 \%$, foi aquele contendo biomassa proveniente de reator UASB utilizado no tratamento de água residuária de abatedouro de aves, quando comparado com eficiências de $57 \%$ e $83 \%$, que foram obtidas para biomassa 
proveniente de RAHLF anteriormente submetido à alimentação com água contendo os hidrocarbonetos extraídos, e biomassa proveniente de reator UASB da estação de tratamento de esgoto sanitário da USP - São Carlos, respectivamente.

\subsection{Escolha dos meios de cultivos}

Os microrganismos são altamente afetados pelas condições físicas e químicas do ambiente onde se encontram. Muitos fatores ambientais podem afetar significativamente a habilidades dos microrganismos em realizar reações metabólicas e crescer. Assim, para que o crescimento celular seja satisfatório, fatores essenciais como presença de macronutrientes e micronutrientes, fatores de crescimento (vitaminas), assim como, controle do $\mathrm{pH}$, temperatura, e oxigênio devem ser observados nos estudos com microrganismos.

Visando obter condição de crescimento adequada para organismos desnitrificantes, no presente trabalho, foram estudados dois meios de cultura quimicamente definidos: (1) meio descrito por Zinder et al. (1984) e (2) meio proposto por Dolfing et al. (1990). As composições destes meios estão representadas na Tabelas 3 a 7 na seção Material e Métodos.

O meio Zinder vem sendo utilizado com sucesso no cultivo de microrganismos anaeróbios. Este meio de cultivo destaca-se por ser um meio equilibrado, apresentando fosfato, carbono e nitrogênio que são nutrientes essenciais para o crescimento celular. Entre os fatores presentes neste meio, que favorecem o crescimento de diversos grupos de microrganismos, encontram-se as vitaminas e a solução traço de metais.

A outra condição nutricional (meio Dolfing) foi escolhida para desenvolver este trabalho, por ter sido utilizada em estudo de cultivo e isolamento de uma linhagem de bactéria desnitrificante, capaz de degradar tolueno (Dolfing et al.,1990). Este meio apresenta composição semelhante ao meio de cultivo Zinder, diferenciando-se deste último, apenas, por não apresentar solução de vitaminas.

Comparando-se as composições dos dois meios testados, nota-se que ambos apresentam os compostos essenciais para cultivo de microrganismos. Embora soluções traços de metais diferenciadas tenham sido utilizadas nos meios de cultura, estas se apresentaram também semelhantes, em termos de composição. 
Sabe-se que vitaminas são, muitas vezes, requeridas para o crescimento dos microrganismos mais fastidiosos. No entanto, o acréscimo da solução de vitaminas nos ensaios com meio Zinder não foi determinante para favorecer ou selecionar os microrganismos presentes, uma vez que morfologias celulares muito semelhantes puderam ser observadas tanto no meio Zinder, como no meio Dolfing.

Para favorecer o crescimento dos microrganismos desnitrificantes, fonte de energia (doador de elétrons), que não seja rapidamente fermentável, deve ser adicionada ao meio, de forma que organismos fermentadores não sejam selecionados. Como fontes orgânicas adequadas para a desnitrificação incluem-se: etanol, acetato, succinato e benzoato (Madigan et al., 1997). No presente estudo, etanol e acetato foram utilizados como fontes orgânicas nos enriquecimentos dos meios de cultivos.

Os resultados dos enriquecimentos realizados em reatores em batelada demonstraram que, de forma semelhante, os dois meios de cultura favoreceram o crescimento celular. Os exames microscópicos das amostras dos reatores enriquecidos revelaram ampla diversidade morfológica do lodo, sendo que bacilos, cocobacilos e células semelhantes a Methanosaeta sp., foram as morfologias predominantes nos dois meios de cultura avaliados (Figuras 7 e 8).

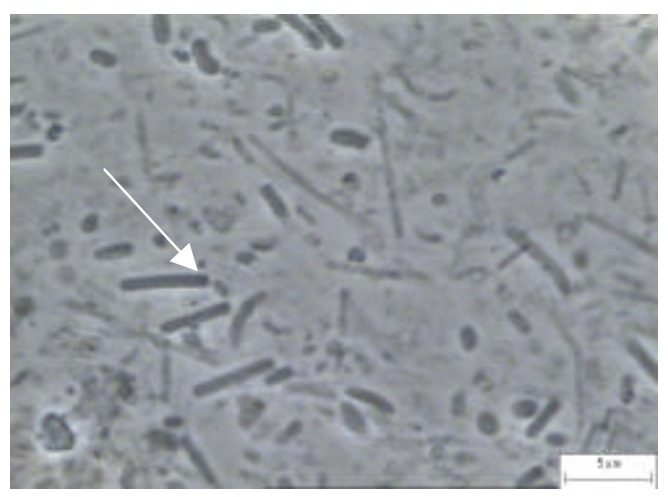

(a)

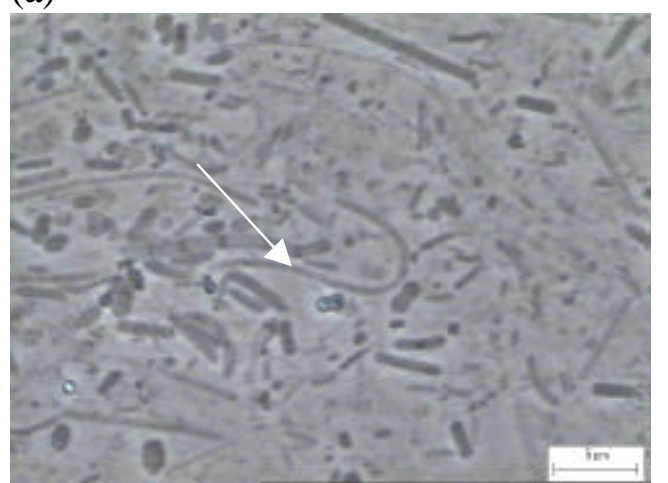

(c)

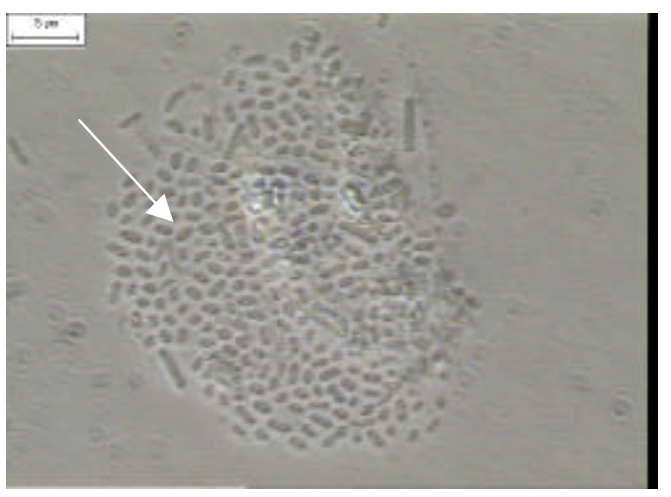

(b)

Figura 7 - Microscopia de contraste de fase das morfologias predominantes observadas em amostras dos reatores alimentados com meio Zinder: (a) bacilos, (b) cocobacilos, (c) morfologia semelhante a Methanosaeta sp. 1500X 


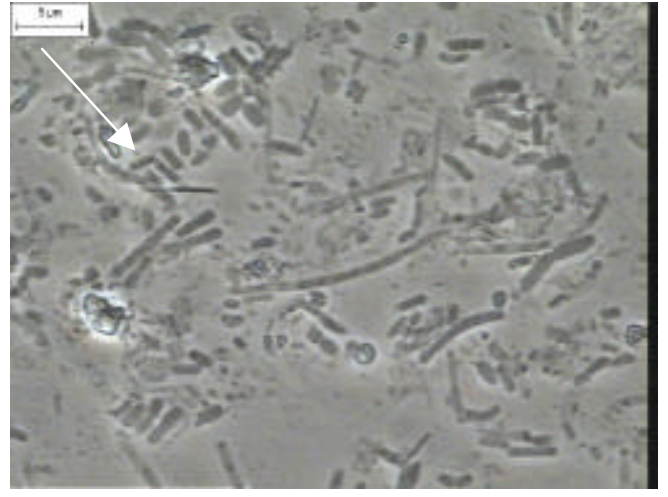

(a)

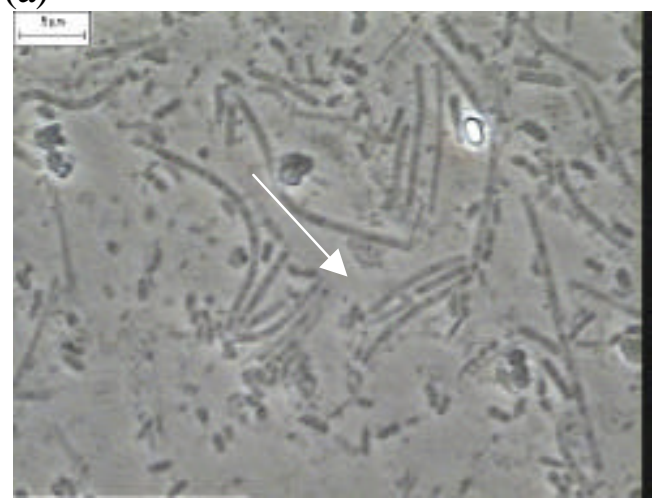

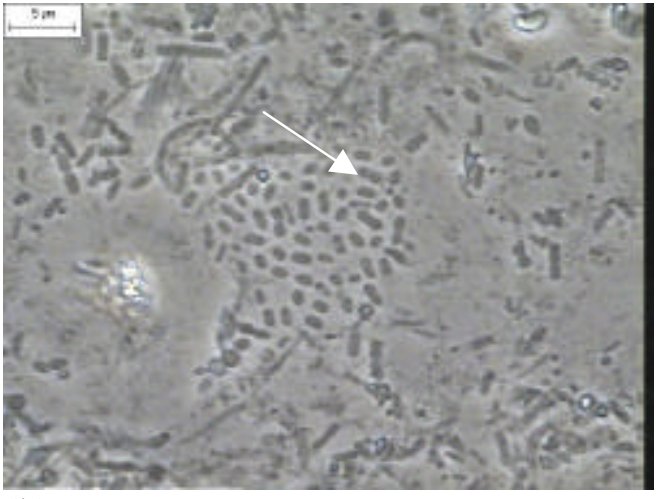

(b)

Figura 8 - Microscopia de contraste de fase das morfologias predominantes observadas em amostras dos reatores alimentados com meio Dolfing: (a) bacilos, (b) cocobacilos, (c) morfologia semelhante a Methanosaeta sp. 1500X

O consumo do nitrato $\left(\mathrm{N}^{-N_{3}}{ }^{-}\right)$foi avaliado em ensaios com triplicatas de reatores em batelada. Todavia, os primeiros resultados demonstraram que o nitrato foi quase totalmente consumido, em ambas as condições nutricionais avaliadas, em período superior a 100 horas (Figura 9). No entanto, medidas do potencial de oxi-redução não haviam sido realizadas nesses ensaios, o que impossibilitou o controle das condições anóxicas requeridas para que a desnitrificação se estabelecesse. Os valores das concentrações de nitrato medidas neste ensaio estão apresentados no Apêndice B.

Sabe-se que, para ocorrer a desnitrificação, se fazem necessárias condições anóxicas, nas quais o potencial de oxi-redução do meio de cultivo esteja em torno de +100mV a -100mV (Zhender, 1988).

Segundo Zehnder (1988), organismos desnitrificantes são basicamente aeróbios com capacidade alternativa de reduzir óxidos de nitrogênio quando o oxigênio se torna limitante. Além disso, o crescimento destes microrganismos é mais favorecido quando o meio de cultivo é inicialmente aeróbio. Desta forma, os microrganismos aeróbios presentes no meio irão consumir o oxigênio presente e, gradualmente, permitir que a cultura altere seu metabolismo para a desnitrificação. Ainda, se um inóculo aeróbio for transferido para meio anaeróbio estrito, o crescimento poderá ser lento ou até impedido de ocorrer devido à inabilidade do inóculo em gerar energia para sintetizar as enzimas 
necessárias para a desnitrificação. Isto pode explicar o elevado tempo observado para o consumo do nitrato nos ensaios de enriquecimentos do presente trabalho. A medida do potencial redox foi de $-363,9 \mathrm{mV}$ para o meio Zinder e $-412,1 \mathrm{mV}$ para o meio Dolfing; ou seja, potenciais favoráveis ao metabolismo anaeróbio estrito. A condição anaeróbia explica, também, a presença de metano no headespace dos reatores e a observação freqüente de morfologias sugestivas de arquéias metanogênicas.

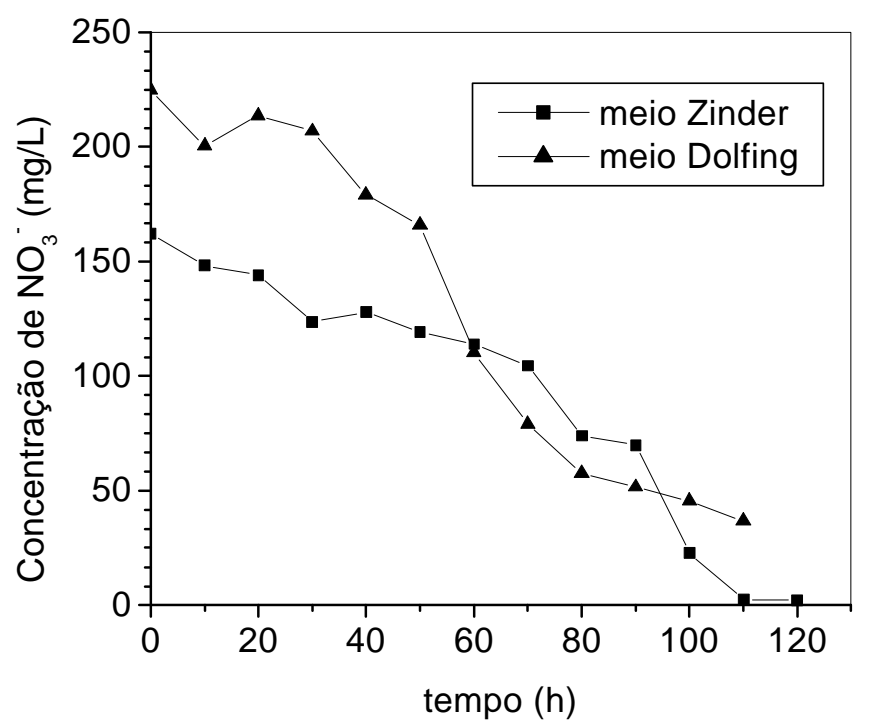

Figura 9 - Variação temporal da concentração média de nitrato $\left(\mathrm{N}-\mathrm{NO}_{3}{ }^{-}\right)$nos reatores em batelada alimentados com meio Zinder e Dolfing.

Desse modo, as condições de cultivos propostas por Zinder e Dolfing foram modificadas, com a finalidade de favorecer o crescimento dos organismos desnitrificantes e, conseqüentemente, utilização de nitrato em menor tempo. Para tanto, foi retirada a solução redutora de sulfeto de sódio proposta pelos autores. A medida do potencial de oxi-redução do meio, nestas novas condições, e sem que o lodo tivesse sido adicionado, demonstrou valores positivos, ou seja, favorável aos microrganismos facultativos (Tabela 15). Imediatamente após a primeira leitura, o lodo foi adicionado ao meio e o valor do potencial de oxi-redução foi se modificando de positivo para negativo com o passar do tempo. Tal procedimento foi favorável e novos ensaios foram, então, realizados na ausência da solução redutora, mantendo-se a troca da atmosfera gasosa, específica para cada condição nutricional (Zinder e Dolfing), por cerca de 5 minutos. 
Tabela 15 - Valores dos potenciais redox dos reatores em batelada alimentados com meios Zinder e Dolfing, após modificação das condições de alimentação.

\begin{tabular}{ccc}
\hline Meio de cultivo & $\begin{array}{c}\text { Tempo } \\
\text { (minutos) }\end{array}$ & $\begin{array}{c}\text { Potencial redox } \\
(\mathrm{mV})\end{array}$ \\
\hline Meio Zinder & 0 & $+296,6^{*}$ \\
& 12 & 0,0 \\
& 24 & $-42,1$ \\
& 30 & $-60,0$ \\
Meio Dolfing & 0 & $+234,2^{*}$ \\
& 5 & $+116,4$ \\
& 15 & 0,0 \\
& 27 & $-19,1$ \\
& 30 & $-52,5$ \\
\hline
\end{tabular}

*potencial redox medido antes da adição do lodo. Os outros valores foram obtidos após a adição do lodo

Uma vez que as condições anóxicas foram acertadas para favorecer o crescimento de microrganismos desnitrificantes, novos ensaios de avaliação do consumo de nitrato $\left(\mathrm{N}-\mathrm{NO}_{3}{ }^{-}\right)$foram realizados. Os resultados obtidos estão representados na Figura 10 e Apêndice B.

Os ensaios de desnitrificação demonstraram que tanto no meio Zinder, quanto no meio Dolfing, o nitrato foi eficientemente consumido. Utilizando-se as médias dos ensaios em triplicatas, de cada condição nutricional estudada, a eficiência na utilização do nitrato foi de 98,9\% em meio Zinder (em 14 horas) e de 99,8\% em meio Dolfing (em 12 horas), para concentração média inicial de nitrato de 146,8 mg/L. Estes resultados demonstraram que as duas condições testadas foram favoráveis ao desenvolvimento de microrganismos capazes de realizar a desnitrificação.

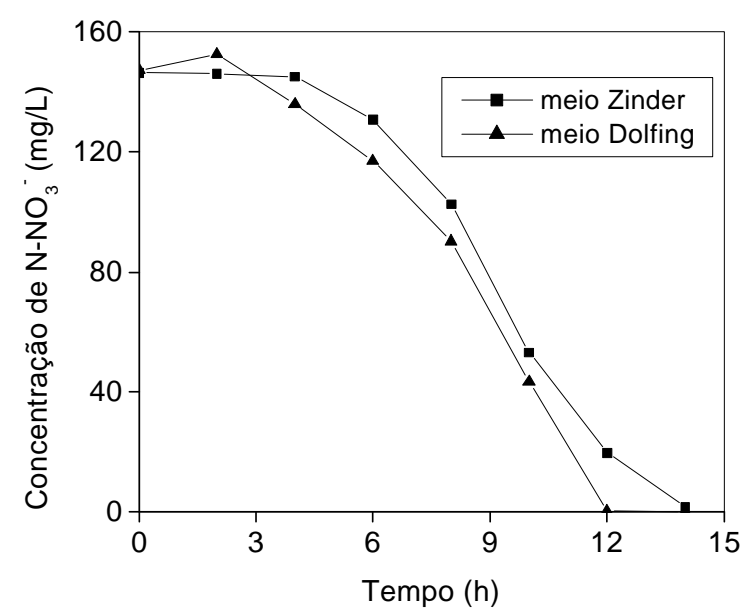

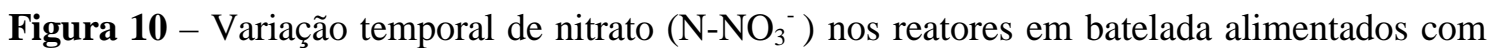
os meios Zinder e Dolfing, modificados 
Durante a fase desnitrificante, observou-se, em ambos os meios de cultivo, o predomínio de bacilos, bacilos em cadeia e cocos (Figuras 11 e 12).

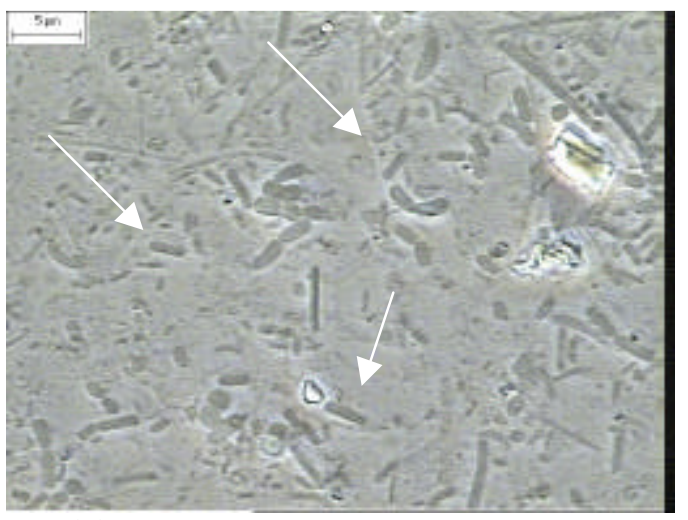

(a)

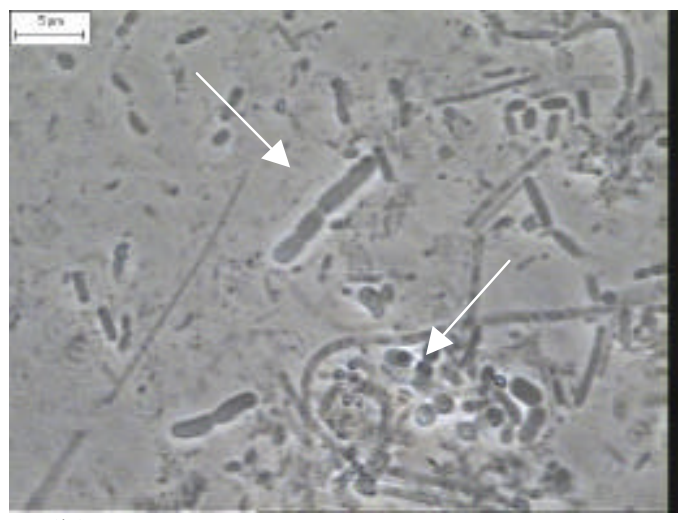

(b)

Figura 11 - Microscopia de contraste de fase das amostras obtidas ao final da batelada do reator alimentado com meio Zinder modificado: (a) bacilos, (b) bacilos em cadeia e cocos. 1500X

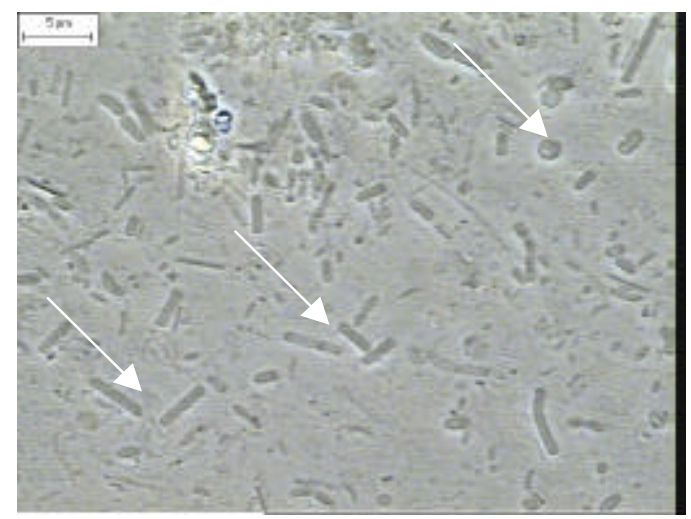

(a)

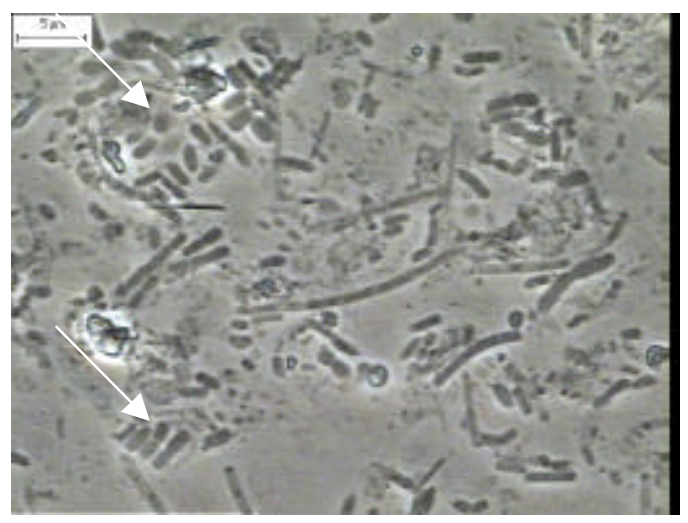

(b)

Figura 12 - Microscopia de contraste de fase das amostras obtidas ao final da batelada do reator alimentado com meio Dolfing modificado: (a) bacilos e cocos, (b) bacilos em cadeia, cocobacilos, cocos, bacilos curvos. 1500X

Com o esgotamento do nitrato, condições anaeróbias se estabelecem favorecendo o metabolismo metanogênico. Nestas condições, a metanogênese pode ocorrer a partir do hidrogênio que reduz o dióxido de carbono a metano (metanogênese hidrogenotrófica), ou ainda, pela conversão de acetato a metano (metanogênese acetotrófica) (Madigan et al., 1997). Nos ensaios realizados com os dois meios de cultivo modificados, a produção de metano ocorreu somente após a estabilização da redução do nitrato, atingindo, em média, 24\%, após 190 horas de incubação. Arquéias metanogênicas semelhantes a Methanosaeta sp. e Methanosarcina sp. (organismos acetotróficos), bem como bacilos fluorescentes (organismos hidrogenotróficos) foram observados com freqüência na fase metanogênica dos reatores alimentados com meio 
Dolfing e Zinder (Figura 13). Estes microrganismos podem ter se beneficiado da presença do acetato presente no meio. A leitura do potencial de oxi-redução dos reatores, após 190 horas de operação, registrou valores próximos de $-344 \mathrm{mV}$, confirmando o estabelecimento do potencial favorável ao crescimento das metanogênicas.

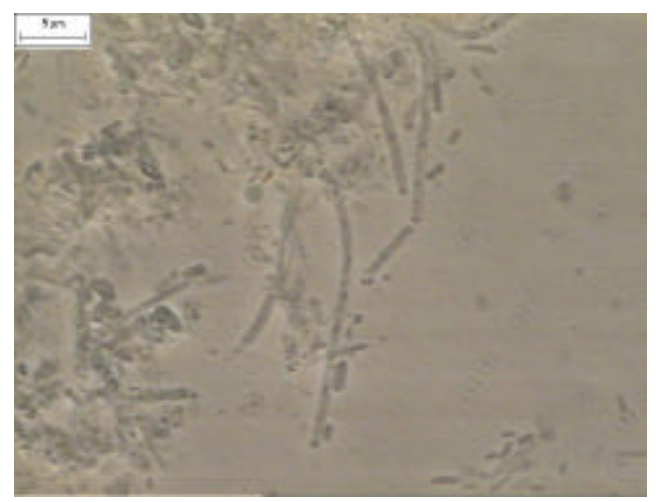

(a)

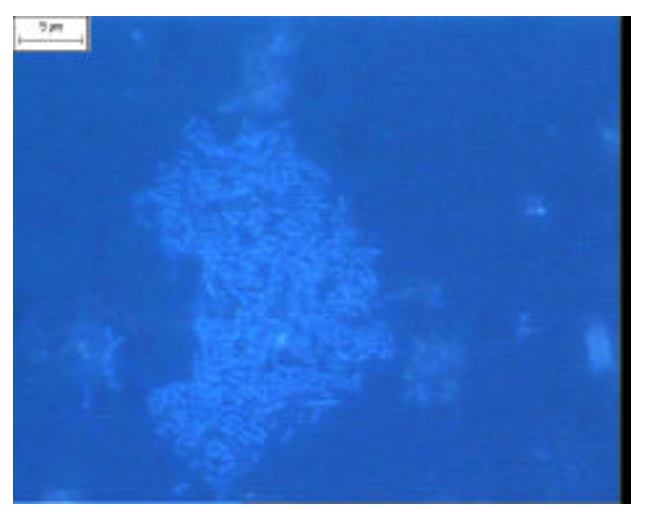

(c)

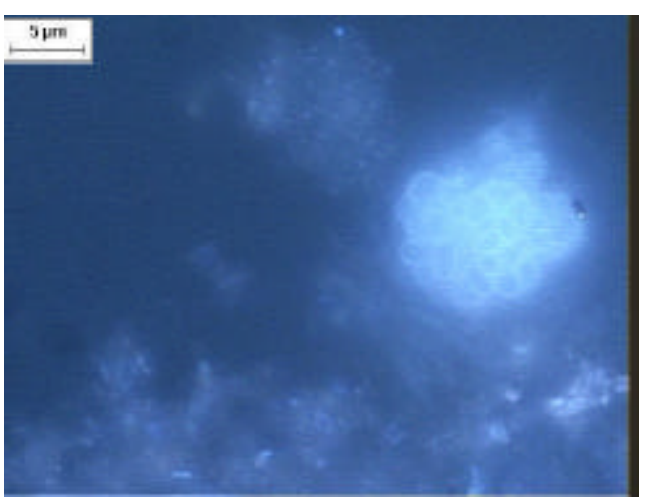

(b)

Figura 13- Microscopia de contraste de fase e fluorescência de amostras dos reatores em batelada alimentados com meio Zinder e meio Dolfing: (a) células semelhantes a Methanosaeta sp. (b) células semelhantes a Methanosarcina $s p$. e (c) bacilos fluorescentes. $1500 \mathrm{X}$

Embora as duas condições nutricionais testadas tenham sido satisfatórias para o crescimento de bactérias desnitrificantes, o meio Dolfing foi escolhido para dar continuidade aos ensaios de isolamento das culturas por apresentar composição mais simples, não necessitando do acréscimo de vitaminas, e favorecer ligeiramente o consumo de nitrato em relação ao meio Zinder.

\subsection{Purificação do inóculo}

Uma vez que a melhor condição nutricional para o crescimento dos microrganismos desnitrificantes foi determinada, realizou-se a purificação desta cultura.

$\mathrm{Na}$ fase de purificação do inóculo, foi observada ampla diversidade morfológica no lodo. A purificação foi realizada em presença de cada um dos hidrocarbonetos, 
separadamente. Os melhores resultados destas purificações foram aqueles obtidos com benzeno $(10 \mathrm{mg} / \mathrm{L})$ e etilbenzeno $(10 \mathrm{mg} / \mathrm{L})$, ou seja, em presença destes compostos, houve maior seletividade em relação à diversidade morfológica e, portanto, melhor purificação do inóculo. (Figura 14).

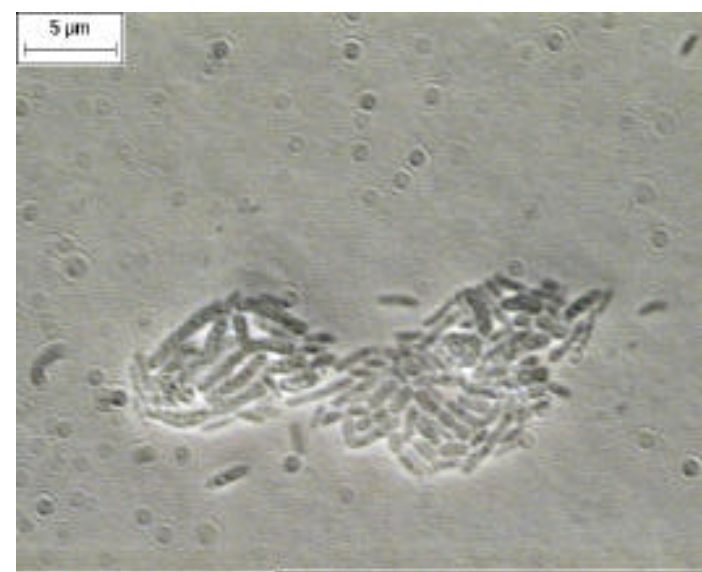

(a)

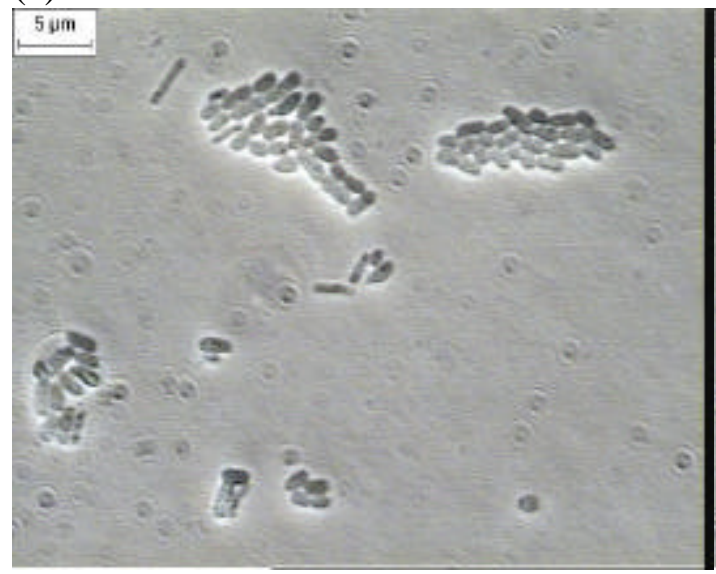

(c)

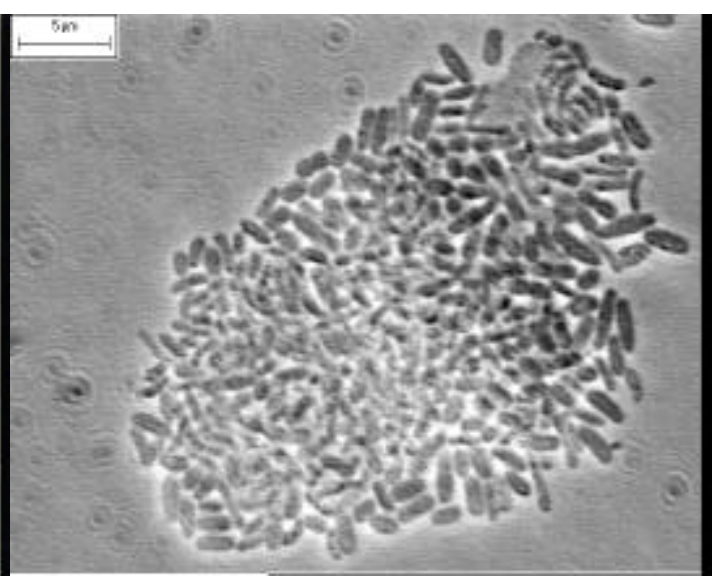

(b)

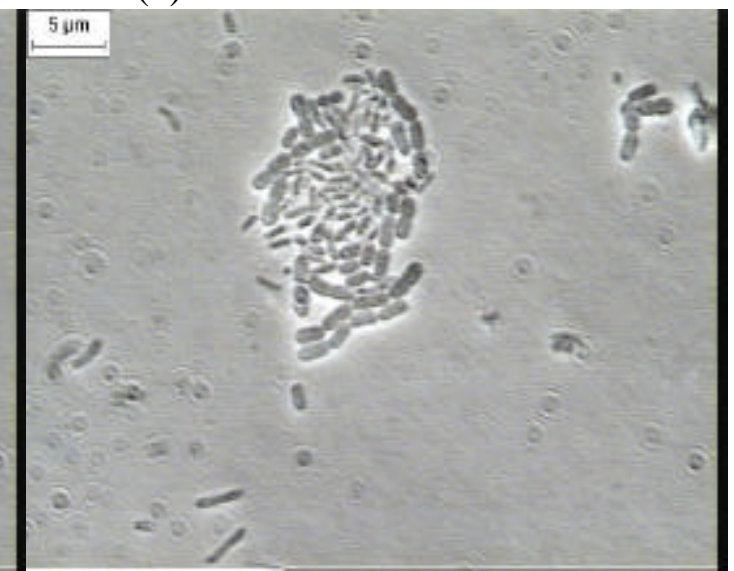

(d)

Figura 14- Microscopia de contraste de fase das morfologias observadas na fase de purificação do inóculo em presença de benzeno $\left(\mathrm{a}, \mathrm{b}-\right.$ diluição $10^{-5}$ ) e etilbenzeno $\left(\mathrm{c}, \mathrm{d}-\right.$ diluição $10^{-5}$ ). $1500 \mathrm{X}$

Com o objetivo de se obter resultado ainda mais satisfatório, as culturas purificadas em presença de benzeno e etilbenzeno foram submetidas à purificação em placa de Petri. A microscopia de cada uma das colônias isoladas em placa demonstrou que, embora houvesse predomínio de células com morfologia de cocobacilos, outras morfologias também podiam ser observadas. Na tentativa de se obter culturas ainda mais selecionada, especialmente em presença de benzeno, as colônias obtidas foram, por mais 2 vezes, transferidas para meio líquido fresco, incubadas e, novamente, plaqueadas. Após o terceiro repique, foram observados, predominantemente, cocos (diplococos) e cocobacilos. Todavia, mais raramente, outras morfologias, tais como 
bacilos e filamentos foram observadas (Figura 15). Este resultado indicou que as culturas não estavam totalmente puras, podendo se tratar de uma associação positiva, conhecida como co-cultura, onde os microrganismos envolvidos estariam se beneficiando do subproduto da degradação do outro para crescer.

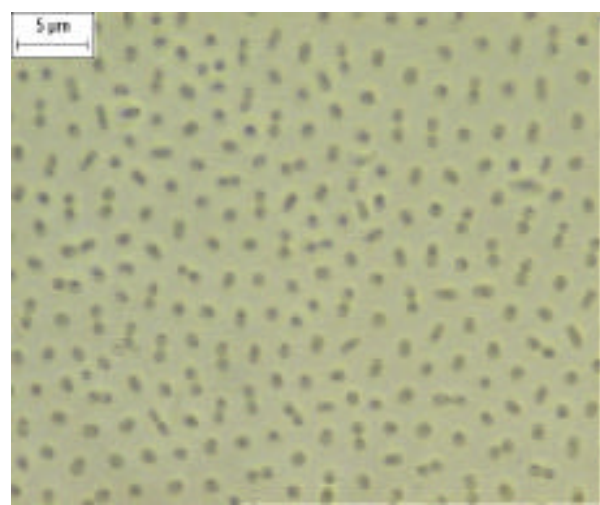

(a)

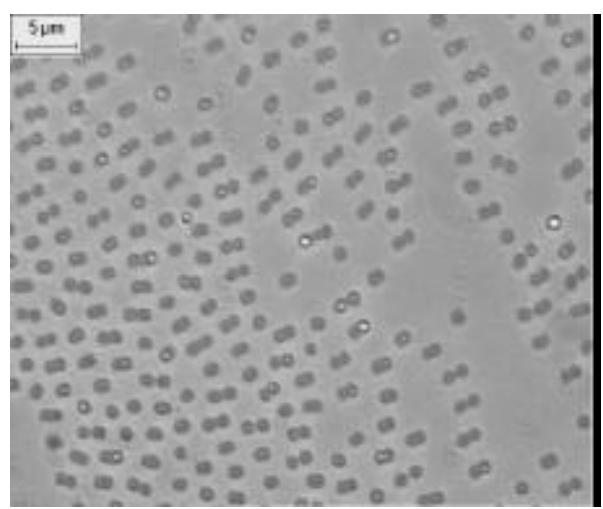

(b)

Figura 15 - Microscopia de contraste de fase. Morfologias predominantes nos isolamentos em placas de Petri em presença de (a) benzeno $(10 \mathrm{mg} / \mathrm{L})$ e (b) etilbenzeno $(10 \mathrm{mg} / \mathrm{L}) .1500 \mathrm{X}$

No crescimento em placa de Petri, as colônias isoladas apresentaram as seguintes características: superfície lisa, consistência cremosa, forma convexa e cor branco-leitosa (Figura 16).

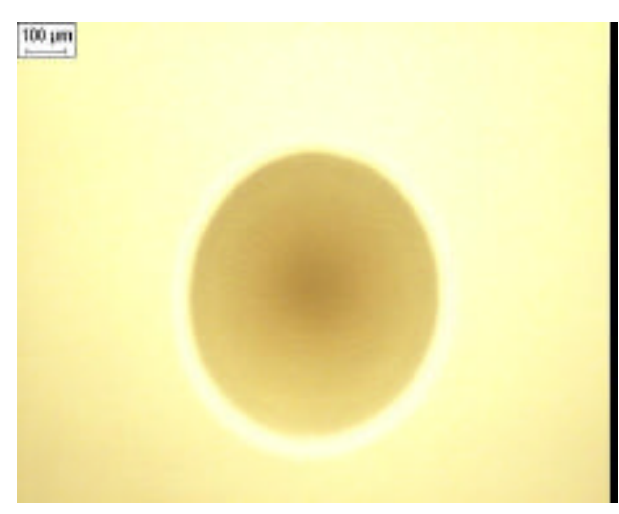

(a)

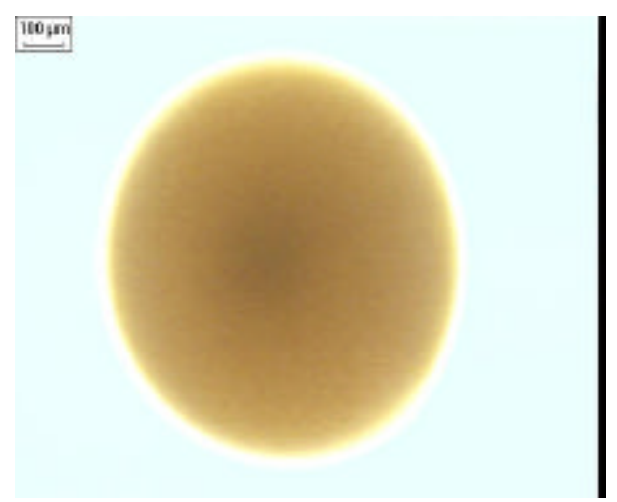

(b)

Figura 16 - Colônias obtidas do isolamento nos meios contendo (a) benzeno e (b) etilbenzeno.

A coloração de Gram demonstrou que as células isoladas, nas duas condições (benzeno e etilbenzeno) eram Gram-negativas (Figura 17). 


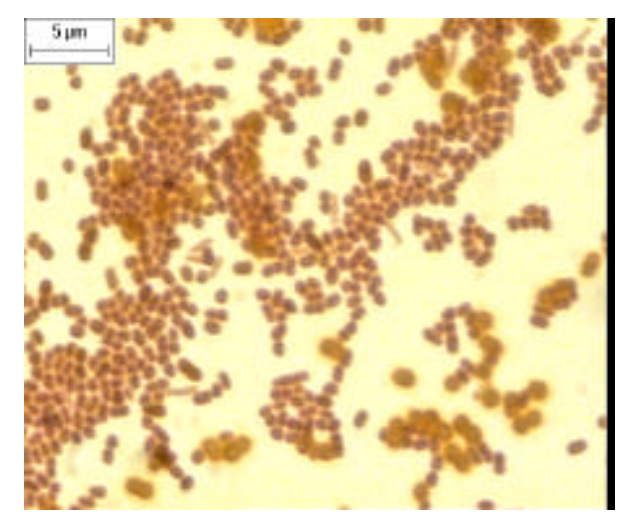

(a)

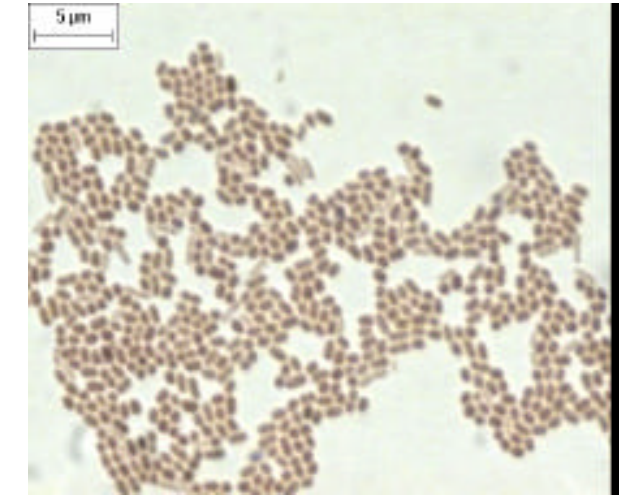

(b)

Figura 17- Células Gram negativas, isoladas em (a) benzeno e (b) etilbenzeno. 1500X

No interior destas células, grânulos escuros, provavelmente substância de reserva, foram observados (Figura 18).

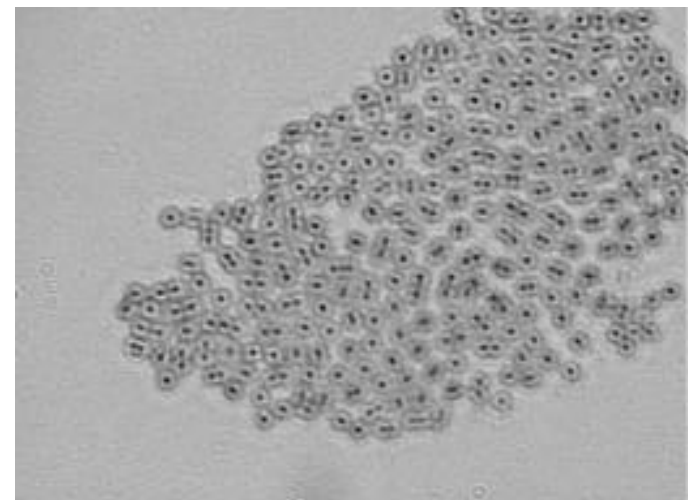

Figura 18 - Microscopia de contraste de fase dos grânulos intracelulares observados nas células isoladas em etilbenzeno. 1500X

\section{4 - Confirmação do metabolismo desnitrificante}

Outro aspecto relevante aos compostos nitrogenados está relacionado com conhecimento da rota metabólica atuante no sistema biológico. Sabe-se que a redução do nitrato em ambientes anóxicos pode se dar por dois processos: (1) desnitrificação, ou (2) redução desassimilativa do nitrato a amônia (RDNA) (Tiedje, 1988). Na desnitrificação, o processo da redução do nitrato a nitrogênio gasoso ocorre de acordo com as seguintes etapas:

$\mathrm{NO}_{3}{ }^{-} \rightarrow \mathrm{NO}_{2}{ }^{-} \rightarrow \mathrm{NO} \rightarrow \mathrm{N}_{2} \mathrm{O} \rightarrow \mathrm{N}_{2}$

Neste processo, 5 elétrons são gastos para que a desnitrificação seja completa. Os microrganismos oxidam um substrato e os equivalentes gerados são transferidos para o 
nitrato, que age como aceptor final de elétrons na cadeia respiratória. Em consequiência, para que a desnitrificação se estabeleça, é necessário a presença de um substrato oxidável e concentração adequada de nitrato.

$\mathrm{Na}$ redução desassimilativa de nitrato a amônia são requeridos 8 elétrons e o processo ocorre de acordo com as seguintes etapas:

$$
\mathrm{NO}_{3}{ }^{-} \rightarrow \mathrm{NO}_{2}{ }^{-} \rightarrow \mathrm{NH}_{4}{ }^{+}
$$

De acordo com Tiedje (1988), o desenvolvimento da população de microrganismos responsáveis pela RDNA ocorre como resultado da competição entre o metabolismo fermentativo e respiratório. O principal fator que afeta a competição entre bactérias desnitrificantes e produtoras de amônia é a proporção entre doador e aceptor de elétrons disponíveis. Em termos gerais, a RDNA ocorre quando há elevada relação C/N, já que, em condições de limitação de aceptor de elétrons, é a via que permite a eliminação de maior número de elétrons. Por outro lado, quando há limitação de substrato, a desnitrificação é favorecida, uma vez que esta via permitirá a obtenção de maior quantidade de energia por mol de substrato consumido.

Diversos estudos abordam a discussão a respeito de relações $\mathrm{C} / \mathrm{N}$ procurando estabelecer valor ótimo para a desnitrificação. Todavia, enquanto relações na faixa entre 0,9 a 1,7, foram relatadas como sendo ótimas para promover de forma adequada o processo de desnitrificação (Callado, 2001; Santos, 2004), valores mais altos foram, também, sugeridos indicando desnitrificação favorável. De acordo com o estudo de Houbron et al. (1999), a relação $\mathrm{C} / \mathrm{N}$, para a desnitrificação, deve ser de aproximadamente 3. No entanto, valores entre 6 e 7 foram utilizados com sucesso em outros estudos (Shieh e Mulcahy, 1986; Pochana e Keller, 1999). Relações C/N iguais a 5,5; 4,5; 4,0 e 2,6, foram recomendadas no estudo de Chiu e Chung (2003), para concentrações de $\mathrm{N}^{-\mathrm{NO}_{3}}$ de 25, 50, 100 e $200 \mathrm{mg} / \mathrm{L}$, respectivamente, utilizando-se acetato de sódio como doador de elétrons. Entretanto, o estudo menciona que sistemas biológicos semelhantes podem ter diferentes relações $\mathrm{C} / \mathrm{N}$. Desta forma, os autores sugerem que a relação $\mathrm{C} / \mathrm{N}$ ótima deve ser determinada experimentalmente para sistemas desnitrificantes, utilizados em tratamentos específicos de águas residuárias.

No enriquecimento realizado no estudo de Dolfing et al. (1990) foi utilizado tolueno $(18,4 \mathrm{mg} / \mathrm{L})$, como única fonte de carbono, enquanto que a massa total de nitrogênio foi de $170 \mathrm{mg} / \mathrm{L}$, correspondendo a relação $\mathrm{C} / \mathrm{N}$ de 5,2. Desse modo, o presente trabalho adotou a relação $\mathrm{C} / \mathrm{N}$ de 5,1, baseando-se no estudo destes autores, e procurando atender a teoria proposta por Tiedje (1988), o qual sugere a ocorrência da desnitrificação com 
limitação do substrato em relação ao aceptor de elétrons. Para tanto, foi adicionado ao meio, aproximadamente, $0,72 \mathrm{~g}$ de carbono, correspondente a $20 \mathrm{mM}$ de acetato de sódio e $10 \mathrm{mM}$ de etanol, e $0,14 \mathrm{~g}$ de nitrogênio equivalente a $10 \mathrm{mM}$ de nitrato de sódio.

A metodologia do bloqueio por acetileno foi realizada para confirmar a ocorrência da desnitrificação pelas células do presente estudo. Esta metodologia baseia-se no princípio de que o acetileno, sendo estruturalmente semelhante ao óxido nitroso, bloqueia a redução do óxido nitroso que, por sua vez, acumula-se estequiometricamente a partir de nitrato ou nitrito (Zehnder, 1988). Como a desnitrificação é caracterizada pelas transformações de $\mathrm{NO}_{3}{ }^{-}$ou $\mathrm{NO}_{2}{ }^{-}$a $\mathrm{N}_{2} \mathrm{O}$ e este a $\mathrm{N}_{2}$, o acúmulo de óxido nitroso é um critério que identifica a desnitrificação. Os resultados obtidos nos ensaios onde acetileno foi adicionado demonstraram que houve acúmulo de óxido nitroso no headspace dos reatores avaliados (Figura 19) (Apêndice C).

De acordo com Zehnder (1988), um dos problemas da metodologia do bloqueio pelo acetileno é que a difusão do gás pode ser restrita, o que pode limitar a dispersão do acetileno e a recuperação de óxido nitroso, ou ainda, o acetileno pode não ser capaz de bloquear completamente a redução do óxido nitroso. Estas observações podem explicar a formação não estequiométrica do óxido nitroso.

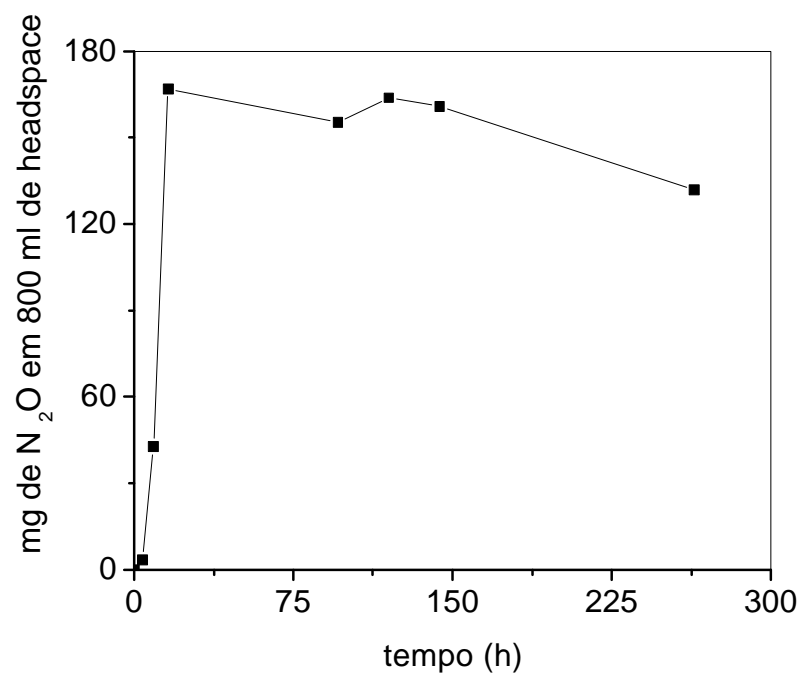

Figura 19 - Acúmulo de óxido nitroso observado no reator com acetileno.

Além disso, a quantificação de $\mathrm{N}^{-\mathrm{NH}_{4}}{ }^{+}$foi analisada com a finalidade de comprovar que a redução desassimilativa de nitrato a amônia não estava sendo realizada. Neste ensaio, foram observados $57,8 \mathrm{mg} / \mathrm{L}$ de $\mathrm{N}_{-} \mathrm{NH}_{4}{ }^{+}$, no início do experimento, e 20,3 mg/L de $\mathrm{N}_{-} \mathrm{NH}_{4}{ }^{+}$ao final da batelada (Apêndice D). Com estes 
resultados, constatou-se que a desnitrificação era o metabolismo realizado pelas células da cultura purificada.

\subsection{Caracterização nutricional das culturas}

As culturas isoladas foram, também, caracterizadas em relação à versatilidade metabólica das células em utilizar diferentes substratos, sob diferentes condições (desnitrificante, fermentativa e sulfetogênica).

Embora vários trabalhos apresentem caracterização nutricional com $1 \mathrm{mM}$ de substrato orgânico (Schocher et al., 1991; Rabus e Widdel, 1995; Zhou et al.,1995), esta concentração demonstrou ser insuficiente para promover o crescimento adequado das células deste trabalho. Por este motivo novo ensaio foi realizado utilizando-se $10 \mathrm{mM}$ de cada substrato.

Crescimento celular não foi observado nos ensaios realizados sob condições sulfetogênicas, para todos os substratos avaliados. Exames microscópicos demonstraram a presença de "debris", sugerindo possível toxicidade do sulfato para a cultura, e confirmando a inabilidade das mesmas em realizar o metabolismo sulfetogênico.

De forma geral, as duas culturas apresentaram resultados semelhantes em relação à versatilidade de utilização dos substratos. No entanto, as melhores respostas de crescimento foram obtidas para a cultura isolada em benzeno. As microscopias realizadas para os ensaios referentes à cultura isolada em etilbenzeno demonstram células morfologicamente menores quando comparadas àquelas observadas nos ensaios

com a cultura isolada em benzeno. É possível que o inóculo utilizado nos ensaios tenha sofrido algum prejuízo, comprometendo a qualidade da biomassa e, conseqüentemente, melhores resultados nos ensaios com esta cultura.

Dos substratos avaliados, houve crescimento em presença de lactato, glicose, etanol, propionato, butirato, benzoato, piruvato, acetato e dos hidrocarbonetos (benzeno, tolueno, etilbenzeno e $p$-xileno) solubilizados em etanol. De forma geral, as melhores respostas de crescimento foram obtidas em lactato, glicose, etanol, propionato e em presença dos hidrocarbonetos. Em acetato, a cultura isolada em benzeno apresentou crescimento bem mais expressivo, quando comparada com a cultura isolada em etilbenzeno, no entanto, este resultado pode estar relacionado à qualidade do inóculo, conforme comentado anteriormente. 
Os únicos substratos que não foram utilizados pelas culturas, em nenhuma das condições avaliadas, foram fenol e metanol.

As melhores respostas de crescimentos foram obtidas sob condições desnitrificantes (Figura 20). Em condições fermentativas, a absorbância apresentou valores baixos (Figura 21). Os valores das absorbâncias medidas neste ensaio estão apresentados no Apêndice E.

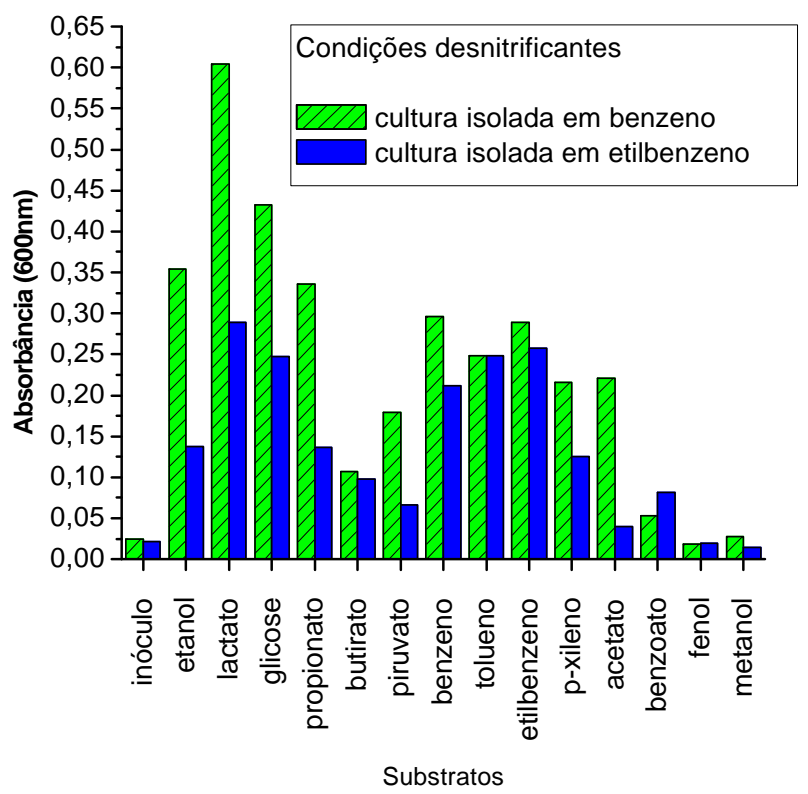

Figura 20 - Crescimento em diferentes substratos para as culturas isoladas em presença de benzeno e etilbenzeno, sob condições desnitrificantes.

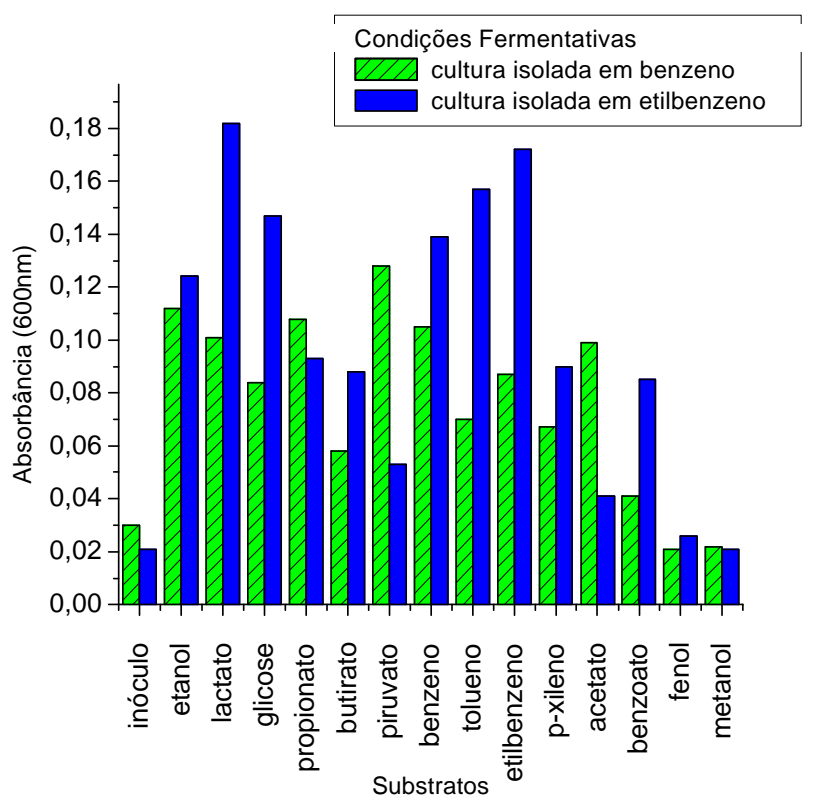

Figura 21 - Crescimento em diferentes substratos para as culturas isoladas em presença de benzeno e etilbenzeno, sob condições fermentativas. 
A microscopia referente aos ensaios realizados sob condições fermentativas revelou a presença de células com morfologia diferenciada (bacilos finos) daquelas que predominaram nos ensaios realizados sob condições desnitrificantes (cocobacilos) (Figura 22). A baixa representatividade de bacilos finos, sob condições desnitrificantes, pode estar relacionada à inibição dos mesmos para esta condição.

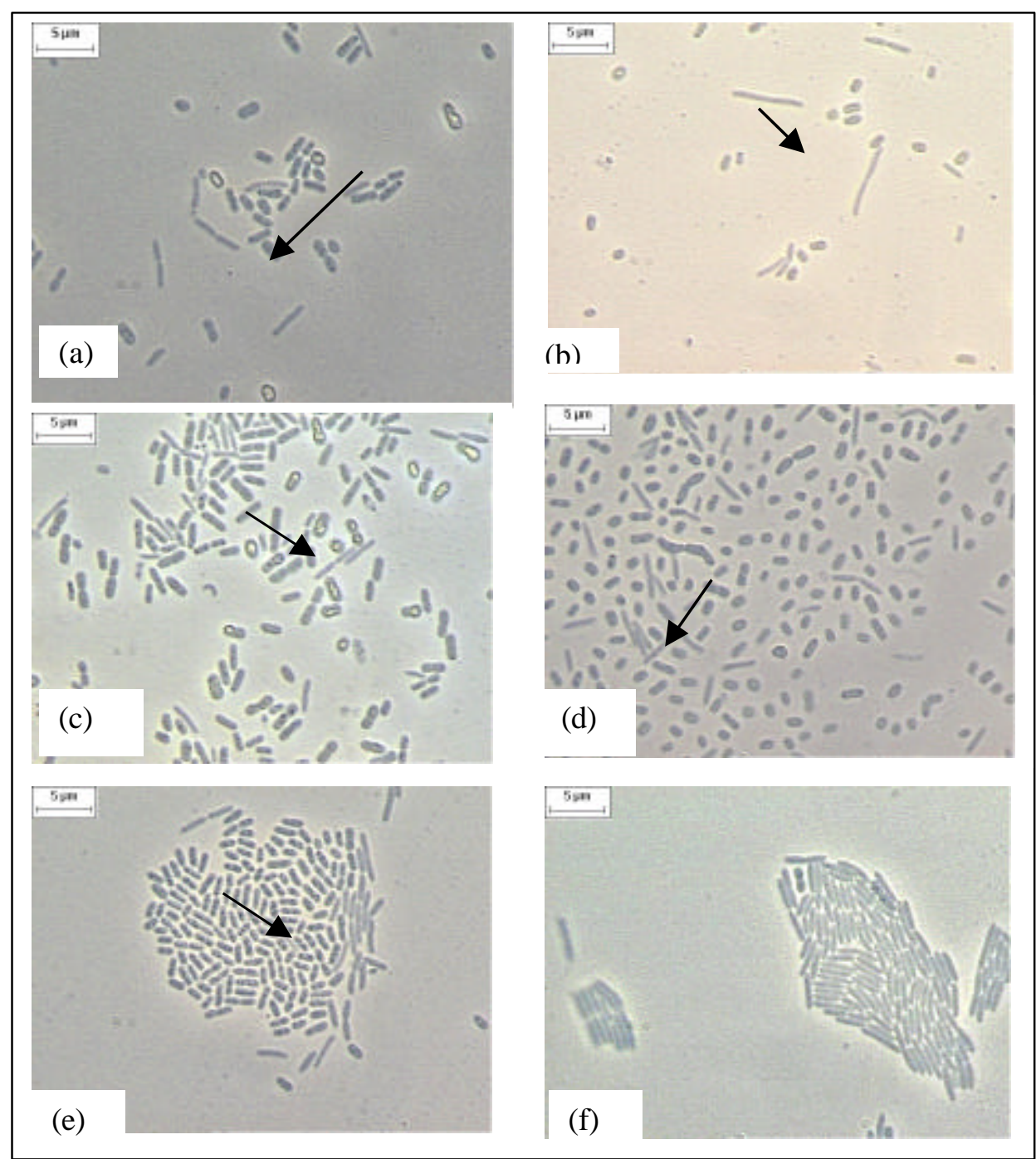

Figura 22 - Microscopia de contraste de fase das morfologias observadas durante o monitoramento do ensaio de caracterização nutricional sob condições fermentativas. As setas indicam bacilos observados no crescimento com: (a) acetato, (b) glicose, (c) propionato, (d) butirato, (e) etanol e (f) lactato.

Por outro lado, bacilos finos foram raramente observados nos ensaios fermentativos onde os hidrocarbonetos estavam solubilizados em etanol (Figura 23). Esta observação indica que o crescimento destes bacilos pode ter sido inibido pela presença dos hidrocarbonetos. Nesta condição, morfologias características da condição desnitrificantes voltaram a predominar. Considerando-se que células desnitrificantes são 
facultativas, ou seja, também realizam o metabolismo aeróbio, é possível que a presença de traços de oxigênio possa ter favorecido o crescimento destas células, nesta condição.

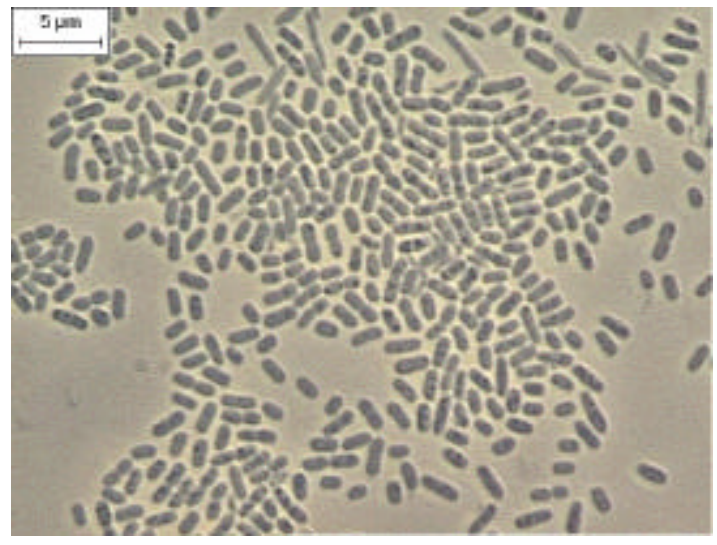

(a)

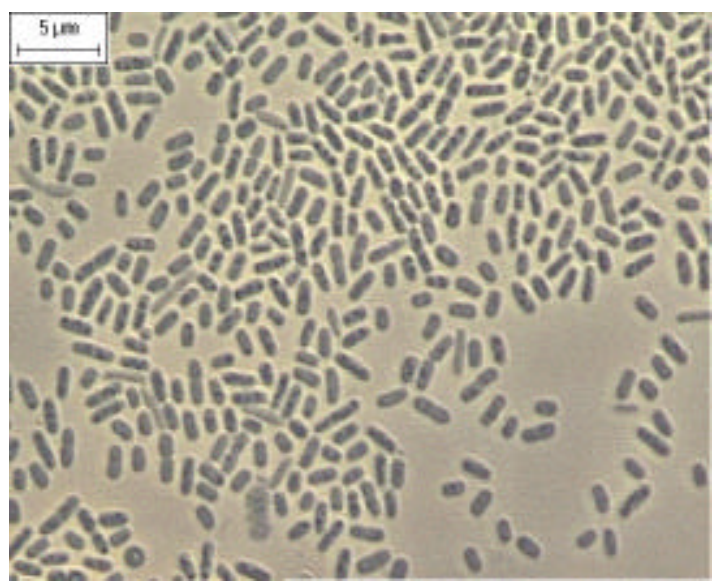

(c)

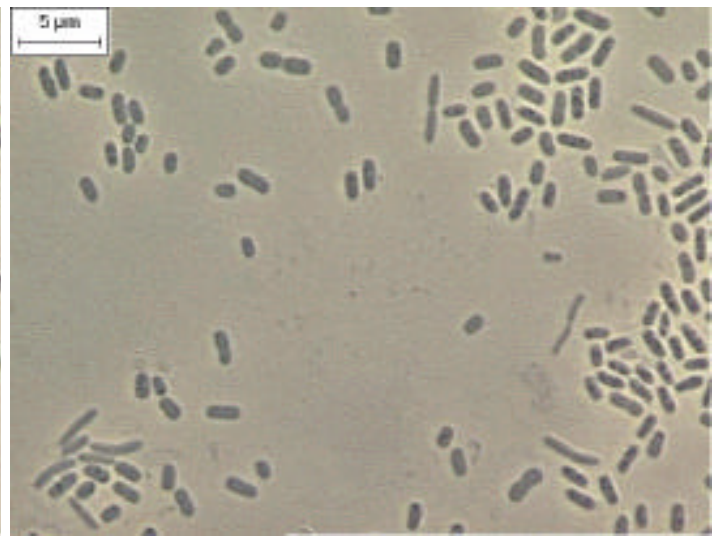

(b)

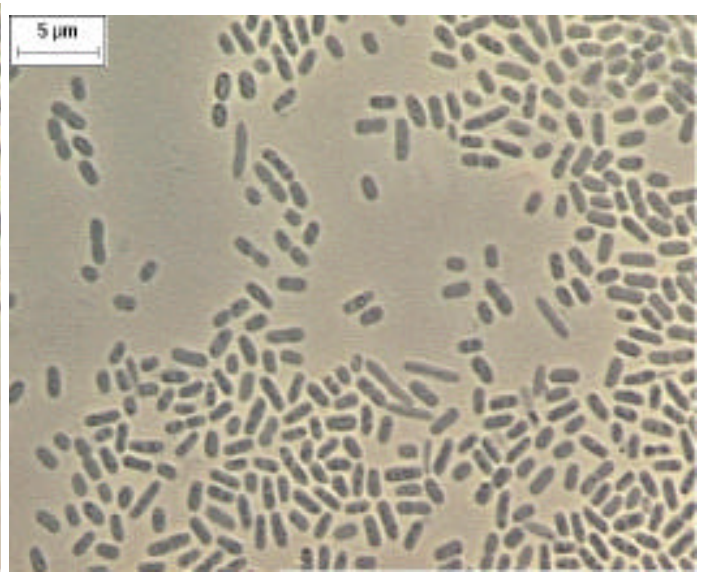

(d)

Figura 23 - Bacilos com extremidades arredondadas, em presença de benzeno (a), tolueno (b), etilbenzeno e (d) $p$-xileno, sob condições fermentativas.

Bacilos, formando arranjo celular característico, foram observados em presença de lactato, sob condições fermentativas (Figura 24).
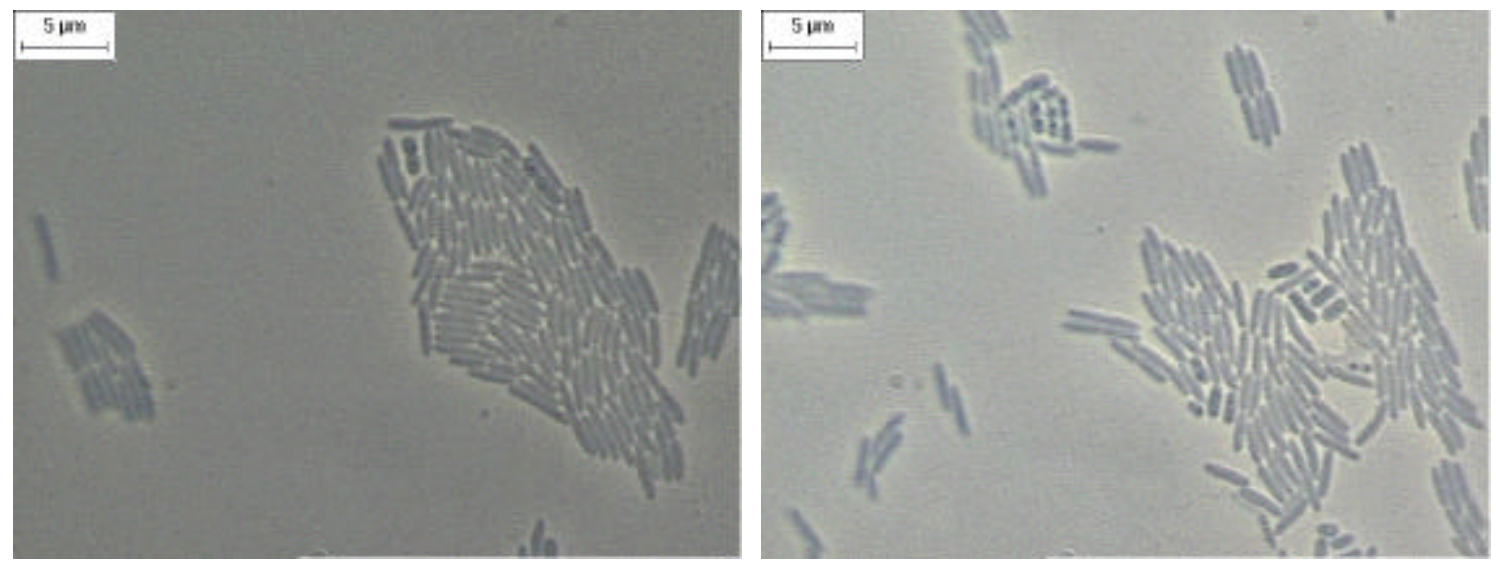

Figura 24 - Microscopia de contraste de fase da cultura em meio contendo lactato (10mM), em condição fermentativa. 
Os resultados dos exames microscópicos obtidos na caracterização nutricional da cultura confirmam, mais uma vez, que a cultura purificada constitui-se de diferentes morfologias que predominam conforme as condições do meio.

\subsection{Determinação do tempo de geração das culturas}

O tempo de geração em pesquisas microbiológicas é utilizado como indicador do estado fisiológico de uma população de células e é freqüentemente usado para testar os efeitos positivos ou negativos de determinados tratamentos em culturas bacterianas. Assim, o conhecimento de como determinada população microbiana pode rapidamente se expandir é muito útil na determinação de métodos de controle desta população. Diversos trabalhos realizados com microrganismos capazes de utilizar hidrocarbonetos aromáticos avaliaram o tempo de geração das culturas puras envolvidas na degradação destes compostos. Nakagawa et al. (2002) relatou que em geral bactéria redutora de sulfato, capaz de degradar hidrocarbonetos aromáticos cresce vagarosamente, por exemplo, o tempo de geração para a linhagem oXyS1 em $o$-xileno foi 75 horas, 55 horas para a linhagem mXyS1 em $m$-xileno, 36 horas para a linhagem PROTL1, e 27 horas para a linhagem Tol2 em tolueno, respectivamente. Tempo de geração menor foi observado nos trabalhos realizados com culturas desnitrificantes capazes de degradar hidrocarbonetos aromáticos. No trabalho de Schocher et al. (1991), a avaliação do crescimento de duas linhagens (T e K172) associadas à degradação de tolueno $(92,0$ $\mathrm{mg} / \mathrm{L}$ ), sob condições desnitrificantes, demonstrou que os tempos de gerações variaram entre 7 e 20 horas. Os tempos de gerações de quatro linhagens desnitrificantes, EbN1, $\mathrm{PbN} 1$, ToN1 e mXyN1, isoladas em etilbenzeno, propilbenzeno, tolueno e $m$-xileno, respectivamente, foram avaliados, no estudo de Rabus e Widdel (1995). Esse estudo demonstrou que o menor tempo de geração da linhagem EbN1 durante o crescimento em etilbenzeno $(31,0 \mathrm{mg} / \mathrm{L})$ foi de 11 horas. Estudos com culturas desta mesma linhagem, com 5\% (v/v) de inóculo, apresentaram crescimento completo em etilbenzeno, em 2 dias. A linhagem ToN1, nas mesmas condições, cresceu em tolueno $(27,6 \mathrm{mg} / \mathrm{L})$ em 1 dia, enquanto que a linhagem $m \mathrm{XyN} 1$ cresceu em $m$-xileno $(31,0$ $\mathrm{mg} / \mathrm{L}$ ) tão rápido quando a linhagem $\mathrm{EbN} 1$. A linhagem $\mathrm{PbN} 1$ requereu de 3-4 dias para crescer em propilbenzeno. No trabalho de Ball et al. (1996) a linhagem denominada 
EB1 cresceu, exponencialmente, em etilbenzeno $(10,6 \mathrm{mg} / \mathrm{L})$, com tempo de geração de 14 horas.

No presente trabalho, o tempo de geração foi calculado para as culturas obtidas em benzeno $(11,5 \mathrm{mg} / \mathrm{L})$ e etilbenzeno $(12,7 \mathrm{mg} / \mathrm{L})$. Os valores médios, das duplicatas de reatores avaliados, demonstraram que os microrganismos cresceram exponencialmente entre 12 e 40 horas de ensaio, a $30^{\circ} \mathrm{C}$. $\mathrm{O}$ crescimento exponencial foi associado ao consumo de nitrato, indicando o metabolismo desnitrificante. (Figura 25). Os valores das absorbâncias, nitrato $\left(\mathrm{N}^{-\mathrm{NO}_{3}}{ }^{-}\right)$e etanol, medidos nestes ensaios, estão apresentados no Apêndice F.

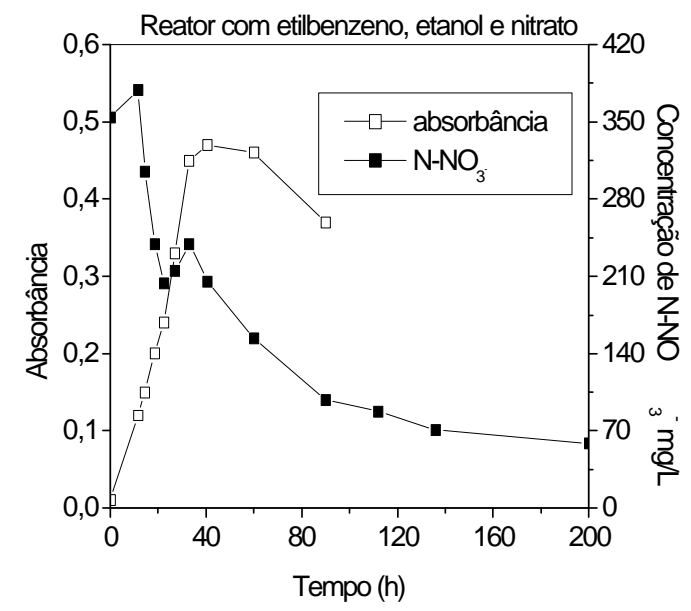

(a)

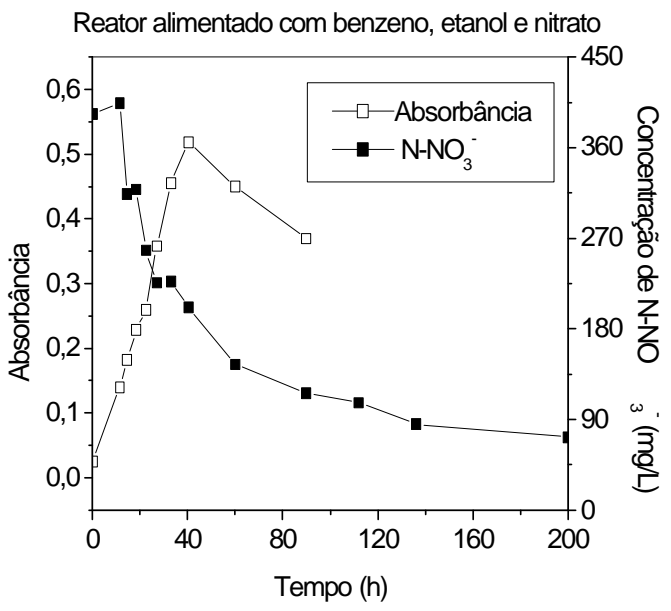

(b)

Figura 25 - Variação temporal do crescimento celular (densidade óptica 600nm) e consumo de nitrato $\left(\mathrm{N}-\mathrm{NO}_{3}{ }^{-}\right)$nos reatores alimentados com (a) etilbenzeno, nitrato e etanol e (b) benzeno, nitrato e etanol.

Velocidades de crescimento $(\mu)$ de $0,046 \mathrm{~h}^{-1}$ e $0,05 \mathrm{~h}^{-1}$ e tempos de geração (tg) de 15,1 horas e 13,9 horas foram obtidos para as células crescidas em benzeno e etilbenzeno, respectivamente (Figura 26). 

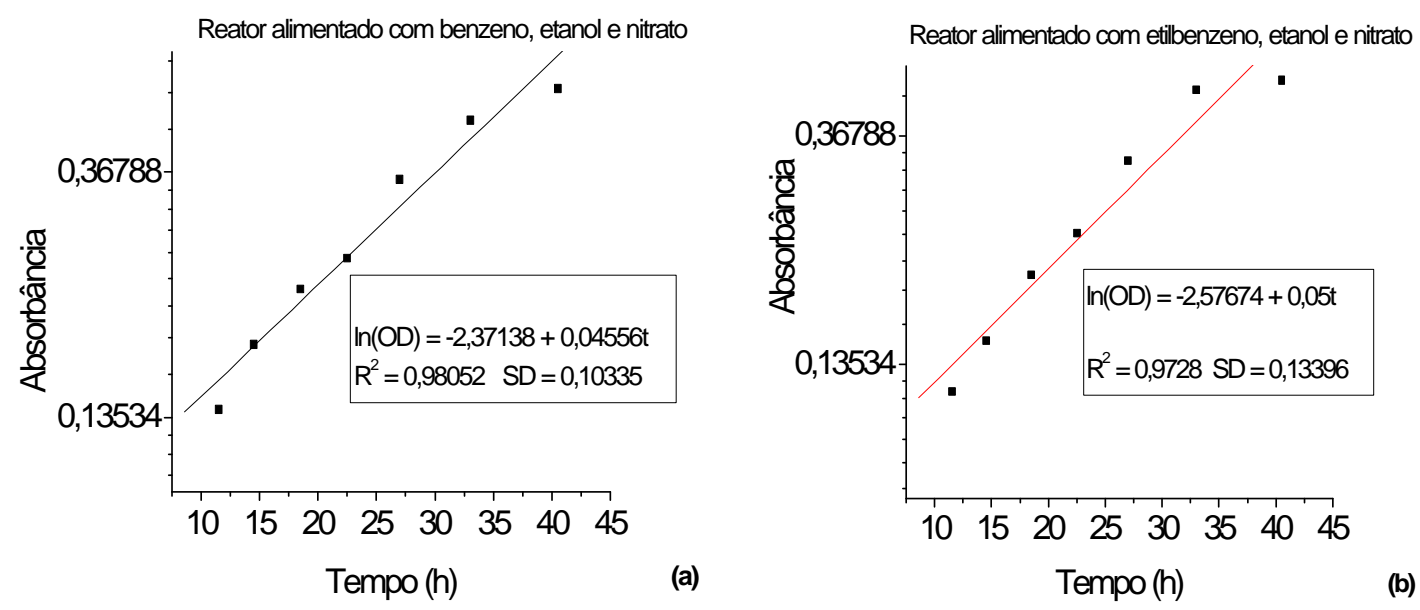

Figura 26 - Representação gráfica da absorbância em função do tempo nos reatores alimentados com (a) benzeno, etanol e nitrato e (b) etilbenzeno, etanol e nitrato.

A avaliação da concentração de etanol no meio reacional dos dois reatores demonstrou que o consumo desta substância foi de 99,4\% e 100\%, nos reatores alimentados com benzeno e etilbenzeno, respectivamente. $\mathrm{O}$ consumo de nitrato $(\mathrm{N}$ $\mathrm{NO}_{3}{ }^{-}$) foi de $81,6 \%$ e $83,4 \%$ nos reatores alimentados com benzeno e etilbenzeno, respectivamente, em 200 horas de ensaio, considerando a concentração inicial média de nitrato $\left(\mathrm{N}-\mathrm{NO}_{3}{ }^{-}\right)$de $373,5 \mathrm{mg} / \mathrm{L}$.

A variação temporal da concentração dos hidrocarbonetos foi também avaliada neste ensaio (Tabela 16). A análise da concentração de benzeno nos reatores demonstrou valores flutuantes, com decaimento inicial, e posterior retorno para valores próximos ao medidos inicialmente. O reator controle (ausência de célula e presença de benzeno, etanol e nitrato) mostrou-se estável, com baixas flutuações na concentração de benzeno. Assim, concluiu-se que o benzeno não foi consumido pelas células do inóculo, durante o tempo de realização do ensaio. A variação da concentração de etilbenzeno, nos reatores utilizados para análise deste composto, variou de forma semelhante ao observado no reator controle (ausência de célula e presença de etilbenzeno), o que inviabilizou a conclusão a respeito da degradação do hidrocarboneto. A variação na concentração de etilbenzeno se deveu, provavelmente, à adsorção no reator, à baixa solubilidade no meio reacional, e/ou à alta volatilidade do hidrocarboneto fazendo com que o mesmo permanecesse no headspace do reator. 
Tabela 16 - Concentrações de benzeno e etilbenzeno nos reatores em batelada.

\begin{tabular}{ccccc}
\hline Tempo & \multicolumn{2}{c}{ Concentração de benzeno (mg/L) } & \multicolumn{3}{c}{ Concentração de etilbenzeno (mg/L) } \\
(h) & Reator c/ células & Reator s/ células & Reator c/ células & Reator s/ células \\
\hline 0 & 11,5 & 9,13 & 12,72 & 11,12 \\
7 & 5,46 & 8,34 & 3,93 & 3,87 \\
15 & 5,7 & 7,21 & 3,30 & 3,87 \\
21 & 8,45 & nd & 4,65 & 5,67 \\
30 & 11,08 & nd & 4,34 & 5,27 \\
48 & 12,1 & 10,2 & 2,02 & 1,56 \\
\hline
\end{tabular}

nd = não determinado

Tempo de geração menor (6,5 horas) foi obtido quando as células isoladas em benzeno foram avaliadas em reatores alimentados somente com etanol e nitrato. Estes resultados indicaram que, provavelmente, a toxicidade proporcionada pela presença do benzeno no meio reacional retardou o crescimento celular da cultura. Entretanto, esta diferença não foi observada para as células isoladas em etilbenzeno, quando foram avaliadas somente em presença de etanol e nitrato, sendo que o tempo de geração foi o mesmo daquele observado para o crescimento em presença de etilbenzeno (13,9 horas) (Figura 27). Os valores das medidas realizadas neste ensaio estão apresentados no Apêndice G.
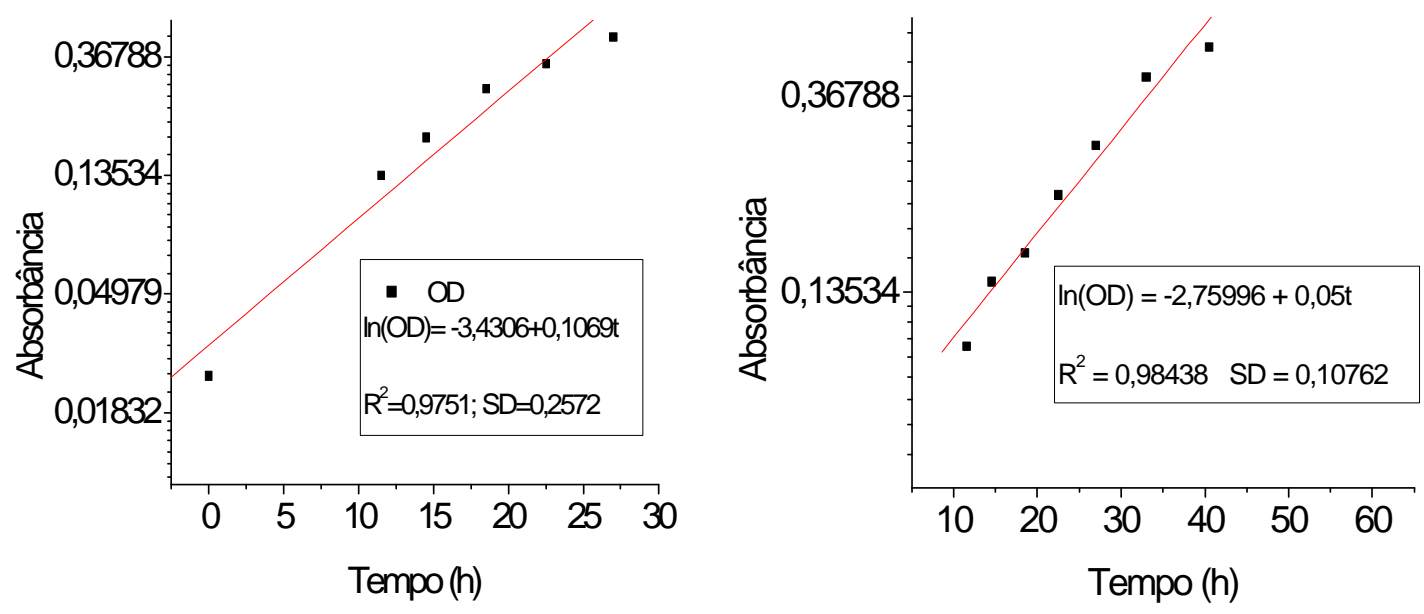

(a)

(b)

Figura 27 - Representação gráfica da absorbância em função do tempo nos reatores controles (etanol e nitrato) com células isoladas em (a) benzeno e (b) etilbenzeno. 


\subsection{Avaliação do consumo de etilbenzeno}

A constatação da variação temporal da concentração de benzeno e etilbenzeno, pode ter sido prejudicada uma vez que retiradas freqüentes de amostras dos reatores foram realizadas para análise de absorbância. Assim, foram realizados novos ensaios em bateladas, com o intuito de avaliar, somente, a variação temporal no consumo de etilbenzeno. Entretanto, os resultados das análises cromatográficas para o etilbenzeno, também, não foram conclusivos. As áreas referentes ao etilbenzeno, e ao padrão interno utilizado nas análises (clorobenzeno) não foram reproduzidas nas triplicatas dos reatores, o que gerou resultados bem diferentes na concentração do etilbenzeno, como demonstrado na Tabela 17.

Tabela 17 - Concentrações de etilbenzeno, obtidas por cromatografia, nas triplicatas de reatores em batelada (R1, R2 e R3).

\begin{tabular}{cccccc}
\hline Reator & Tempo (h) & $\begin{array}{c}\text { Área da } \\
\text { clorobenzeno }\end{array}$ & $\begin{array}{c}\text { Área do } \\
\text { etilbenzeno }\end{array}$ & Fator resposta & $\begin{array}{c}\text { Concentração de } \\
\text { etilbenzeno (mg/L) }\end{array}$ \\
\hline R1 A & 0 & 21,76 & 112,71 & 5,2 & 4,6 \\
R1 B & & 15,1 & 169,26 & 11,2 & 9,3 \\
R2 A & & 27,29 & 273,5 & 10,0 & 8,3 \\
R2 B & & 14,23 & 240,46 & 16,9 & 13,7 \\
R3 A & 21,03 & 281,32 & 13,4 & 10,9 \\
R3 B & 30,02 & 358,28 & 11,9 & 9,8 \\
& & & & & \\
R1 A & 24 & 13,41 & 106,82 & 8,0 & 6,8 \\
R1 B & & 16,47 & 169,21 & 10,3 & 8,5 \\
R2 A & & 14,36 & 163,41 & 11,4 & 9,4 \\
R2 B & 17,69 & 116,14 & 6,6 & 5,7 \\
R3 A & & 18,3 & 97,24 & 5,3 & 4,7 \\
R3 B & & 18,66 & 182,27 & 9,8 & 8,2 \\
& & & & \\
R1 A & 48 & 82,4 & 411,06 & 5,0 & 4,5 \\
R1 B & & 6,7 & 155,04 & 23,1 & 6,4 \\
R2 A & & 23,57 & 167,3 & 7,1 & 8,3 \\
R2 B & 16,2 & 161,54 & 10,0 & 6,0 \\
R3 A & & 19,72 & 137,85 & 7,0 & 6,4 \\
R3 B & 69,23 & 516,35 & 7,5 & \\
\hline
\end{tabular}

As variações nas concentrações de etilbenzeno persistiram, embora diversos testes como mudança do padrão interno, aumento do tempo de aquecimento da amostra, troca de seringa de injeção e troca de seringa para coleta de amostra tenham sido realizados, na tentativa de identificar falhas de procedimento. Uma explicação possível para estas variações foi relacionada, provavelmente, com a solubilidade desse 
composto; ou seja, o etilbenzeno é praticamente insolúvel em água. Embora a solução estoque do etilbenzeno tenha sido preparada em etanol para possibilitar a homogeneidade do composto no meio mineral utilizado nos ensaios, provavelmente, esse composto pode não ter sido completamente solubilizado no meio, o que provocou as variações de concentrações observadas.

Os exames microscópicos das amostras da biomassa microbiana contida nos reatores em batelada alimentados com etilbenzeno revelaram que, após 48 horas de ensaio, as células já se apresentaram com morfologia deformada e debris celulares foram observados, demonstrando a baixa resistência das mesmas ao hidrocarboneto presente no meio.

Variações nas concentrações dos BTEX, por cromatografia, em reatores em batelada, foram também observadas no trabalho realizado por Cattony (2003), com estes hidrocarbonetos. Portanto, com as considerações apresentadas anteriormente, verificouse a necessidade da implementação de outra configuração de reator visando avaliar a remoção do BTEX por culturas desnitrificantes. A utilização de reatores anaeróbios com biomassa imobilizada (RAHLF), para tratamento de águas residuárias que contêm compostos tóxicos, vem sendo amplamente investigada (Damianovic, 1997, Bolaños et.al., 2001; Oliveira al et., 2004), inclusive no tratamento de BTEX (Nardi, 2002; Ribeiro, 2005; Cattony, 2005). Baseado nos relatos de que elevada eficiência na remoção de tóxico vem sendo alcançada nos estudos realizados em reatores com biomassa imobilizada, a capacidade de degradação de BTEX, pelas culturas desnitrificantes isoladas neste estudo, foi avaliada nesta configuração de reator.

\subsection{Imobilização das culturas desnitrificantes no RALHF}

A partir da purificação celular, as culturas foram por várias vezes repicadas, em volumes maiores de meio líquido, para que se obtivesse o aumento da biomassa suficiente para a inoculação nos reatores.

Para diminuir a possível contaminação externa, as células foram imobilizadas nas espumas de poliuretano estéreis, por meio de recirculação, em circuito fechado. Após, retirada da recirculação, células pleomórficas foram observadas (Figura 28). As mudanças observadas foram relacionadas ao fato de que, durante a fase de recirculação, não houve reposição das fontes orgânicas (etanol, etilbenzeno e benzeno) e, devido às 
condições adversas do meio, e a possível toxicidade promovida por benzeno e etilbenzeno, provavelmente, os microrganismos entraram em estado de latência.
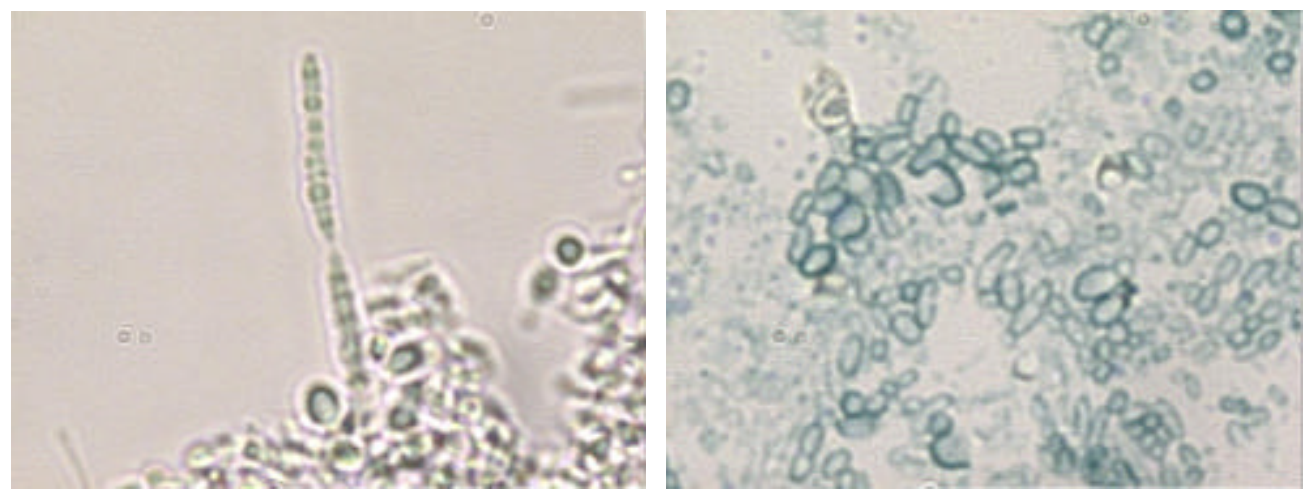

Figura 28 - Pleomorfismo observado nas células dos reatores, após a retirada da recirculação da cultura em microscopia de contraste de fase(1500X).

Com restabelecimento da alimentação contínua dos reatores com substrato fresco, as células voltaram a apresentar morfologia íntegra. No entanto, o monitoramento microscópico, realizado com amostras do biofilme, demonstrou que, diferentemente do observado no crescimento em suspensão, onde cocobacilos eram predominantes, no biofilme, bacilos passaram a predominar (Figura 29). Esta população pode ter se favorecido das condições propiciadas pelo RAHLF. Este reator apresenta configuração cuja imobilização da biomassa ocorre em meio suporte, a espuma de poliuretano. Esse material apresenta como características a porosidade que permite a formação de biofilme denso com elevada atividade metabólica. Estes sistemas apresentam inúmeras vantagens em relação aos reatores operados com biomassa suspensa. Segundo Cohen (2001), um dos fatores que favorece a resistência a compostos tóxicos é o fato de que os polímeros produzidos pelo biofilme exercem uma barreira celular protetora, uma vez que este polímero reduz a concentração do tóxico no interior da célula. 


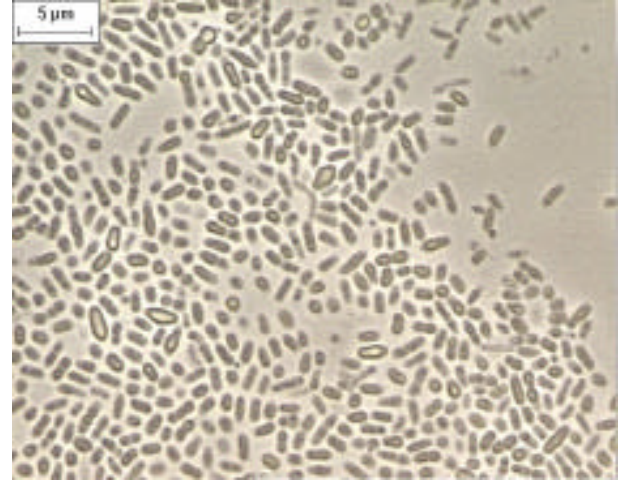

(a)

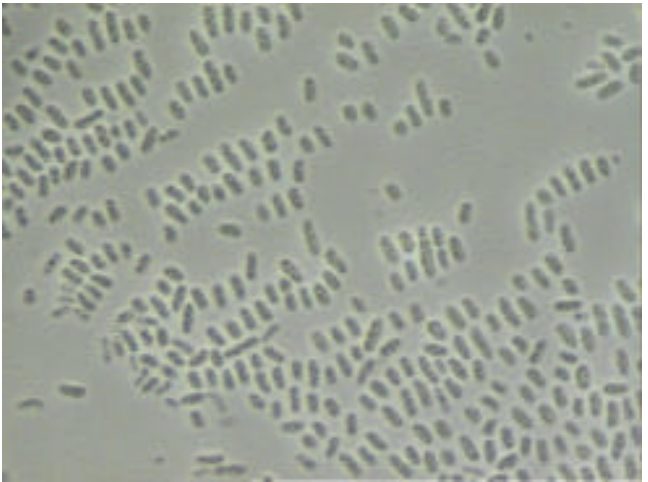

(b)

Figura 29- Microscopia de contraste de fase dos bacilos observados no biofilme dos reatores alimentados com (a) benzeno e (b) etilbenzeno.

\section{9 Monitoramento dos Reatores de Leito Fixo}

\subsubsection{Considerações}

Este item tem como objetivo esclarecer as variações referentes a DQO, observadas durante toda a fase experimental.

Após cerca de 80 dias de operação dos reatores, a concentração da solução etanólica, utilizada no substrato de alimentação, foi alterada, passando-se a utilizar concentração mais elevada de etanol. Esta alteração justificou-se, uma vez que, nas fases seguintes, o reator seria alimentado com concentrações mais elevadas dos hidrocarbonetos. Desta forma, com aumento da concentração do etanol, evitar-se-ia problemas relacionados com baixa solubilidade dos hidrocarbonetos. Devido ao aumento da concentração de etanol no meio, a concentração de nitrato foi, também, corrigida para compensar este aumento.

Outra alteração referente ao etanol deveu-se à adição extra da solução etanólica, em determinadas ocasiões. Compostos de BTEX são altamente voláteis e, embora todos os cuidados tenham sido tomados para que esta volatilização fosse minimizada, muitas vezes, o monitoramento da concentração dos hidrocarbonetos no afluente, indicava concentração inferior à desejada. 
Assim, para que determinada concentração fosse alcançada no afluente, volume conhecido da solução etanólica (etanol + hidrocarboneto), além daquele inicialmente calculado, era adicionado no frasco de alimentação do reator para compensar essa perda que era freqüentemente observada. Todas estas intervenções no substrato de alimentação foram responsáveis pela tendência de aumento das concentrações afluentes, dos parâmetros de monitoramento dos reatores.

As análises realizadas para alcalinidade e ácidos voláteis por titulometria não reproduziram resultados conclusivos e foram desconsideradas nas discussões seguintes. Somente as análises de ácido voláteis realizadas por cromatografia foram consideradas para as discussões relativas aos reatores RAHLF1 e RAHLF2.

\subsubsection{Operação do reator RAHLF1}

O reator RAHLF1 foi operado durante 189 dias, ininterruptamente, substituindose somente os hidrocarbonetos no substrato de alimentação do reator. $\mathrm{O}$ esquema de operação deste reator está representado na Figura 2, no capítulo referente a Material e Métodos. Os valores de todas as medidas realizadas dos parâmetros de monitoramento deste reator estão apresentados no Apêndice H. Os perfis espaciais referentes aos hidrocarbonetos estão disponíveis no Apêndice I.

A Tabela 18 e Figuras 30, 31 e 32 apresentam os resultados dos parâmetros de monitoramento obtidos durante todo o período de operação do reator RAHLF1. 
Tabela 18 - Valores dos parâmetros de monitoramento do RAHLF1, obtidos durante o período de operação.

\begin{tabular}{|c|c|c|c|c|c|}
\hline \multirow{2}{*}{ Parâmetros } & \multicolumn{2}{|c|}{ Afluente } & \multicolumn{2}{|c|}{ Efluente } & \multirow{2}{*}{$\begin{array}{c}\text { Eficiência } \\
\text { Média de } \\
\text { Remoção } \\
(\%)\end{array}$} \\
\hline & Média & Variação & Média & Variação & \\
\hline \multicolumn{6}{|c|}{ Alimentação com benzeno } \\
\hline $\mathrm{DQO}_{\text {Bruta. }}(\mathrm{mg} / \mathrm{L})$ & 969,9 & $869,0-1258,1$ & 116,7 & $59,6-259,1$ & 88,0 \\
\hline $\mathrm{DQO}_{\text {Filtrada }}(\mathrm{mg} / \mathrm{L})$ & 944,2 & $823,5-1213,8$ & 84,1 & $31,4-162,5$ & 91,1 \\
\hline $\mathrm{N}-\mathrm{NO}_{3}{ }^{-}(\mathrm{mg} / \mathrm{L})$ & 398,6 & $348,5-581,0$ & $48, .3$ & $0,85-121,6$ & 87,9 \\
\hline $\mathrm{PH}$ & 7,2 & $7,0-7,5$ & 8,9 & $7,3-9,6$ & - \\
\hline $\mathrm{SSV}(\mathrm{mg} / \mathrm{L})$ & 14,0 & $10,0-47,0$ & 39,4 & $22,0-58,0$ & - \\
\hline \multicolumn{6}{|c|}{ Alimentação com tolueno } \\
\hline $\mathrm{DQO}_{\text {Bruta. }}(\mathrm{mg} / \mathrm{L})$ & 1171,0 & $914,8-1316,5$ & 35,5 & $10,3-48,1$ & 97,0 \\
\hline $\mathrm{DQO}_{\text {Filtrada }}(\mathrm{mg} / \mathrm{L})$ & 1121,4 & $838,9-1264,1$ & 30,0 & $0,0-72,9$ & 97,3 \\
\hline $\mathrm{N}-\mathrm{NO}_{3}{ }^{-}(\mathrm{mg} / \mathrm{L})$ & 547,6 & $502,2-622,5$ & 52,0 & $0,0-127,0$ & 90,5 \\
\hline $\mathrm{pH}$ & 7,2 & $7,0-7,5$ & 9,1 & $8,6-9,7$ & - \\
\hline $\mathrm{SSV}(\mathrm{mg} / \mathrm{L})$ & 45,2 & $21,0-62,0$ & 49,7 & $18,0-65,0$ & - \\
\hline \multicolumn{6}{|c|}{ Alimentação com $m$-xileno } \\
\hline $\mathrm{DQO}_{\text {Bruta. }}(\mathrm{mg} / \mathrm{L})$ & 1287,4 & $1252,4-1322,3$ & 143,7 & $65,6-300$ & 88,8 \\
\hline $\mathrm{DQO}_{\text {Filtrada }}(\mathrm{mg} / \mathrm{L})$ & 1262,1 & $1252,4-1269,9$ & 120,9 & $46,7-262,1$ & 90,4 \\
\hline $\mathrm{N}-\mathrm{NO}_{3}{ }^{-}(\mathrm{mg} / \mathrm{L})$ & 482,2 & $439,0-527,8$ & 5,1 & $40-6,2$ & 98,9 \\
\hline $\mathrm{pH}$ & 7,2 & $7,18-7,23$ & 8,9 & $8,9-9,0$ & - \\
\hline $\mathrm{SSV}(\mathrm{mg} / \mathrm{L})$ & 47,7 & $40,0-58,0$ & 55,0 & $47,0-68,0$ & - \\
\hline \multicolumn{6}{|c|}{ Alimentação etilbenzeno } \\
\hline $\mathrm{DQO}_{\text {Bruta. }}(\mathrm{mg} / \mathrm{L})$ & 1497,1 & $1438,8-1526,2$ & 285,4 & $272,3-305,8$ & 80,9 \\
\hline $\mathrm{DQO}_{\text {Filtrada }}(\mathrm{mg} / \mathrm{L})$ & 1500,9 & $1409,7-1561,1$ & 277.7 & $228,7-330,6$ & 81,5 \\
\hline $\mathrm{N}-\mathrm{NO}_{3}{ }^{-}(\mathrm{mg} / \mathrm{L})$ & 514,8 & $497,8-538,9$ & 4.1 & $2,8-5,1$ & 99,2 \\
\hline $\mathrm{pH}$ & 7,4 & $7,4-7,5$ & 8.9 & $8,9-9,0$ & - \\
\hline $\mathrm{SSV}(\mathrm{mg} / \mathrm{L})$ & 51,0 & $21,0-70,0$ & 60.7 & $27,0-78,0$ & - \\
\hline \multicolumn{6}{|c|}{ Alimentação com BTEX } \\
\hline $\mathrm{DQO}_{\text {Bruta. }}(\mathrm{mg} / \mathrm{L})$ & 1992,3 & $1957,1-2027,5$ & 532,5 & $461,6-603,5$ & 73,3 \\
\hline $\mathrm{DQO}_{\text {Filtrada }}(\mathrm{mg} / \mathrm{L})$ & 1837,7 & $1782,4-1893,1$ & 500,9 & $419,4-582,5$ & 72,7 \\
\hline $\mathrm{N}-\mathrm{NO}_{3}{ }^{-}(\mathrm{mg} / \mathrm{L})$ & 446,5 & $417,5-475,5$ & 4,0 & $3,1-4,9$ & 99,1 \\
\hline $\mathrm{pH}$ & 7,7 & - & 9,0 & - & - \\
\hline $\mathrm{SSV}(\mathrm{mg} / \mathrm{L})$ & 34,0 & $33,0-35,0$ & 41,5 & $36,0-47,0$ & - \\
\hline
\end{tabular}

As primeiras análises dos parâmetros de monitoramento já mostravam a estabilidade do reator, indicando a rápida adaptação do biofilme (Figuras 30, 31 e 32). 
O reator apresentou boa estabilidade durante os primeiros 80 dias (alimentação com benzeno), com elevadas eficiências de remoção da matéria orgânica (avaliada na forma de DQO), (Figura 30 e Tabela 18).

Durante a fase de alimentação com benzeno e tolueno, mesmo com o aumento da DQO afluente, devido à alteração da concentração de etanol no substrato, o reator retomou sua estabilidade, apresentando eficiência de remoção da matéria orgânica superior a 90\%. No entanto, o reator mostrou uma tendência à instabilidade, durante a fase de alimentação do mesmo com m-xileno, etilbenzeno e BTEX (Figura 30). Nestas condições, foi observada diminuição da eficiência de remoção de DQO (Tabela 18). Esta instabilidade foi associada, principalmente, à diminuição do tempo destinado à alimentação com estes hidrocarbonetos (15 dias com cada composto), dificultando a adaptação do biofilme às novas condições, e conseqüentemente afetando o equilíbrio dinâmico do reator.

Os valores obtidos para a DQO bruta apresentaram-se muito semelhantes àqueles obtidos para a DQO filtrada, mostrando o reduzido desprendimento celular no efluente do reator (Figura 30).

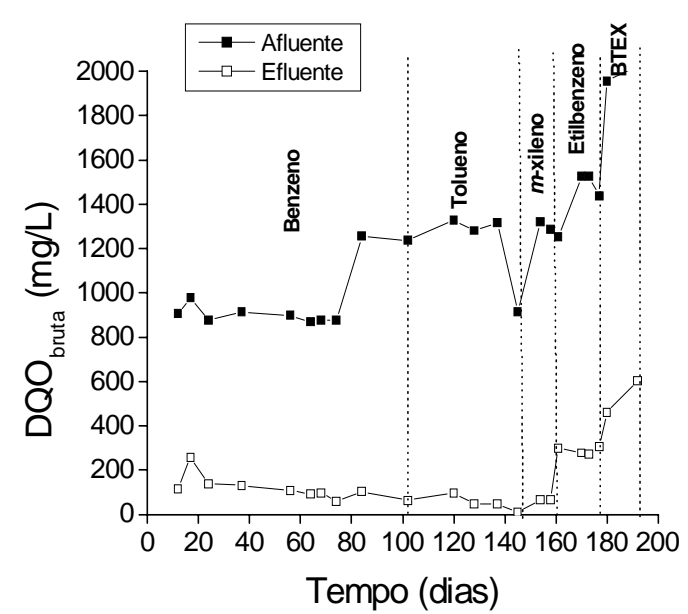

(a)

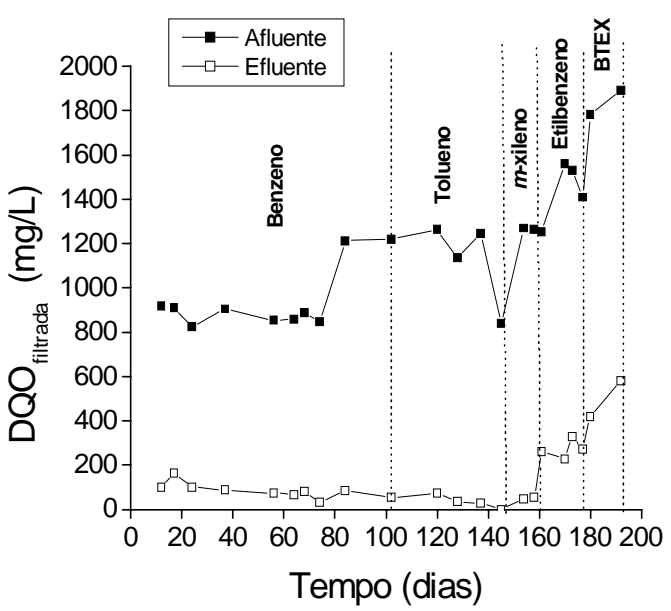

(b)

Figura 30 - Variação temporal da concentração de $\mathrm{DQO}_{\text {Bruta }}$ (a) e DQO Filtrada $($ b) durante operação do reator RAHLF1.

Para compensar o aumento da concentração de etanol no substrato, a concentração de nitrato foi, também, corrigida. Este aumento na concentração de nitrato $\left(\mathrm{N}^{-} \mathrm{NO}_{3}{ }^{-}\right)$pode ser observado após aproximadamente 80 dias de operação do reator (Figura 31 a). $\mathrm{O}$ aumento da concentração de nitrato $\left(\mathrm{N}_{-} \mathrm{NO}_{3}{ }^{-}\right)$, foi acompanhado por melhores eficiências de remoção desta substância no decorrer do período de operação 
do reator (Tabela 18). A maior concentração de nitrato efluente $\left(127,0 \mathrm{mg} / \mathrm{L} \mathrm{N}^{-N_{3}}{ }^{-}\right)$ observada (aproximadamente, 145 dias de operação) deveu-se ao excesso do aceptor final de elétrons em relação à quantidade de carbono, devido a um erro durante o preparo da solução etanólica utilizada no substrato.

A formação de nitrito $\left(\mathrm{N}-\mathrm{NO}_{2}{ }^{-}\right)$foi verificada durante todo o período de operação, indicando a realização do metabolismo desnitrificante pelas células do biofilme (Figura $31 \mathrm{~b}$ ).
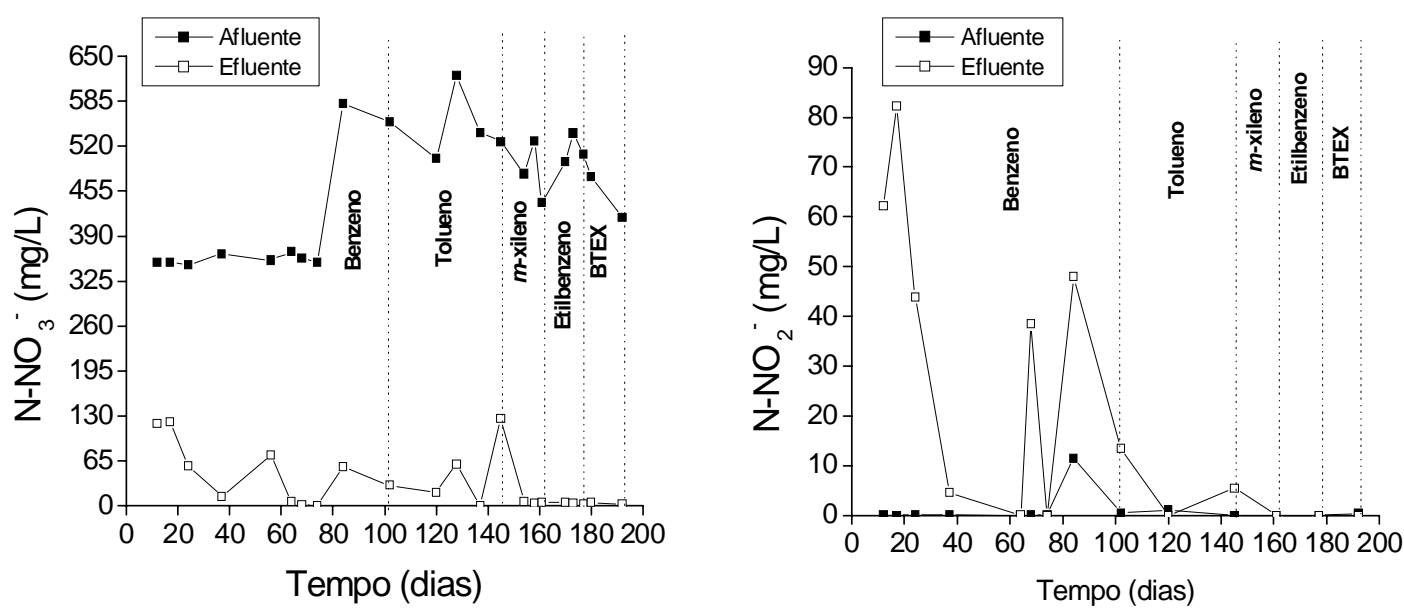

(a)

Figura 31 - Variação temporal da concentração de nitrato $\mathrm{N}^{-\mathrm{NO}_{3}}{ }^{-}$(a) e nitrito $\mathrm{N}^{-} \mathrm{NO}_{2}^{-}$(b) durante operação do reator RAHLF1.

As flutuações observadas na alcalinidade efluente foram acompanhadas pela alcalinização do pH efluente que foi, em média, de 8,9 (Figura 32 a).

Após, cerca de 80 dias de operação foi observado comportamento diferenciado em relação aos sólidos suspensos voláteis (que avalia a presença de biomassa) (Figura 32 b). Percebeu-se que após este período, a concentração afluente de SSV foi substancialmente superior ao observado no início da operação do reator. Este resultado foi relacionado com a mudança do local de coleta para esta análise. Inicialmente, esta amostragem era realizada diretamente no frasco de alimentação. No entanto, as análises referentes às concentrações afluentes dos hidrocarbonetos ficavam superestimadas, quando avaliadas a partir deste local, uma vez que, a perda destes compostos era observada no percurso entre o frasco de alimentação e a entrada do reator. Desta forma, optou-se por fazer as amostragens referentes ao afluente, desconectando-se a mangueira existente entre o frasco de alimentação e a entrada do reator. Como neste local o crescimento da biomassa era intenso, a presença de células era freqüentemente 
detectada nas amostragens afluentes, como observado para as análises de SSV. Em relação à instabilidade observada para o SSV efluente, observou-se que esta instabilidade ocorreu principalmente quando o reator passou a ser operado por períodos cada vez mais curtos, o que pode ter dificultado a adaptação celular às novas condições, ocasionando maior desprendimento de células.

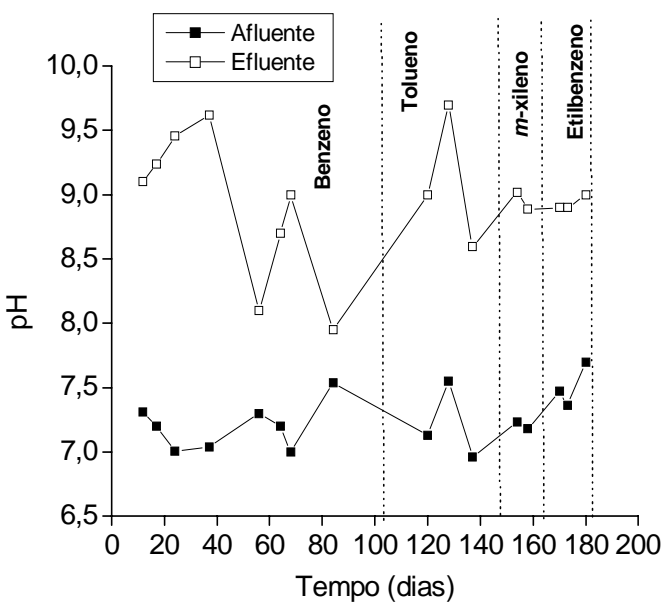

(a)

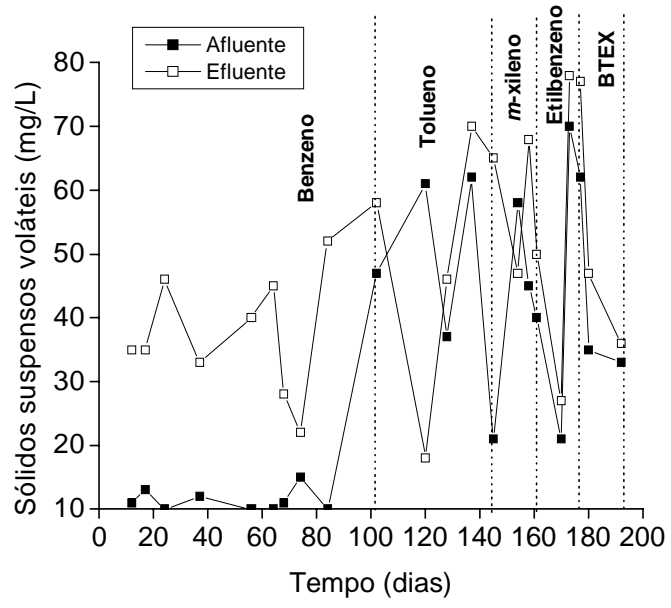

(b)

Figura 32 - Variação temporal do pH (a) e sólidos suspensos voláteis (b), durante operação do reator RAHLF1.

A Tabela 19 apresenta as concentrações afluentes e efluentes dos hidrocarbonetos, $\mathrm{DQO}_{\mathrm{f}}$, nitrato $\left(\mathrm{N}^{-\mathrm{NO}_{3}}{ }^{-}\right)$, nitrito $\left(\mathrm{N}-\mathrm{NO}_{2}{ }^{-}\right)$e ácido acético, obtidas nos perfis espaciais referentes as alimentações com cada hidrocarboneto. 
Tabela 19 - Concentrações afluentes e efluentes dos parâmetros avaliados durante os perfis realizados no reator RAHLF1, em diferentes condições de alimentação.

\begin{tabular}{|c|c|c|c|c|}
\hline \multirow[t]{2}{*}{ Parâmetro } & \multirow{2}{*}{$\begin{array}{l}\text { Tempo de } \\
\text { operação } \\
\text { (dias) }\end{array}$} & \multicolumn{2}{|c|}{$\begin{array}{c}\text { Concentração } \\
(\mathrm{mg} / \mathrm{L})\end{array}$} & \multirow{2}{*}{$\begin{array}{c}\text { Eficiência } \\
\text { média de } \\
\text { Remoção } \\
(\%)\end{array}$} \\
\hline & & Afluente & Efluente & \\
\hline Benzeno & 24 & 13,8 & 0,9 & 93,5 \\
\hline DQO $_{\text {FILTRADA }}(\mathrm{mg} / \mathrm{L})$ & & 823,5 & 100,7 & 87,9 \\
\hline $\mathrm{N}-\mathrm{NO}_{3}{ }^{-}(\mathrm{mg} / \mathrm{L})$ & & 348,5 & 57,9 & 83,4 \\
\hline $\mathrm{N}-\mathrm{NO}_{2}^{-}(\mathrm{mg} / \mathrm{L})$ & & 0,00 & 43,9 & - \\
\hline Ácido acético (mg/L) & & 0,00 & 0,6 & - \\
\hline Benzeno & 51 & 15,4 & 0,1 & 99,3 \\
\hline DQO $_{\text {FILTRADA }}(\mathrm{mg} / \mathrm{L})$ & & 849,3 & 31,4 & 96,3 \\
\hline $\mathrm{N}-\mathrm{NO}_{3}^{-}(\mathrm{mg} / \mathrm{L})$ & & 351,8 & 0,8 & 99,8 \\
\hline $\mathrm{N}-\mathrm{NO}_{2}^{-}(\mathrm{mg} / \mathrm{L})$ & & 0,00 & 0,00 & - \\
\hline Ácido acético (mg/L) & & 0,00 & 0,00 & - \\
\hline Benzeno & 27 & 26,5 & 0,4 & 98,5 \\
\hline DQO $_{\text {FILTRADA }}(\mathrm{mg} / \mathrm{L})$ & & 1220,2 & 53,6 & 95,6 \\
\hline $\mathrm{N}-\mathrm{NO}_{3}^{-}(\mathrm{mg} / \mathrm{L})$ & & 554,6 & 30,2 & 94,5 \\
\hline $\mathrm{N}-\mathrm{NO}_{2}^{-}(\mathrm{mg} / \mathrm{L})$ & & 0,5 & 13,5 & - \\
\hline Ácido acético (mg/L) & & 0,00 & 0,00 & 0,00 \\
\hline Tolueno & 42 & 30,8 & 0,1 & 99,6 \\
\hline DQO $_{\text {FILTRADA }}(\mathrm{mg} / \mathrm{L})$ & & 839,9 & 0,00 & 100,0 \\
\hline $\mathrm{N}-\mathrm{NO}_{3}{ }^{-}(\mathrm{mg} / \mathrm{L})$ & & 526,7 & 127,0 & 75,9 \\
\hline $\mathrm{N}-\mathrm{NO}_{2}^{-}(\mathrm{mg} / \mathrm{L})$ & & 0,00 & 5,5 & - \\
\hline Ácido acético (mg/L) & & 0,00 & 5,1 & - \\
\hline$m$-xileno & 15 & 32,1 & 0,1 & 99,7 \\
\hline DQO $_{\text {FILTRADA }}(\mathrm{mg} / \mathrm{L})$ & & 1252,4 & 262,1 & 79,1 \\
\hline $\mathrm{N}-\mathrm{NO}_{3}^{-}(\mathrm{mg} / \mathrm{L})$ & & 439,0 & 5,0 & 98,9 \\
\hline $\mathrm{N}-\mathrm{NO}_{2}^{-}(\mathrm{mg} / \mathrm{L})$ & & 0,00 & 0,00 & - \\
\hline Ácido acético (mg/L) & & 18,4 & 214,4 & - \\
\hline Etilbenzeno & 15 & 33,3 & 0,4 & 98,8 \\
\hline DQO $_{\text {FILTRADA }}(\mathrm{mg} / \mathrm{L})$ & & 1409,7 & 273,8 & 80,6 \\
\hline $\mathrm{N}-\mathrm{NO}_{3}{ }^{-}(\mathrm{mg} / \mathrm{L})$ & & 507,8 & 2,8 & 99,5 \\
\hline $\mathrm{N}-\mathrm{NO}_{2}^{-}(\mathrm{mg} / \mathrm{L})$ & & 0,00 & 0,00 & - \\
\hline Ácido acético (mg/L) & & 0 & 261,9 & - \\
\hline BTEX & 15 & 26,5 & $0,3^{*}$ & 98,8 \\
\hline DQO $_{\text {FILTRADA }}(\mathrm{mg} / \mathrm{L})$ & & 1893,1 & 582,5 & 69,2 \\
\hline $\mathrm{N}-\mathrm{NO}_{3}^{-}(\mathrm{mg} / \mathrm{L})$ & & 417,5 & 3,1 & 99,3 \\
\hline $\mathrm{N}-\mathrm{NO}_{2}^{-}(\mathrm{mg} / \mathrm{L})$ & & 0,35 & 0,00 & - \\
\hline Ácido acético (mg/L) & & 20,9 & 571,5 & - \\
\hline
\end{tabular}

*concentração referente ao benzeno $=0,26 \mathrm{mg} / \mathrm{L} ;$ tolueno $=0,05 \mathrm{mg} / \mathrm{L}$; etilbenzeno $=0,01$ $\mathrm{mg} / \mathrm{L} ; o$-xileno $=0,00 \mathrm{mg} / \mathrm{L} ; m, p$-xilenos $=0,00 \mathrm{mg} / \mathrm{L}$. 
Nos perfis espaciais, observou-se que a matéria orgânica $\left(\mathrm{DQO}_{\mathrm{f}}\right)$ era removida, principalmente, no primeiro ponto de amostragem ( $\mathrm{L} / \mathrm{D}=4)$ (Figura 33).

O consumo da matéria orgânica levou a formação de ácido acético em todas as condições de alimentação do reator. No entanto, a produção e o consumo de ácido acético só foram verificados durante a fase de alimentação do reator com benzeno e tolueno (Figura 33).
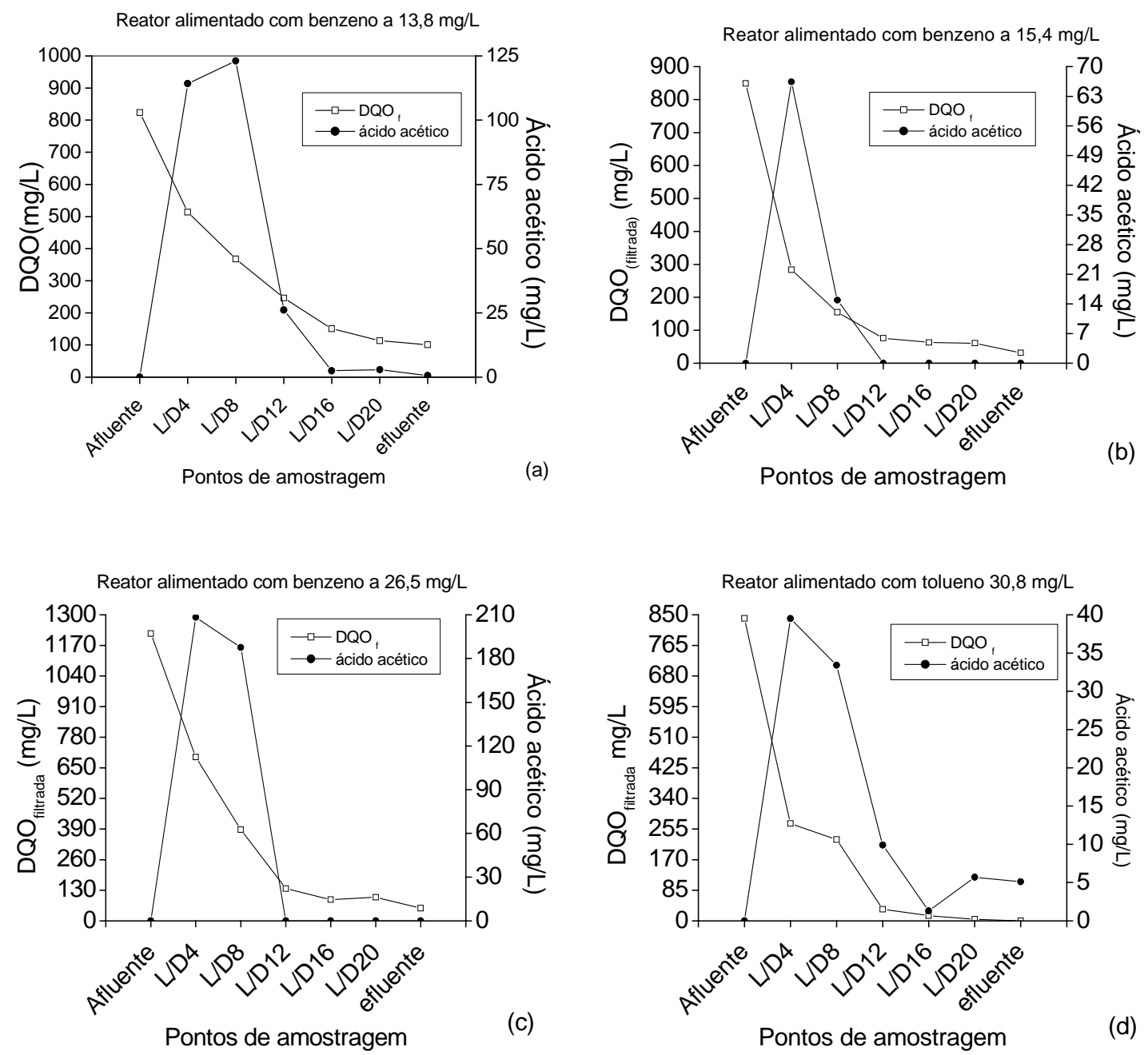

Figura 33 - Variação espacial da concentração da matéria orgânica (DQO) e ácido acético no reator RAHLF1 alimentado com benzeno (a, b, c) e tolueno (d).

Nas alimentações com m-xileno, etilbenzeno e BTEX, elevadas concentrações deste ácido foram detectadas no efluente (Figura 34). 

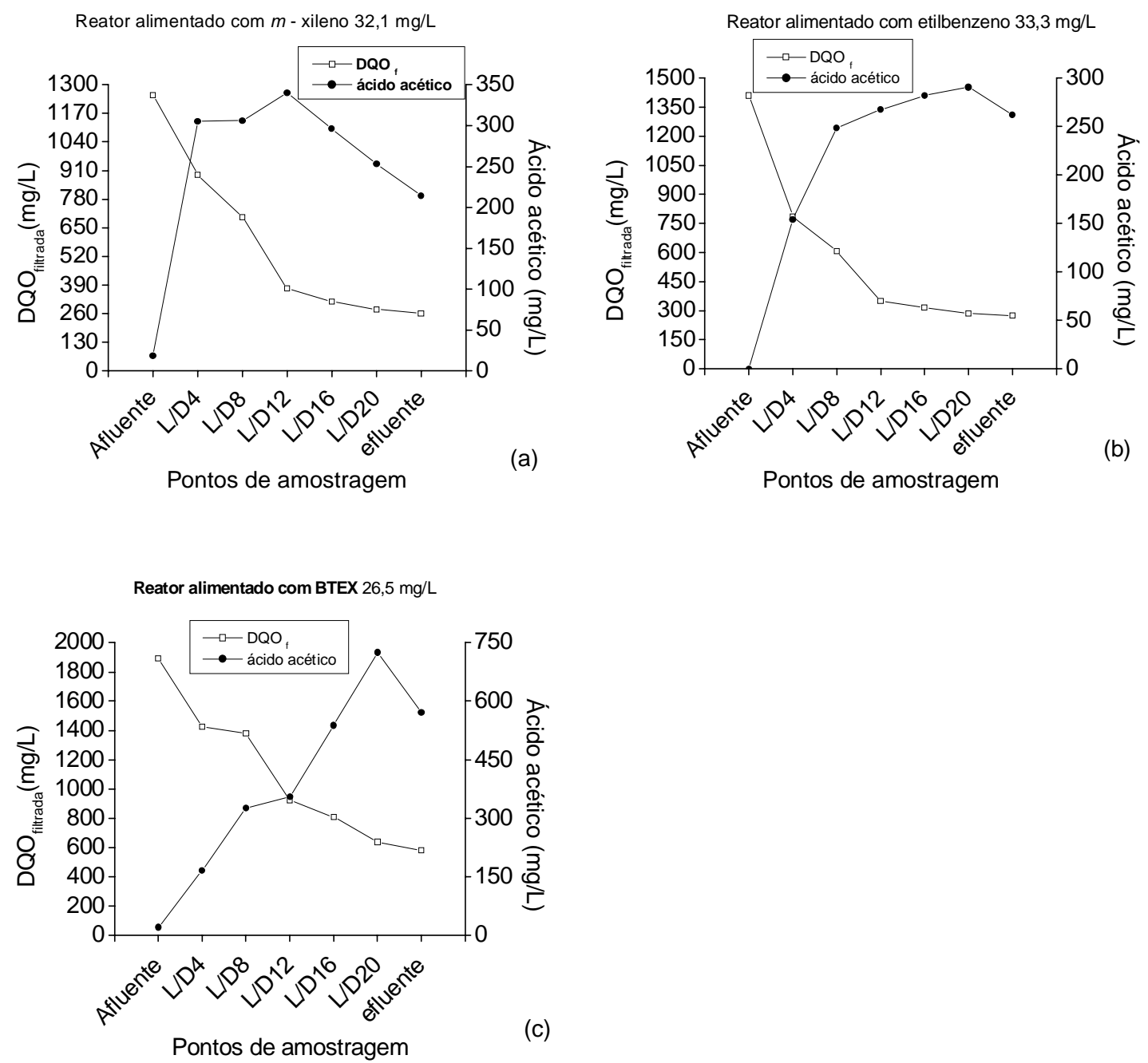

Figura 34 - Variação espacial da concentração da matéria orgânica $\left(\mathrm{DQO}_{\mathrm{f}}\right)$ e ácido acético no reator RAHLF1 alimentado com (a) m-xileno, (b) etilbenzeno e (c) BTEX.

As análises dos resultados obtidos dos perfis referentes às alimentações com $m$ xileno, etilbenzeno e BTEX demonstraram que, nestas condições, também foram detectadas baixas concentrações de nitrato $\left(\mathrm{N}^{-\mathrm{NO}_{3}}{ }^{-}\right)$, no quinto ponto de amostragem do reator $(\mathrm{L} / \mathrm{D}=20)$, onde as concentrações desta substância foram de 6,7 mg/L, 4,4 mg/L, e 3,8 mg/L, para as alimentações com $m$-xileno, etilbenzeno e BTEX, respectivamente (Figura 35 e, f, g). Assim, o acúmulo de ácido acético pode estar associado ao esgotamento do aceptor final de elétrons (nitrato). É importante ressaltar que, o tempo destinado para a operação do reator, com cada um destes hidrocarbonetos, foi de cerca de 15 dias. Portanto, é possível que o tempo de operação, para estas condições, tenha sido insuficiente para que as populações responsáveis pelo consumo de ácido acético se 
adaptassem ás novas condições não sendo capazes de consumir ácido acético presente nos últimos trechos do reator.
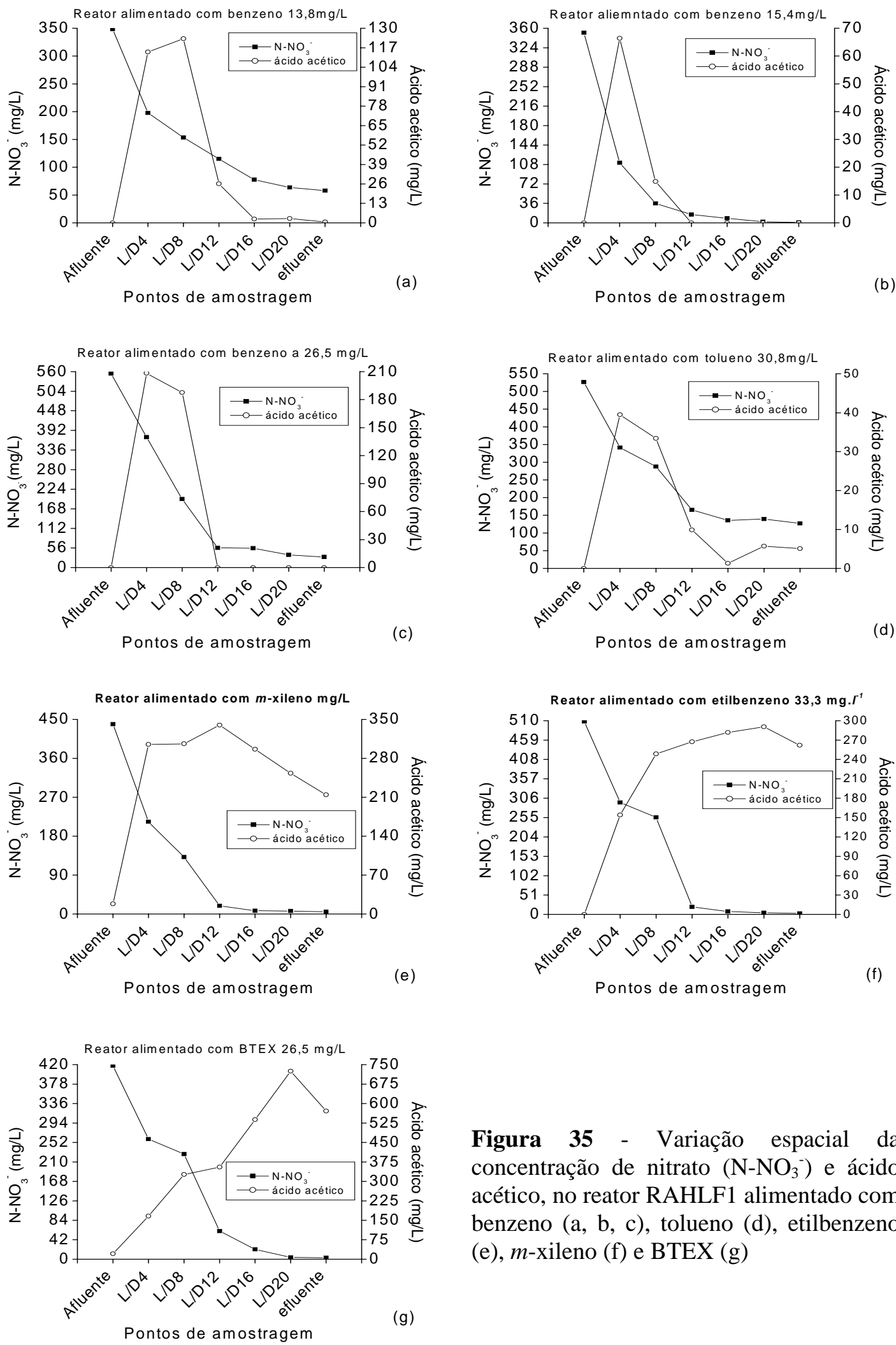

Figura 35 - Variação espacial da concentração de nitrato $\left(\mathrm{N}^{-} \mathrm{NO}_{3}^{-}\right)$e ácido acético, no reator RAHLF1 alimentado com benzeno $(\mathrm{a}, \mathrm{b}, \mathrm{c})$, tolueno $(\mathrm{d})$, etilbenzeno (e), $m$-xileno (f) e BTEX (g) 
Devido à presença de ácido acético no efluente, foram obtidas menores eficiências de remoção da $\mathrm{DQO}_{\mathrm{f}}$, nas alimentações com $m$-xileno $(79,1 \%)$, etilbenzeno $(80,6 \%)$ e BTEX $(69,2 \%)$, quando comparada às alimentações com benzeno $(87,9 \%$, $96,3 \%$ e $95,6 \%)$ e tolueno (100\%). (Tabela 19$)$.

Comportamento semelhante foi também observado por Ribeiro (2005) e Nardi (2002) operando RALHF desnitrificante, tratando BTEX. Nesses trabalhos, os autores verificaram o acúmulo de ácido acético após a sobrecarga orgânica, o que promoveu o desbalanceamento dos sistemas.

No presente estudo, durante a alimentação com $m$-xileno e BTEX, foi detectado ácido acético no afluente do reator (Tabela 19). Considerando-se que as amostras retiradas para análises do afluente eram coletadas na mangueira de alimentação do reator, a presença de ácido acético no afluente decorreu, provavelmente, da atividade do biofilme indevidamente formado na mangueira, nesta condição. Embora estas mangueiras fossem esterilizadas freqüentemente, a formação do biofilme neste local era constantemente observada.

A Figura 36 apresenta os perfis de concentração de nitrato $\left(\mathrm{N}-\mathrm{NO}_{3}{ }^{-}\right)$e nitrito $(\mathrm{N}-$ $\left.\mathrm{NO}_{2}{ }^{-}\right)$ao longo do reator RAHLF1. As remoções mais acentuadas de nitrato $\left(\mathrm{N}_{-} \mathrm{NO}_{3}{ }^{-}\right)$ ocorreram no primeiro trecho do reator, coincidindo com a maior concentração da biomassa. No entanto, o nitrato esteve disponível ao longo de todo o reator, permitindo que o metabolismo desnitrificante fosse realizado por toda a biomassa presente no sistema. Estes resultados demonstram que a cultura desnitrificante presente no biofilme apresentou-se altamente eficiente para o consumo da matéria orgânica no RAHLF. De forma diferente, no estudo de Ribeiro (2005), o autor observou que, ao final do período de operação com o RAHLF desnitrificante, tratando gasolina, a remoção da matéria orgânica ocorria apenas no primeiro trecho do reator, produzindo elevada quantidade de ácido acético que, por sua vez, era consumido em condições metanogênicas, no restante do reator. Assim o RAHLF estudado por Ribeiro (2005), foi caracterizado como um sistema misto. 

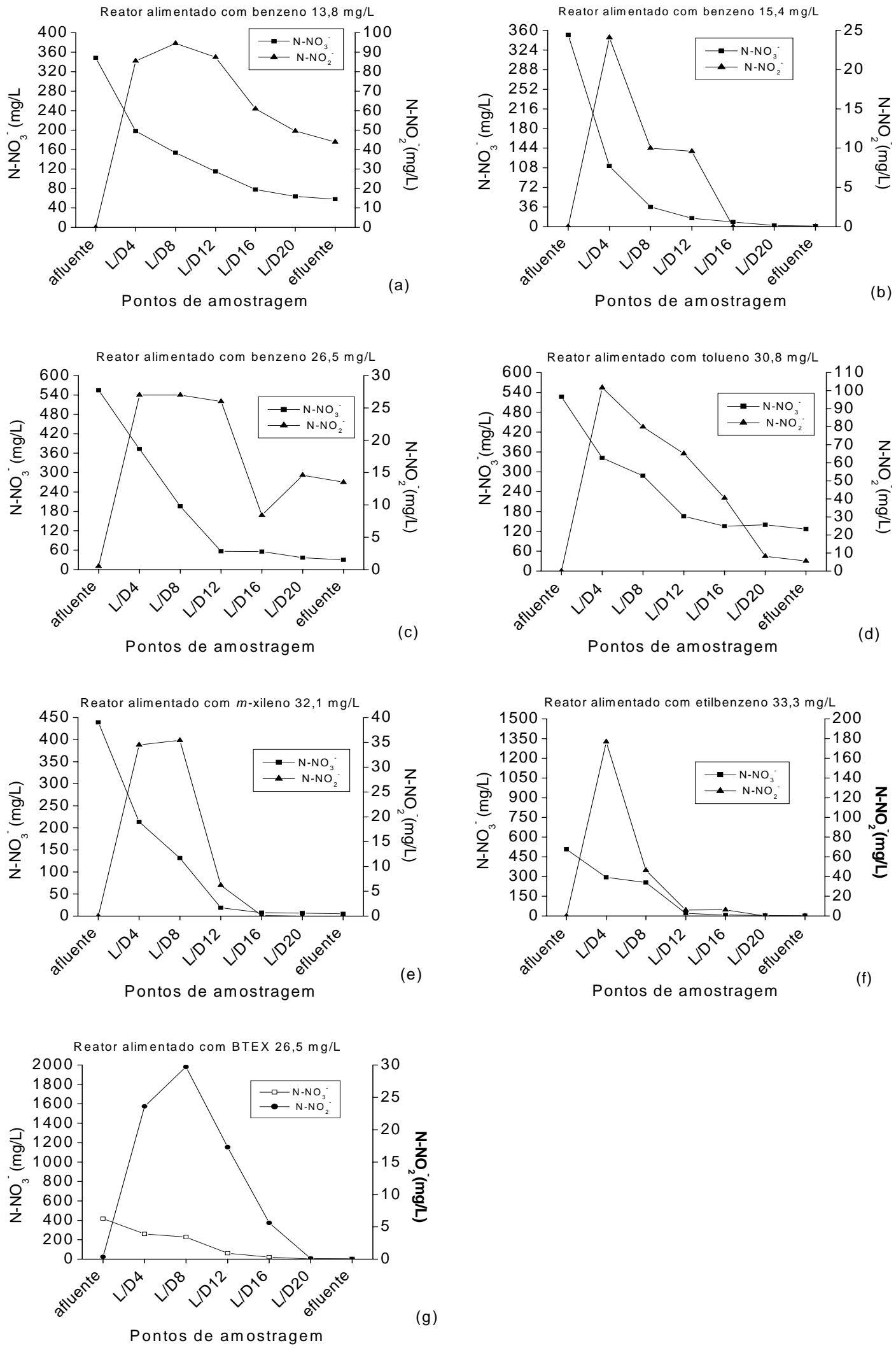

Figura 36 - Variação espacial da concentração de nitrato $\left(\mathrm{N}^{-\mathrm{NO}_{3}}{ }^{-}\right)$e nitrito $\left(\mathrm{N}^{-\mathrm{NO}_{2}}{ }^{-}\right)$no reator RAHLF1 alimentado com (a, b, c) benzeno em diferentes concentrações, (d) tolueno, (e) $m$ xileno, (f) etilbenzeno e (g) BTEX 
A dinâmica esperada no metabolismo de desnitrificação completa, onde o nitrato $\left(\mathrm{N}^{-} \mathrm{NO}_{3}{ }^{-}\right)$foi totalmente consumido, e o nitrito $\left(\mathrm{N}^{-\mathrm{NO}_{2}}{ }^{-}\right)$foi produzido e consumido ao longo do reator, pôde ser constatada durante os perfis referentes às alimentações com benzeno, $m$-xileno, etilbenzeno, e BTEX (Figura 36 b, e, f, g). Residuais de nitrito de 43,9 mg/L, 13,5 mg/L, e 5,1mg/L foram detectados no efluente das alimentações com benzeno e tolueno (Figura 36 a, c, d).

No Brasil, a resolução 357 de 17 de Março de 2005 do CONAMA (Conselho Nacional do meio ambiente) não estabelece diretamente as concentrações de nitrato e nitrito que podem estar presentes nos efluentes de sistemas de tratamento de esgotos. Apenas a concentração de amônia encontra-se limitada em 20 mg-N/L. No entanto, a limitação das concentrações de nitrato e nitrito segue a determinação baseada na classificação das águas doces, pertencentes às classes 1, 2 e 3, do Território Nacional, sendo que as concentrações máximas admitidas destas substâncias são iguais a $10 \mathrm{mg}$ $\mathrm{N}-\mathrm{NO}_{3} / \mathrm{L}$ e 1,0 mg N-NO $2 / \mathrm{L}$, respectivamente.

Segundo os estudos de Kuhn et al. (1988) e Schocher et al. (1991), o nitrito formado durante a desnitrificação pode ser tóxico para a biomassa. Élmen et al. (1997) obtiveram constantes de inibição pelo nitrato de 582,8 $\mathrm{mg} / \mathrm{L}$, e pelo nitrito de 552,0 $\mathrm{mg} / \mathrm{L}$, respectivamente. No presente estudo, a maior concentração de nitrato $\left(\mathrm{N}^{-\mathrm{NO}_{3}}{ }^{-}\right)$e nitrito $\left(\mathrm{N}_{-} \mathrm{NO}_{2}{ }^{-}\right)$detectada, durante todo o período experimental com o reator RAHLF1, foi de 554,6 mg/L e 176,7 mg/L, respectivamente. No entanto, nenhuma conclusão pôde ser feita a respeito da inibição destas substâncias para a biomassa, uma vez que estudos sobre o tema não foram realizados neste trabalho.

A Figura 37 apresenta a variação das concentrações dos hidrocarbonetos obtidas durante os perfis.

O reator apresentou altas eficiências de remoção dos hidrocarbonetos em todas as condições de alimentação as quais o mesmo foi submetido (Tabela 19). A menor eficiência de remoção foi de $93,5 \%$, obtida durante o perfil referente à alimentação do reator com benzeno $13,8 \mathrm{mg} / \mathrm{L}$.

Estudos realizados com RAHLF tratando BTEX, sob condições desnitrificantes, demonstram elevada eficiência deste sistema no tratamento destes compostos. No estudo de Ribeiro (2005), as eficiências para remoção de benzeno (4,9mg/L), tolueno (7,2 mg/L), m-xileno (3,7 mg/L) e BTEX $(15,9 \mathrm{mg} / \mathrm{L})$, após o reator ter atingido o estado estacionário, foram de 96,3\%, 95,7\%, 96,3\% e 96,1\%, respectivamente. Elevadas eficiências de remoção para BTEX foram, também, observadas no trabalho de Nardi 
(2002), durante a fase de alimentação do reator com solução etanólica com BTEX (5,0 $\mathrm{mg} / \mathrm{L}$ de cada composto, aproximadamente). Neste último estudo, as concentrações de benzeno, tolueno e etilbenzeno no efluente foram menores que $0,1 \mathrm{mg} / \mathrm{L}$, e isômeros de xileno não foram detectados durante todo o período do experimento.

A remoção dos hidrocarbonetos ocorreu, principalmente, no primeiro trecho do reator. No entanto, especialmente, durante o perfil do benzeno $26,5 \mathrm{mg} / \mathrm{L}$, observou-se que a remoção foi, ligeiramente, mais distribuída ao longo do reator (Figura 37 a). Este comportamento sugere ligeira dificuldade da biomassa em promover a remoção do benzeno em elevadas concentrações.
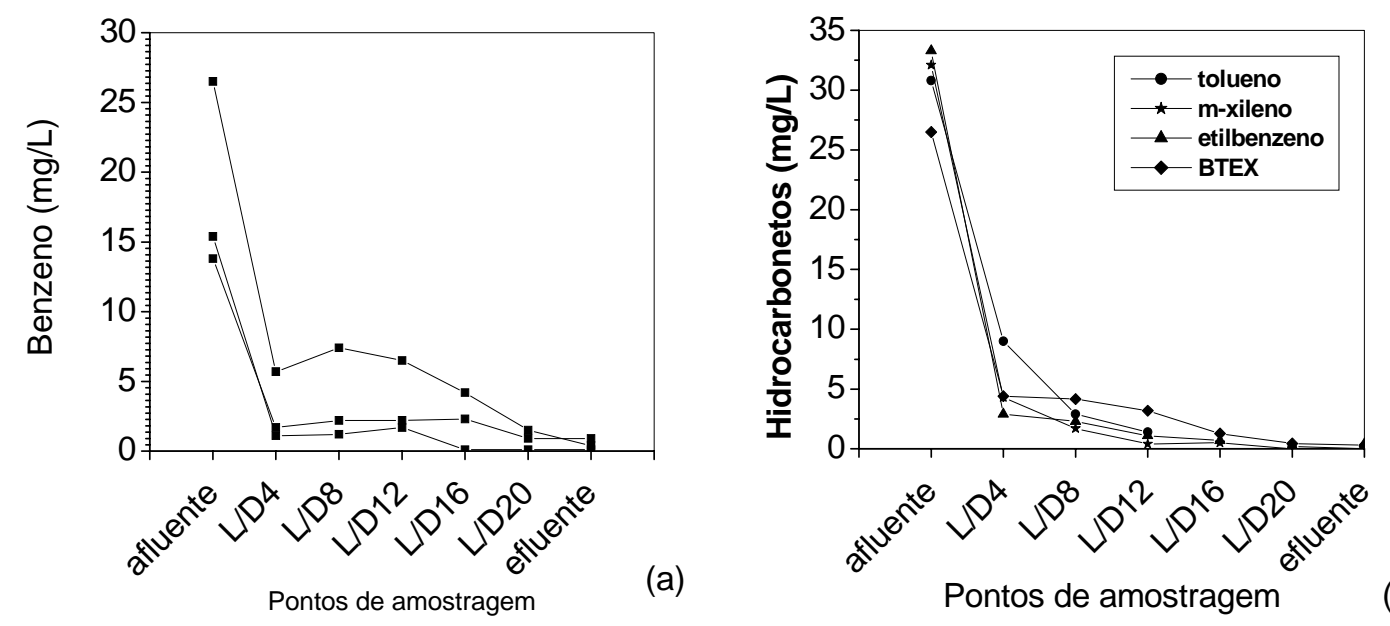

Pontos de amostragem

(b)

Figura 37 - Variação espacial da concentração de (a) benzeno e (b) tolueno, m-xileno, etilbenzeno e BTEX, no reator RAHLF1.

No Brasil, em relação às concentrações máximas de hidrocarbonetos aromáticos que os despejos industriais podem conter, o CONAMA (Resolução n²0 de 18 de junho de 1986) estabelece somente alguns teores máximos para alguns compostos orgânicos, entre eles o benzeno $\left(10,0 \mu \mathrm{g} . \mathrm{l}^{-1}\right)$. A Portaria $\mathrm{n}^{\circ} 518$ de 25 de março de 2004 do Ministério da Saúde, a qual estabelece os procedimentos e responsabilidades relativas ao controle e vigilância da qualidade da água para o consumo humano e seu padrão de potabilidade, determina além do valor máximo permitido para o benzeno na água potável $\left(0,005 \mathrm{mg} . \mathrm{l}^{-1}\right)$, valores para o tolueno $\left(0,170 \mathrm{mg} . \mathrm{l}^{-1}\right)$, o etilbenzeno $\left(0,200 \mathrm{mg} . \mathrm{l}^{-1}\right)$ e os xilenos $\left(0,300 \mathrm{mg} \cdot \mathrm{l}^{-1}\right)$.

Embora em nenhuma das condições de operação do reator tenha-se obtido concentrações de benzeno dentro do estabelecido pelo Ministério da saúde (Tabela 19), as eficiências obtidas, foram ainda, consideradas satisfatórias, uma vez que o benzeno 
tem sido relatado como um dos compostos de BTEX menos biodegradável anaerobicamente (Burland e Edwards, 1999).

Os efluentes referentes às alimentações com tolueno e m-xileno apresentaram concentrações dentro dos padrões estabelecidos pelo Ministério da Saúde (Tabela 19). Quando o reator foi alimentado com $33,3 \mathrm{mg} / \mathrm{L}$ de etilbenzeno, detectou-se residual de 0,4mg/L deste composto no efluente. Este residual corresponde ao dobro da concentração de etilbenzeno permitida pelo Ministério da Saúde nos corpos d'agua, para o padrão de potabilidade. A presença de concentrações residuais de benzeno e etilbenzeno, acima dos padrões, mostra a necessidade da utilização de outras técnicas de tratamentos, como por exemplo, o tratamento físico (adsorção com carvão ativado, stripping), ou químico (ozônio, peróxido de hidrogênio, hipoclorito de sódio), para que estes compostos possam ser devidamente removidos (Ribeiro, 2005), caso o objetivo da utilização do efluente vise alcançar os padrões de potabilidade.

Muitas vezes, benzeno, tolueno, etilbenzeno e xilenos, ocorrem juntos na natureza, como é o caso do petróleo e da gasolina. Por este motivo, avaliou-se, também, a capacidade do biofilme em remover estes compostos quando os mesmos estivessem juntos. Assim, após a alimentação com cada um dos hidrocarbonetos, separadamente, o reator foi alimentado com substrato contendo aproximadamente, $5 \mathrm{mg} / \mathrm{L}$ de cada um dos hidrocarbonetos, gerando concentração final de aproximadamente 26,5mg/L de BTEX. Nesta solução, além do $m$-xileno, anteriormente analisado, foram, também, adicionados $o$-xileno e $p$-xileno. Estes compostos foram analisados conjuntamente devido à proximidade dos tempos de retenção de $m$-xileno e $p$-xileno na coluna cromatográfica, gerando a superposição dos picos produzidos durante as análises, e à limitação da coluna utilizada para separar os mesmos.

Eficiência de remoção de 98,8\% de BTEX foi obtida durante o perfil para esta condição (Tabela 19). As concentrações efluentes de tolueno, etilbenzeno e, $o-m-p$ xilenos apresentaram-se dentro dos padrões permitidos pelo Ministério da Saúde para estes compostos, sendo que o residual observado no efluente $(0,31 \mathrm{mg} / \mathrm{L})$ deveu-se, principalmente, à presença de benzeno, constatando a maior recalcitrância deste composto. Estes resultados demonstram que, concentrações mais baixas dos hidrocarbonetos foram mais facilmente removidas, gerando efluentes mais satisfatórios.

Em todos trabalhos realizados com RAHLF tratando BTEX (Nardi 2002, Ribeiro 2005, Cattony 2005, Fernandes 2005), incluindo o presente estudo, as concentrações de BTEX utilizadas, que variaram de $1,5 \mathrm{mg} / \mathrm{L}$ a $41,4 \mathrm{mg} / \mathrm{L}$, não 
apresentaram toxicidade para os organismos presentes nos biofilmes, mostrando a elevada adaptação, das células do inóculo utilizado, a estes compostos, nesta configuração de reator. Neste ponto de vista, Shim e Yang (1999), também relataram a maior tolerância de células imobilizadas, quando comparada a células suspensas, a elevadas concentrações de BTEX. 


\subsubsection{Operação do reator RAHLF2}

Durante a operação do RAHLF1, o biofilme foi continuamente submetido à presença dos diferentes hidrocarbonetos, o que resultou em biofilme bem adaptado e capaz de produzir elevadas eficiências de remoção, de etanol, nitrato e BTEX. No entanto, esta capacidade de remoção, pode ter sido consequiência da exposição gradual destas células, a cada um dos hidrocarbonetos, gerando células transformadas, e mais competentes para a biodegradação destes compostos.

Neste ponto de vista, não se poderia concluir, que o inóculo utilizado para gerar o biofilme, foi capaz de biodegradar, por exemplo, somente etilbenzeno, pois anteriormente à submissão do biofilme ao etilbenzeno, as células estiveram em contato com benzeno, tolueno e $m$-xileno. Assim, este contato prévio poderia ser o fator determinante para que estas células fossem capazes de remover o etilbenzeno.

Segundo Alvarez e Vogel (1991) compostos individuais poderiam estimular ou inibir a degradação de outro, pela indução de enzimas, ou atuando como substrato primário estimulando o crescimento microbiano que aumentaria o cometabolismo de um outro composto. Por outro lado, a presença de um composto poderia apresentar efeito inibitório devido à toxicidade, repressão catabólica, inibição competitiva, por enzimas.

Assim, a estratégia de operação do RALF2 foi modificada, objetivando-se avaliar a capacidade da cultura em remover os hidrocarbonetos, separadamente, sem que esta cultura tenha tido contato prévio com outros hidrocarbonetos. Neste reator, o meio suporte foi removido todas as vezes que um dos compostos de BTEX foi utilizado na alimentação do reator.

Além de avaliar a capacidade do biofilme em promover a remoção de BTEX, buscou-se, também, avaliar a remoção destes compostos, separadamente, e em curtos períodos de operação.

Geralmente, nos trabalhos realizados com reatores com biomassa imobilizada, o biofilme passa pelas fases de formação e adaptação. Em alguns trabalhos, os reatores são previamente alimentados com substrato sintético composto por fontes complexas como lipídios, glicídios e proteínas, que favorecem o crescimento da biomassa. Posteriormente, o biofilme formado é submetido a concentrações progressivas de hidrocarbonetos, para que as células possam ser adaptadas ao meio.

No presente estudo, já se tinha conhecimento do rápido crescimento celular da biomassa $(\mathrm{Tg}=13,9$ horas, em presença de etilbenzeno e etanol). Como as células já 
tinham sido submetidas à presença contínua do hidrocarboneto, durante as fases de purificação e manutenção da cultura, foi observada formação rápida de biofilme denso na matriz de poliuretano, já nos primeiros dias, após a imobilização da cultura.

\subsubsection{Alimentação do RAHLF2 com etilbenzeno em diferentes concentrações}

O esquema de operação deste reator, mostrando as concentrações dos hidrocarbonetos avaliados e o tempo de operação com cada um destes compostos estão representado na Figura 3, do capítulo Material e Métodos. Os valores de todas as medidas realizadas dos parâmetros de monitoramento deste reator estão apresentados no Apêndice H. Os perfis espaciais referentes aos hidrocarbonetos estão disponíveis no Apêndice I.

A Tabela 20 e Figura 38 apresentam os resultados dos parâmetros de monitoramento obtidos durante o período de operação do reator alimentado com diferentes concentrações de etilbenzeno. As eficiências médias de remoção da matéria orgânica $\left(\mathrm{DQO}_{\mathrm{f}}\right)$ e nitrato $\left(\mathrm{N}^{-\mathrm{NO}_{3}}{ }^{-}\right)$foram de $92,7 \%$ e $89,0 \%$, respectivamente. De forma geral, nesta fase de operação, o RAHLF2 apresentou comportamento muito semelhante ao reator RAHLF1. As baixas flutuações destes parâmetros durante todo o período de operação com etilbenzeno, indicaram a boa estabilidade do reator (Figura $38)$.

Tabela 20 - Valores dos parâmetros de monitoramento do RAHLF2, obtidos durante operação com etilbenzeno.

\begin{tabular}{lccccc}
\hline \multicolumn{1}{c}{ Parâmetros } & \multicolumn{2}{c}{ Afluente } & \multicolumn{2}{c}{ Efluente } & $\begin{array}{c}\text { Eficiência } \\
\text { Média de } \\
\end{array}$ \\
& Média & Variação & Média & Variação & $\begin{array}{c}\text { Remocão } \\
\text { (\%) }\end{array}$ \\
\hline & & & & & \\
$\mathrm{DQO}_{\text {bruta }}(\mathrm{mg} / \mathrm{L})$ & 971,2 & $832,9-1253,4$ & 99,8 & $51,4-219,8$ & 89,7 \\
$\left.\mathrm{DQO}_{\text {filtrada }}(\mathrm{mg} / \mathrm{L})^{1}\right)$ & 956,3 & $809,4-1205,7$ & 69,7 & $20,8-196,5$ & 92,7 \\
$\mathrm{~N}_{\mathrm{NO}}{ }_{3}^{-}(\mathrm{mg} / \mathrm{L})$ & 390,1 & $325,8-387,5$ & 42,9 & $8,0-167,2$ & 89,0 \\
$\mathrm{pH}$ & 22,3 & $6,9-7,5$ & 33,3 & $68,2-9,4$ & - \\
$\mathrm{SSV}(\mathrm{mg} / \mathrm{L})$ & 7,2 & $7,0-44$ & 8,7 & $5,0-57,0$ & - \\
\hline
\end{tabular}



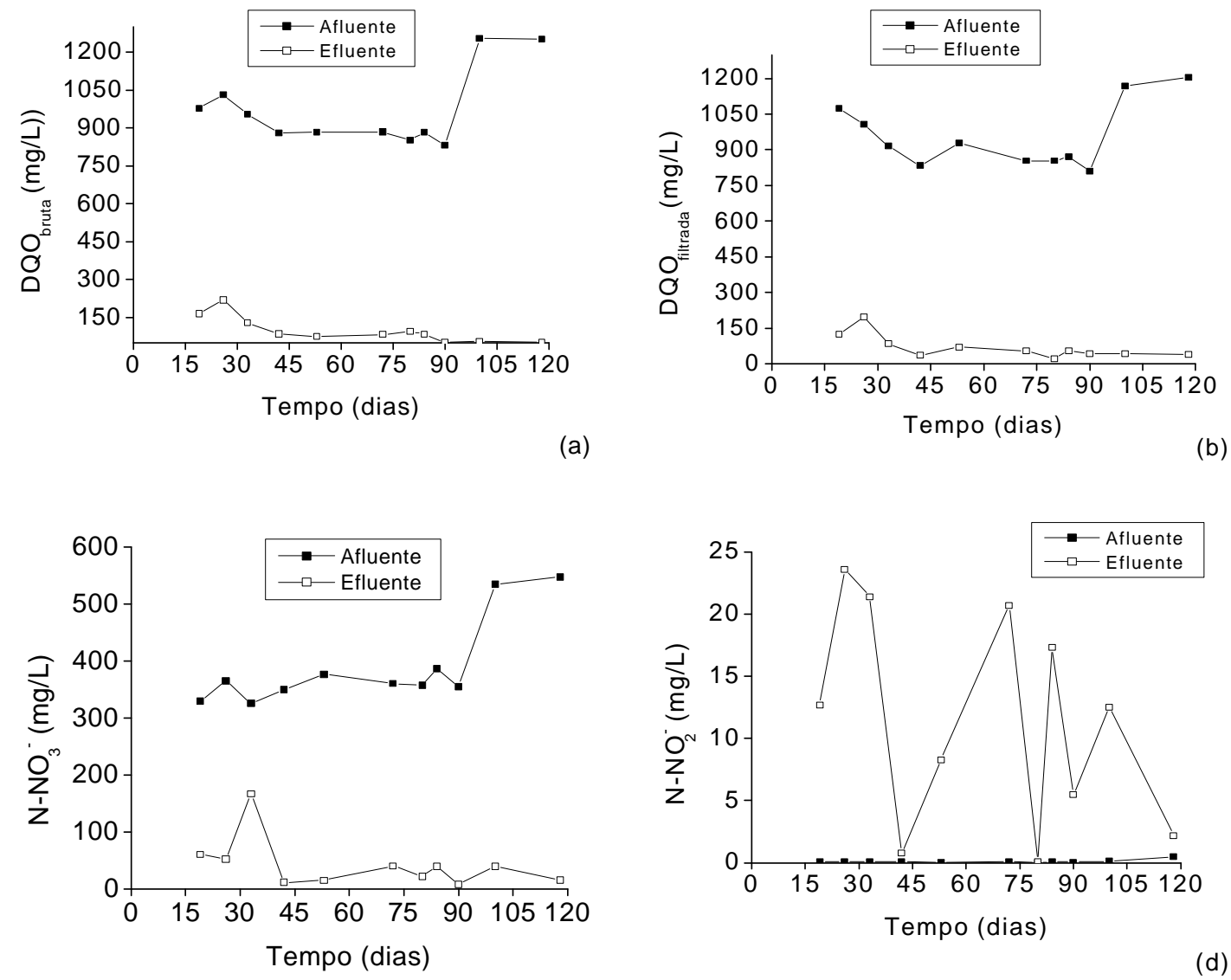

(d)
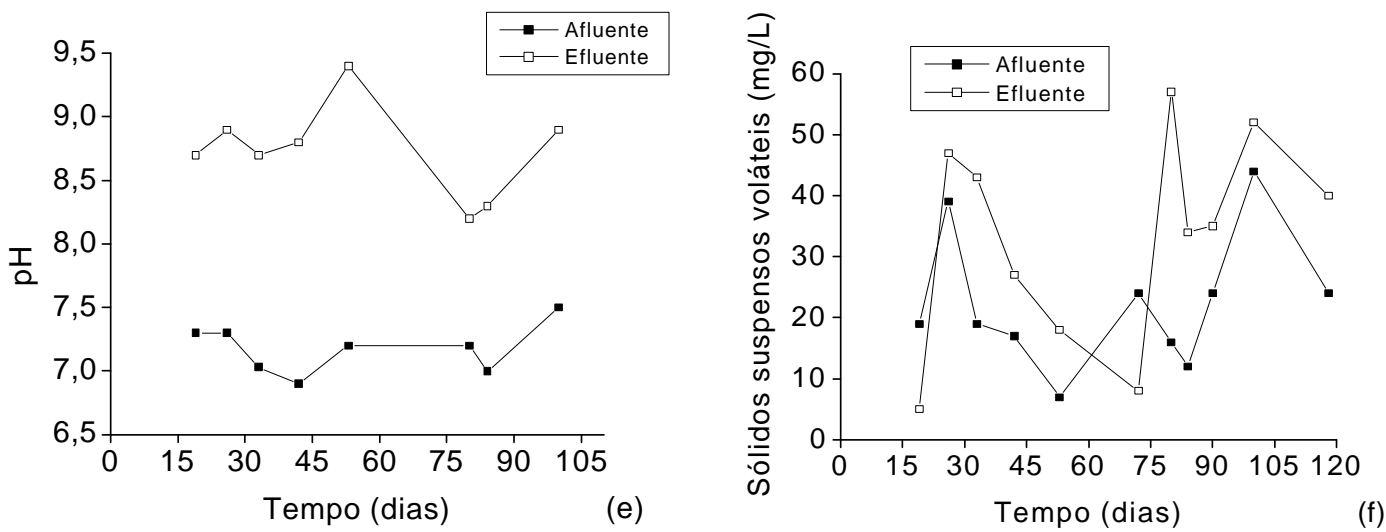

Figura 38 -Variação da concentração de $\mathrm{DQO}_{\mathrm{b}}(\mathrm{a}), \mathrm{DQO}_{\mathrm{f}}(\mathrm{b}) ; \mathrm{N}^{-\mathrm{NO}_{3}}{ }^{-}$(c), $\mathrm{N}-\mathrm{NO}_{2}{ }^{-}(\mathrm{d}), \mathrm{pH}$ (e) e SSV(f). RAHLF 2 alimentado com etilbenzeno.

A Tabela 21 e as figuras 39 a 41 referem-se aos comentários relativos aos perfis espaciais realizados com diferentes concentrações de etilbenzeno. 
Tabela 21 - Valores das concentrações afluentes e efluentes dos parâmetros avaliados nos perfis com diferentes concentrações de etilbenzeno.

\begin{tabular}{|c|c|c|c|}
\hline \multirow[t]{2}{*}{ Parâmetro } & \multicolumn{2}{|c|}{$\begin{array}{c}\text { Concentração } \\
(\mathrm{mg} / \mathrm{L})\end{array}$} & \multirow{2}{*}{$\begin{array}{l}\text { Eficiência Média de } \\
\text { Remoção } \\
(\%)\end{array}$} \\
\hline & Afluente & Efluente & \\
\hline Etilbenzeno & 13,1 & 0,08 & 99,4 \\
\hline $\mathrm{DQO}_{\text {Filtrada }}(\mathrm{mg} / \mathrm{L})$ & 832,9 & 36,1 & 95,7 \\
\hline $\mathrm{N}-\mathrm{NO}_{3}^{-}(\mathrm{mg} / \mathrm{L})$ & 349,6 & 11,5 & 96,7 \\
\hline $\mathrm{N}-\mathrm{NO}_{2}^{-}(\mathrm{mg} / \mathrm{L})$ & 0,0 & 0,78 & - \\
\hline Ácido acético (mg/L) & $*$ & $*$ & $*$ \\
\hline Etilbenzeno & 15,1 & 0,01 & 99,9 \\
\hline $\mathrm{DQO}_{\text {Filtrada }}(\mathrm{mg} / \mathrm{L})$ & 809,4 & 42 & 94,8 \\
\hline $\mathrm{N}-\mathrm{NO}_{3}^{-}(\mathrm{mg} / \mathrm{L})$ & 355,2 & 8,0 & 97,8 \\
\hline $\mathrm{N}-\mathrm{NO}_{2}^{-}(\mathrm{mg} / \mathrm{L})$ & 0,06 & 5,5 & - \\
\hline Ácido acético (mg/L) & $*$ & $*$ & $*$ \\
\hline Etilbenzeno & 31,1 & 0,2 & 99,4 \\
\hline $\mathrm{DQO}_{\text {Filtrada }}(\mathrm{mg} / \mathrm{L})$ & 1205,7 & 38,5 & 96,8 \\
\hline $\mathrm{N}-\mathrm{NO}_{3}{ }^{-}(\mathrm{mg} / \mathrm{L})$ & 547,9 & 15,5 & 97,2 \\
\hline $\mathrm{N}-\mathrm{NO}_{2}^{-}(\mathrm{mg} / \mathrm{L})$ & 0,5 & 2,2 & - \\
\hline Ácido acético (mg/L) & * & * & $*$ \\
\hline
\end{tabular}

* valores abaixo do limite de detecção da curva de calibração para ácido acético (6,0 $\mathrm{mg} / \mathrm{L})$

Nos perfis, a eficiência média de remoção da matéria orgânica $\left(\mathrm{DQO}_{\mathrm{f}}\right)$ foi de 95,8\% para as três concentrações de etilbenzeno analisadas. Ácido acético foi produzido e consumido ao longo do reator, em todas as condições de alimentação desta fase de operação (Figura 39), demonstrando a boa estabilidade do reator. 

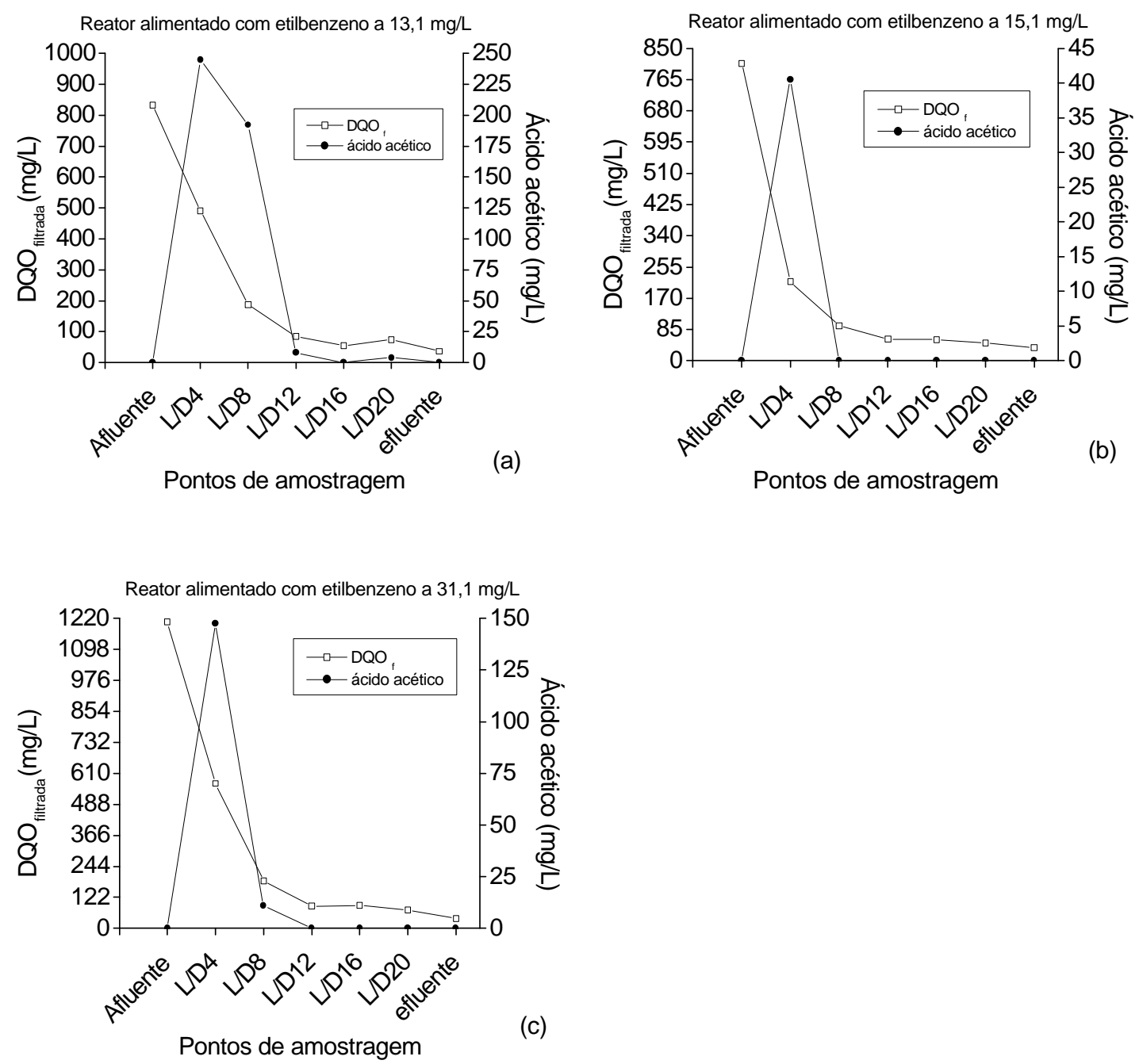

Figura 39 - Variação espacial da concentração da matéria orgânica $\left(\mathrm{DQO}_{\mathrm{f}}\right)$ e ácido acético ao longo do reator RAHLF2 alimentado com etilbenzeno a 13,1 mg/L (a), 15,1 mg/L (b) e 31,1 $\mathrm{mg} / \mathrm{L}(\mathrm{c})$.

A variação da concentração de etilbenzeno, ao longo do reator está representada na Figura 40. Elevadas porcentagens de remoção de etilbenzeno foram obtidas em todas as condições de alimentação, e os residuais observados nos efluentes, nas diferentes condições, correspondem ao estabelecido para o valor máximo permitido deste composto nas águas de abastecimento que é de $0,2 \mathrm{mg} / \mathrm{L}$ (Tabela 21), conforme determinado pelo Ministério da Saúde (padrão de potabilidade) 


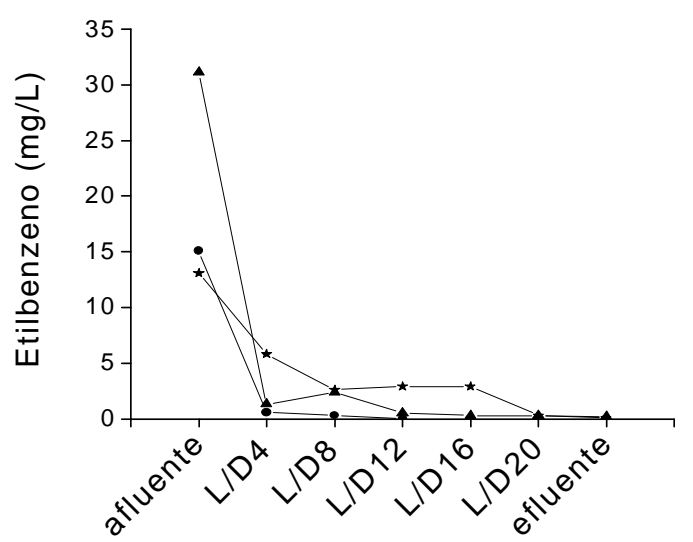

Pontos de amostragens

Figura 40- Variação espacial da concentração de etilbenzeno no RAHLF2.

A eficiência média de remoção de nitrato, obtida durante os perfis, foi de 97,2\% $\pm 0,5$. Nitrito $\left(\mathrm{N}^{-\mathrm{NO}_{2}}{ }^{-}\right)$foi produzido, e quase que totalmente consumido ao longo do reator, gerando, baixos valores residuais no efluente. (Figura 41).

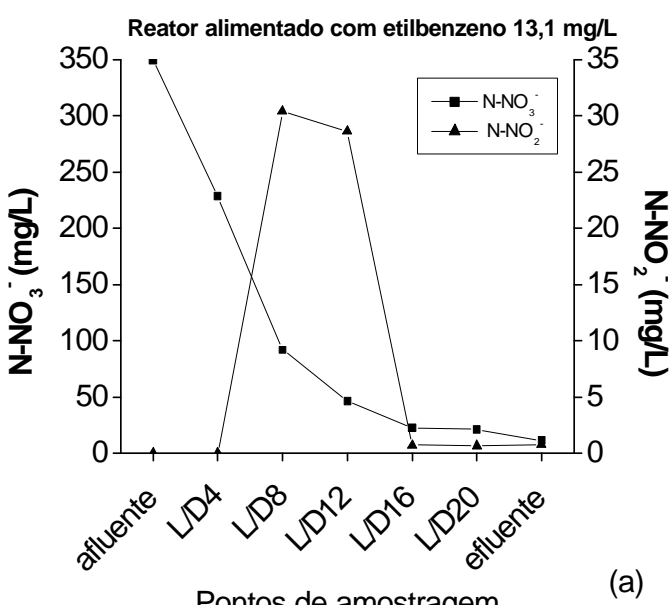

Pontos de amostragem

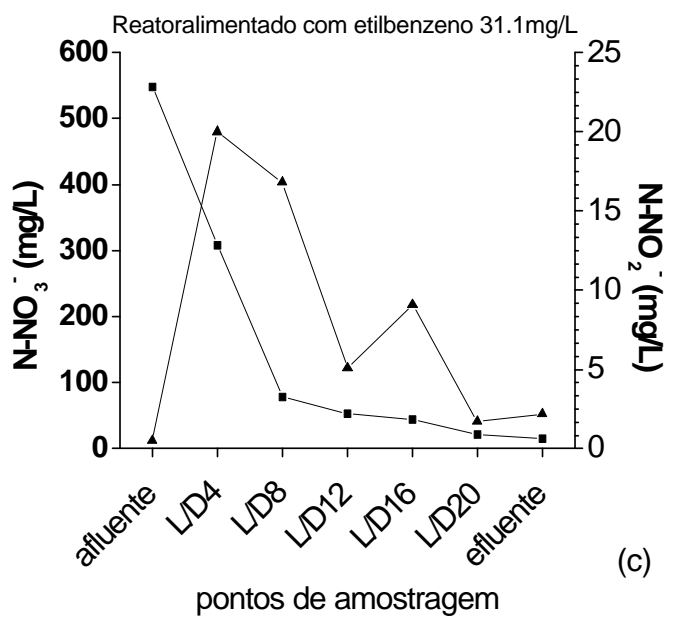

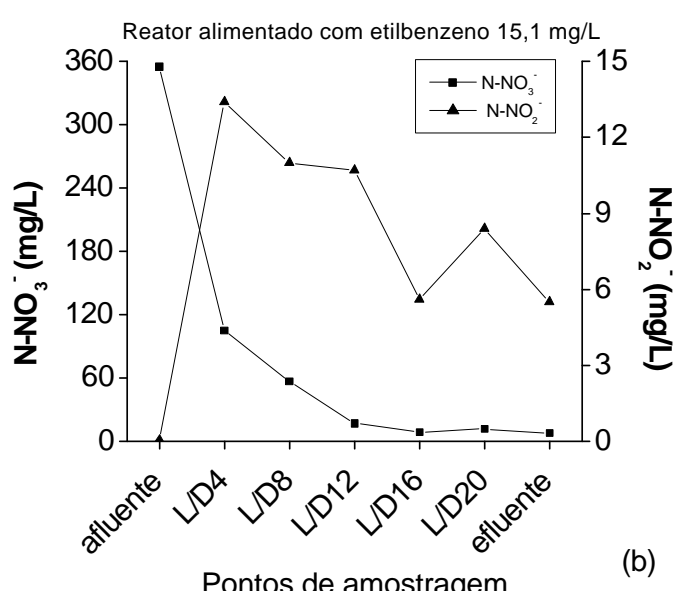

Figura 41 - Variação espacial da concentração de nitrato $\left(\mathrm{N}-\mathrm{NO}_{3}{ }^{-}\right)$e nitrito $\left(\mathrm{N}-\mathrm{NO}_{2}{ }^{-}\right)$do reator RAHLF2 alimentado com etilbenzeno a $13,1 \mathrm{mg} / \mathrm{L}$ (a), 15,1 $\mathrm{mg} / \mathrm{L}$ (b) e $31,1 \mathrm{mg} / \mathrm{L}$ (c). 
Elevadas eficiências de remoção obtidas para etilbenzeno, matéria orgânica, e nitrato, assim como, a produção e consumo de nitrito e ácido acético, demonstraram a boa estabilidade do reator nesta primeira fase de operação.

\subsubsection{Alimentação do RAHLF2 com tolueno, benzeno, $m$-xileno, $o$-xileno, $p$-xileno e BTEX}

Devido ao pouco tempo de operação do reator durante a alimentação com tolueno, benzeno, xilenos e BTEX, e às poucas amostragens realizadas para os parâmetros de monitoramento, neste item, não será abordada a discussão a respeito da estabilidade do reator baseada nos parâmetros de monitoramento (ácidos voláteis totais, alcalinidade, $\mathrm{pH}$, e sólidos suspensos voláteis). A seguinte discussão considera somente os resultados obtidos dos perfis, realizado ao final da alimentação do reator com cada um dos compostos.

A Tabela 22 apresenta as concentrações dos parâmetros avaliados no afluente e efluente do reator durante a operação do mesmo com os hidrocarbonetos. 
Tabela 22 - Concentrações afluentes e efluentes dos parâmetros avaliados nos perfis do RAHLF2.

\begin{tabular}{|c|c|c|c|c|}
\hline \multirow[t]{2}{*}{ Parâmetros } & \multirow{2}{*}{$\begin{array}{c}\text { Tempo de } \\
\text { operação } \\
\text { (dias) }\end{array}$} & \multicolumn{2}{|c|}{$\begin{array}{l}\text { Concentração } \\
(\mathrm{mg} / \mathrm{L})\end{array}$} & \multirow{2}{*}{$\begin{array}{c}\text { Eficiência } \\
\text { Média de } \\
\text { Remoção }(\%)\end{array}$} \\
\hline & & Afluente & Efluente & \\
\hline Tolueno & 34 & 7,6 & 0,1 & 98,7 \\
\hline $\mathrm{DQO}_{\text {Fil;trada }}(\mathrm{mg} / \mathrm{L})$ & & 710,8 & 179,2 & 74,8 \\
\hline $\mathrm{N}-\mathrm{NO}_{3}{ }^{-}(\mathrm{mg} / \mathrm{L})$ & & 534,5 & 103,1 & 80,7 \\
\hline $\mathrm{N}-\mathrm{NO}_{2}^{-}(\mathrm{mg} / \mathrm{L})$ & & 0,0 & 79,2 & - \\
\hline Ácido acético (mg/L) & & 1,6 & 8,3 & - \\
\hline Tolueno & 17 & 27,8 & 0,3 & 98,9 \\
\hline $\mathrm{DQO}_{\text {Fil;trada }}(\mathrm{mg} / \mathrm{L})$ & & 1240,8 & 345,1 & 72,2 \\
\hline $\mathrm{N}-\mathrm{NO}_{3}^{-}(\mathrm{mg} / \mathrm{L})$ & & 451,4 & 6,1 & 96,7 \\
\hline $\mathrm{N}-\mathrm{NO}_{2}^{-}(\mathrm{mg} / \mathrm{L})$ & & 0,0 & 0,0 & - \\
\hline Ácido acético (mg/L) & & 6,25 & 286,4 & - \\
\hline Benzeno & 18 & 15,1 & 1,6 & 89,4 \\
\hline $\mathrm{DQO}_{\text {Fil;trada }}(\mathrm{mg} / \mathrm{L})$ & & 1270,0 & 128,2 & 89,9 \\
\hline $\mathrm{N}-\mathrm{NO}_{3}{ }^{-}(\mathrm{mg} / \mathrm{L})$ & & 524,5 & 11,5 & 97,8 \\
\hline $\mathrm{N}-\mathrm{NO}_{2}^{-}(\mathrm{mg} / \mathrm{L})$ & & 0,02 & 0,0 & - \\
\hline Ácido acético (mg/L) & & 0,0 & 0,0 & - \\
\hline Benzeno & 17 & 41,4 & 4,4 & 89,4 \\
\hline $\mathrm{DQO}_{\text {Fil;trada }}(\mathrm{mg} / \mathrm{L})$ & & 1322,3 & 142,8 & 89,2 \\
\hline $\mathrm{N}-\mathrm{NO}_{3}^{-}{ }^{-}(\mathrm{mg} / \mathrm{L})$ & & 520,0 & 2,0 & 99,6 \\
\hline $\mathrm{N}-\mathrm{NO}_{2}^{-}(\mathrm{mg} / \mathrm{L})$ & & 0,0 & 0,0 & - \\
\hline Ácido acético (mg/L) & & 0,0 & 62,3 & - \\
\hline$m$-xileno & 13 & 9,46 & 0,5 & 94,6 \\
\hline $\mathrm{DQO}_{\text {Fil;trada }}(\mathrm{mg} / \mathrm{L})$ & & 1473,7 & 413,6 & 71,9 \\
\hline $\mathrm{N}-\mathrm{NO}_{3}{ }^{-}(\mathrm{mg} / \mathrm{L})$ & & 534,5 & 39,6 & 92,6 \\
\hline $\mathrm{N}-\mathrm{NO}_{2}^{-}(\mathrm{mg} / \mathrm{L})$ & & 0,0 & 0,0 & - \\
\hline Ácido acético (mg/L) & & 0,0 & 286,4 & - \\
\hline$m$-xileno & 15 & 28,4 & 0,3 & 98,9 \\
\hline $\mathrm{DQO}_{\text {Fil } \text { trada }}(\mathrm{mg} / \mathrm{L})$ & & 1619,3 & 521,9 & 67,8 \\
\hline $\mathrm{N}-\mathrm{NO}_{3}^{-}(\mathrm{mg} / \mathrm{L})$ & & 417,5 & 4,3 & 99,0 \\
\hline $\mathrm{N}-\mathrm{NO}_{2}^{-}(\mathrm{mg} / \mathrm{L})$ & & 0,12 & 0,0 & - \\
\hline Ácido acético (mg/L) & & 15,2 & 502,9 & - \\
\hline$o$-xileno & 15 & 28,5 & 1,8 & 93,7 \\
\hline $\mathrm{DQO}_{\text {Fil;trada }}(\mathrm{mg} / \mathrm{L})$ & & 1258,5 & 163,2 & 87,0 \\
\hline $\mathrm{N}-\mathrm{NO}_{3}{ }^{-}(\mathrm{mg} / \mathrm{L})$ & & 516,7 & 11,5 & 97,8 \\
\hline $\mathrm{N}-\mathrm{NO}_{2}^{-}(\mathrm{mg} / \mathrm{L})$ & & 0,03 & 0,0 & - \\
\hline Ácido acético (mg/L) & & 0,0 & 0,0 & - \\
\hline$p$-xileno & 15 & 32,1 & 0,1 & 99,7 \\
\hline $\mathrm{DQO}_{\text {Fil;trada }}(\mathrm{mg} / \mathrm{L})$ & & 1648,5 & 208,3 & 87,4 \\
\hline $\mathrm{N}-\mathrm{NO}_{3}{ }^{-}(\mathrm{mg} / \mathrm{L})$ & & 510,0 & 28,3 & 94,5 \\
\hline $\mathrm{N}-\mathrm{NO}_{2}^{-}(\mathrm{mg} / \mathrm{L})$ & & 0,0 & 0,2 & - \\
\hline Ácido acético (mg/L) & & 0,0 & 0,0 & - \\
\hline BTEX & 15 & 32,9 & $1,4^{*}$ & 95,7 \\
\hline $\mathrm{DQO}_{\text {Fil } \text { trada }}(\mathrm{mg} / \mathrm{L})$ & & 1642,5 & 169,4 & 89,7 \\
\hline $\mathrm{N}^{-\mathrm{NO}_{3}}{ }^{-}(\mathrm{mg} / \mathrm{L})$ & & 574,6 & 85,1 & 85,2 \\
\hline $\mathrm{N}-\mathrm{NO}_{2}^{-}(\mathrm{mg} / \mathrm{L})$ & & 0,5 & 64,1 & - \\
\hline Ácido acético (mg/L) & 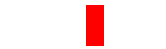 & 6,2 & 18,3 & - \\
\hline
\end{tabular}


Nos períodos de alimentação do RAHLF2 com tolueno, benzeno, $m$-xileno, $o$ xileno, $p$-xileno e BTEX, o consumo da matéria orgânica levou à formação de ácido acético em todas as condições de alimentação (Figura 42). Com a diminuição do tempo de operação do reator, as eficiências de remoção da matéria orgânica $\left(\mathrm{DQO}_{\mathrm{f}}\right)$ foram menores.

Elevadas concentrações de ácido acético foram detectadas no efluente, ao final da alimentação do reator com tolueno, $m$-xileno e benzeno, cujos valores foram de $286,8 \mathrm{mg} / \mathrm{L}, 502,9 \mathrm{mg} / \mathrm{L}$ e $62,3 \mathrm{mg} / \mathrm{L}$, respectivamente (Tabela 22). Nestas mesmas condições, as concentrações de nitrato $\left(\mathrm{N}^{-N_{3}}{ }_{3}{ }^{-}\right)$, observadas no quarto seguimento do reator (L/D16), foram de 9,3 mg/L, 6,8 mg/L e 7,1 mg/L, para as alimentações com tolueno, $m$-xileno e benzeno, respectivamente (Figura 43). Este comportamento já havia sido observado no RAHLF1, quando o mesmo foi operado por períodos de 15 dias. Assim, o acúmulo de ácido acético foi, mais uma vez, associado à instabilidade do reator, ao esgotamento do aceptor final de elétrons (nitrato), e a dificuldade da biomassa se adaptar às novas condições, em pouco tempo de operação do reator. 


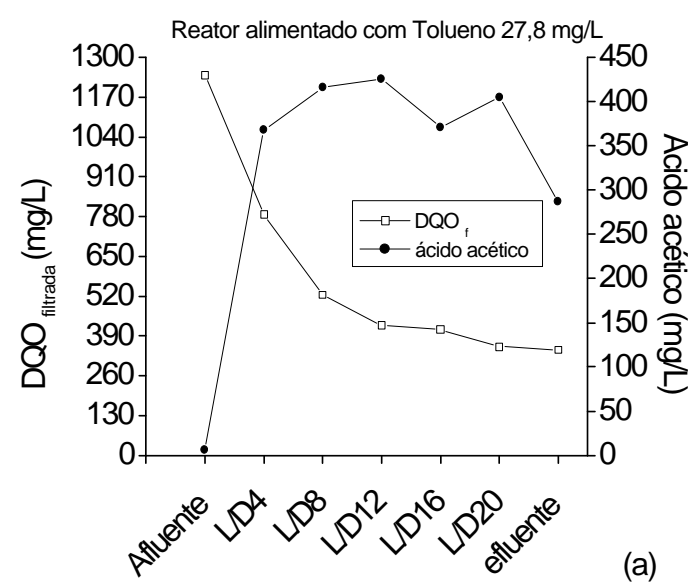

Pontos de amostragem
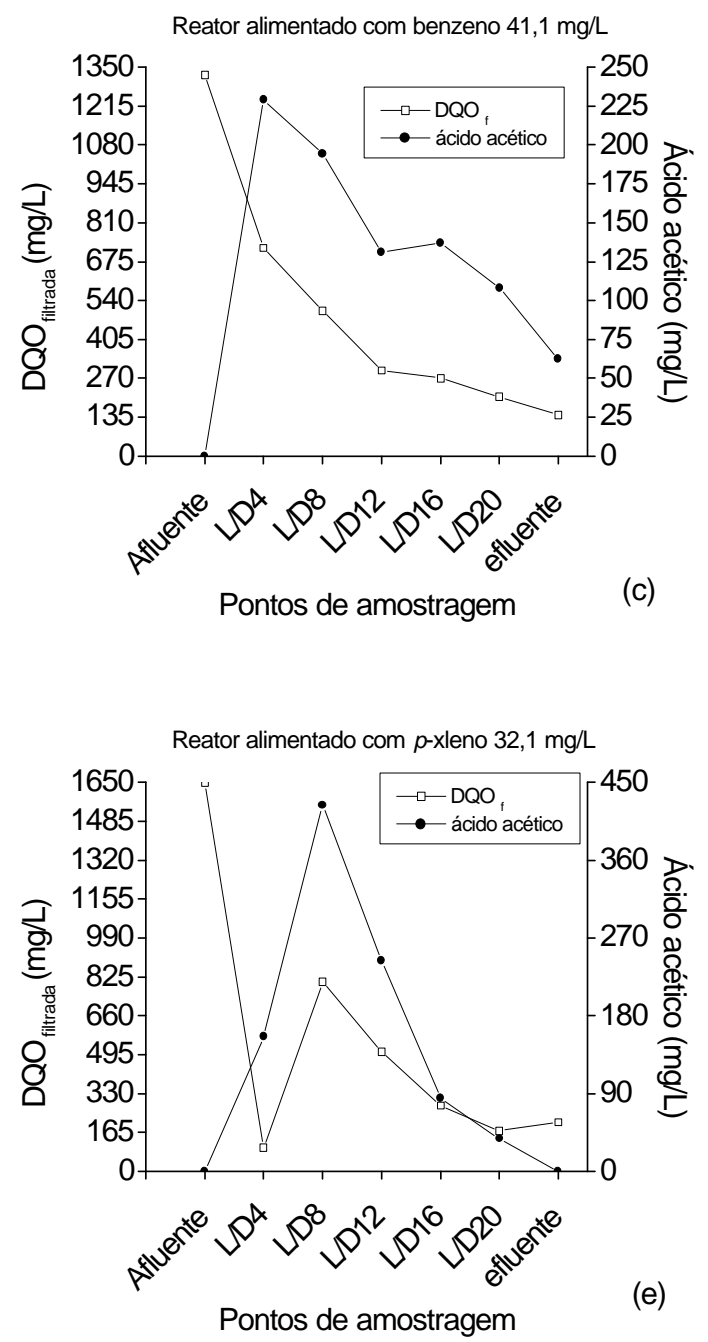
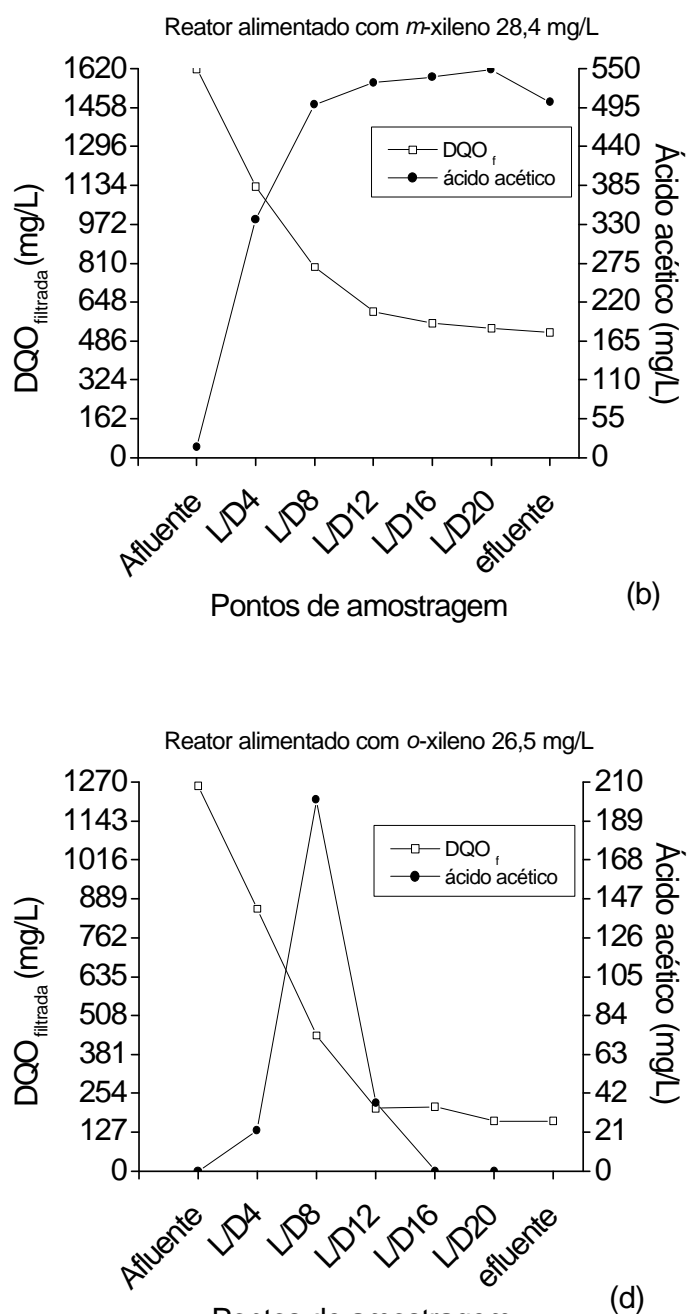

Pontos de amostragem

(d)

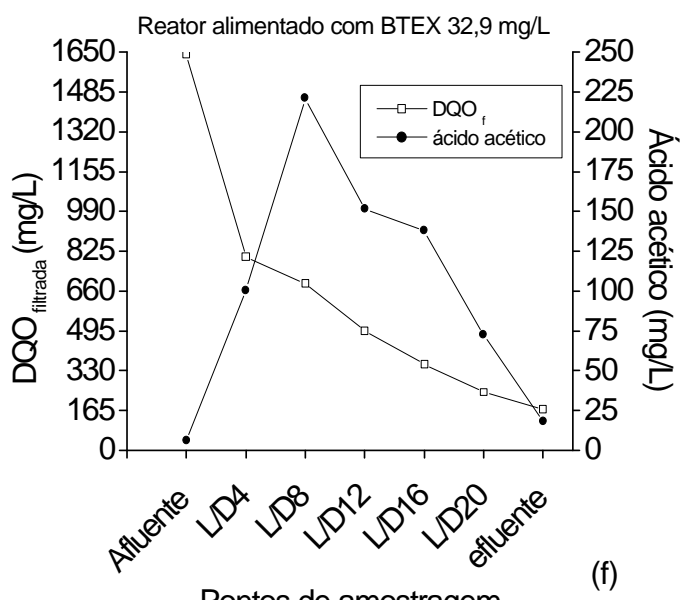

Pontos de amostragem

Figura 42 - Variação espacial da concentração da matéria orgânica $\left(\mathrm{DQO}_{\mathrm{f}}\right)$ e ácido acético do RAHLF2 alimentado com tolueno (a), m-xileno (b), benzeno (c), o-xileno (d), p-xileno (e) e $\operatorname{BTEX}(\mathrm{f})$. 

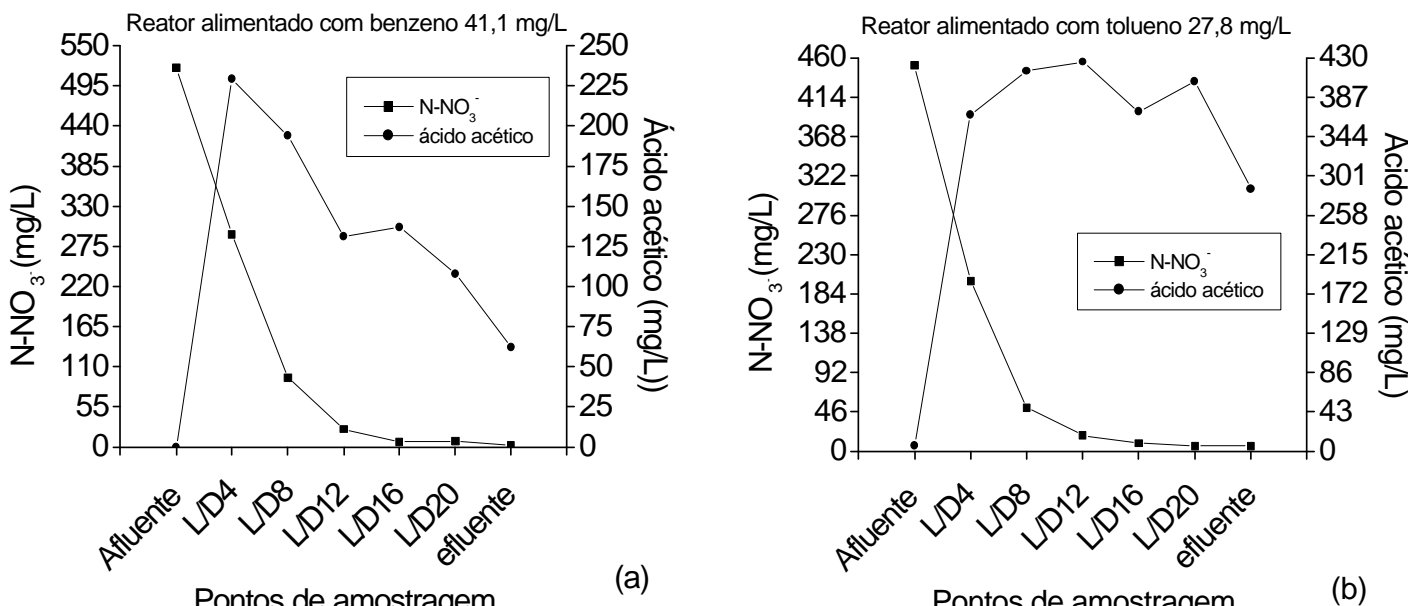

Pontos de amostragem

(a)

Pontos de amostragem

(b)

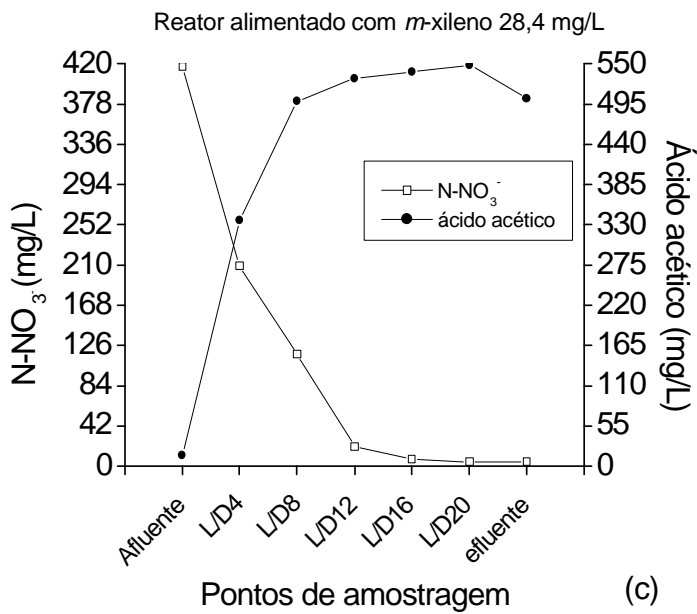

Figura 43 - Variação espacial da concentração de nitrato $\left(\mathrm{N}_{-} \mathrm{NO}_{3}{ }^{-}\right)$e ácido acético do RAHLF2 referente à alimentação com (a) benzeno, (b) tolueno e (c) $m$-xileno

Embora as eficiências de remoção da matéria orgânica $\left(\mathrm{DQO}_{\mathrm{f}}\right)$ tenham sido inferiores nestas condições de alimentação, foram observadas elevadas eficiências de remoção de nitrato $\left(\mathrm{N}-\mathrm{NO}_{3}{ }^{-}\right)$(Tabela 22). Nitrito $\left(\mathrm{N}-\mathrm{NO}_{2}{ }^{-}\right)$foi produzido e consumido ao longo do reator, em todas as condições, exceto para a alimentação com BTEX, sendo detectados 64,1 mg/L N-NO ${ }_{2}^{-}$(Figura 44). 

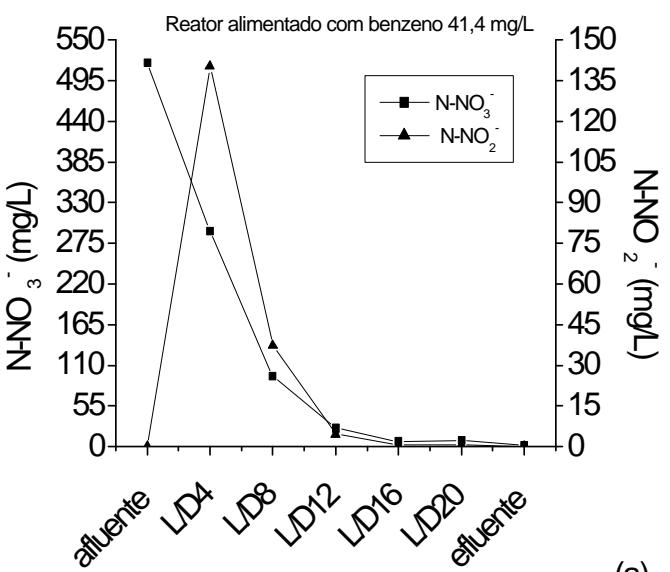

Pontos de amostragem
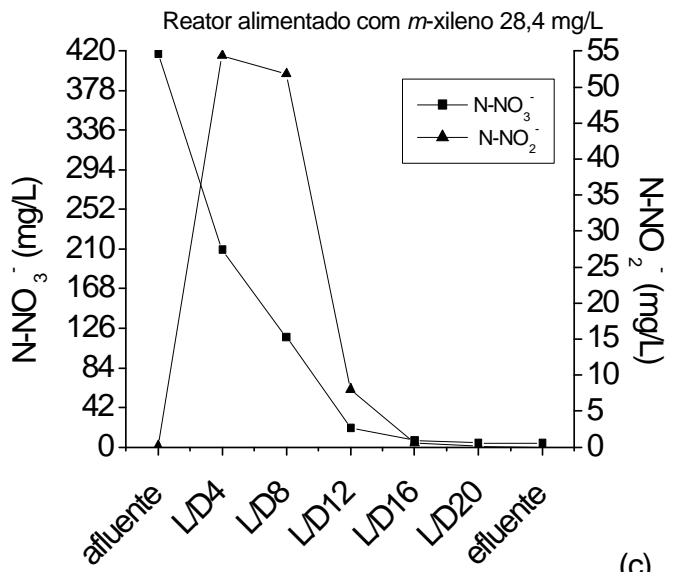

Pontos de amostragem

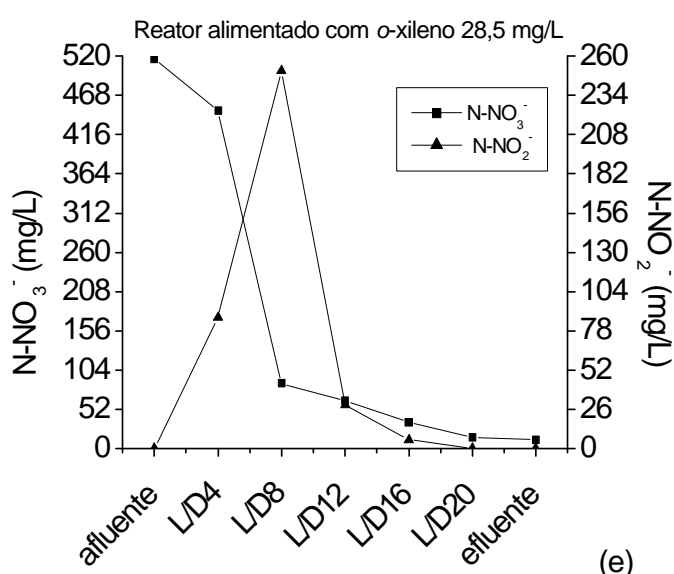

Pontos de amostragem

(c)

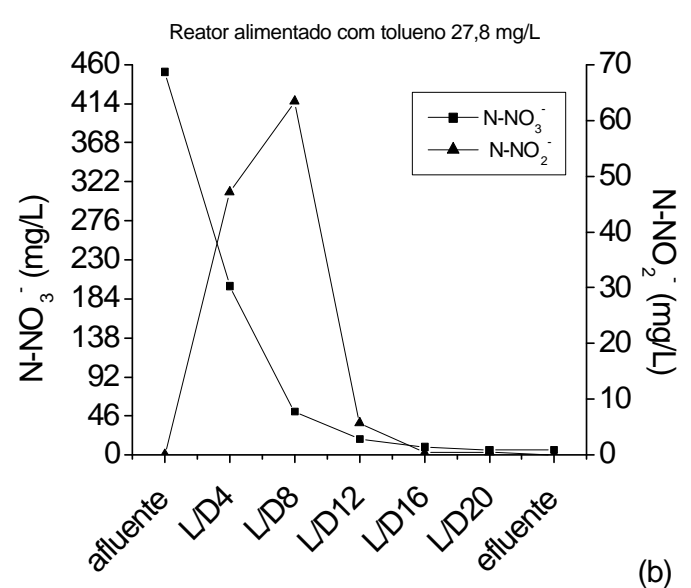

Pontos de amostragem
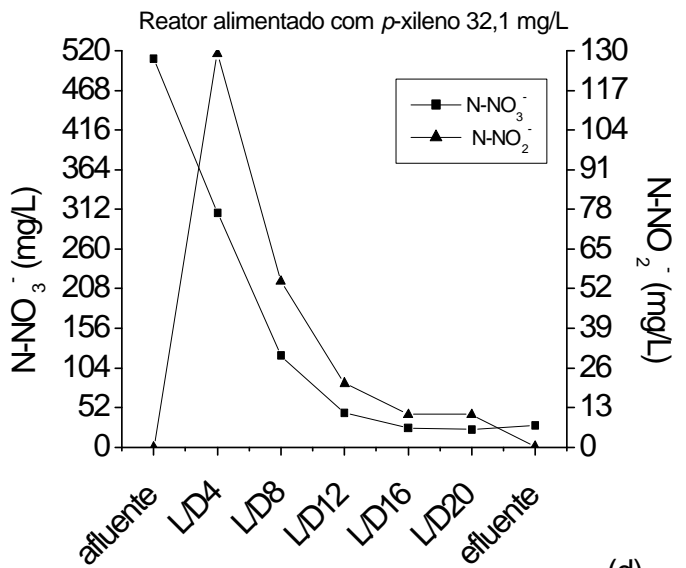

Pontos de amostragem

(d)

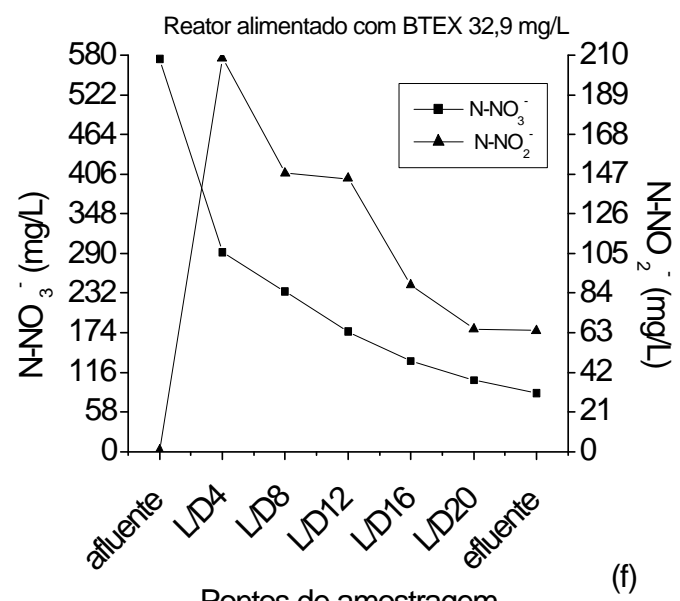

Pontos de amostragem b)

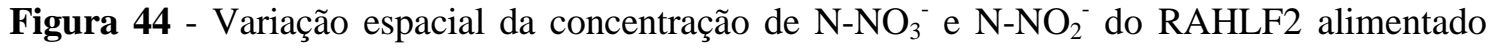
com benzeno (a), tolueno (b), m-xileno (c), p-xileno (d), o-xileno (e), e p-xileno (f).

Diferentemente, ao observado para remoção de matéria orgânica (DQO) foram obtidas elevadas porcentagens de remoções dos hidrocarbonetos, nas diferentes 
condições de alimentação (Tabela 22 e Figura 45). Este fato pode estar relacionado, principalmente, à adaptação prévia sofrida pelas células, uma vez que as mesmas foram purificadas, isoladas, e cultivadas em meio contendo o hidrocarboneto. Outro fator importante, que pode ter contribuído para a maior eficiência de remoção dos hidrocarbonetos, diz respeito à adsorção apresentada pelos compostos de BTEX nestas células (especialmente nos polímeros produzidos), assim como no meio suporte (espuma de poliuretano), disponibilizando o hidrocarboneto para as células a todo o momento e facilitando, também, o processo de adaptação das células a estes compostos.

Todos estes fatores podem ter favorecido o desenvolvimento de células competentes, que foram capazes de sintetizar, prontamente, enzimas necessárias para o processo de biodegradação do hidrocarboneto, quando as mesmas se encontraram em contato com os mesmos, não sendo necessário longos períodos de adaptação.

A adaptação aos hidrocarbonetos foi também verificada quando o reator foi submetido à alimentação com concentrações mais elevadas destes compostos, o que não alterou morfologicamente as células do biofilme. Nestas condições, o exame microscópico das células demonstrou morfologias íntegras, sem qualquer alteração, conforme comentado posteriormente na seção de "análise microscópica".

A Figura 45 mostra as transformações dos hidrocarbonetos, nas diferentes condições de alimentação do reator.

O composto que apresentou menor porcentagem de remoção foi o benzeno $(89,4 \%)$, gerando residual de 4,4mg/L quando o reator foi submetido à concentração de 41,4mg/L (Tabela 22). Mais uma vez, a dificuldade de remoção deste composto, pelos microrganismos do biofilme, foi confirmada. De forma semelhante ao já observado no RAHLF1, o decréscimo da concentração dos hidrocarbonetos ocorreu, principalmente, no primeiro ponto de amostragem $(\mathrm{L} / \mathrm{D}=4)$ (Figura 45$)$. 

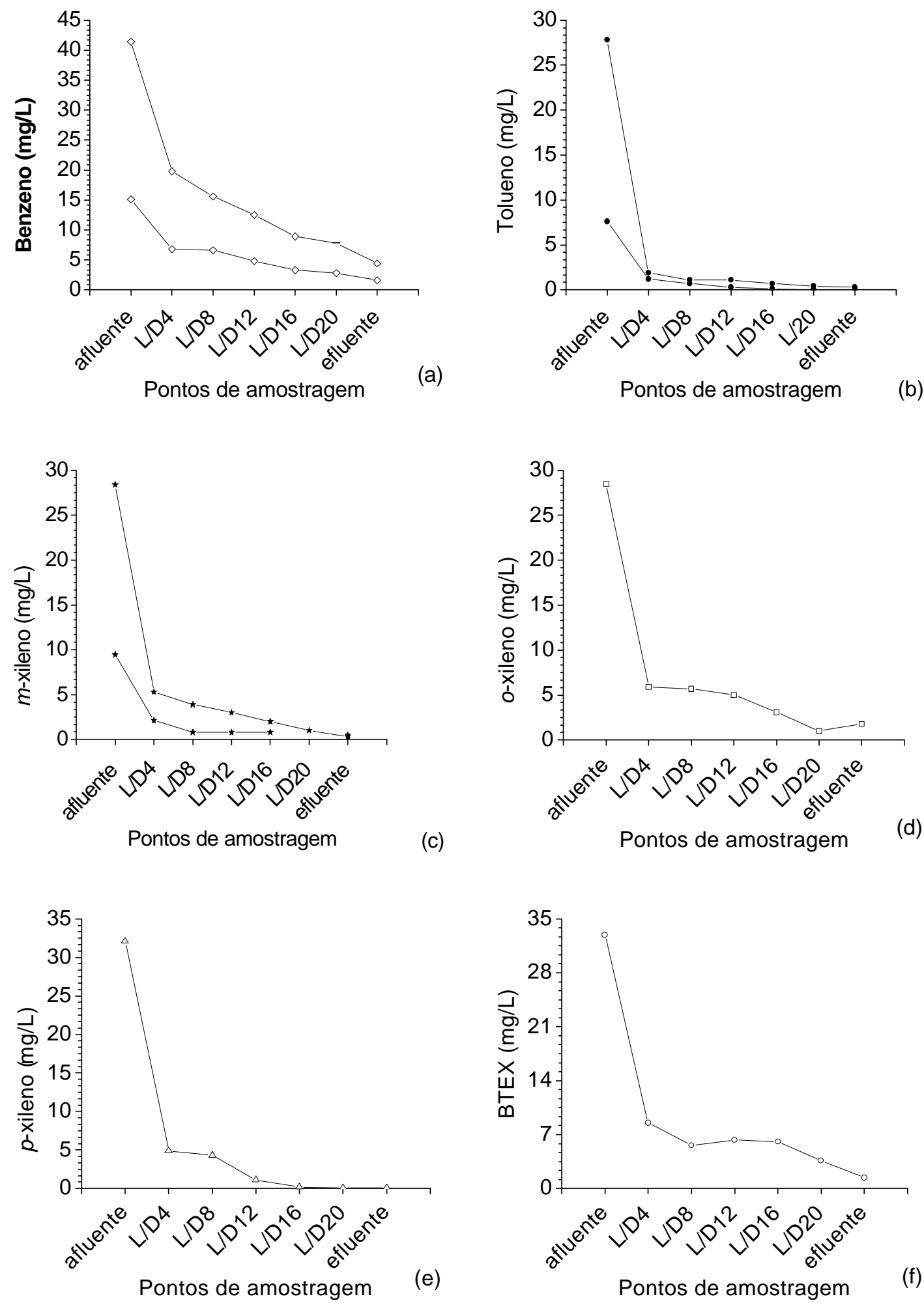

Figura 45 - Variação espacial da concentração dos hidrocarbonetos no RAHLF2 alimentado com benzeno (a), tolueno (b), m-xileno (c), o-xileno (d) p-xileno (e) e BTEX (f).

Embora elevadas porcentagens de remoção de hidrocarbonetos tenham sido obtidas, os efluentes gerados ao final das alimentações com tolueno, benzeno e $o$-xileno (Tabela 22), não atenderam aos padrões de emissão destes compostos nos corpos 
d'agua, no que diz respeito ao padrão de potabilidade, estabelecidos pelo Ministério da saúde, cujas concentrações máximas permitidas para estes compostos é de $0,17 \mathrm{mg} / \mathrm{L}$ de tolueno, $0,005 \mathrm{mg} / \mathrm{L}$ de benzeno e $0,3 \mathrm{mg} / \mathrm{L}$ para xilenos. Portanto, caso o objetivo do lançamento do efluente vise a questão da potabilidade da água, o pós- tratamento (adsorção com carvão ativado, stripping, ou tratamento utilizando ozônio, peróxido de hidrogênio, hipoclorito de sódio), é mais uma vez, recomendado, como alternativa para a remoção não só dos residuais dos BTEX, mas também, para a remoção dos residuais de nitrato e ácido acético gerados nos processos de remoção. No entanto, os resultados obtidos com este reator demonstraram eficiência do biofilme desnitrificante em remover a matéria orgânica (principalmente etanol), o nitrato e os compostos de BTEX, no RAHLF, mesmo quando operado por período extremamente curto (15 dias), indicando elevada adaptação destas células.

A remoção de cada composto de BTEX, separadamente, demonstrou que a degradação de um hidrocarboneto específico não foi dependente da presença de outro hidrocarboneto. Alguns estudos sugerem que a degradação de $o$-xileno ocorre somente em presença de tolueno (Ball e Reinhard, 1996; Kao e Borden, 1997; Phelps e Young, 1999). No presente trabalho, $o$-xileno foi removido independentemente da presença de tolueno. Estes resultados confirmam que o co-metabolismo não foi um fator limitante para que a degradação destes compostos ocorresse, independentemente. No entanto, a eficiência de remoção do $o$-xileno foi inferior quando comparada aos seus isômeros, $p$ xileno e $m$-xileno, mostrando a maior dificuldade do biofilme em promover a remoção.

\subsection{Comparação entre os reatores RAHLF1 e RAHLF2}

A Tabela 23 apresenta uma comparação das eficiências de remoção dos hidrocarbonetos, obtidas nas diferentes condições de alimentações as quais os reatores RAHLF1 e RAHLF2 foram submetidos.

Independentemente da estratégia adotada para operar os reatores, as eficiências de remoção dos hidrocarbonetos obtidas, foram semelhantes para estes dois reatores. Esta semelhança demonstra que, o tempo requerido para que o reator entrasse em estado de equilíbrio, e o biofilme se adaptasse a nova condição, não foi fator limitante para o processo de remoção de hidrocarboneto. Nota-se que, mesmo quando o período operacional dos reatores foi em torno de 15 dias, elevadas eficiências de remoção para 
os hidrocarbonetos já podiam ser observadas. Como mencionado anteriormente, a capacidade em remover os BTEX, em período de operação tão baixo foi, principalmente, associado à adaptação prévia das células ao hidrocarboneto, durante as fases de purificação, isolamento e manutenção da cultura, tornando as células altamente adaptadas à presença dos hidrocarbonetos, além da adsorção na espuma de poliuretano.

Esta adaptação foi também importante, para que o biofilme do RAHLF2, atingisse eficiência de remoção dos hidrocarbonetos, mesmo quando o meio suporte foi substituído, e outro hidrocarboneto foi utilizado para alimentar o reator. Este resultado demonstra que a cultura utilizada como inóculo para formar o biofilme, quando imobilizada em reator anaeróbio horizontal de leito fixo, e submetida às mesmas condições determinadas neste estudo, é capaz de remover benzeno, tolueno, etilbenzeno e xilenos, separadamente, ou quando estes compostos se encontrarem juntos, mesmo em períodos reduzidos de operação do reator.

Tabela 23 - Eficiências de remoção dos hidrocarbonetos obtidas para os reatores.

\begin{tabular}{cccc}
\hline $\begin{array}{c}\text { Hidrocarboneto } \\
\text { (mg/L) }\end{array}$ & $\begin{array}{c}\text { \% Remoção de } \\
\text { hidrocarboneto } \\
\text { (RAHLF1) }\end{array}$ & $\begin{array}{c}\text { \% Remoção de } \\
\text { hidrrocarboneto } \\
\text { (RAHLF2) }\end{array}$ & $\begin{array}{c}\text { Tempo de operação } \\
\text { (dia) }\end{array}$ \\
\hline Benzeno 13,8 & 93,5 & & 24 \\
Benzeno 15,4 & 99,3 & & 50 \\
Benzeno 26,5 & 98,5 & & 28 \\
Benzeno 15,1 & & 89,4 & 18 \\
Benzeno 41,4 & & 89,4 & 17 \\
Tolueno 7,6 & & 98,7 & 34 \\
Tolueno 27,8 & 99,6 & 98,9 & 17 \\
Tolueno 30,8 & & & 42 \\
Etilbenzeno 13,1 & & 99,4 & 42 \\
Etilbenzeno 15,1 & & 99,3 & 48 \\
Etilbenzeno 31,1 & & 99,4 & 28 \\
Etilbenzeno 33,3 & 98,8 & & 15 \\
m-xileno 9,5 & & 94,6 & 13 \\
$m$-xileno 28,4 & & 98,9 & 15 \\
$m$-xileno 32,1 & 99,7 & & 15 \\
$o$-xileno 28,5 & & 93,7 & 15 \\
p-xileno 32,1 & & 99,7 & 15 \\
BTEX 26,5 & 98,8 & & \\
BTEX 32,9 & & & \\
\hline
\end{tabular}


Em relação à eficiência média de remoção da matéria orgânica $\left(\mathrm{DQO}_{\mathrm{f}}\right)$ e de nitrato $\left(\mathrm{N}^{-\mathrm{NO}_{3}}{ }^{-}\right)$, observou-se que houve leve tendência de melhores eficiências destes parâmetros, quando o reator foi operado por mais tempo (Tabela 24).

Tabela 24 - Eficiências de remoção da matéria orgânica $\left(\mathrm{DQO}_{\mathrm{f}}\right)$ e nitrato $\left(\mathrm{N}-\mathrm{NO}_{3}{ }^{-}\right)$obtidas em diferentes condições de alimentação dos reatores.

\begin{tabular}{ccccccc}
\hline $\begin{array}{c}\text { Condição de } \\
\text { Alimentação }\end{array}$ & \multicolumn{2}{c}{$\begin{array}{c}\text { \% média de Remoção } \\
\text { DQO }_{\mathrm{f}}\end{array}$} & \multicolumn{2}{c}{$\begin{array}{c}\text { \% média de Remoção } \\
\text { N-NO}^{-}\end{array}$} & \multicolumn{2}{c}{$\begin{array}{c}\text { Tempo de operação } \\
\text { (dias) }\end{array}$} \\
& RAHLF1 & RAHLF2 & RAHLF1 & RAHLF2 & RAHLF1 & RAHLF2 \\
\hline Benzeno & 91,1 & 89,5 & 87,9 & 98,7 & 102 & 35 \\
Tolueno & 97,3 & 81,5 & 90,5 & 88,6 & 42 & 51 \\
$m$-xileno & 90,4 & 84,7 & 98,9 & 97,0 & 15 & 28 \\
Etilbenzeno & 81,5 & 92,7 & 99,2 & 89,0 & 15 & 118 \\
BTEX & 72,7 & 89,7 & 99,1 & 85,2 & 15 & 15 \\
$o$-xileno & - & 87,0 & - & 97,8 & - & 15 \\
$p$-xileno & - & 87,4 & - & 94,5 & - & 15
\end{tabular}

Salienta-se, que com este reduzido tempo de operação, os reatores produziram efluentes contendo elevadas concentrações de ácido acético. Por este motivo, sugere-se que o efluente proveniente de um reator operado nestas condições, passe por um sistema de pós-tratamento, para que haja remoção, não só do excedente de ácido acético e nitrato, assim como, dos residuais dos compostos BTEX, também presentes neste efluente.

\subsection{Análises complementares}

\subsection{1 - Avaliação da formação de amônia ao longo do reator}

Para confirmar que a redução desassimilativa de nitrato a amônia não estava ocorrendo nos reatores, foram realizadas análises para detectar a presença de $\mathrm{N}_{-} \mathrm{NH}_{4}{ }^{+}$, ao longo dos sistemas (Tabela 25). A presença de baixas concentrações de amônia somente no afluente demonstrou, mais uma vez, que as culturas isoladas não realizaram o metabolismo de redução desassimilativa de nitrato a amônia e sim, a desnitrificação. Os valores das concentrações medidas neste ensaio estão apresentados no Apêndice J. 
Tabela 25 - Concentração de amônia afluente e efluente do RAHLF1 e RAHLF2

\begin{tabular}{ccc}
\hline Pontos de & RAHLF1 & RAHLF2 \\
amostragem & Concentração N-NH ${ }^{+}(\mathrm{mg} / \mathrm{L})$ & Concentração N-NH ${ }_{4}^{+}(\mathrm{mg} / \mathrm{L})$ \\
\hline Afluente & 7,27 & 6,96 \\
L/D 4 & - & - \\
L/D 8 & - & - \\
L/D 12 & - & - \\
L/D 16 & - & - \\
L/D 20 & - & - \\
Efluente & - & - \\
\hline
\end{tabular}

(-) Valores abaixo do limite de detecção do método.

\subsubsection{Avaliação da adsorção de BTEX}

A capacidade de adsorção dos compostos de BTEX pelo meio suporte (espuma de poliuretano) e biopartícula (biomassa aderida na espuma) foi avaliada no estudo realizado por Nardi (2002), com a finalidade de se verificar a influência da adsorção na remoção destes hidrocarbonetos. De acordo com a autora, a capacidade de adsorção dos compostos de BTEX pela espuma foi o dobro em relação à adsorção observada para a biopartícula, no entanto, a autora concluiu que a adsorção era pouco significativa quando comparada à quantidade total de BTEX que era removido pelo sistema.

Baseando-se nos dados de adsorção relatados por Nardi (2002), a quantificação da adsorção dos hidrocarbonetos, no meio suporte e na biopartícula, foi estimada para os compostos utilizados nos do presente estudo. Os cálculos realizados para esta estimativa estão disponíveis no Apêndice K. Os resultados relativos à adsorção (Tabela 26) demonstraram que em todas as condições de alimentação as quais os reatores foram submetidos, a adsorção dos hidrocarbonetos, no meio suporte e biopartícula, foi bastante inferior, quando comparada à quantidade de BTEX removida nos sistemas (Tabela 26). Este resultado indica que a remoção foi o principal processo ocorrido no reator. Esta mesma conclusão também foi relatada por Cattony (2005) no estudo com RAHLF tratando benzeno e tolueno, sob condições sulfetogênicas. 
Tabela 26 - Avaliação da capacidade de remoção dos compostos de BTEX pelo sistema levando-se em consideração a adsorção dos hidrocarbonetos na espuma e na biopartícula.

\begin{tabular}{ccccc}
\hline Reator & $\begin{array}{c}\text { Tóxico } \\
\text { avaliado }\end{array}$ & $\begin{array}{c}\text { Total de tóxico que } \\
\text { passou no sistema }(\mathbf{m g})\end{array}$ & $\begin{array}{c}\text { Adsorção na espuma e na } \\
\text { biopartícula }(\mathbf{m g})\end{array}$ & $\begin{array}{c}\text { Remoção de tóxico } \\
(\mathbf{m g})\end{array}$ \\
\hline RAHLF1 & Benzeno & 2989,2 & 53,29 & 2935,91 \\
RAHLF1 & Tolueno & 2166,19 & 81,93 & 2084,26 \\
RAHLF1 & Etilbenzeno & 829,08 & 113,05 & 716,03 \\
RAHLF1 & $m$-xileno & 806,4 & 108,92 & 697,48 \\
& & & & \\
RAHLF2 & Benzeno & 1464,96 & 53,29 & 1411,67 \\
RAHLF2 & Tolueno & 1213,8 & 81,93 & 1131,87 \\
RAHLF2 & Etilbenzeno & 3581,83 & 113,05 & 3468,78 \\
RAHLF2 & $o$-xileno & 660,24 & 108,92 & 551,32 \\
RAHLF2 & $m$-xileno & 903,59 & 108,92 & 794,67 \\
RAHLF2 & $p$-xileno & 806,4 & 108,92 & 697,48 \\
\hline
\end{tabular}

\subsection{3 - Avaliação da concentração de BTX na saída de gás}

Além da adsorção, deve-se ainda considerar a perda de BTEX através da saída de gás do reator. No estudo de Fernandes (2005), com reatores RALHF, imobilizado com lodo de abatedouro de aves, tratando compostos de BTEX, a autora relatou a ocorrência de perda destes hidrocarbonetos, através do arraste dos gases formados durante o processo da biodegradação. Neste estudo, concluiu-se que o tempo de detenção hidráulica (TDH) aplicado no sistema e a produção de gás foram fatores determinantes destas perdas, sendo que, quanto maior fosse o TDH, maiores perdas eram observadas. Assim, para TDH de 16 horas e produção de metano de 586 $\mathrm{mmol} / \mathrm{TDH}$, a autora relatou que as perdas de benzeno, tolueno e $m$-xileno foram estimadas em 0,28 mg/L, 0,36 mg/L e 0,16 mg/L, respectivamente.

Conclui-se, portanto, que embora tenham ocorrido perdas dos hidrocarbonetos através da adsorção no meio suporte e biopartícula e, possivelmente, pelo arraste dos gases, produzidos no processo de biodegradação, a remoção de BTEX observada no presente estudo ocorreu, principalmente, pelo processo de biodegradação. 


\section{EXAME MICROSCÓPICO DOS REATORES}

O acompanhamento microscópico das amostras mostrou que os biofilmes dos reatores foram predominantemente colonizados por bacilos e cocos. (Figura 46). Estas morfologias foram observadas em todas as condições de alimentação as quais os reatores foram submetidos.

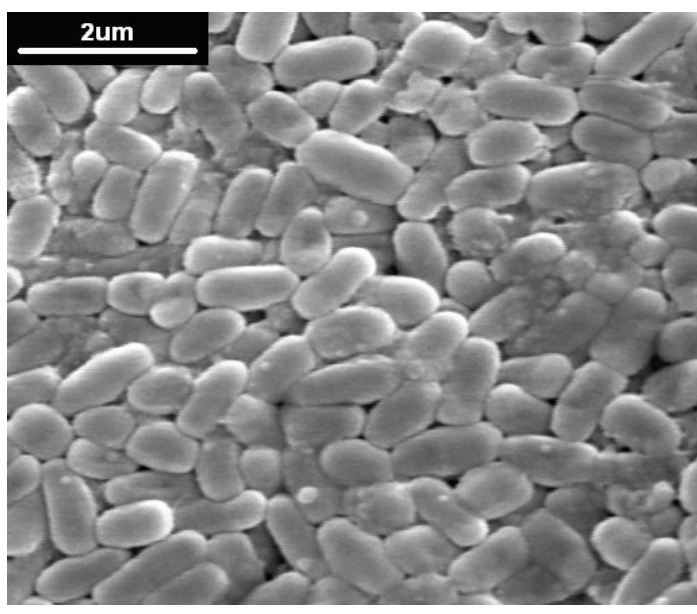

(a)

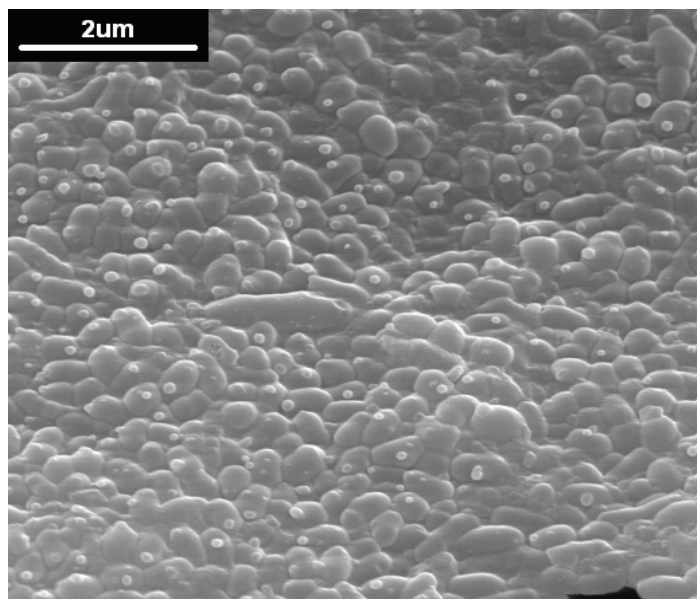

(b)

Figura 46 - Microscopia de varredura (5000X) mostrando morfologias predominantes observadas nos biofilmes dos reatores RAHLF1 e RAHLF2: (a) bacilos e (b) cocos.

A presença constante de cordões celulares de bacilos, assim como de cocos, foi observada, especialmente, nos primeiros seguimentos dos reatores (L/D 4 e L/D 8), onde a concentração da matéria orgânica foi maior. Este arranjo celular foi associado às condições adversas do meio, o que fez com que as células se agrupassem (Figura 47). 


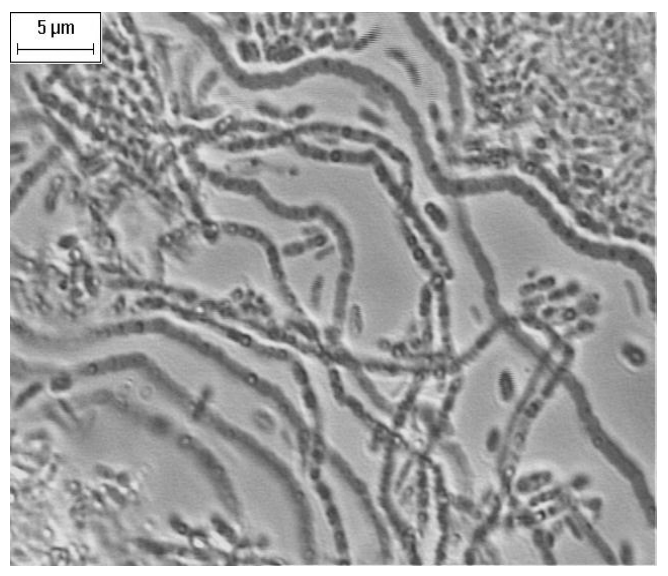

(a)

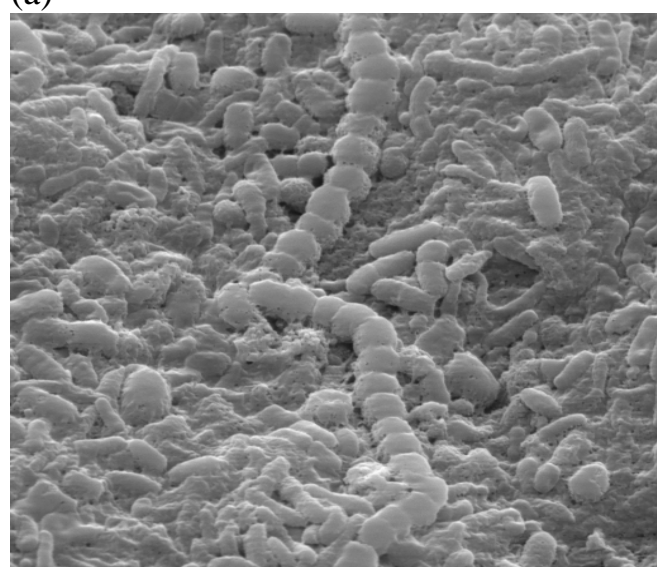

(c)

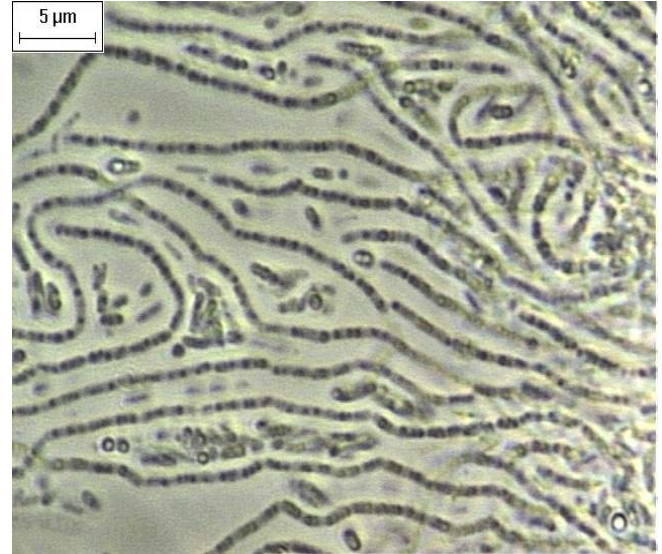

(b)

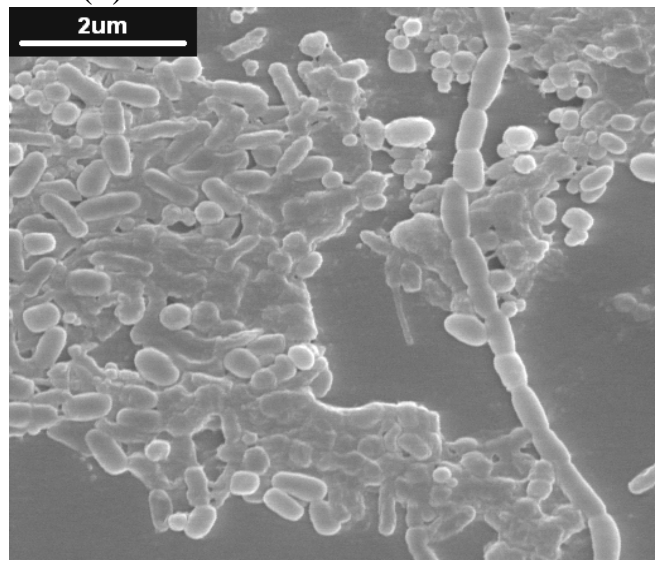

(d)

Figura 47 - Microscopia de contraste de fase (1500X) e eletrônica de varredura (5000X) mostrando os cordões celulares observados nas amostras obtidas dos reatores RAHLF1 e RAHLF2, em diferentes condições de alimentação: (a) RAHLF1 alimentado com BTEX, (b) RAHLF1 alimentado com tolueno, (c) RAHLF2 alimentado com benzeno e (d) RAHLF1 alimentado com etilbenzeno.

Outra morfologia freqüentemente observada nos biofilmes foi bacilos mais alongados destacados na Figura 48.

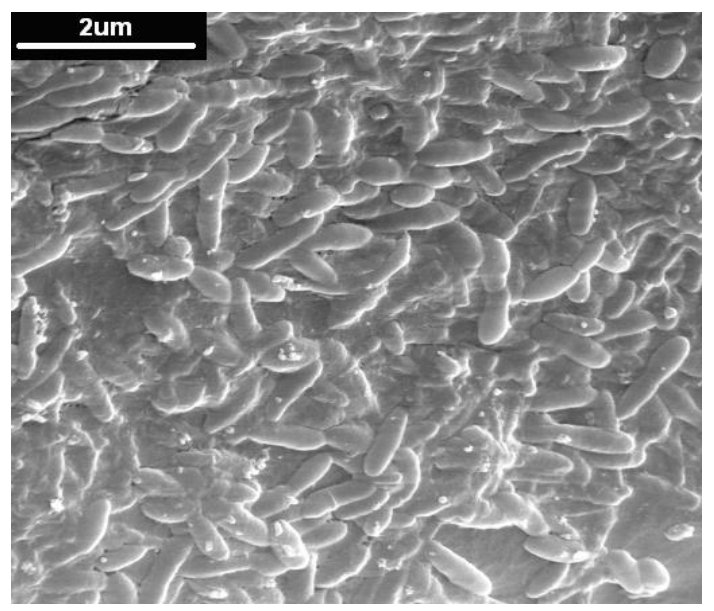

Figura 48 - Microscopia de eletrônica de varredura (5000X) de bacilos em amostra do reator RAHLF2 alimentado com benzeno (L/D 4). 
Embora pouco freqüentes protozoários foram observados em alguns pontos do reator (Figura 49). Estes microrganismos podem ter se favorecido da presença do etanol, presente no substrato de alimentação do reator.

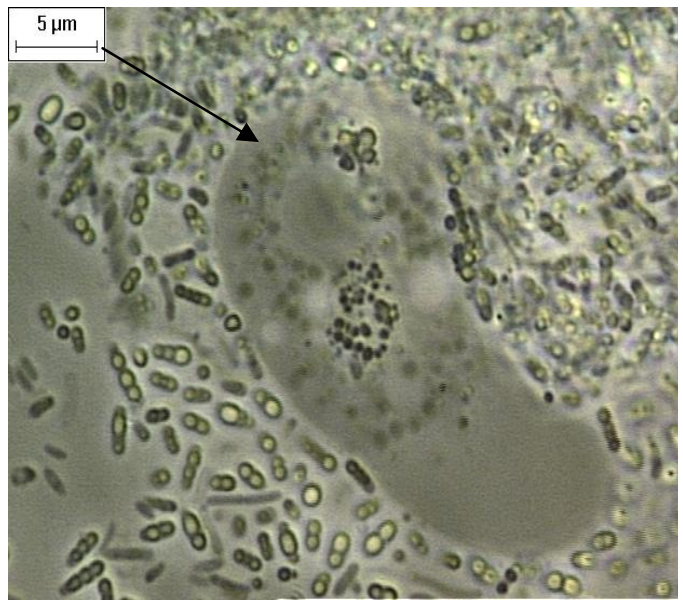

(a)

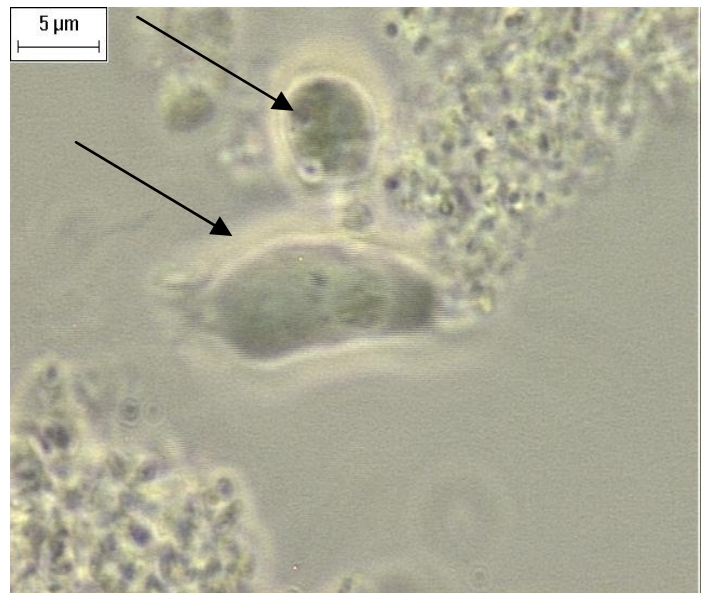

(b)

Figura 49 - Microscopia de contrate de fase (1500X). Protozoário observado no L/D $=8$ do reator RAHLF2 alimentado com tolueno (a), e no reator RAHLF1 alimentado com benzeno (b).

Cistos foram freqüentemente observados, nos locais onde o crescimento celular era intenso (L/D 4 e 8) (Figura 50).

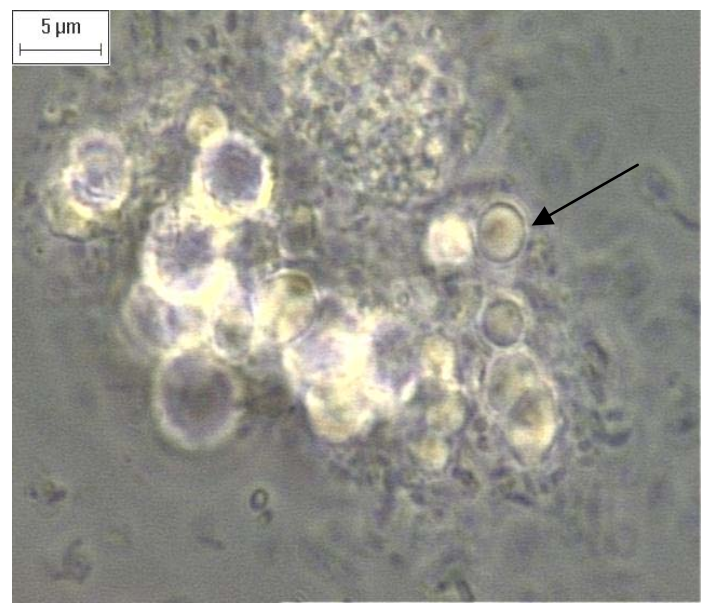

(a)

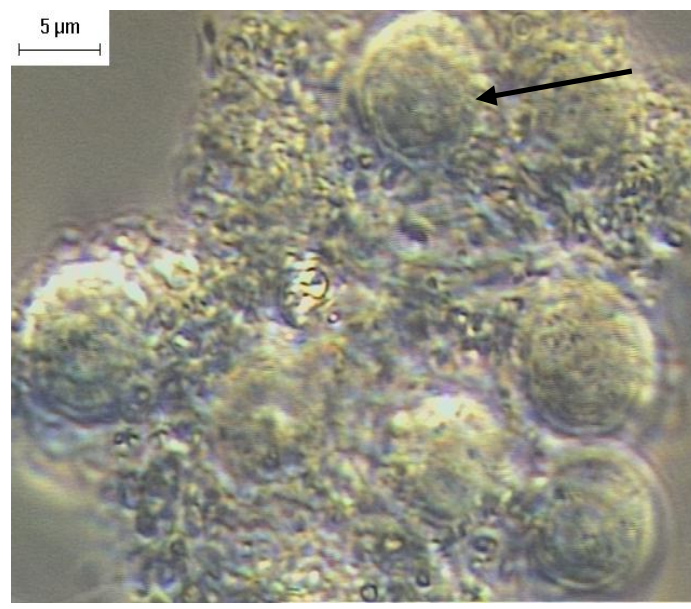

(b)

Figura 50 - Microscopia de contraste de fase (1500X).Cistos observados no L/D 4 do reator RAHLF1 alimentado com $m$-xileno (a) e do reator RAHLF2 alimentado com benzeno (b).

Suspeitando-se de que a anaerobiose tivesse se estabelecido em microambientes na espuma de poliuretano devido, principalmente, ao crescimento celular denso e à formação de polímeros, procedeu-se ao exame de microscopia de fluorescência para avaliar a possibilidade da presença de arquéias metanogênicas. Nenhuma fluorescência foi registrada nas microscopias realizadas, assim como, também não se verificou nenhuma produção de metano, nas amostras coletadas para a análise deste gás. 
Especialmente durante a alimentação do RAHLF1 com BTEX, uma morfologia bem diferenciada foi observada nas amostras obtidas do último seguimento do reator (L/D20). Neste ponto de amostragem, aglomerados de bacilos, com aspecto de cultura pura, foram constantemente observados (Figura 51a). Células semelhantes foram observadas durante a caracterização nutricional da cultura, quando a mesma foi avaliada quanto a capacidade de crescer utilizando etanol como fonte de carbono, sob condições fermentativas (Figura 51b). Assim, é possível que os microrganismos observados no biofilme, cresceram como resultado da fermentação do etanol, presente neste segmento do reator. De fato, neste ponto de amostragem (L/D 20), durante a alimentação com BTEX, o nitrato já havia sido totalmente consumido e ácido acético foi detectado na concentração de $571,5 \mathrm{mg} / \mathrm{L}$.

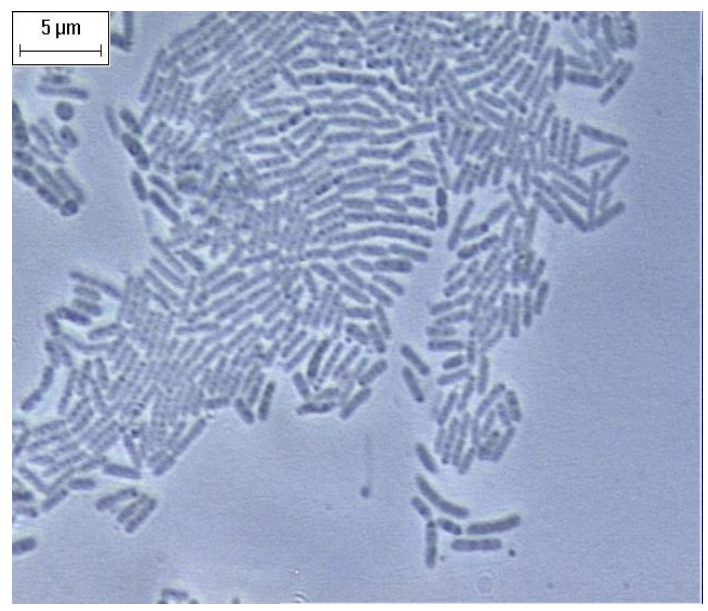

(a)

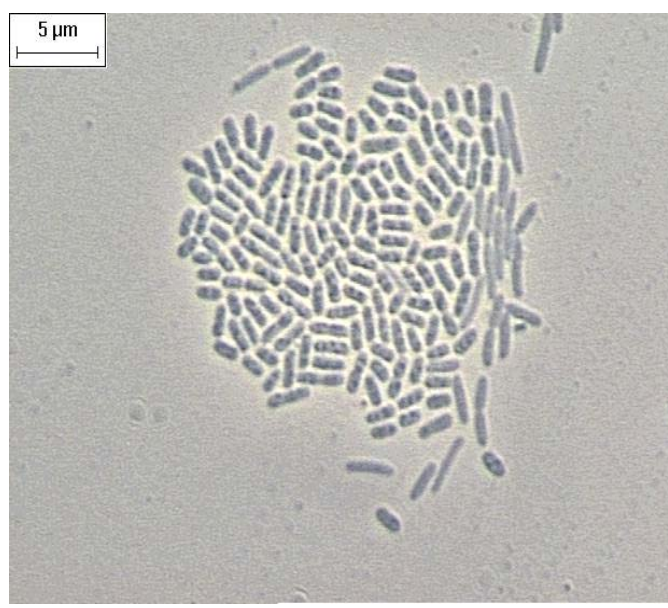

(b)

Figura 51 - Microscopia óptica de contraste de fase (1500X) de bacilos observados em (a) biofilme do RAHLF1 alimentado com BTEX (L/D 20) e (b) crescimento em presença de etanol, observado no ensaio de caracterização nutricional, sob condições fermentativas. 


\section{ANÁLISE MOLECULAR}

As análises realizadas pela metodologia da eletroforese em gel com gradiente desnaturante (DGGE) foram feitas para verificar a possível mudança da comunidade ao longo do reator, ou em conseqüência das alimentações com os diferentes hidrocarbonetos. Amostras obtidas ao final das alimentações com benzeno (RAHLF1) e etilbenzeno (RAHLF2), nos pontos de amostragens L/D 4, L/D 8, L/D 12, L/D 16 e L/D 20 dos reatores foram submetidas à analise por DGGE, para avaliar possíveis modificações da comunidade ao longo dos reatores (Figura 52). Um mesmo padrão de bandas foi observado para as amostras obtidas ao longo do reator, demonstrando que as comunidades presentes no primeiro seguimento dos reatores se mantiveram em toda sua extensão. Embora um mesmo padrão tenha sido observado ao longo do reator, algumas populações apresentaram flutuações, sendo mais representativas, ou menos representativas, em determinados pontos do reator.

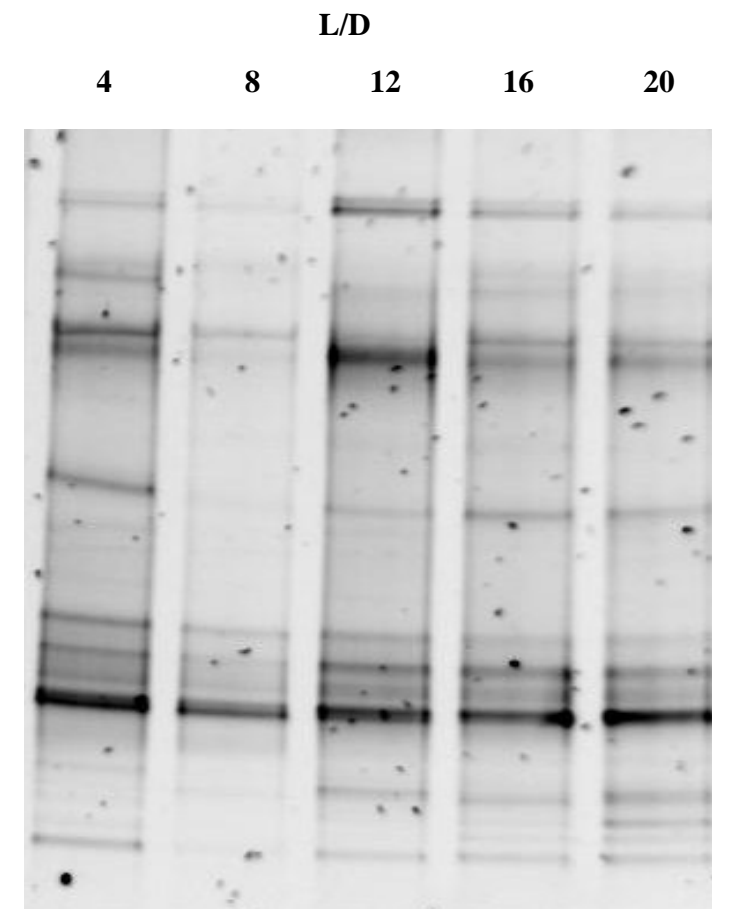

(a)

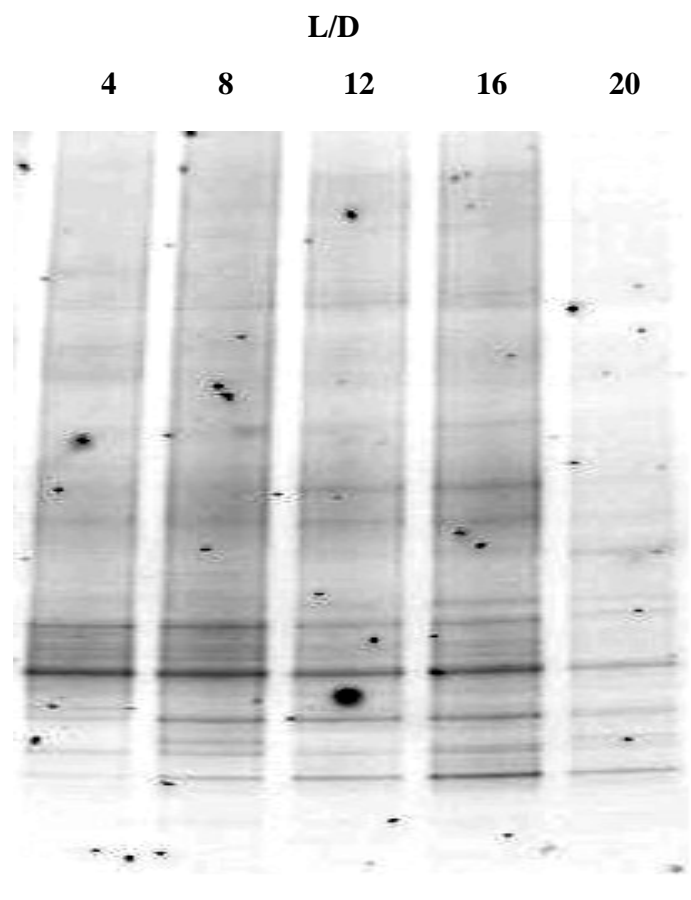

(b)

Figura 52 - Padrão de bandas do DGGE (DNA ribossomal 16S - primer: Nielsen et al., 1999) das amostras obtidas ao longo do reator RAHLF1 alimentados com benzeno (26,5mg/L) (a), e reator RAHLF2 alimentado com etilbenzeno $(31,1 \mathrm{mg} / \mathrm{L})(\mathrm{b})$. Gradiente de desnaturação $40 \%$ a $60 \%$. 
Para verificar se as diferentes condições de alimentação as quais os reatores foram submetidos (benzeno, tolueno, etilbenzeno, xileno e BTEX) provocaram a seleção ou o desenvolvimento de comunidades específicas, amostras do biofilme foram coletadas em cada uma destas condições e avaliadas pelo DGGE. Todas as amostras foram obtidas no primeiro ponto de amostragem ( $\mathrm{L} / \mathrm{D}=4)$. A Figura 53 representa $\mathrm{o}$ DGGE realizado para as diferentes condições de alimentação do reator RAHLF1 (benzeno 26,5 mg/L, tolueno 30,8 mg/L, $m$-xileno 32,1 mg/L, etilbenzeno 33,3 mg/L e BTEX 26,5 mg/L)

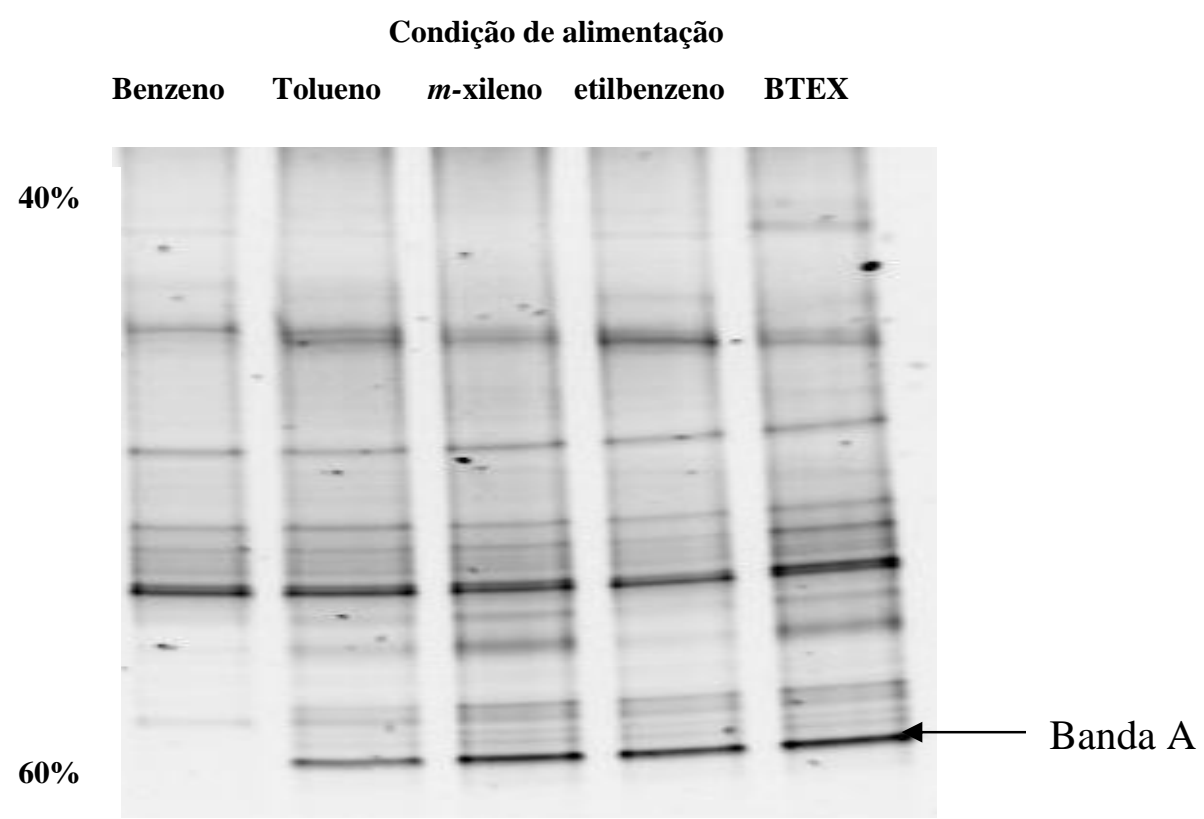

Figura 53 - Padrão de bandas do DGGE (DNA ribossomal 16S - primer: Nielsen et al., 1999) das amostras obtidas no L/D $=4$ em diferentes condições de alimentação do reator RAHLF1.

Nas amostras referentes às alimentações com tolueno, etilbenzeno, $m$-xileno e BTEX, os padrões de bandas produzidos foram bastante semelhantes, com diferenças apenas nas intensidades de determinadas bandas. A presença de uma banda expressiva (banda A), nestas condições de alimentação, demonstra o desenvolvimento de uma população altamente adaptada, capaz de crescer em presença de altas concentrações destes hidrocarbonetos.

Entre as amostras analisadas, o único padrão de bandas diferenciado foi observado para amostra obtida da alimentação com benzeno. A ausência da banda A e outras bandas menos expressivas, somente nesta condição de alimentação, foi relacionada à alta toxicidade do benzeno $(26,5 \mathrm{mg} / \mathrm{L})$, que pode ter sido fator seletivo para estas comunidades. É possível que estas populações estivessem presentes no 
biolfilme, quando o reator estava sendo alimentado com concentrações mais baixas de benzeno (13,8 mg/L e 15,4 mg/L). No entanto, análise de DGGE, nestas condições, não foram realizadas, para que esta observação fosse conclusiva.

A Figura 54 apresenta o DGGE referente às amostras obtidas no L/D 4, nas diferentes condições de alimentação do RAHLF2 (benzeno 41,4 mg/L, tolueno 27,8 $\mathrm{mg} / \mathrm{L}$, etilbenzeno $31,1 \mathrm{mg} / \mathrm{L}, o$-xileno $28,5 \mathrm{mg} / \mathrm{L}, m$-xileno $28,4 \mathrm{mg} / \mathrm{L}, p$-xileno 32,1 mg/L e BTEX 32,9mg/L). Enquanto que no reator RAHLF1 um mesmo padrão de bandas foi observado para as diferentes condições de alimentação, demonstrando a estabilidade da comunidade, no RAHLF2, diferentes padrões de bandas foram observados para as amostras obtidas das diferentes condições alimentação.

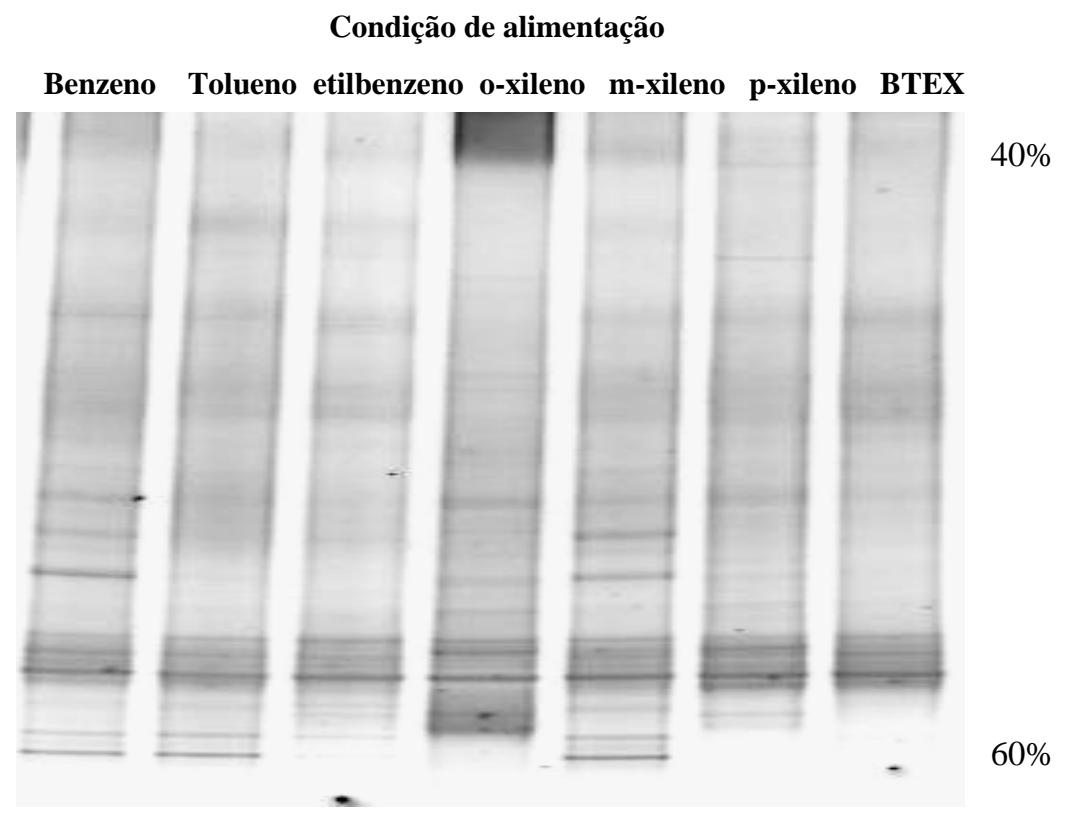

Figura 54 - Padrão de bandas do DGGE (DNA ribossomal 16S - primer: Nielsen et al., 1999) das amostras obtidas do reator RAHLF2, nas diferentes condições de alimentações.

Embora populações diferentes tenham ocorrido nas diferentes condições de alimentação, algumas semelhanças entre determinados padrões de bandas foram observadas. A Figura 55 apresenta o DGGE referente ao reator RAHLF2, de forma mais detalhada. 


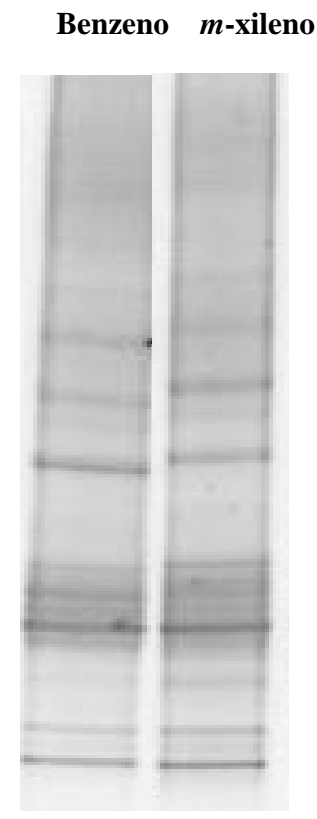

(a)

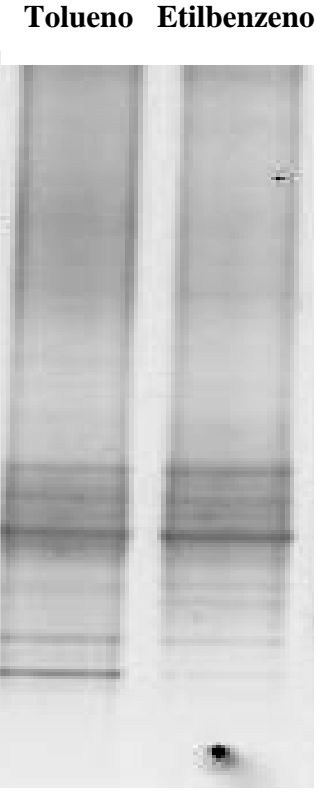

(b)

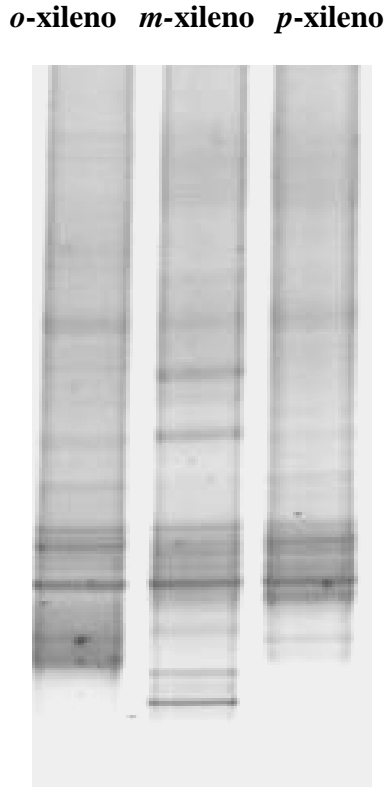

(c)

Figura 55 - Detalhes do DGGE (DNA ribossomal 16S - primer: Nielsen et al., 1999) das amostras obtidas do reator RAHLF2 nas diferentes condições de alimentações: (a) comparação das amostras obtidas da alimentação com benzeno e $m$-xileno, (b) comparação das amostras obtidas da alimentação com tolueno e etilbenzeno, (c) comparação das amostras obtidas da alimentação com $o$-xileno, $m$-xileno e $p$-xileno. Gradiente de concentração do gel (40\% a 60\%)

Padrões de bandas semelhantes foram observados nas amostras referentes às alimentações com benzeno e $m$-xileno (Figura 55a) e, tolueno e etilbenzeno (Figura 55b). Nestas duas últimas condições, observou-se uma diferenciação entre as amostras, apenas em relação à intensidade das bandas.

Esperava-se que um único padrão de bandas fosse obtido para as alimentações com o-xileno, $m$-xileno e $p$-xileno, uma vez que estes compostos são isômeros. No entanto, padrões de bandas diferenciados foram produzidos para as amostras referentes às estas alimentações (Figura 55c).

O padrão de banda observado na amostra referente à alimentação com BTEX apresentou menor número de bandas do que os observados para as outras condições de alimentação (Figura 54). Uma explicação para a menor representatividade populacional nesta condição, seria a alta concentração de BTEX utilizada $(32,9 \mathrm{mg} / \mathrm{L})$ e ao pouco tempo destinado à operação do reator, dificultando a adaptação de determinadas populações a estas condições. 
Conclui-se destas análises que diferentes padrões de bandas foram obtidos para as diferentes condições de alimentação, demonstrando que, embora o inóculo utilizado para colonizar o reator RAHLF2 tenha sido o mesmo para todas condições de alimentações, a presença dos diferentes compostos levou ao desenvolvimento de comunidades específicas para hidrocarbonetos específicos. Portanto, o desenvolvimento de comunidades específicas pode estar relacionado à produção de diferentes intermediários, gerados a partir da degradação de cada um destes compostos, favorecendo o desenvolvimento de diferentes comunidades. Deve-se considerar também que, a remoção do meio suporte, juntamente com os baixos períodos de operação com os hidrocarbonetos, pode ter dificultado a formação de comunidades estáveis no biofilme. Neste ponto de vista, somente as comunidades observadas nas alimentações com etilbenzeno e tolueno, nas quais o reator foi operado durante 118 dias e 51 dias, respectivamente, representariam comunidades realmente estabilizadas e adaptadas às condições impostas ao reator, enquanto que, nas outras condições, as populações estariam ainda em fase de adaptação, e por isso altas flutuações destas comunidades foram observadas no DGGE.

Os inóculos utilizados para formar os biofilmes nos reatores RAHLF1 e RAHLF2 foram, também, submetidos às análises de DGGE. Os padrões de bandas obtidos para os dois inóculos foram idênticos, mostrando que os biofilmes dos reatores RAHLF1 e RAHLF2 foram formados por uma mesma comunidade de microrganismos (Figura 56). Pelo menos 5 bandas foram observadas para a amostra dos inóculos, sendo 2 destas bandas mais expressivas (banda B e Banda C). Possivelmente, estas duas bandas estejam relacionadas às duas morfologias predominantes observadas nos exames microscópicos (bacilos e cocos).

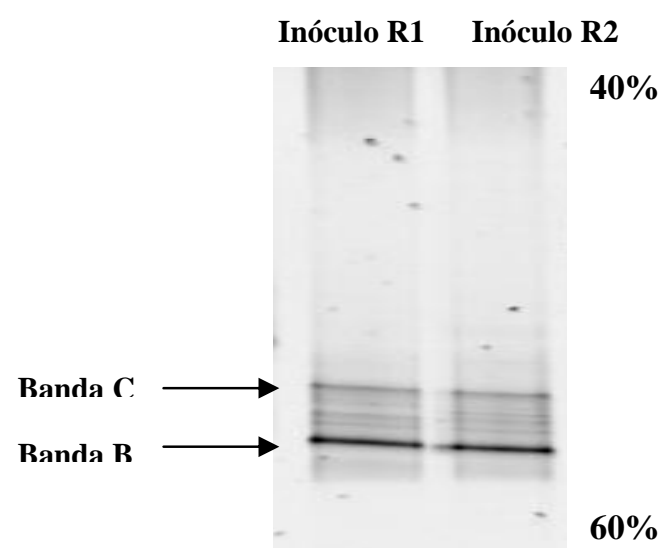

Figura 56 - DGGE (DNA ribossomal 16S - primer: Nielsen et al., 1999) mostrando os padrões de bandas obtidos a partir das amostras dos inóculos dos reatores RAHLF1 e RAHLF2 
A Figura 57 apresenta o DGGE das amostras dos inóculos, juntamente com as amostras obtidas dos biofilmes dos reatores. Comparando-se os padrões de bandas obtidos das amostras dos inóculos com aqueles obtidos dos biofilmes (demarcado com um retângulo), observou-se que, embora a comunidade original presente no inóculo tenha permanecido no biofilme, outras comunidades estiveram presentes somente no interior do reator. É possível que as condições em que o inóculo foi desenvolvido, (crescimento planctônico, em atmosfera desnitrificante) não tenha sido favorável ao desenvolvimento de determinadas comunidades, que vieram a se desenvolver somente no interior do reator. No entanto, pode-se considerar que estas populações sejam organismos contaminantes, uma vez que no RAHLF fica impossível se manter as condições estéreis. As análises de DGGE realizadas para as amostras obtidas dos reatores RAHLF1 e RAHLF2 demonstraram que as comunidades presentes no RAHLF1 mostraram-se bastante estáveis, permanecendo, praticamente, as mesmas, em todas as condições de alimentação as quais o reator foi submetido. De forma contrária, diferentes comunidades foram observadas, para as diferentes condições de alimentação do reator RAHLF2, mostrando a instabilidade destas populações.
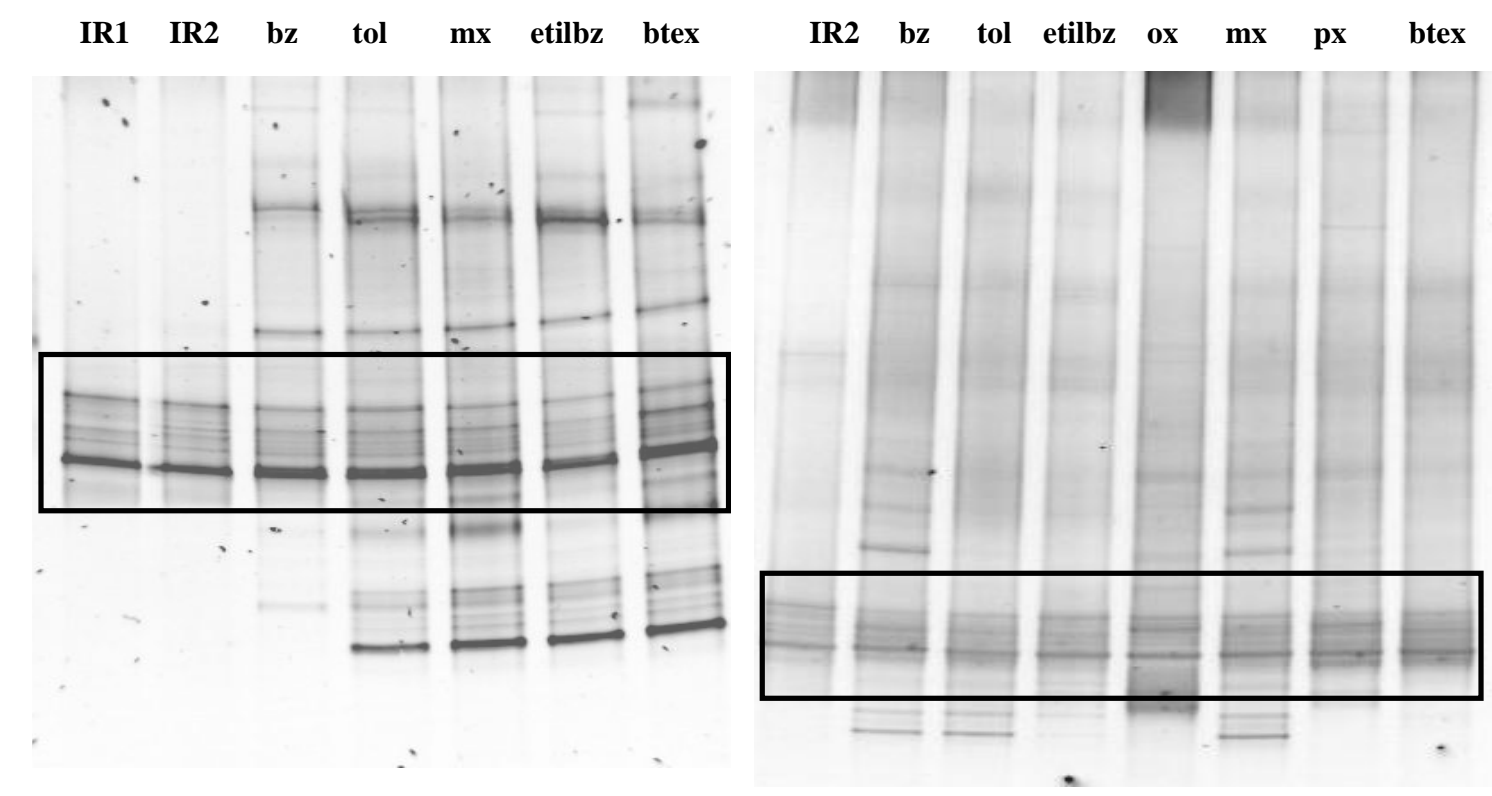

Figura 57- DGGE (DNA ribossomal 16S - primer: Nielsen et al., 1999) das amostras obtidas em diferentes condições de alimentação dos reatores RAHLF1 (a) e RAHLF2 (b). IR1= amostra do inóculo utilizado para formar o biofilme do RAHLF1. IR2 = amostra do inóculo utilizado para formar o biofilme do RAHLF2. Bz - alimentação com benzeno, Tol - alimentação com tolueno, ox - alimentação com oxileno. mx - alimentação com $m$-xileno. px - alimentação com p-xileno. etilbz - alimentação com etilbenzeno, btex - alimentação com BTEX. O retângulo destaca o padrão de bandas observado tanto no inóculo, como no biofilme. Gradiente de desnaturação do gel $40 \%$ a $60 \%$. 


\subsection{Sequenciamento}

Com o objetivo de se obter mais informações sobre quais eram as principais populações presentes nas amostras dos inóculos e dos biofilmes, procedeu-se o sequenciamento das amostras utilizando-se o primer descrito por So e Young (1999). O predomínio de espécies do gênero Paracoccus foi observado em todas as amostras sequienciadas. Para as amostras obtidas do biofilme do reator RAHLF2, alimentado com etilbenzeno, dos 80 clones seqüenciados, 77 clones apresentaram seqüências descritas para espécies do gênero Paracoccus. Os outros três clones apresentaram associação parcial com as sequiências de Variovorax sp., Pseudomonas stutzeri e Xanthomonas sp.

Nas amostras obtidas do RAHLF1, alimentado com benzeno, foram sequienciados 33 clones, dos quais 23 seqüências apresentaram similaridade com o gênero Paracoccus e dez seqüências apresentaram similaridade com bactérias não cultiváveis. No sequenciamento referente aos inóculos, todos os clones seqüenciados (16 clones do inóculo do RAHLF1 e 22 clones do RAHLF2) apresentaram sequiências que foram associadas ao gênero Paracoccus.

O primer (So e Young, 1999) utilizado no sequenciamento foi escolhido por ser específico e capaz de gerar seqüências de DNA grande o suficiente (880pb) para serem comparadas com o banco eletrônico de dados NCBI BLAST. No entanto, a diversidade de populações observada no DGGE não foi refletida no sequenciamento, ou seja, o sequenciamento apontava o predomínio de apenas um grupo de microrganismos (Paracoccus) nas amostras. Suspeitando-se que a complexidade da microbiana tanto dos inóculos, quanto dos biofilmes, pudesse ser mais complexa do que o resultado do sequenciamento apontava, avaliou-se a necessidade de utilizar um segundo primer (Muyzer, et al., 1993) para confirmar os resultados obtidos.

A Figura 58 apresenta o DGGE das amostras referentes ao reator RAHLF1, gerado a partir da utilização do primer descrito por Muyzer et al. (1993). Para se conhecer quais eram os grupos de microrganismos mais representativos no DGGE, as bandas mais expressivas foram recortadas do gel e, posteriormente, seqüenciadas. 


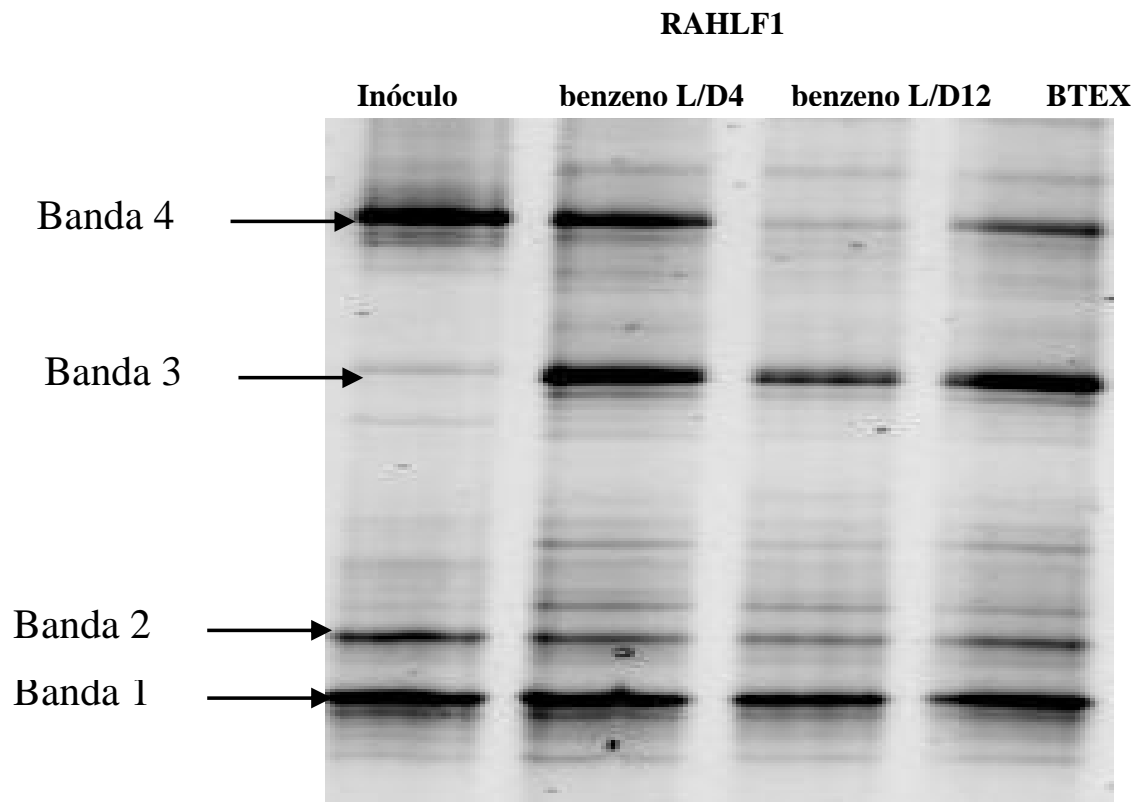

Figura 58 - DGGE (DNA ribossomal 16S - Muyzer et al 1993) das amostras obtidas do RAHLF1. As setas indicam as bandas que foram recortadas e sequienciadas.

Os resultados dos sequenciamentos revelaram a presença de uma comunidade microbiana formada por espécies do gênero Paracoccus (bandas 1 e 2), Bacteroides (banda 3) e Pseudomonas (banda 4).

O gênero Paracoccus é membro de uma parte do subgrupo $\alpha$-Proteobacteria conhecido como grupo Rhodobacter. Atualmente, abrange 17 espécies que são encontradas em diferentes ambientes (Bartosik et al., 2002).

Morfologicamente, todas as espécies são cocoides apresentando de 0,4 a 0,9 $\mu \mathrm{m}$ de diâmetro, ou cocobacilos com até 2,0 $\mu \mathrm{m}$ de comprimento, e ocorrem como células únicas, pares ou em aglomerados. Todas espécies são Gram-negativas e a maioria não apresentam motilidade. Todas as espécies crescem aerobicamente numa variedade ampla de substratos orgânicos e algumas são capazes de crescimento anaeróbio com nitrato ou óxido nitroso como aceptor de elétrons, gerando nitrogênio gasoso como produto final. Nenhuma espécie de Paracoccus apresenta capacidade de crescer fermentativamente e a maioria pode acumular poli-hidroxibutirato sob condições de crescimento onde haja suficiente fonte de carbono.

Algumas dessas espécies, incluindo Paracoccus alcaliphilus, Paracoccus carotinifaciens, Paracoccus aminophilus, e Paracoccus kondratievae, foram isoladas do solo. Outras espécies foram isoladas de ambientes contendo variedade de compostos tóxicos; Paracoccus methylutens foi isolado de lençol freático contaminado com diclorometano (Doronina et al., 1998); Paracoccus pantotrophus foi isolado de reator 
de leito fluidificado desnitrificante (Roberston e Kuenen, 1983); Paracoccus alkenifer foi isolado de biofiltro usado no tratamento de resíduos gasosos de criação (Lipski et al., 1998) e Paracoccus kocurii foi isolado de água residuária industria de semicondutor (Ohara et al., 1990). Algumas espécies de Paracoccus denitrificans, que foi a primeira espécie do gênero Paracoccus isolada, também tem sido encontrada em diferentes habitats, incluindo esgoto, lodo, solo e estrume de cavalo e de vaca. Duas espécies ( $P$. seriniphilus e P. zeaxanthinifaciens) foram isoladas, recentemente, de ambiente marinho (Pukall et al., 2003). As bactérias do gênero Paracoccus estão entre os microrganismos mais metabolicamente versáteis. Estes organismos são quimiorganotróficos (utilizando ampla variedade de compostos orgânicos, incluindo aqueles potencialmente poluentes, como acetona) ou facultativos quimiolitoautotróficos (utilizando compostos reduzidos de enxofre, tais como sulfeto, tiossulfato, tiocianato, ou hidrogênio molecular, como fonte de energia). A utilização de compostos como formiato, metanol, trimetilamina, tetrametilamonia é frequientemente observada em condições anaeróbias (respiração pelo nitrato) (Baj, 2000). Assim, por causa da sua versatilidade metabólica, as espécies do gênero Paracoccus têm importante papel no ciclo de elementos no ambiente.

Parece que todas estas características fisiológicas sugerem a possibilidade do gênero Paracoccus ser utilizado em sistemas de biorremediação, particularmente porque muitas espécies podem utilizar nitrato como aceptor de elétrons. Uma dessas espécies é Paracoccus solventivorans, isolada em área de uma companhia de gás natural, que demonstrou capacidade de degradar acetona e reduzindo nitrato (Siller et al., 1996).

Além da versatilidade metabólica descrita anteriormente, deve-se destacar, também, a presença de megaplasmídio (Bartosik et al., 2002). Megaplasmídios são um grupo de plasmídios variando em tamanho de 100 a $1700 \mathrm{~kb}$, que podem ser encontrados em microrganismos da subdivisão $\alpha$ Proteobacteria. Estes megaplasmídios carregarem genes envolvidos em diversas vias catabólicas, determinando o potencial de biorremediação de seus hospedeiros. No trabalho de Bartosik et al. (2002), o sistema de replicação do megaplasmídio pTAV3 de aproximadamente $400 \mathrm{~kb}$, identificado em Paracoccus versutus, foi caracterizado pelos autores, confirmando o potencial deste microrganismo para degradação de compostos tóxicos.

Espécies do gênero Pseudomonas apresentam função importante na decomposição, biodegradação e ciclos do carbono e nitrogênio. Membros do gênero Pseudomonas são conhecidos por suas habilidades em degradar centenas de compostos orgânicos diferentes, incluindo inseticidas, pesticidas, herbicidas, plásticos e 
hidrocarbonetos do petróleo. A associação de espécies de Pseudomonas com a biodegradação de hidrocarbonetos aromáticos, como os BTEX, já está bem estabelecida. A biodegradação de benzeno, tolueno etilbenzeno e o-xileno, por cocultura de Pseudomonas putida e Pseudomonas fluorescens, foi verificada em biorreator com leito de fibras (Shim e Yang, 1999). Duas espécies de Pseudomonas redutoras de nitrato (Pseudomonas sp.BS2201, e BS2203) isoladas de solo contaminado por petróleo foram capazes de degradar hidrocarbonetos do petróleo (Grishchenkov et al., 2000). Espécies de Pseudomonas foram, também, objetos de estudos sobre a cinética de crescimento destes microrganismos, em presença de BTEX (Alagappan e Cowan, 2004), interações entre os BTEX (Hamed, et al., 2003), e em estudo sobre a dinâmica da comunidade bacteriana, em presença destes compostos. (Kaplan e Kitts, 2004).

Entre as características básicas de todas espécies de Pseudomonas estão a morfologia de bacilos Gram-negativos que podem ser retos ou moderadamente curvos, podendo ocorrer sozinhos, em pares ou em cadeias, com presença de flagelo polar e ausência de esporos. Membros deste gênero são caracterizados por apresentarem propriedades fisiológicas tais como nutrição quimiorganotrófica, metabolismo respiratório, ausência de fermentação e capacidade de crescer em ampla variedade de substratos orgânicos, com exceção de compostos contendo 1 carbono.

Anteriormente, o gênero Pseudomonas incluía tanto espécies aeróbias estritas quanto as espécies anaeróbias, mas, atualmente, apenas as espécies aeróbias obrigatórias são consideradas componentes legítimas deste grupo. No entanto, funções anaeróbias não são totalmente excluídas e podem ser demonstradas por alguns membros, sob certas condições como é o caso, por exemplo, das espécies Pseudomonas denitrificans e Pseudomonas aeruginosa, capazes de crescer realizando o metabolismo desnitrificante.

Uma das bandas seqüenciadas foi associada ao gênero Bacteroides. Espécies desse gênero se caracterizam como bacilos Gram-negativos, não formadores de esporos e anaeróbios obrigatórios. São organismos sacarolíticos e geram elevados níveis de acetato e succinato como produto final do metabolismo.

Embora a representatividade de Bacteroides sp. tenha sido expressiva no DGGE (Figura 58, banda C) das amostras obtidas do biofilme, apenas uma banda fraca, correspondente a este gênero, foi observada na amostra do inóculo. A baixa representatividade de Bacteroides no inóculo pode estar associada presença de oxigênio durante o cultivo celular. Nesta condição, o excesso de oxigênio foi removido, através da troca da atmosfera gasosa para $\mathrm{N}_{2}$, para deixar o meio com potencial de oxi-redução 
favorável ao crescimento de bactérias desnitrificantes. No entanto, mesmo em presença de baixas concentrações de oxigênio o crescimento de Bacteróides sp. pode ter sido prejudicado, uma vez que estas espécies são anaeróbias obrigatórias. Assim, a atmosfera anóxica, durante o crescimento em suspensão, favoreceu o desenvolvimento das populações desnitrificantes, fazendo com que as populações de Bacteroides fossem inibidas tanto pela condição anóxica, quanto pelo alto crescimento das bactérias desnitrificantes. Por outro lado, no interior do reator, com consumo do aceptor final de elétrons (nitrato), pelas células desnitrificantes, zonas anaeróbias se formam proporcionando condições ótimas para o desenvolvimento de organismos anaeróbios, o que justifica a alta expressão da banda referente a este grupo no DGGE (banda c).

Não há relatos da associação de espécies do gênero Bacteroides com a biodegradação de compostos tóxicos. No entanto, a presença destes microrganismos nas amostras justifica-se, uma vez que, o inóculo utilizado para gerar o biofilme foi proveniente de um abatedouro de aves e, algumas espécies de Bacteroides já foram isoladas do trato intestinal de animais, incluindo uma espécie, denominada Bacteroides ovatus-like, que foi isolada de ceco de galinha (ZHU et al., 2002). Desta forma, estes microrganismos poderiam estar envolvidos, não propriamente, com a utilização dos BTEX, mas com seus subprodutos ou outra fonte orgânica, como o etanol e ácido acético presente no meio. Estes mesmos subprodutos podem ser a fonte orgânica utilizada por outras comunidades observadas no DGGE das amostras (bandas menos expressivas), uma vez que o etanol e ácido acético, podem ser facilmente utilizado, por diversos grupos microbianos. 


\section{CONCLUSÕES}

A principal conclusão deste estudo foi a constatação da remoção de etanol, benzeno, tolueno, etilbenzeno e xilenos, em reator anaeróbio horizontal de leito fixo, com biofilme formado por cultura desnitrificante purificada.

Este estudo permitiu também as seguintes conclusões:

$\checkmark$ O lodo granular de reator UASB, usado no tratamento de água residuária de abatedouro de aves, pode ser utilizado como fonte de inóculo alternativa para bactérias desnitrificantes associadas à degradação de BTEX.

$\checkmark$ O meio de cultivo descrito por Dofing et al, sem a solução redutora, mostrou-se adequado para o desenvolvimento de bactérias desnitrificantes.

$\checkmark$ As culturas purificadas em presença de benzeno e etilbenzeno apresentaram predomínio de células Gram-negativas com morfologia de cocos (diplococos/cocobacilos), com versatilidade metabólica na utilização de diferentes substratos, sob condições desnitrificantes e baixo tempo de geração, à semelhança do observado para outras culturas desnitrificantes degradadoras de BTEX.

$\checkmark$ A cultura desnitrificante purificada demonstrou ser capaz de remover benzeno, tolueno, etilbenzeno e xilenos, em reator anaeróbio horizontal de leito fixo, em todas as condições de alimentação as quais os sistemas foram submetidos.

$\checkmark$ Tanto o reator cujo biofilme foi continuamente submetido aos hidrocarbonetos (manutenção do meio suporte), quanto aquele onde o biofilme foi submetido a apenas um hidrocarboneto específico (retirada do meio suporte) apresentou elevadas eficiências de remoção de BTEX.

$\checkmark$ Os compostos de BTEX foram eficientemente removidos, mesmo em curtos tempos de operação dos reatores (15 dias), indicando a possibilidade da utilização deste sistema, imobilizado com a cultura purificada, e operado nas 
mesmas condições determinadas neste estudo, para a biorremediação rápida de locais contaminados com BTEX. Devido aos residuais de BTEX, ácido acético e nitrato presente no efluente dos reatores operados nestas condições, sugere-se o pós-tratamento do efluente gerado para promover a remoção destes residuais.

$\checkmark$ Os reatores operados por períodos mais longos apresentaram-se mais estáveis e com leve tendência de melhores eficiências de remoção da matéria orgânica (DQO) e nitrato.

Em relação aos limites máximos de BTEX permitidos pelo Ministério da Saúde, conclui-se que:

$\checkmark$ Em nenhuma das condições de alimentação com benzeno, as concentrações residuais no efluente enquadraram-se no limite máximo permitido para este composto.

$\checkmark$ De forma geral tolueno, etilbenzeno e xilenos foram removidos gerando residuais dentro dos limites máximos permitidos para estes compostos, seja no reator RAHLF1 ou RAHLF2.

As análises moleculares permitiram as seguintes conclusões:

$\checkmark$ No reator onde o biofilme foi mantido durante todo o período de operação, a comunidade apresentou-se bastante estável, com manutenção de um mesmo padrão de bandas em todas condições de alimentação as quais o reator foi submetido, exceto durante a alimentação com benzeno, onde determinadas populações foram eliminadas. Este resultado confirma a toxicidade do benzeno para as células.

$\checkmark$ No reator onde o meio suporte foi removido de acordo com a alimentação com hidrocarboneto específico, observou-se que diferentes condições de alimentação produziram diferentes padrões de bandas. $\mathrm{O}$ desenvolvimento de comunidades específicas pode estar relacionado à produção de diferentes intermediários, gerados a partir da degradação de cada um destes compostos, favorecendo o desenvolvimento de diferentes comunidades. Deve-se considerar também que, a remoção do meio suporte, juntamente com os baixos períodos de operação com os hidrocarbonetos, pode ter dificultado a formação de comunidades estáveis no biofilme. 
$\checkmark$ Os padrões de bandas obtidos para as duas culturas utilizadas como inóculos nos reatores foram idênticos, mostrando que uma mesma comunidade de microrganismos formou os biofilmes dos reatores RAHLF1 e RAHLF2.

$\checkmark$ Tanto o biofilme do reator RAHLF1, quanto do reator RAHLF2, apresentou maior diversidade na comunidade microbiana, quando comparada à diversidade da comunidade dos inóculos. Este resultado sugere que as condições oferecidas pelo RAHLF foram mais adequadas ao desenvolvimento destas populações, ou ainda, a possível contaminação no reator, uma vez que neste sistema fica impossível se manter as condições estéreis.

O sequênciamento das amostras revelou que:

$\checkmark$ O biofilme do RAHLF1 apresentou populações predominantes formadas por espécies de Paracoccus, Pseudomonas e Bacteróides.

$\checkmark$ O biofilme do RAHLF2, alimentado com etilbenzeno, foi formado por espécies dos gêneros: Paracoccus, Pseudomonas, Xanthomonas $e$ Variovorax 


\section{9 - SUGESTÕES}

Utilizar a metodologia do carbono marcado para comprovar a biodegradação de benzeno, tolueno, etilbenzeno e xilenos pelas células do biofilme.

Utilizar sistemas de pós-tratamento para remover os residuais dos compostos que não se enquadram nos limites permitidos pelo órgão de controle ambiental

Utilizar os resultados obtidos neste estudo para investigar a cinética de degradação dos BTEX.

Utilizar o RAHLF imobilizado com a cultura purificada, em escala real, visando a remoção de BTEX de locais contaminados por estes compostos.

Utilizar as técnicas de clonagem e sequenciamento para identificação das amostras a nível de espécie.

$\checkmark$ Realizar o sequenciamento das amostras do reator RAHLF2, submetido a alimentação com tolueno, etilbenzeno, e xilenos 


\section{REFERÊNCIAS BIBLIOGRÁFICAS}

ALAGAPPAN, G. and COWAN, R.M. (2004). Effect of temperature and dissolved oxygen on the growth kinetics of Pseudomonas putida F1 growing on benzene and toluene. Chemosphere. v.54, p.1255-1265.

ALVAREZ P. J. J.; VOGEL T. M. (1991). Substrate interactions of benzene, toluene, and para-xylene during microbial degradation by pure cultures and mixed culture aquifer slurries. Applied and environmental Microbiology. v.57, n.10, p.2981-2985.

ANDERS, H. J; KAETZKE, A; KAMPFER, P.; LUDWIG, W. and FUCHS, G. (1995). Taxonomic position of aromatic-degrading denitrifying Pseudomonad strains K 172 and KB 740 and their description as new members of the genera Thauera, as Thauera aromatica sp. Nov., and Azoarcus, as Azoarcus evansii sp. nov., respectively, members of the beta subclass of the Proteobacteria .Internaional. Journal of. Systematic Bacteriology, v.40, p.327-333.

ARAUJO, J.C; TÉRAN F.C; OLIVEIRA, R.A; NOUR, E.A.A; MONTENEGRO, M.A.P; CAMPOS, J.R. and VAZOLLER, R.F. (2003). Comparison of hexamethyldisilazane and critical point drying treatments for SEM analysis of anaerobic biofilms and granular sludge. Journal of electron microscopy. v.52, p.429-433.

BAJ, J. (2000). Taxonomy of the genus Paracoccus. Acta Microbiol. Pol. v.49, p.185200

BALL, H.A; JOHNSON, H.A; REINHARD, M.; SPORMANN, AM. (1996). Initial Reactions in Anaerobic Ethylbenzene Oxidation by a Denitrifying Bacterium, Strain EB1. Journal of Bacteriology. v.178, p. 5755-5761.

BARTOSIK, D.; BAJ, J.; BARTOSIK, A.A. (2002). Characterization of the replicator region of megaplasmid pTAV3 of Paracoccus versutus and seach for plasmid-encoded traits. Microbiology. v.148, p. 871-881.

BICALHO, K.V. (1997). Dissolução de gasolina em presença de água e etanol. Tese (Doutorado) - Faculdade de Engenharia Civil, Pontifícia Universidade Católica do Rio de Janeiro. Rio de Janeiro. 1997 
BOLAÑOS, M. L.; VARESCHE, M.B.A.; ZAIAT, M.; FORESTI, E. (2001). Phenol Degradation in Horizontal-flow Anaerobic Immobilized Biomass (HAIB) Reactor Under Mesophilic Conditions. Water Science Technology, v.44, p.167-174.

BORDEN, R.C.; LEE, M.D.; THOMAS, J.M.; BEDIENT, P.B.; WARD, C.H. and WILSON, J.T. (1986). Transport of dissolved hydrocarbons influenced by oxygen limited biodegradation: Field application. Water Resource Research., v.22. p.19831990

BROWN, C.M. (1988). Nitrate metabolism by aquatic bacteria. In: Methods in aquatic bacteriology. John Wiley \& Sons, Ltda.

BURLAND, S.M. and EDWARDS, E.A. (1999). Anaerobic benzene biodegradation linked to nitrate reduction. Applied and Environmental Microbiology. v. 65, n.2, p. 529-533.

CALLADO, N.H. (2001). Reatores seqüenciais em batelada em sistema anaeróbio / aeróbio tratando esgoto sanitário sintético. 221p. Tese (Doutorado) - Escola de Engenharia de São Carlos, Universidade de São Paulo, São Carlos. 2001.

CAPUANO, R.N. and JOHNSON, M.A. (1996). Geochimical reactions during biodegradation/vapor-extraction remediation of petroleum contamination in the vadoze zone. Ground water. v.34, p.31-40.

CATTONY, E.B.M (2005). Remoção de etanol, benzeno e tolueno em reator anaeróbio horizontal de leito fixo na presença de sulfato. 121p. Tese (Doutorado) - Escola de Engenharia de São Carlos, Universidade de São Paulo, São Carlos. 2005

CATTONY, E.B.M.; CHINALIA, F.A.; ZAIAT, M.; FORESTI, E.; VARESCHE, M.B.A. (2003). Remoção de tolueno em reator anaeróbio de leito fixo na presença de sulfato. In: ANAIS DO III SEMINÁRIO DO PROJETO TEMÁTICO DESENVOLVIMENTO, ANÁLISE, APRIMORAMENTO E OTIMIZAÇÃO DE REATORES ANAERÓBIOS PARA TRATAMENTO DE ÁGUAS RESIDUÁRIAS. 2003, São Carlos, UFSCAR. p.1-10

CHIU, Y.C. and CHUNG, M.S. (2003). Determination of optimal DQO/nitrate ratio for biological denitrification. International Biodeterioration \& Biodegradation. v.51, p. 43-49. 
COATES, J.D.; CHAKRABORTY, R.; LACK, J.G.; O'CONNOR, S.M.; Cole, K.A.; BENDER, K.S. and ACHENBACH, L.A. (2001), Anaerobic benzene oxidation coupled to nitrate reduction in pure culture by two strains of Dechloromonas. Nature. v.411, p.1039-1043.

COHEN, Y. (2001). Biofiltration the treatment of fluids by microorganisms immobilized into the filter bedding material: a mini review. Bioresourse Technology, v.77, p.257-274.

CORSEUIL, H. X. and MARINS, M.D.M. (1997). Contaminação de água subterrânea por derramamento de gasolina: o problema é grave? Engenharia Sanitária e Ambiental. v.2, p. $50-54$

CORSEUIL, H.X.; ALVAREZ, P.J.J. (1996). Implications of the presence of ethanol on intrinsic bioremediation of BTEX plumes in Brasil: Hazardous Waste and Hazardous Materials. v.13, n.2, p.213-221.

DAMIANOVIC, M.H.RZ. (1997) Degradação de Pentaclorofenol, (Pcp) em Reatores Anaeróbios Horizontais de Leito Fixo (RAHLF). 176p. Tese (doutorado) - Escola de Engenharia de São Carlos, Universidade de São Paulo. São Carlos. 1997.

DILLALO, R.; ALBERTSON, O.E. (1961). Volatile acids by direct titration. Journal of Water Pollution Control federation. v. 33, n.4, p.356-365.

DOLFING, J.; ZEYER, P.; BINDER-EICHER, P.; SCHWARZENBACH, R. P. (1990). Isolation and Characterization of a Bacterium that Mineralizes Toluene in the Absence of Molecular Oxygen. Archieves of Microbiology, v.154, p. 336-341.

DOMINGUES, M.R. (2001) Avaliação da metanogênese e sulfetogênese em reatores anaeróbios em batelada de leito fixo, sob condições termofílicas. Dissertação (Mestrado) - Escola de Engenharia de São Carlos, Universidade de São Paulo. São Carlos. 2001

DORONINA, N.V.; TROTSENKO, Y.AV.; KRAUSOWA, I. and N. E. SUZINA. (1998). Paracoccus methylutens sp. nov.-a new aerobic facultatively methylotrophic bacterium utilizing dichloromethane. Systematic Applied Microbiology. v. 21, p.230236.

DSM - Scientific services of culture collections. (1991). Curso ministrado na Fundação Tropical de Pesquisas e Tecnologia André Tosello, Campinas - SP 
EDWARDS, E.A., and GRBIC-GALIC, D. (1992). Complete mineralization of benzene by aquifer microorganisms under strictly anaerobic conditions. Applied and Environmental Microbiology. v.58, n.8, p.2663-2666.

ÉLMEN J.; PAN, W.; LEUNG S, Y.; MAGYAROSY, A.; KEASLING, J. D. (1997). Kinetics of toluene degradation by a nitrate-reducing bacterium isolated from a ground water aquifer. Biotechnology and bioengineering. v.55, n.1, p. 82-90.

EVANS, P.J.; MANG D, T.; KIM, K.S.; YOUNG, L.Y. (1991). Anaerobic degradation of toluene by a denitryfyng bacterium. Applied and Environmental Microbiology. v.57, n.4, p.1139-1145.

FERNANDES, B.S. (2005). Influencia da origem do inóculo e da adição de sulfato sobre a degradação de BTX em reator anaeróbio horizontal de leito fixo. 78p. Tese (Mestrado) - Escola de Engenharia de São Carlos, Universidade de São Paulo. São Carlos .2005.

FRIES, M.R.; ZHOU, J.; CHEE-SANFORD, J. and Tiedje, J. M. (1994). Isolation, characterization, and distribution of denitrifying toluene degraders from a variety of habitats. Applied and Environmental Microbiology. v.60, p.2802-2810.

GAMBLE, T.N.; BETLACH, H.R.; and TIEDJE, J. M. (1977). Numerically dominant denitrifying bacteria from world soils. Applied and Environmental Microbiology. v.33, p.926-939.

GIBSON, D.T.; and SUBRAMANIAN, V. (1984). Microbial degradatin of aromatic hydrocarbons. p.181-252. In: GIBSON, D.T. (ed), Microbial degradation of organic compounds. Marcel Dekker, Inc., New York.

GRIFFITHS, R. I.; WHITELEY, A. S.; O'DONNELL, A. G. and BAILEY, M. J. (2000). Rapid method for coextraction of DNA and RNA from natural environments for analysis of ribosomal DNA and rRNA-based microbial community compositon. Applied and Environmental Microbiology. v. 66, p.5488-5491.

GRISHCHENKOV. V.G.; TOWNSEND, R.T.; McDONALD, T.J.; AUTENRIETH, R.L.; BONNER, J.S. and Boronin, A.M. (2000). Degradation of petroleum hydrocarbons by facultative anaerobic bacteria under aerobic and anaerobic conditions. Process of Biochemistry.v.35, p.889-896.

HAMED, T.A.; BAYRAKTAR, E.; MEHMETOGLU, T. and MEHMETOGLU, U. (2003). Substrate interactions during the biodegradation of benzene, toluene and phenol mixtures. Process of Biochemistry. v.39, p.27-35. 
HEIDER, J.; SPORMANN, A. M.; BELLER, H. R.; WIDDEL, F.(1999). Anaerobic bacterial metablism of hydrocarbons. FEMS Microbiology Review. v.22, p.459-473.

HESS, A.; ZARDA, B.; HAHN, D.; HANER, A.; STAX, D.; HÖHENER, P.; ZEYER, J. (1997). In Situ Analysis of Denitrifying Toluene and $m$-Xylene Degrading Bacteria in a Diesel Fuel- contaminated Laboratory Aquifer Column. Applied and Evironmental Microbiology. v. 63, p. 2136-2141.

HOUBRON, E.; TORRIJOS, M.; CAPDEVILLE, B. (1999). An alternative use of biogas applied in water denitrification. Water Science and Technology. v.40, n.8, p.115-122.

HUNT, J. R.; SITTAR, N.; and UDELL, K. S. (1988). Non-aqueous phase liquid transport and cleanup: 1-Analysis of mechanisms. Water Resouces Research. v.24, p.1247-1258.

KAO, C. and BORDEN, R. C. (1997). Site specific variability in BTEX biodegradation under denitrifying conditions. Ground water. v.35, n.2, p.305-311.

KAPLAN, C.W. and KITTS C.L. (2004). Bacterial succession in a petroleum land treatment unit. Applied and Environmental Microbiology. v.70, p.1777-1786.

KAZUMI, J.; CALDWELL, M. E.; SUFLITA, J. M.; LOVELY, D.R.; and YOUNG, L. Y. (1997). Anaerobic degradation of benzene in diverse anoxic environments. Environmental Science Technology. v.31, p.813-818.

KUHN, E. P.; ZEYER, J.; EICHER, P.; and SCHWARZENBACH, R. P. (1988). Anaerobic degradation of alkylated benzenes in denitrifying laboratory aquifer columns. Applied and Environmental Microbiology. v.54, n.2, p.490-496.

KÜHNER, S.; WÖHLBRAND, L.; FRITZ, I.; WRUCK, W.; HULTSCHIG, P.; KUBE, M.; REINHARDT, R. and RABUS, R. (2005). Substrate-dependent regulation of anaerobic degradation pathways for toluene and ethylbenzene in a denitrifying bacterium, srain EbN1. Journal of Bacteriology. v.187, p. 1493-1503.

LIPSKI, A.; REICHERT, K.; REUTER, B.; SPRÖER, C.; and ALTENDORF, K. (1998). Identification of bacterial isolates from biofilters as Paracoccus alkenifer sp. nov. and Paracoccus solventivorans with emended description of Paracoccus solventivorans. International Journal of Systematic Bacteriology. v.48, p.529-536. 
LITTLE, J.C.; DAISEY, J.M.; and NAZAROFF, W.W. (1992). Transport of subsurface contaminants into buildings. Environmental Science and Technology. v. 26, p.20582065

LOVLEY, D.R.; COATES, J.D.; WOODWARD, J.C. and PHILLIPS, E.J.P. (1995). Benzene oxidation coupled to sulfate reduction. Applied and Environmental Microbiology. v.61, n.3, p.953-958.

LOVLEY, D.R; WOODWARD, J.C. and CHAPELLE, F.H. (1996). Rapid anaerobic benzene degradation with a variety chelated Fe(III)forms. Applied and Environmental Microbiology. v.62, p.288-291.

MACKAY, D. and CHERRY, J.A. (1989). Groundwater contamination: Pump and treat remediation. Environmental Science and Technology. v. 23, p.7-13.

MADIGAN, M.T.; MARTINKO, J.M.; PARKER, J. (1997). Brock. Biology of microorganisms. 8th Prentice Hall, Inc USA

MORAES, E.M; ADORNO, M.A.T; ZAIAT, M; FORESTI, E. (2000). Determinação de ácidos voláteis por cromatografia gasosa em efluentes de reatores anaeróbios tratando resíduos líquidos e sólidos. In: VI OFICINA E SEMINÁRIO LATINOAMERICANO DE DIGESTÃO ANAERÓBIA, 2000. Recife, PE. Anais, v.2, p. 235-238.

MUYZER, G.; WAAL, E.C.; UITTERLINDEN, A.G. (1993). Denaturing gradient gel eletrophoresis of PCR - amplified 16S rDNA - A new molecular approach to analyse the genetic diversity of mixed microbial communities. Applied and Environmental Microbiology. v.59, n.3, p. 695 - 700.

NAKAGAWA, T.; SATO, S.; YAMAMOTO, Y.; FUKUI, M. (2002). Successive changes in community structure of an ethylbenzene-degrading sulfate-reducing consortium. Water Research. v.36, p.2813-2823.

NARDI, I. R. (2002) Degradação de benzeno, tolueno, etilbenzeno e xilenos (BTEX) em reator anaeróbio horizontal de leito fixo (RAHLF). Tese (Doutorado), Escola de Engenharia de São Carlos, Universidade de São Paulo, São Carlos. 2002.

NIELSEN, T. A.; LIU, W-T.; FILIPE, C.; GRADY, L.; MOLIN, S.; STAHL, D. A. (1999). Identification of a novel group of bacteria in sludge from a deterioted biological phosphorus removal reactor. Applied and Environmental Microbiology. v.65, p.12511258 . 
OHARA, M.; KATAYAMA, Y.; TSUZAKI, M.; NAKAMOTO, S. and KURAISHI, H.. (1990). Paracoccus kocurii sp. nov., a tetramethylammonium-assimilating bacterium. International Journal of Systematic Bacteriology. v.40, p.292-296.

OLIVEIRA, S.V.W.B.; MORAES, E.M.; ADORNO, M.A.T.; VARESCHE, M.B.A.; FORESTI, E.; ZAIAT, M. (2004). Formaldehyde Degradation in an Anaerobic PackedBed Biorreactor. Water Research, v.38, p.1685-1694.

PHELPS, C.D. and YOUNG, L.Y. (2001). Biodegradation of BTEX under anaerobic conditions: a review. Advaces in Agronomy.v.70, p.329-357.

PHELPS, C.D.; YOUNG, L.Y. (1999). Anaerobic biodegradation of BTEX and gasoline in various aquatic sediments. Biodegradation. v.10, p.15-25.

POCHANA, K.; KELLER, J. (1999). Study of factors affecting simultaneous nitrification and denitrification (SND). Water science technology. v.39, n.6, p.61-68.

PUKALL, R.; LAROCHE, M.; KROPPENSTEDT, R. M.; SCHUMANN, P.; STACKEBRANDT, E. and ULBER, R.. (2003). Paracoccus seriniphilus sp. nov., an Lserine-dehydrataseproducing coccus isolated from the marine bryozoan Bugula plumosa. International Journal of Systematic Evol. Microbiology. v.53, p.443-447.

RABUS, R. and WIDDEL, F. (1995). Anaerobic degradation of ethylbenzene and other aromatic hydrocarbons by new denitrifying bacteria. Archives Microbiology.v.163, p. 96-103.

RAJAPAKSE, J. P.; SCUTT, J. E. (1999). Denitrification with natural gas and various new growth media. Water Research.v. 33,n.18, p.3723-3734.

REINHARD, M.; GOODMAN, N. L. (1984). Occurrence and distribuition of organic chemicals in two landfill leachate plumes. Environmental Science and Technology. v.18, n.12, p.953-961.

RIBEIRO, R. (2005). Recuperação de águas contaminadas com gasolina utilizando reatores de leito fixo. 186p. Tese (Doutorado) - Escola de Engenharia de São Carlos, Universidade de São Paulo. São Carlos.2005.

RIDGWAY, H. F.; SAFARIK, J.; PHIPPS, D. (1990). Identification and catabolic activity of well-derived gasoline-degrading bacteria from a contaminated aquifer. Applied and Environmental Microbiology. v.56, p.3565-3575. 
RIPLEY, L. E.; BOYLE, W. C.; CONVERSE, J. C. (1986). Improved alkalimetric monitoring for anaerobic digestion of high-strength wastes. Journal of water Pollution Control Federation, v.58, n.5, p.406-411.

ROBERSTON, L. A. and KUENEN, J. G. (1983) Thiosphaera pantotropha gen. nov. sp. nov., a facultative anaerobic, facultatively autotrophic sulphur bacterium. Journal of Gen. Microbiology. v.129, p.2847-2855.

SAKAMOTO, I. K. (2001). Comparação da estrutura de comunidades microbianas presentes em sistemas de lodos ativados modificados para remoção biológica de fósforo em excesso, utilizando a técnica de eletroforese em gel de gradiente desnaturante (DGGE). 162p. Tese (Doutorado) - Escola de Engenharia de São Carlos, Universidade de São Paulo, São Carlos. 2001.

SANTOS, S. G. (2004). Utilização de metanol, etanol e metano como doadores de elétrons para a desnitrificação. 144p. Tese (Doutorado) - Escola de Engenharia de São Carlos, Universidade de São Paulo, São Carlos. 2004

SCHNEIDER, M. R.; CORSEUIL, H. X.; ROSÁRIO, M. (2005). Weathering of ethanol-blended gasoline in aquifers - a field experiment. In: The International Conference on Environmental Science and Technology. New Orleans. The International Conference on Environmental Science and Technology. New Orleans : National Academy of Science, 2005. v. 1. p. 100-106.

SCHOCHER, R. J.; SEYFRIED, B.; VAZQUEZ, F. and ZEYER, J. (1991). Anaerobic degradation of toluene by pure cultures of denitrifying bacteria. Archieves of Microbiology. v.157, p. 7-12.

SHAPLEIGH, J.P. (2000) The Denitrifying Prokaryotes Release 3.1. The Prokaryotes, a evolving electronic resource for the microbiological community.

SHIEH, W. K.; MULCAHY, L. T. (1986). Experimental determination of intrinsic kinetic coefficients for biological wastewater treatment systems. Water science technology. v.18, p.1-10.

SHIM, H.; YANG, S. T. (1999). Biodegradation of benzene, toluene, ethylbenzene and o-xylene by coculture of Pseudomonas putida and Pseudomonas fluorescence immobilized in a fibrous-bed bioreactor. Journal of Biotechnology. v.67, p.9-12.

SHINODA, Y.; SAKAI, Y.; UE, M.; HIRAISHI, A.; and KATO, N. (2000). Isolation and Characterization of a New Denitrifying Spirillum Capable of Anaerobic Degradation of Phenol. Applied and Environmental Microbiology. v.66, p.1286-1291 
SHINODA, Y.; SAKAI, Y.; UENISHI, H.; UCHIHASHI, Y.; HIRAISHI, A.; YUKAWA, H.; YURIMOTO, H.; and KATO, N. (2004). Aerobic and anaerobic toluene degradation by a newly isolated denitrifying bacterium, Thauera sp. strain DNT-1. Applied and Environmental Microbiology. v.70, p. 1385-1392.

SILLER, H.; RAINEY, F.A.; STACKEBRANDT, E. and WINTER, J.(1996). Isolation and characterization of a new gram-negative, acetone-degrading, nitrate-reducing bacterium from soil, Paracoccus solventivorans sp. nov. International Journal of Systematic Bacteriology. v.46, p.1125-1130.

SILVA, R.L.B.; BARRA, C.M.; MONTEIRO, T.C.N.; BRILHANTE, O.M. (2002). Estudo da contaminação de poços rasos por combustíveis orgânicos e possíveis consequiências para a saúde pública no Município de Itaguaí, Rio de Janeiro, Brasil. Caderno da. Saúde Pública. v.18, n.6, p.1599-1607.

SO, C.M. and YOUNG, L.Y. (1999). Isolation and characterization of a sulfate-rducing bacterium that anaerobically degrades alkanes. Applied and Environmental . Microbiology. v.65, n.7, p.2060-2976

SONG, B.; YOUNG, L.Y.; PALLERONI, N.J. (1998). Identification of denitrifier strain $\mathrm{T} 1$ as Thauera aromatica and proposal for emendation of the genus Thauera definition. International Journal of Systematic Bacteriology. v.48, p.889-894.

SONG, B; HAGGBLOM, M.M.; ZHOU, J.; TIEDJE, J.M.; PALLERONI, N.J. (1999). Taxonomic Characterization of Denitrifying Bacteria that Degrade Aromatic Compounds and Description of Azoarcus toluvarans sp. nov. and Azoarcus toluclasticus sp. nov. International Journal of Systematic Bacteriology. v.49, p. 1129-1140.

SPRINGER, N.; LUDWIG, W.; PHILIPP, B. and SCHINK, B. (1998). Azoarcus anaerobius sp. nov., a resorcinol-degrading, strictly anaerobic, denitrifying bacterium International Journal of Systematic Bacteriology. vol. 48, p. 953-956

STANDARD METHODS FOR THE EXAMINATION OF WATER AND WASTEWATER (1998). $19^{\text {th }}$ ed. Amer. Public Health Assoc., Americ. Water Works Association, Water Pollution Control Federation, Washington, D.C., 1134p.

STONER, D.L. (1994). Hazardous organic waste amenable to biological treatment, 125. In: Stoner D. L. (ed). Biotechnology for the treatment of hazardous waste. Lewis Publisherrs. Boca Raton. 
TIEDJE, J.M. (1988) Ecology of denitrification and dissimilatory nitrate reduction to ammonium. In: Biology of Anaerobic Microorganisms. Zehnder, J. B. (editor). John Wiley \& Sons, New York.

TOUZEL, J.P.; and ALBAGNAC, G. (1983). Isolation and characterization of Methanococcus mazei strain MC3. FEMS Microbiology Letters. v.16, p.241-245.

VARESCHE, M.B.A. (1997). Estudo com Bacterias Fototróficas Anoxigênicas: Enriquecimento, Isolamento, Caracterização Nutricional e Cinética de Crescimento. Tese (Doutorado) - Escola de Engenharia de São Carlos, Universidade de São Paulo, São Carlos. 1997.

VAZOLLER, R.F. (1995). Avaliação do ecossistema microbiano de um biodigestor anaeróbio de fluxo ascendente e manta de lodo, operando com vinhaça sob condições termofílicas. 259p. Tese (Doutorado) - Escola de Engenharia de São Carlos, Universidade de São Paulo, São Carlos. 1995.

YOSHINARI, T.; KNOWLES, R. (1976). Acetylene inhibition of nitrous oxide reduction by denitrifying bacteria. Biochemistry and Biophysics Research Community. v.69, p. 705-10.

ZAIAT, M.; VIEIRA, L.G.T.; FORESTI, E. (1997). Spatial and temporal variations in monitoring performace parameters in horizontal-flow anaerobic immobilized sludge (HAIS) reactor. Water Research. v,31, p. 1760-1766.

ZEHNDER, A.J.B. (1988). Biology of Anaerobic Microorganisms. John Wiley \& Sons, Inc.

ZEYER and KEARNEY (1982). Microbial degradation of para-anilina as sole carbon and nitrogen source. Pestic. Biochem. Fisiol., v.17, p.215-223

ZHOU, J.; FRIES, M. R.; CHEE-SANFORD, J. C. and TIEDJE, J. M. (1995). Philogenetic analyses of a new group of denitrifiers capable of anaerobic growth on toluene and description of Azoarcus toluliticus sp. nov. International Journal of Systematic Bacteriology. v.45, n.3, p.500-506.

Zhu, X.; ZHONG, T.; PANDYA, Y. and JOERGER, R.D. (2002). 16S rRNA-based analysis of microbiota from the cecum of broiler chickens. Applied and Environmental Microbiology.v.68, p.124-137. 
ZINDER, S.H.; CARDWELL, S.C.; ANGUISH, T.; LEE, M.; KOCH, M. (1984). Methanogenesis in a thermophilic $\left(58^{\circ} \mathrm{c}\right)$ anaerobic digestor. Methanothrix sp. as an important acetoclastic methanogen. Apllied and Environmental Microbiology. v.47, p.796-807. 
APÊNDICE A - Curvas de calibração 
CURVAS PARA A BENZENO

Curva baixa para benzeno - concentração 0,1 a 2,0 mg/L

conc area benzeno área Clorobenz FR média FR

$\begin{array}{lllll}0,1 & 684 & 28547 & 0,02 & 0,02 \\ 0,1 & 759 & 39746 & 0,02 & \\ & & & & \\ 0,5 & 3575 & 39935 & 0,09 & 0,09 \\ 0,5 & 3520 & 37764 & 0,09 & \\ & & & & \\ 1,0 & 6354 & 34883 & 0,18 & 0,18 \\ 1,0 & 6300 & 34140 & 0,18 & \end{array}$

$\begin{array}{cc}\text { Conc } & \text { média FR } \\ 0,1 & 0,02 \\ 0,52 & 0,09 \\ 1 & 0,18\end{array}$

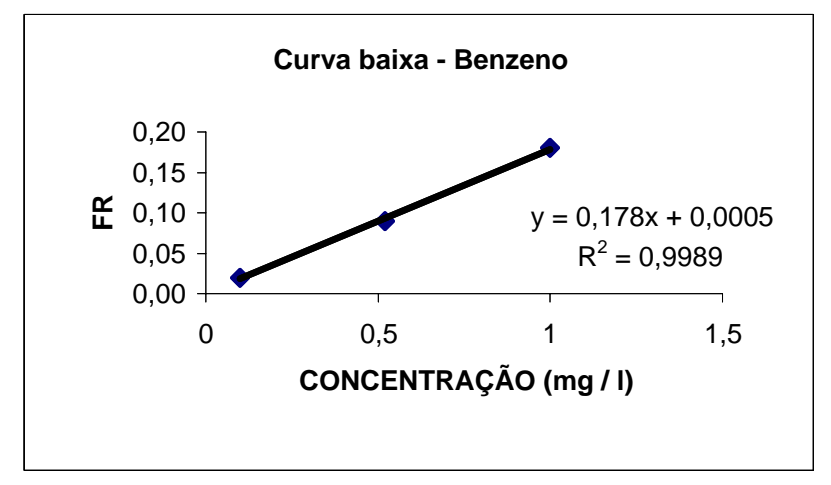

Curva alta para benzeno - concentração 2,0 a 30,0 mg/l

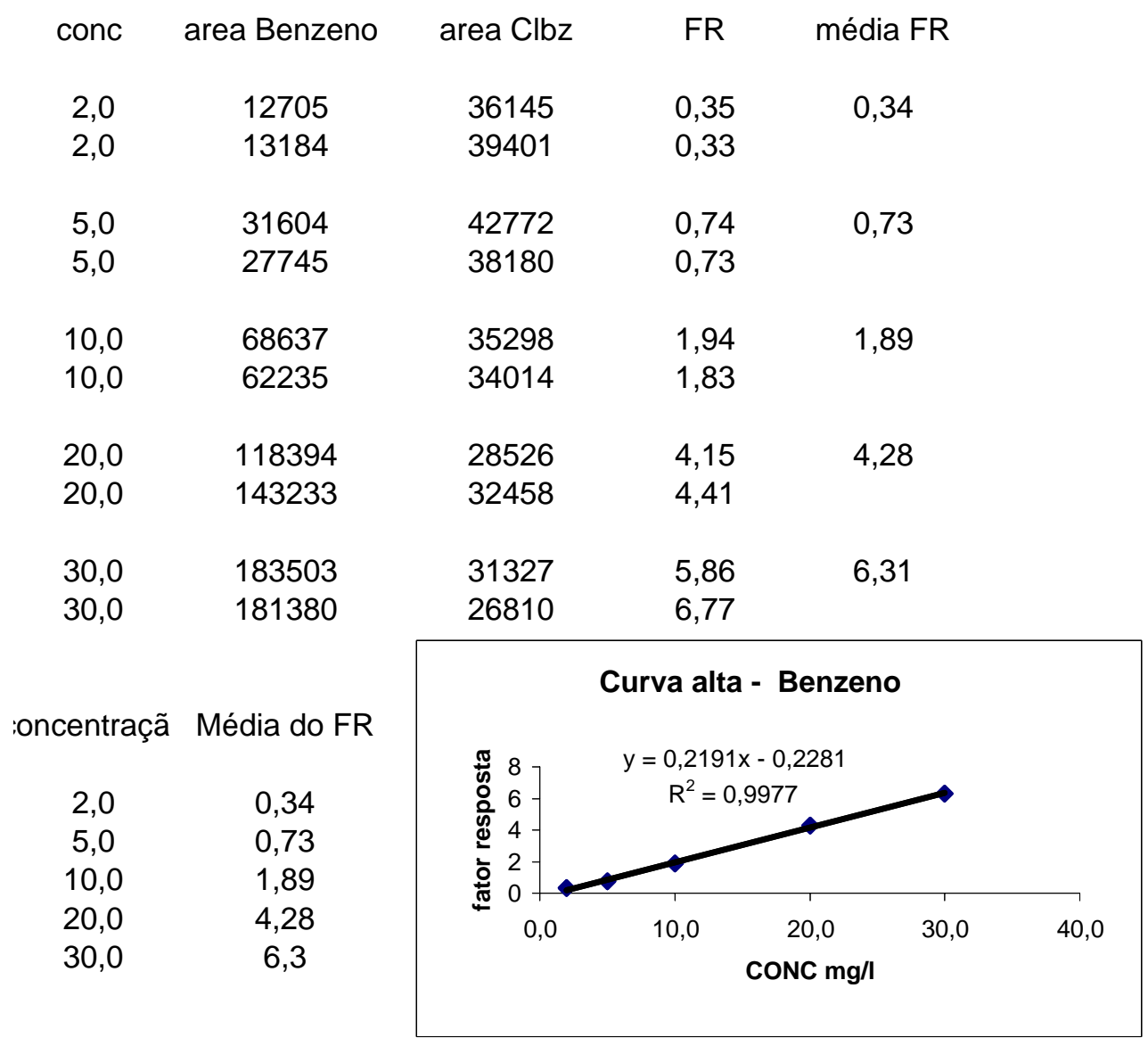


Curva baixa para tolueno - concentração 0,1 a 2,0 mg/l

$\begin{array}{ccccc}\text { concentração } & \text { area Tolueno } & \text { area Clorobenz } & \text { Fator Resposta } & \text { média FR } \\ 0,1 & 361 & 19646 & 0,018 & 0,018 \\ 0,1 & 116,6 & 6347 & 0,018 & \\ & & & & \\ 0,5 & 1804 & 19027 & 0,095 & 0,1825 \\ 0,5 & 816 & 5191 & 0,157 & \\ & & & & \\ 1,0 & 3445 & 10979 & 0,314 & 0,3125 \\ 1,0 & 1999 & 6436 & 0,311 & \\ & & & & 0,6595 \\ 2,0 & 4266 & 6214 & 0,687 & \end{array}$

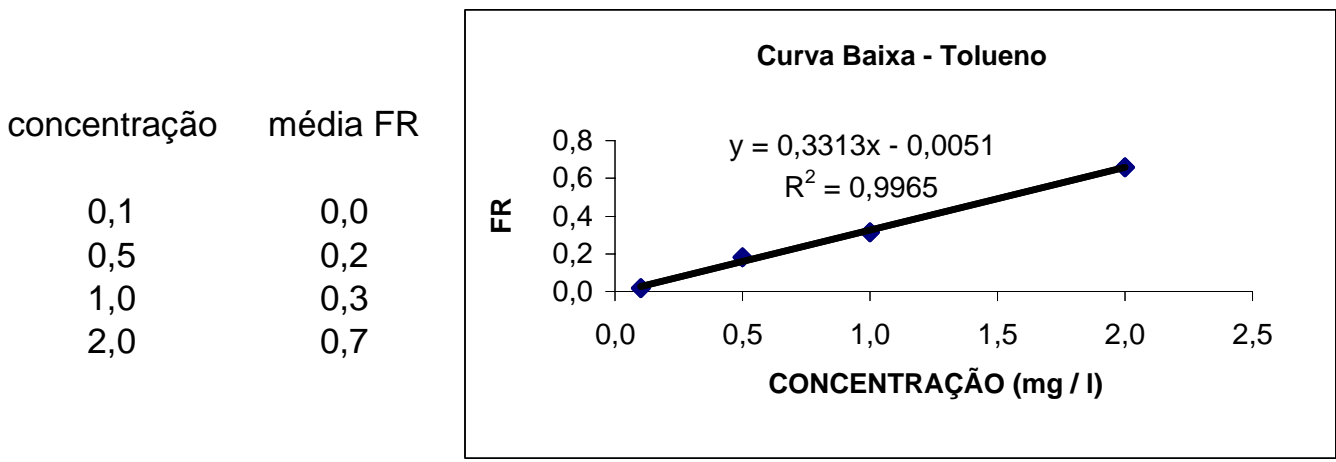

Curva alta para tolueno - concentração 2,0 a 30,0 mg/l concentração area Tolueno area Clorobenz Fator Resposta média FR

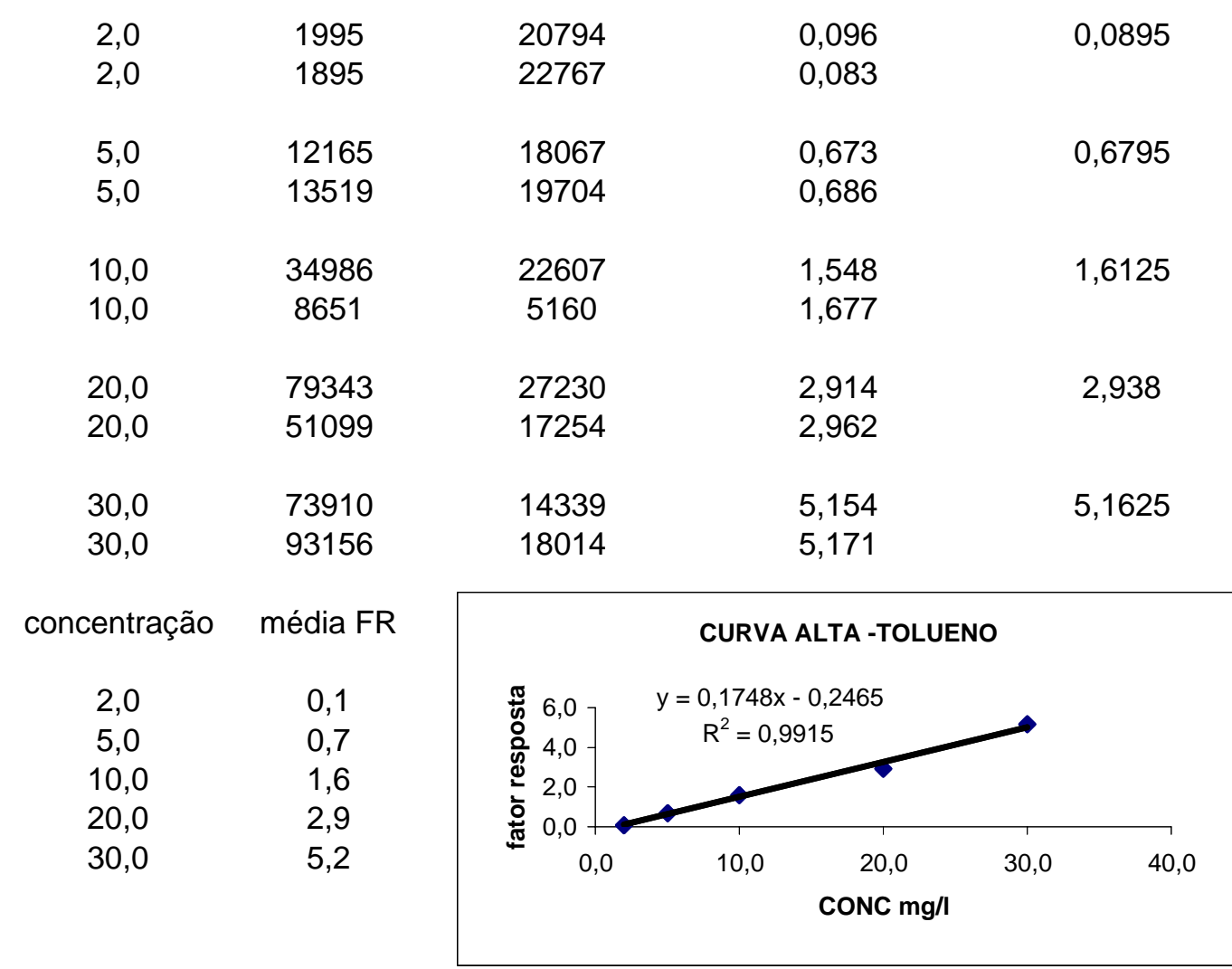


Curva baixa para etilbenzeno - concentração 0,1 a 2,0 mg/L

concentração area etilbz area Clorobz

Fator Resposta

Média FR

$\begin{array}{lrrrr}0,1 & 582 & 9985 & 0,06 & 0,06 \\ 0,1 & 761 & 13009 & 0,06 & \end{array}$

$\begin{array}{ccccc}0,5 & 1077 & 13326 & 0,08 & 0,08 \\ 0,5 & 806 & 10106 & 0,08 & \end{array}$

$\begin{array}{lllll}1,0 & 1931 & 11285 & 0,17 & 0,17 \\ 1,0 & 2260 & 13587 & 0,17 & \end{array}$

$\begin{array}{lllll}2,0 & 3781 & 9394 & 0,40 & 0,40\end{array}$

concentração média FR

$\begin{array}{ll}0,5 & 0,1 \\ 1,0 & 0,2 \\ 2,0 & 0,4\end{array}$

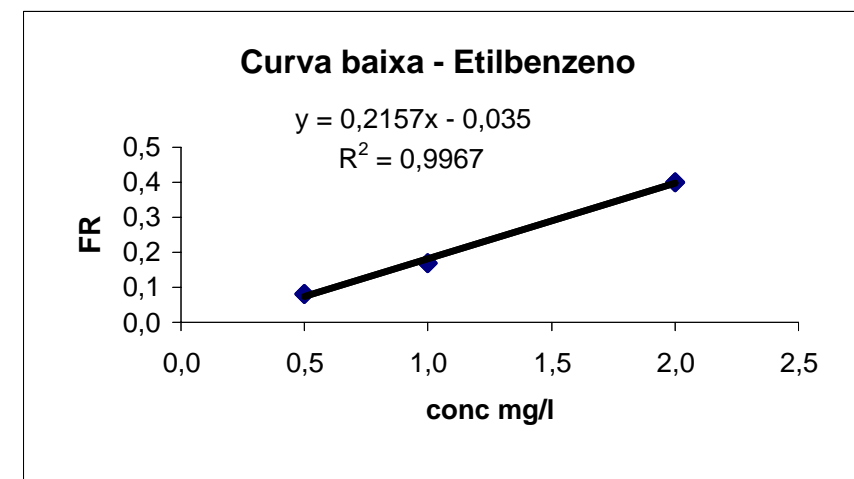

Curva alta para etilbenzeno - concentração de 2,0 A 30,0 mg/l concentração area etilbz area Clorobz Fator Resposta

Média FR

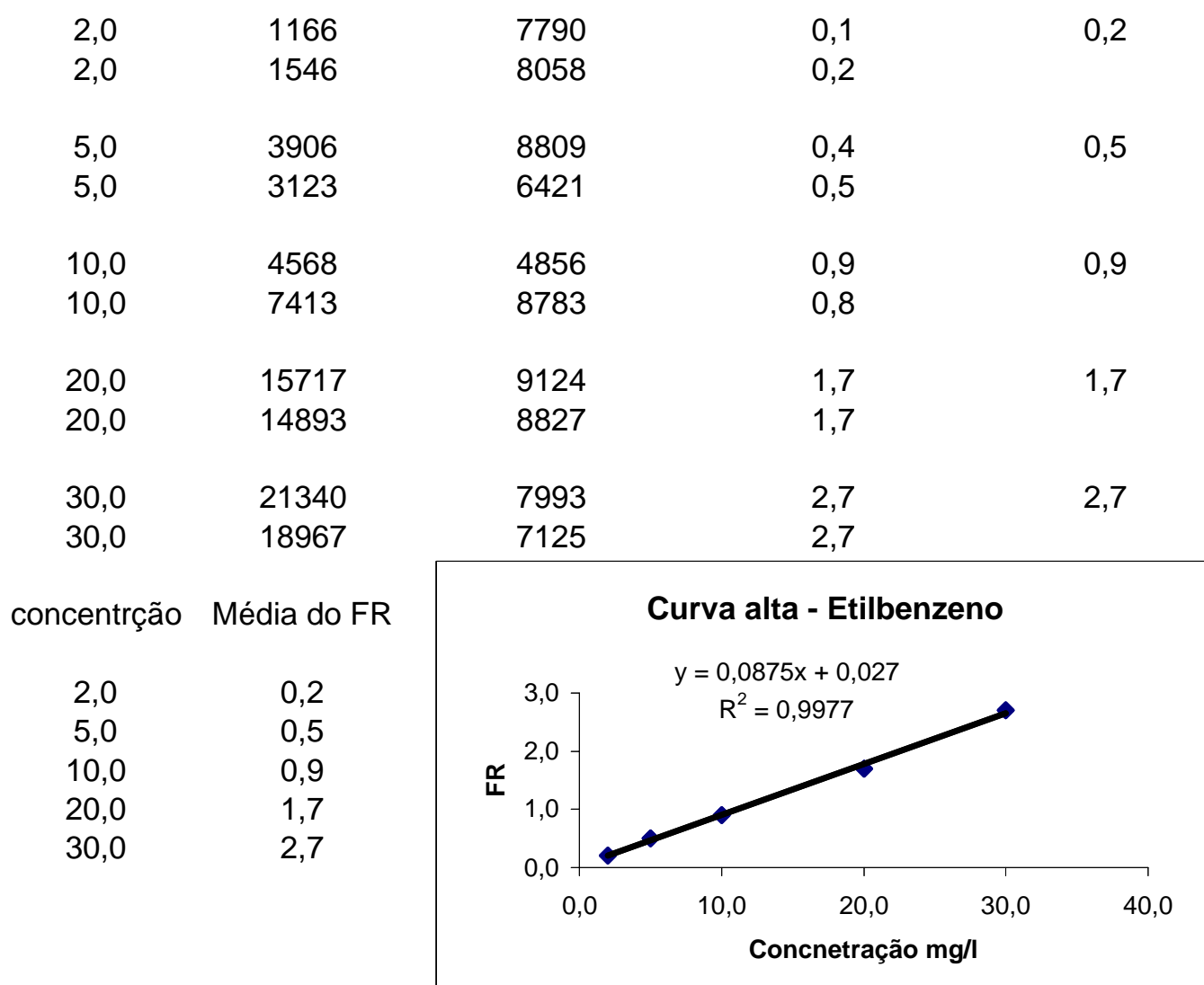


Curva baixa para o-xileno - concentração de 0,1 a 2,0 mg/l concentração area O-xileno za Clorobenzer Fator Resposta média FR

$\begin{array}{lllll}0,1 & 1304 & 32263 & 0,04 & 0,04 \\ 0,1 & 1417 & 35707 & 0,04 & \\ 0,5 & 3004 & 37739 & 0,08 & 0,08 \\ 0,5 & 2602 & 34420 & 0,08 & \\ & & & & \\ 1,0 & 5154 & 34198 & 0,15 & 0,15 \\ 1,0 & 5207 & 35125 & 0,15 & \\ 2,0 & 30508 & 8665 & 0,28 & 0,29 \\ 2,0 & 32403 & 9624 & 0,30 & \end{array}$

$\begin{array}{cr}\text { concentração } & \text { média FR } \\ 0,1 & 0,04 \\ 0,5 & 0,08 \\ 1 & 0,15 \\ 2 & 0,29\end{array}$

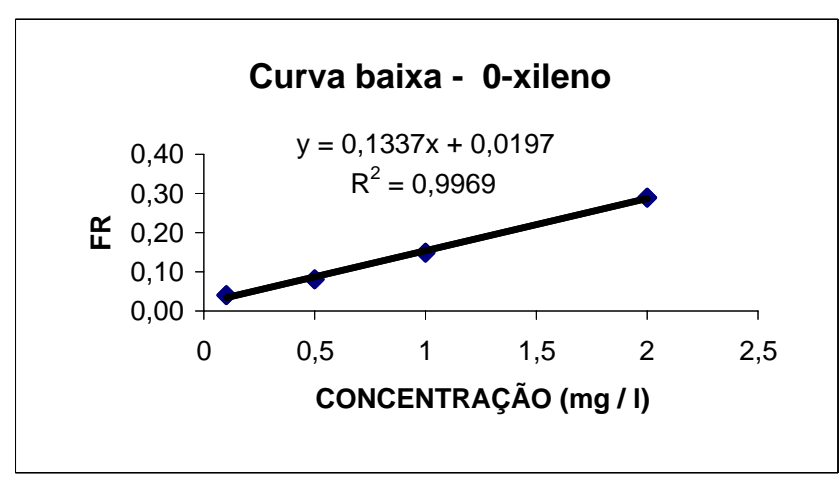

Curva alta para o-xileno - concentração de 2,0 A 30,0 mg/l concentração area O-xileno ırea Clorobenz Fator Resposta

média FR

$\begin{array}{lcccc}2,0 & 30508 & 8665 & 0,28 & 0,29 \\ 2,0 & 32403 & 9624 & 0,30 & \\ 5,0 & 23232 & 32849 & 0,71 & 0,74 \\ 5,0 & 29642 & 38546 & 0,77 & \\ & & & & 1,49 \\ 10,0 & 49950 & 34691 & 1,44 & \\ 10,0 & 44662 & 29097 & 1,53 & 3,24 \\ & & & & \\ 20,0 & 99836 & 30599 & 3,26 & 4,62 \\ 20,0 & 108917 & 33879 & 3,21 & \\ & & & & \\ 30,0 & 140028 & 30011 & 4,67 & \\ 30,0 & 138947 & 30393 & 4,57 & \end{array}$

concentração Média do FR

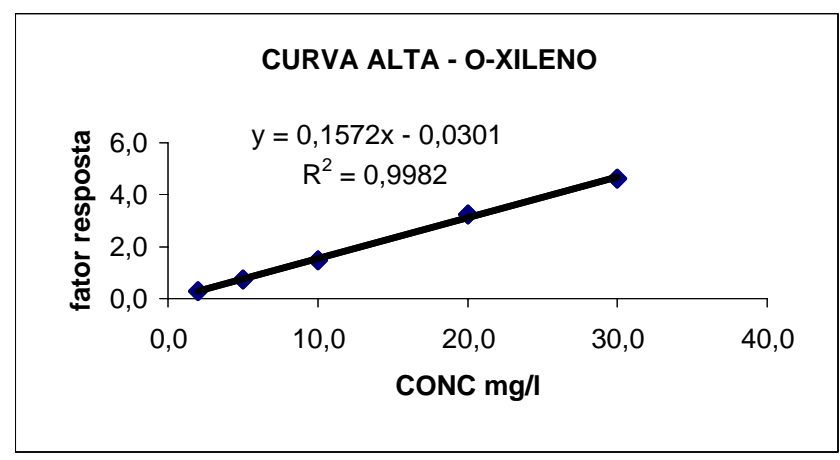


Curva baixa para m-xileno - concetração 0,1 a 2,0 mg/L

concentração area m-xileno Área Clorobz Fator Resposta

média FR

$\begin{array}{lcccc}0,1 & 1342 & 39614 & 0,034 & 0,03 \\ 0,1 & 1584 & 67150 & 0,024 & \\ 0,5 & 2890 & 34407 & 0,084 & 0,08 \\ 0,5 & 3458 & 41434 & 0,083 & \\ & & & & 0,15 \\ 1,0 & 4539 & 30188 & 0,150 & \\ 1,0 & 4616 & 32447 & 0,142 & 0,31 \\ 2,0 & 30839 & 103687 & 0,297 & \\ 2,0 & 9677 & 30851 & 0,314 & \end{array}$

concentração média FR

$\begin{array}{ll}0,1 & 0,0 \\ 0,5 & 0,1 \\ 1,0 & 0,2 \\ 2,1 & 0,3\end{array}$

Curva baixa para $\mathrm{m}$-xileno

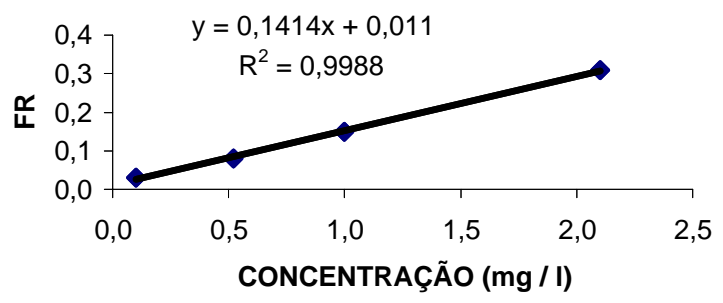

Curva alta para m- xileno - Concentração de 2,0 A 30,0 mg/l concentração area m-xileno Área Clorobz Fator Resposta

média FR

$\begin{array}{lcccc}2,0 & 13413 & 83045 & 0,162 & 0,14 \\ 2,0 & 3583 & 30932 & 0,116 & \\ & & & & 0,36 \\ 5,0 & 20788 & 57992 & 0,358 & \\ 5,0 & 11061 & 31368 & 0,353 & 0,70 \\ 10,0 & 19267 & 25484 & 0,756 & \\ 10,0 & 17051 & 26279 & 0,649 & 1,75 \\ 20,0 & 46411 & 27135 & 1,710 & \\ 20,0 & 48779 & 27161 & 1,796 & 2,52 \\ 30,0 & 256730 & 100661 & 2,550 & \\ 30,0 & 89299 & 35745 & 2,498 & \end{array}$

concentração Média do FR

$\begin{array}{cc}2,0 & 0,1 \\ 5,0 & 0,4 \\ 10,0 & 0,7 \\ 20,0 & 1,8 \\ 30,0 & 2,5\end{array}$

\section{Curva alta $m$-XILENO}

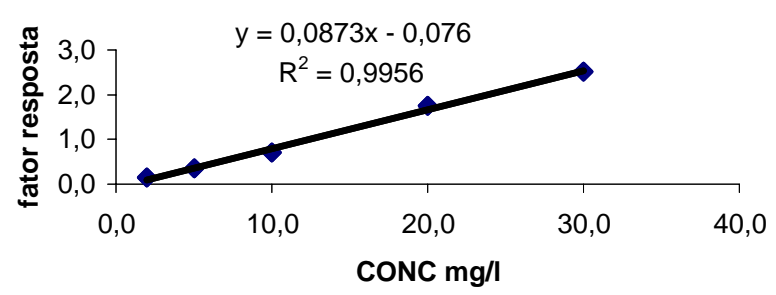


Curva baixa p-xileno - concentração 0,1 a $2,0 \mathrm{mg} / \mathrm{L}$

concentração area p-xileno ea Clorobenzer Fator Resposta média FR

$\begin{array}{ccccc}0,1 \mathrm{a} & 484 & 20216 & 0,02 & 0,02 \\ 0,1 \mathrm{~b} & 425 & 18270 & 0,02 & \\ & & & & \\ 0,5 \mathrm{a} & 1918 & 15842 & 0,12 & 0,11 \\ 0,5 \mathrm{~b} & 3034 & 29926 & 0,10 & \\ & & & & 0,29 \\ 1,0 \mathrm{~A} & 5530 & 19249 & 0,29 & \\ 1,0 \mathrm{~B} & 6176 & 21586 & 0,29 & 0,53 \\ 2,0 \mathrm{~A} & 8190 & 14728 & 0,56 & \\ 2,0 \mathrm{~B} & 9165 & 18074 & 0,51 & \end{array}$

$\begin{array}{cr}\text { concentração } & \text { média } \\ 0,1 & 0,0 \\ 0,5 & 0,1 \\ 1,0 & 0,3 \\ 2,0 & 0,5\end{array}$

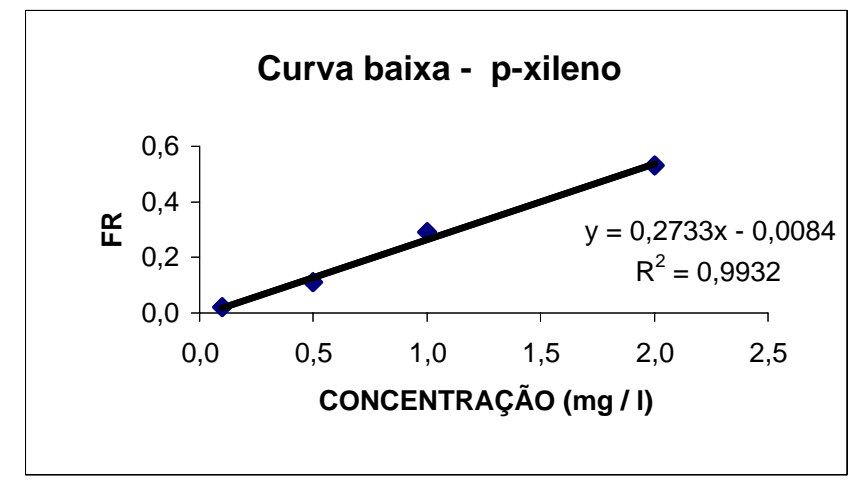

Curva alta p-xileno - Concentração de 5,0 a $\mathbf{3 0 , 0} \mathrm{mg} / \mathrm{l}$

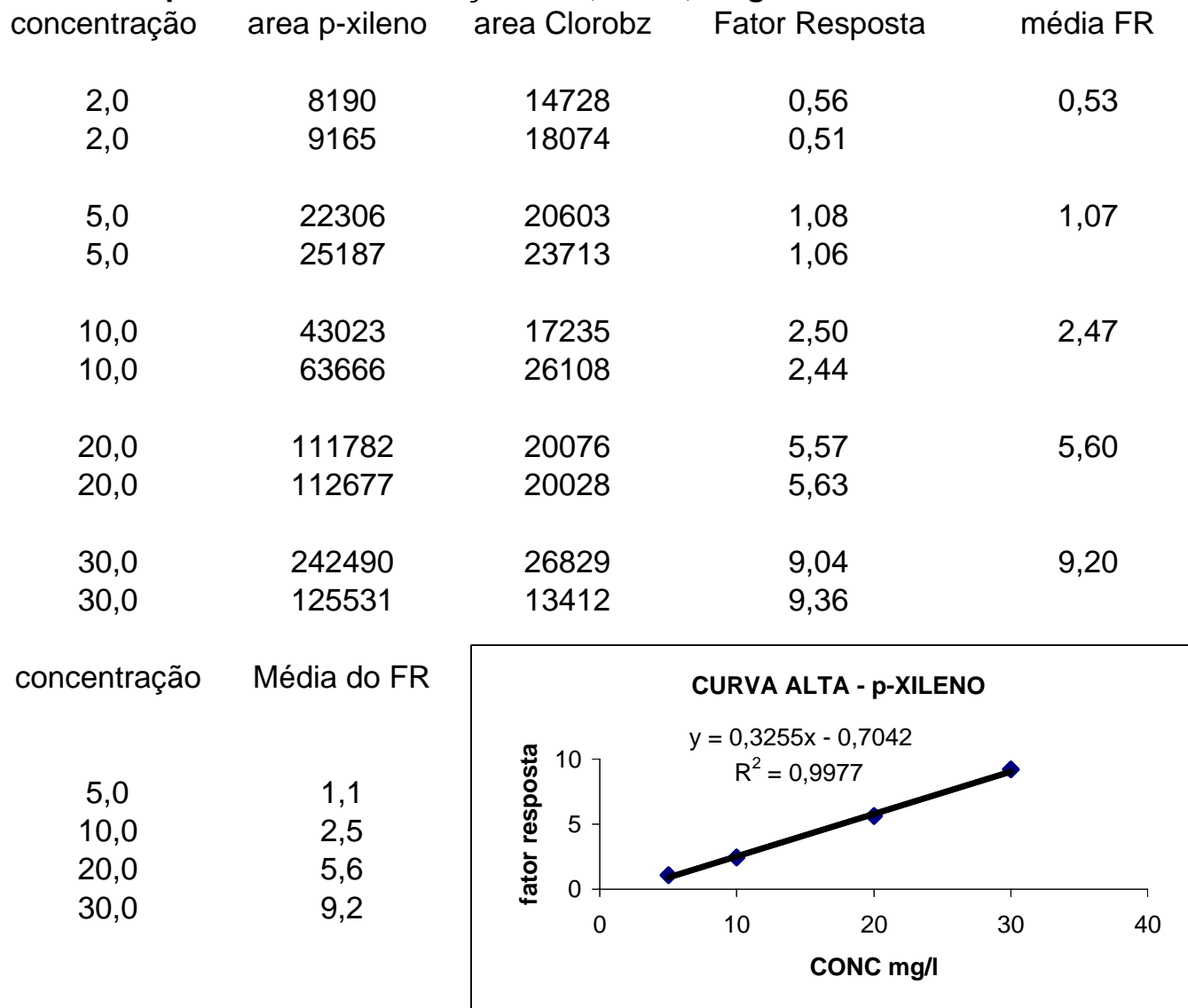




$\begin{array}{cr}\text { concentração } & \text { FR Benzen } \\ & \\ 0,2 & 0,07 \\ 0,5 & 0,09 \\ 1,0 & 0,25 \\ 4,0 & 1,58 \\ 6,0 & 2,2\end{array}$

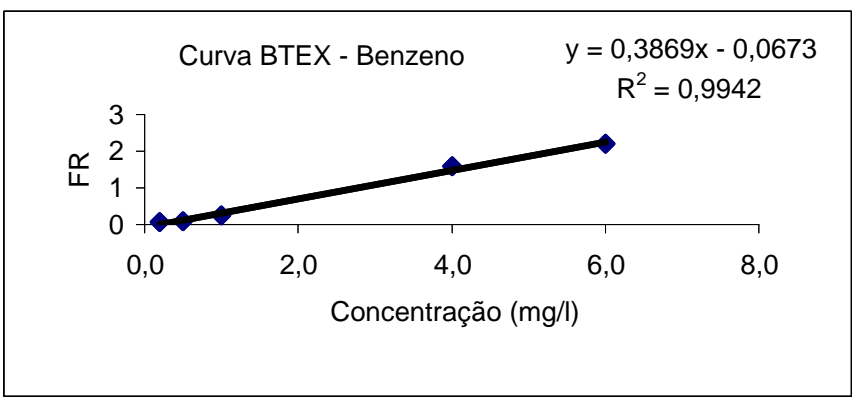

concentração

FR Tolueno

$\begin{array}{ll}0,2 & 0,13 \\ 0,5 & 0,12 \\ 1,0 & 0,25 \\ 4,0 & 1,21 \\ 6,0 & 1,62\end{array}$

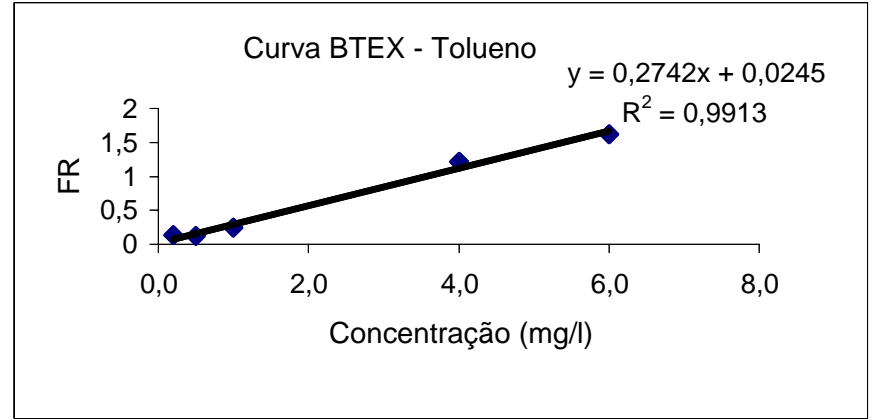

concentração FR Etilbenzeno

$\begin{array}{ll}0,2 & 0,03 \\ 0,5 & 0,09 \\ 1,0 & 0,24 \\ 4,0 & 0,87 \\ 6,0 & 1,21\end{array}$

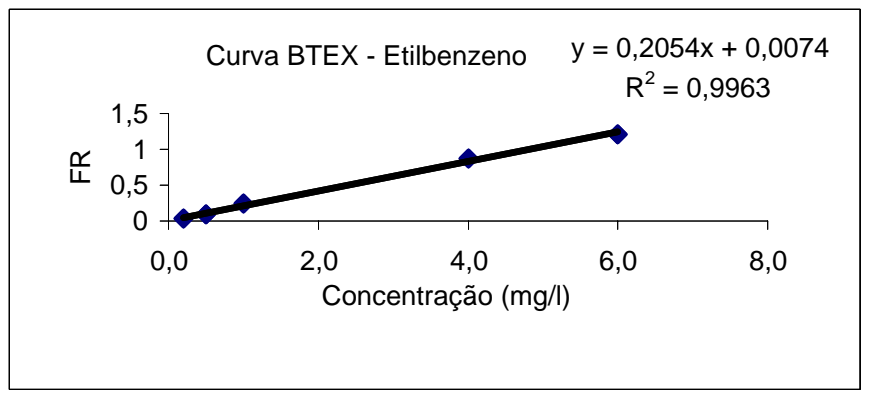

concentração FR mp-xilenos

$\begin{array}{cc}0,4 & 0,06 \\ 1,0 & 0,17 \\ 2,0 & 0,41 \\ 8,0 & 1,66 \\ 12,0 & 2,29\end{array}$

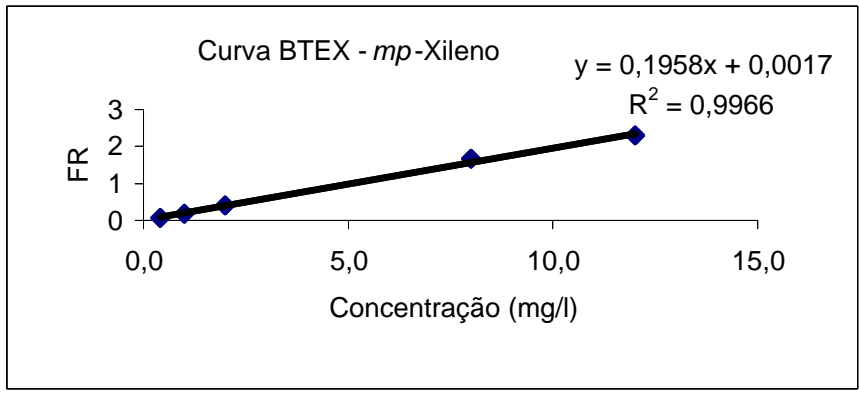

concentração FR o-xileno

$\begin{array}{ll}0,2 & 0,03 \\ 0,5 & 0,08 \\ 1,0 & 0,17 \\ 4,0 & 0,63 \\ 6,0 & 0,87\end{array}$

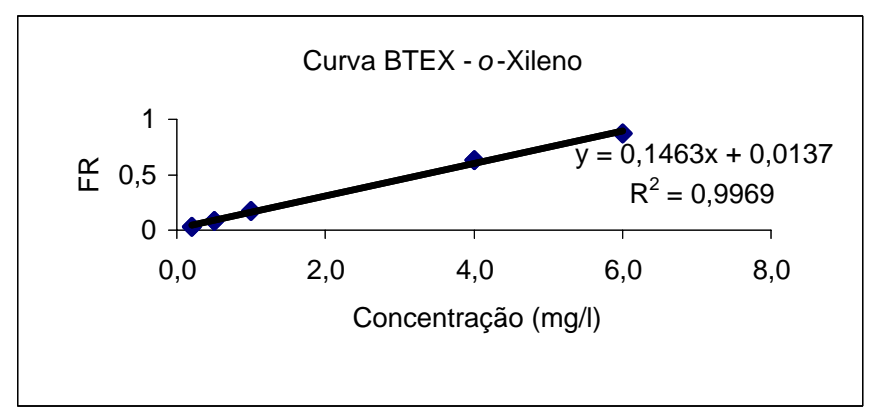




\begin{tabular}{|c|c|c|c|c|c|c|}
\hline conc & clorobz & benzeno & tolueno & etilbz & mp-xileno & o-xileno \\
\hline 0,2 & 14326 & 1045 & 1814 & 421 & 896 & 345 \\
\hline 0,2 & 17478 & 1091 & 2177 & 552 & 1154 & 462 \\
\hline 0,5 & 36830 & 3465 & 5012 & 3485 & 6556 & 2901 \\
\hline 0,5 & 34391 & 3055 & 3862 & 3029 & 5620 & 2538 \\
\hline 1 & 6760 & 1830 & 1822 & 1812 & 2923 & 1178 \\
\hline 1 & 10858 & 2402 & 2525 & 2284 & 4183 & 1757 \\
\hline 2 & 24518 & 11828 & 11773 & 9815 & 20157 & 7769 \\
\hline 2 & 24640 & 11581 & 12360 & 10587 & 20885 & 8484 \\
\hline 4 & 16878 & 21191 & 19087 & 15607 & 29742 & 11300 \\
\hline 4 & 6907 & 13143 & 8887 & 5638 & 10700 & 4031 \\
\hline 6 & 5283 & 14988 & 9575 & 6412 & 12173 & 4593 \\
\hline 6 & 17045 & 27375 & 24318 & 20405 & 38756 & 14702 \\
\hline
\end{tabular}

\begin{tabular}{|c|c|c|c|c|c|}
\hline Conc & \multicolumn{3}{|c|}{ Fator Resposta } & \multicolumn{2}{|c|}{ FR mp-xilenc FR -xileno } \\
\hline 0,2 & 0,07 & 0,13 & 0,03 & 0,06 & 0,02 \\
\hline 0,2 & 0,06 & 0,12 & 0,03 & 0,07 & 0,03 \\
\hline média & 0,07 & 0,13 & 0,03 & 0,06 & 0,03 \\
\hline 0,5 & 0,09 & 0,14 & 0,09 & 0,18 & 0,08 \\
\hline 0,5 & 0,09 & 0,11 & 0,09 & 0,16 & 0,07 \\
\hline média & 0,09 & 0,12 & 0,09 & 0,17 & 0,08 \\
\hline & 0,27 & 0,27 & 0,27 & 0,43 & 0,17 \\
\hline & 0,22 & 0,23 & 0,21 & 0,39 & 0,16 \\
\hline média & 0,25 & 0,25 & 0,24 & 0,41 & 0,17 \\
\hline & 0,48 & 0,48 & 0,40 & 0,82 & 0,32 \\
\hline & 0,47 & 0,50 & 0,43 & 0,85 & 0,34 \\
\hline édia & 0,48 & 0,49 & 0,41 & 0,83 & 0,33 \\
\hline & 1,26 & 1,13 & 0,92 & 1,76 & 0,67 \\
\hline & 1,90 & 1,29 & 0,82 & 1,55 & 0,58 \\
\hline édia & 1,58 & 1,21 & 0,87 & 1,66 & 0,63 \\
\hline & 2,84 & 1,81 & 1,21 & 2,30 & 0,87 \\
\hline & 1,61 & 1,43 & 1,20 & 2,27 & 0,86 \\
\hline édia & 2,22 & 1,62 & 1,21 & 2,29 & 0,87 \\
\hline
\end{tabular}


Curva de calibração para Nitrato $\left(\mathrm{N}-\mathrm{NO}_{3}{ }^{-}\right)$

abs220-2*abs275

0,249333

0,223333

0,205667

0,186333

0,155

0,136667

0,117333

0,093333

0,067

0,044333

0,022

0,025333

0,021667 concentração N-NO3_

1,1

1,0

0,9

0,8

0,7

0,6

0,5

0,4

0,3

0,2

0,1

0,09

0,08

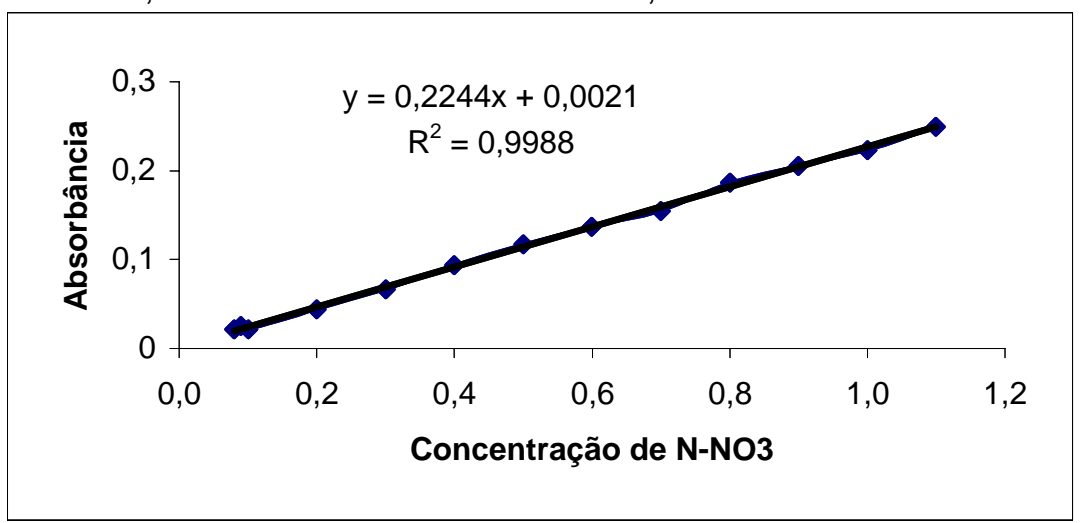

Curva para nitrito N-NO2-

Concentração $\mathrm{N}^{-\mathrm{NO}_{2}}{ }^{-}$Absorbância média

$\begin{array}{lc}0,01 & 0,037 \\ 0,02 & 0,077 \\ 0,06 & 0,234 \\ 0,12 & 0,451 \\ 0,24 & 0,8425 \\ 0,48 & 1,7755\end{array}$

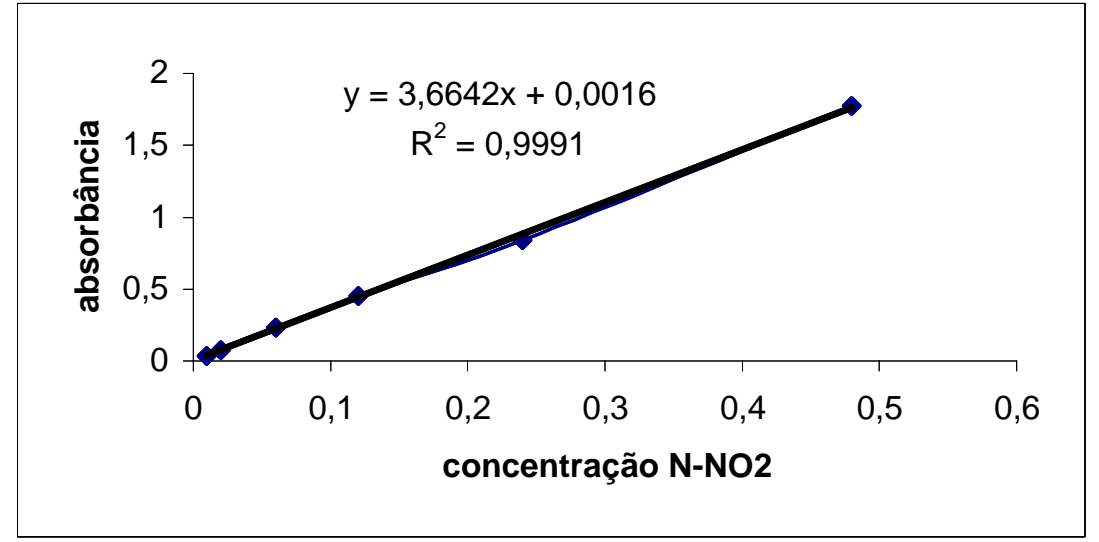


Curva de calibração para amônia - Metodologia FIA

$\mathrm{N}-\mathrm{NH}_{4}{ }^{+} \mathrm{mg} / \mathrm{L}$ absorbância absorbância abs média

$\begin{array}{cccc}10 & 0,106 & 0,106 & 0,106 \\ 25 & 0,29 & 0,287 & 0,2885 \\ 50 & 0,551 & 0,553 & 0,552 \\ 75 & 0,767 & 0,785 & 0,776 \\ 100 & 0,975 & 0,971 & 0,973 \\ 125 & 1,137 & 1,119 & 1,128\end{array}$

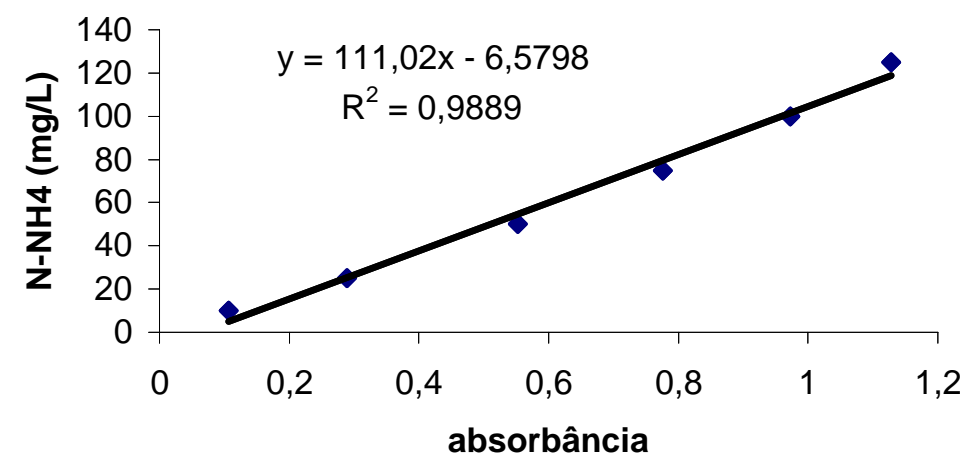




\section{Curva de calibração para óxido nitroso $\left(\mathrm{N}_{2} \mathbf{0}\right)$}

Valores obtidos por cromatografia gasosa.

\begin{tabular}{|c|c|c|c|c|c|}
\hline $\begin{array}{l}\text { Volume de gás } \\
\text { injetado }(\mu \mathrm{l})\end{array}$ & $\begin{array}{c}\text { Volume } \\
\text { de } \mathrm{N}_{2} \mathrm{O}(\mu \mathrm{l})\end{array}$ & $\begin{array}{c}\text { Média do } \\
\text { volume de } \\
\mathrm{N}_{2} \mathrm{O}(\mu \mathrm{l})\end{array}$ & $\begin{array}{c}\text { Volume } \mathrm{N}_{2} \mathrm{O} \\
\qquad(\mu \mathrm{mol})\end{array}$ & $\begin{array}{c}\text { Áreas } \\
\text { cromatográficas }\end{array}$ & $\begin{array}{c}\text { Média } \\
\text { das áreas }\end{array}$ \\
\hline \multirow{3}{*}{10} & 6,8 & \multirow{3}{*}{6,9} & \multirow{3}{*}{0,262} & 8322 & \multirow{3}{*}{8658,667} \\
\hline & 6,9 & & & 8344 & \\
\hline & 7,1 & & & 9310 & \\
\hline \multirow{3}{*}{15} & 11,8 & \multirow{3}{*}{11,00} & \multirow{3}{*}{0,417} & 12692 & \multirow{3}{*}{16947} \\
\hline & 11,8 & & & 19240 & \\
\hline & 9,4 & & & 18918 & \\
\hline \multirow{3}{*}{20} & 15,2 & \multirow{3}{*}{15,2} & \multirow{3}{*}{0,577} & 21149 & \multirow{3}{*}{20751,67} \\
\hline & 15,4 & & & 21263 & \\
\hline & 15,0 & & & 19843 & \\
\hline \multirow{3}{*}{25} & 18,0 & \multirow{3}{*}{19,2} & \multirow{3}{*}{0,729} & 30150 & \multirow{3}{*}{32829,00} \\
\hline & 19,3 & & & 32039 & \\
\hline & 20,3 & & & 36298 & \\
\hline \multirow{3}{*}{40} & 33,7 & \multirow{3}{*}{32,8} & \multirow{3}{*}{1,245} & 45517 & \multirow{3}{*}{45602,33} \\
\hline & 32,6 & & & 45881 & \\
\hline & 32,2 & & & 45409 & \\
\hline \multirow{3}{*}{60} & 43,1 & \multirow{3}{*}{45,4} & \multirow{3}{*}{1,723} & 59383 & \multirow{3}{*}{64972,33} \\
\hline & 43,3 & & & 62703 & \\
\hline & 49,8 & & & 72831 & \\
\hline \multirow{3}{*}{80} & 69,0 & \multirow{3}{*}{67,5} & \multirow{3}{*}{2,561} & 98027 & \multirow{3}{*}{97829,67} \\
\hline & 65,3 & & & 93947 & \\
\hline & 68,2 & & & 101515 & \\
\hline
\end{tabular}

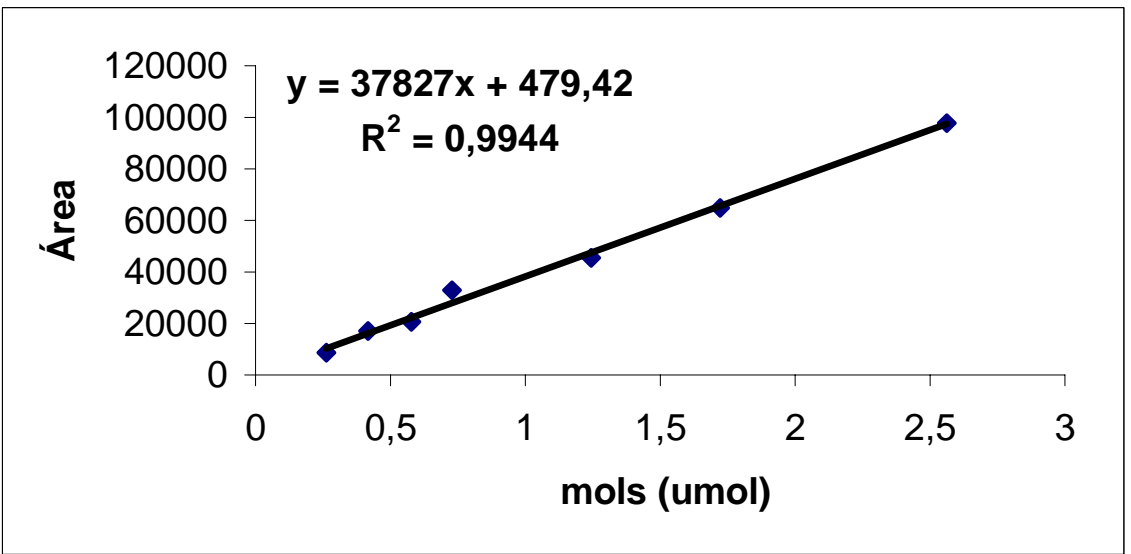




$\begin{array}{ccc}\text { conc }(\mathrm{mg} / \mathrm{L}) & \text { área } & \text { fator resposta } \\ 7,9 & 1,206 & 6,553 \\ 39,5 & 4,834 & 8,171 \\ 79 & 13,208 & 5,981 \\ 474 & 104,06 & 4,555 \\ 632 & 124,69 & 5,069\end{array}$

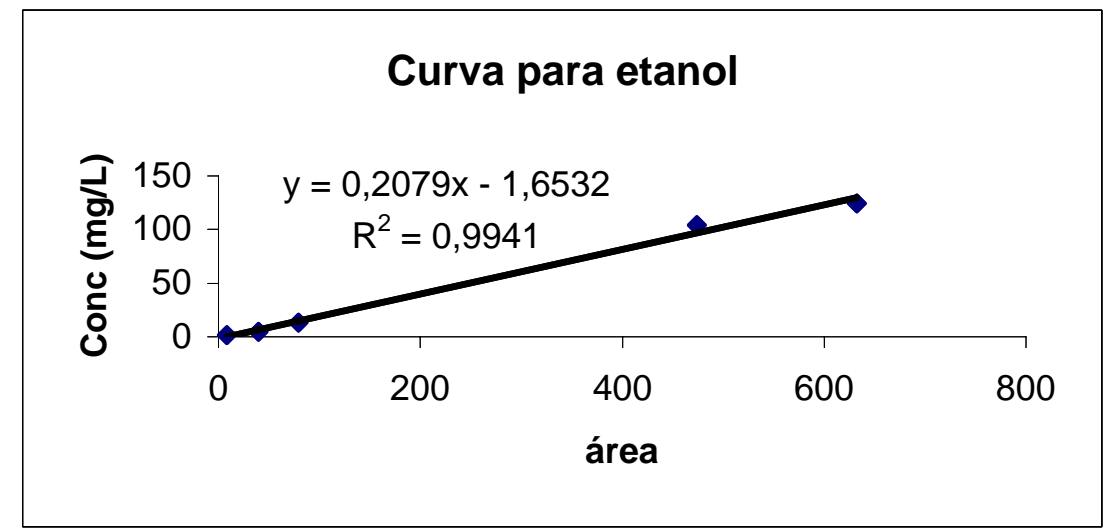

CURVA PARA ÁCIDO ACÉTICO

$\begin{array}{rcr}\text { conc }(\mathrm{mg} / \mathrm{L}) & \text { área } & \text { fator resposta } \\ 6 & 0,91943 & 6,526 \\ 12 & 1,031 & 11,643 \\ 24 & 2,131 & 11,26 \\ 48 & 4,085 & 11,749 \\ 96 & 7,992 & 12,012 \\ 192 & 16,553 & 11,599 \\ 348 & 33,607 & 10,355\end{array}$

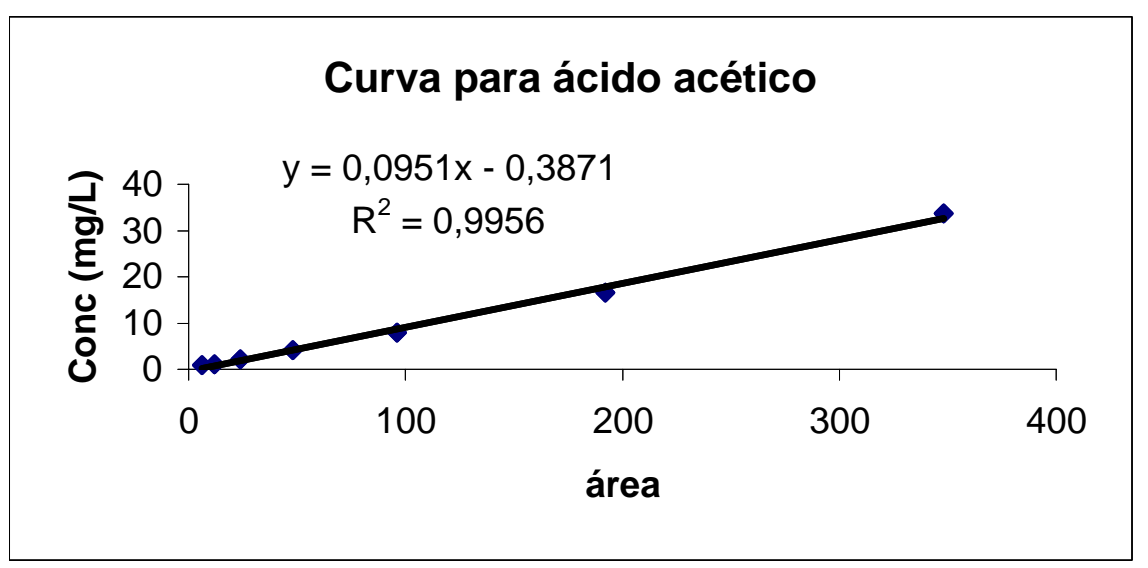


APÊNDICE B - Medidas das concentrações de nitrato - ensaios enriquecimento

Ensaio emaproximadamente 100 horas

Tempo(h) Reatores com meio Zinder

\begin{tabular}{|c|c|c|c|c|c|c|c|c|}
\hline & Reatore & com n & o Zinde & & Reato & com me & olfing & \\
\hline & Z1 & Z2 & Z3 & média & D1 & D2 & D3 & média \\
\hline 0 & 178,4 & 151,3 & 157,6 & 162,4 & 218,4 & 244,3 & 212,4 & 225,0 \\
\hline 10 & 143,5 & 146,1 & 155,7 & 148,4 & 202,9 & 212 & 186,5 & 200,5 \\
\hline 20 & 152 & 140,5 & 140,1 & 144,2 & 212 & 195,6 & 233,9 & 213,8 \\
\hline 30 & 121,5 & 126 & 123,8 & 123,8 & 194,3 & 197,3 & 229,2 & 206,9 \\
\hline 40 & 128,6 & 123,8 & 131,6 & 128,0 & 156,4 & 180,5 & 200,3 & 179,1 \\
\hline 50 & 124,5 & 111,1 & 121,9 & 119,2 & 141,3 & 158,5 & 198,2 & 166,0 \\
\hline 60 & 118,6 & 110 & 113,4 & 114,0 & 98,2 & 117,6 & 115 & 110,3 \\
\hline 70 & 114,8 & 102,6 & 96,3 & 104,6 & 79,6 & 83,5 & 74 & 79,0 \\
\hline 80 & 111,1 & 93,7 & 16,8 & 73,9 & 71,9 & 56,4 & 44,7 & 57,7 \\
\hline 90 & 105,2 & 87,7 & 16,8 & 69,9 & 66,3 & 45,6 & 43 & 51,6 \\
\hline 100 & 26,4 & 41,7 & 0 & 22,7 & 58,1 & 43 & 35,2 & 45,4 \\
\hline 110 & 4,8 & 2,6 & 0 & 2,5 & 27,5 & 43,9 & 38,7 & 36,7 \\
\hline 120 & 4,1 & 1,9 & 0 & 2,0 & & & & \\
\hline
\end{tabular}

Ensaio em aproximadamente 14 horas

\begin{tabular}{rcccc|cccc} 
Tempo (h) Reatores com meio Zinder & & \multicolumn{5}{|c}{ Reatores com meio Dolfing } \\
\\
& Z1 & Z2 & Z3 & média & D1 & D2 & D3 & média \\
0 & 150,5 & 146,1 & 142,7 & 146,4 & 150,5 & 147,9 & 143,1 & 147,2 \\
2 & 145,3 & 146,1 & 146,8 & 146,1 & 152,2 & 150,1 & 155,3 & 152,5 \\
4 & 155 & 137,9 & 142,3 & 145,1 & 142 & 137,5 & 128,6 & 136,0 \\
6 & 142,3 & 120,4 & 129,3 & 130,7 & 128,6 & 128,2 & 94,1 & 117,0 \\
8 & 114,5 & 80,7 & 112,6 & 102,6 & 103 & 104,5 & 63,2 & 90,2 \\
10 & 90 & 27,2 & 42 & 53,1 & 61,4 & 45 & 23,8 & 43,4 \\
12 & 17,5 & 5,2 & 36,8 & 19,8 & 0,8 & 0 & 0 & 0,3 \\
14 & 2,7 & 1,5 & 0,8 & 1,7 & & & &
\end{tabular}


APÊNDICE C - Ensaio do bloqueio pelo acetileno.

Concentração de óxido nitroso no headspace dos reatores batelada

$\begin{array}{ccccc}\text { área } & \text { x (umol) } & \text { headspace } & \mu \mathbf{g} \text { de N-N20 } \mathbf{~ m g ~ d e ~ N - N 2 0 / L ~} \\ \text { Reator1 } & & & & \\ 7513 & 0,19 & 185,94 & 5206,34 & 5,21 \\ 18764 & 0,48 & 483,37 & 13534,47 & 13,53 \\ 31533 & 0,82 & 820,94 & 22986,23 & 22,99 \\ 48518 & 1,27 & 1269,95 & 35558,73 & 35,56 \\ 90179 & 2,37 & 2371,31 & 66396,71 & 66,40 \\ 81921 & 2,15 & 2153,00 & 60284,04 & 60,28 \\ & & & & \\ \text { Reator2 } & & & & \\ 21848 & 0,56 & 564,90 & 15817,28 & 15,82 \\ 37347 & 0,97 & 974,64 & 27289,83 & 27,29 \\ 60993 & 1,60 & 1599,75 & 44792,88 & 44,79 \\ 97036 & 2,55 & 2552,58 & 71472,34 & 71,47 \\ 105274 & 2,77 & 2770,36 & 77570,21 & 77,57 \\ & & & & \\ \text { Reator3 } & & & & \\ 14385 & 0,37 & 367,61 & 10293,08 & 10,29 \\ 28561 & 0,74 & 742,37 & 20786,32 & 20,79 \\ 49091 & 1,29 & 1285,10 & 35982,88 & 35,98 \\ 82132 & 2,16 & 2158,58 & 60440,22 & 60,44 \\ 107795 & 2,84 & 2837,01 & 79436,28 & 79,44 \\ 84710 & 2,23 & 2226,73 & 62348,49 & 62,35 \\ & & & & \\ \text { Reator4 } & & & & 4,75 \\ 6903 & 0,17 & 169,81 & 4754,81 & 40,02 \\ 14014 & 0,36 & 357,80 & 10018,46 & 10,02 \\ 27820 & 0,72 & 722,78 & 20237,83 & 20,24 \\ 53945 & 1,41 & 1413,42 & 39575,86 & 39,58 \\ 86926 & 2,29 & 2285,31 & 63988,80 & 63,99 \\ 95850 & 2,52 & 2521,23 & 70594,45 & 70,59\end{array}$





\section{APÊNDICE D - Medida da concentração de amônia}

\section{Ensaio para verificar a concentração de amônia no lodo}

Quadro 5 - Concentração de amônia no lodo (inóculo)

\begin{tabular}{|l|l|l|}
\hline & Valor medido na titulação & Concentração (mg/L) \\
\hline Meio de cultivo & 2,17 & 27,1 \\
\hline Lodo lavado & 0,34 & 255,4 \\
\hline Lodo sem lavar & 0,56 & 551,0 \\
\hline
\end{tabular}

OBS: valor da titulação do branco: $0,15 \mathrm{~mL}$

Quadro 6 - Concentração de amônia inicial e final no ensaio em batelada

\begin{tabular}{|c|c|c|c|}
\hline Reator & $\mathrm{N}-\mathrm{NH}_{4}{ }^{+}$inicial & $\mathrm{N}-\mathrm{NH}_{4}^{+}$final & $\begin{array}{l}\text { Normalidade }=0,096 \\
\text { Diluicã }=10\end{array}$ \\
\hline Reator 1 & 0,56 & Erro na destilação & Valor do branco $=0,15$ \\
\hline Reator 2 & 0,60 & 0,31 & \\
\hline média & 0,58 & & \\
\hline
\end{tabular}

$\mathrm{N}-\mathrm{NH}_{4}{ }^{+}=($Vol. titulado - Vol. titulação do branco $) \mathrm{X}$ Normalidade do ácido X 14000 Vol da amostra destilada $(\mathrm{mL})$

N-NH ${ }_{4}^{+}$INICIAL $=\frac{(0,58-0,15) X 0,096 \times 14000}{100} \times 10=\mathbf{5 7 , 8} \mathbf{~ m g} / \mathbf{L}$

$\mathbf{N}-\mathbf{N H}_{4}{ }^{+}$FINAL $=(\underline{0,31-0,15) \times 0,096 \times 14000} \times 10=\mathbf{2 1 , 5} \mathbf{~ m g} / \mathbf{L}$ 100 
APÊNDICE E - Valores das absorbâncias medidas nos ensaios de caracterização nutricional, das culturas purificadas em presença de benzeno e etilbenzeno, sob condições desnitrificantes e fermentativas.

Quadro 7 - Absorbâncias medidas nos ensaios de caracterização nutricional

\begin{tabular}{|l|c|c|c|c|}
\hline \multicolumn{1}{|c|}{ Substratos } & \multicolumn{2}{|c|}{ Cultura isolada em benzeno } & \multicolumn{2}{c|}{ Cultura isolada em etilbenzeno } \\
\hline & \multicolumn{2}{c}{ Absorbância sob condição } & \multicolumn{2}{c|}{ Absorbância sob condição } \\
& Desnitrificante & Fermentativa & Desnitrificante & Fermentativa \\
\hline inóculo & 0,025 & 0,03 & 0,021 & 0,021 \\
\hline etanol & 0,354 & 0,112 & 0,138 & 0,124 \\
\hline lactato & 0,604 & 0,101 & 0,289 & 0,182 \\
\hline glicose & 0,432 & 0,084 & 0,247 & 0,147 \\
\hline propionato & 0,336 & 0,108 & 0,137 & 0,093 \\
\hline butirato & 0,107 & 0,058 & 0,098 & 0,088 \\
\hline piruvato & 0,179 & 0,128 & 0,066 & 0,053 \\
\hline benzeno & 0,296 & 0,105 & 0,212 & 0,139 \\
\hline tolueno & 0,248 & 0,07 & 0,248 & 0,157 \\
\hline etilbenzeno & 0,289 & 0,087 & 0,258 & 0,172 \\
\hline p-xileno & 0,216 & 0,067 & 0,125 & 0,09 \\
\hline acetato & 0,221 & 0,099 & 0,04 & 0,041 \\
\hline benzoato & 0,053 & 0,041 & 0,082 & 0,085 \\
\hline fenol & 0,018 & 0,021 & 0,02 & 0,026 \\
\hline metanol & 0,027 & 0,022 & 0,014 & 0,021 \\
\hline
\end{tabular}

$<0,035$ não ocorreu crescimento; 0,036 - 0,20 crescimento moderado; 0,201 - 0,400 crescimento bom; $\geq 0,401$ crescimento ótimo. 


\section{APÊNDICE F - Medidas da absorbância e concentração de nitrato e etanol nos ensaios de crescimento das culturas purificadas. Reatores batelada}

Quadro 8 - Valores das absorbâncias, concentrações de nitrato e etanol, medidos no ensaio de crescimento celular, para a cultura isolada em presença de etilbenzeno.

\begin{tabular}{|c|c|c|c|c|c|c|c|c|c|}
\hline & \multicolumn{9}{|c|}{ Cultura purificada em etilbenzeno } \\
\hline $\begin{array}{c}\text { Tempo } \\
\text { (h) }\end{array}$ & $\begin{array}{c}\text { Reator } \\
\text { Nitrato (N-N }{ }_{3}{ }^{-} \text {) }\end{array}$ & $\begin{array}{c}\text { Reator } \\
2\end{array}$ & Média & $\begin{array}{c}\text { Reator } \\
1\end{array}$ & $\begin{array}{c}\text { Reator } \\
2\end{array}$ & Média & $\begin{array}{c}\text { Reator } \\
1\end{array}$ & $\begin{array}{c}\text { Reator } \\
2\end{array}$ & Média \\
\hline 0 & 347,4 & 360,7 & 354,0 & 0,011 & 0,016 & 0,01 & 339,8 & 256,0 & 297,9 \\
\hline 11,5 & 367,4 & 389,7 & 378,5 & 0,103 & 0,143 & 0,12 & & & \\
\hline 14,5 & 293,9 & 316,1 & 304,9 & 0,129 & 0,174 & 0,15 & & & \\
\hline 18,5 & 222,9 & 256 & 239,3 & 0,171 & 0,234 & 0,20 & 214,4 & 178,1 & 196,2 \\
\hline 22,5 & 191,9 & 215,9 & 203,6 & 0,215 & 0,271 & 0,24 & & & \\
\hline 27 & 206,9 & 222,5 & 214,7 & 0,301 & 0,358 & 0,33 & & & \\
\hline 33 & 215,9 & 262,7 & 239,3 & 0,456 & 0,443 & 0,45 & & & \\
\hline 40,5 & 175,8 & 235 & 205,4 & 0,472 & 0,473 & 0,47 & & & \\
\hline 60 & 157,9 & 149 & 153,5 & 0,491 & 0,425 & 0,46 & & & \\
\hline 90 & 97,1 & 98,8 & 97,9 & 0,368 & 0,365 & 0,37 & & & \\
\hline 112 & 83,3 & 91,7 & 87,5 & & & & & & \\
\hline 136 & 65,9 & 74,8 & 70,3 & & & & & & \\
\hline 200 & 60,6 & 57 & 58,8 & & & & 0,0 & 0,0 & \\
\hline
\end{tabular}

Quadro 9 - Valores das absorbâncias, concentrações de nitrato $\left(\mathrm{N}^{-\mathrm{NO}_{3}}{ }^{-}\right)$e etanol, medidos no ensaio de crescimento celular, para a cultura isolada em presença de benzeno, nos reatores batelada contendo benzeno, nitrato e etanol.

\begin{tabular}{|c|r|r|r|r|r|r|r|r|r|}
\hline \multicolumn{10}{|c|}{ Cultura purificada em benzeno } \\
\hline & \multicolumn{9}{|c|}{ Nitrato (N-NO ${ }_{3}^{-}$) } \\
\hline $\begin{array}{c}\text { Tempo } \\
\text { (h) }\end{array}$ & Rator1 & $\begin{array}{c}\text { Reator } \\
2\end{array}$ & Média & $\begin{array}{c}\text { Reator } \\
1\end{array}$ & $\begin{array}{c}\text { Reator } \\
2\end{array}$ & Média & $\begin{array}{c}\text { Reator } \\
1\end{array}$ & $\begin{array}{c}\text { Reator } \\
2\end{array}$ & Média \\
\hline 0 & 380,8 & 405,3 & 393,0 & 0,029 & 0,022 & 0,0255 & 326,0 & 265,7 & 295,8 \\
\hline 11,5 & 432,0 & 376,3 & 404,2 & 0,168 & 0,112 & 0,14 & & & \\
\hline 14,5 & 298,3 & 329,5 & 313,9 & 0,21 & 0,155 & 0,1825 & & & \\
\hline 18,5 & 307,3 & 329,5 & 318,4 & 0,277 & 0,18 & 0,2285 & 189,9 & 128,7 & 159,3 \\
\hline 22,5 & 247,1 & 269 & 258,1 & 0,287 & 0,231 & 0,259 & & & \\
\hline 27 & 218,1 & 233,7 & 225,9 & 0,407 & 0,308 & 0,3575 & & & \\
\hline 33 & 211,4 & 242,6 & 227,0 & 0,467 & 0,443 & 0,455 & & & \\
\hline 40,5 & 182,5 & 220,3 & 201,4 & 0,556 & 0,48 & 0,518 & & & \\
\hline 60 & 135,7 & 153,5 & 144,6 & 0,448 & 0,452 & 0,45 & & & \\
\hline 90 & 108,7 & 123,8 & 116,2 & 0,387 & 0,352 & 0,3695 & & & \\
\hline 112 & 96,2 & 117,1 & 106,7 & & & & & & \\
\hline 136 & 69,8 & 101,6 & 85,5 & & & & & & \\
\hline 200 & 47,6 & 97,1 & 72,4 & & & & 1,8 & 1,7 & 1,8 \\
\hline
\end{tabular}




\section{APÊNDICE G - Valores das absorbâncias medidas para obtenção do tempo de geração das culturas purificadas. Reatores em batelada}

Quadro 10 - Valores das absorbâncias e concentrações de nitrato $\left(\mathrm{N}^{-\mathrm{NO}_{3}}{ }^{-}\right)$, medidos no ensaio de crescimento celular, para a cultura isolada em presença de etilbenzeno nos reatores contendo somente nitrato e etanol.

\begin{tabular}{|c|r|r|r|r|r|r|}
\hline & \multicolumn{6}{|c|}{ Célula isolada em etilbenzeno } \\
\hline $\begin{array}{c}\text { Tempo } \\
\text { (h) }\end{array}$ & Reator 1 & Reator 2 & \multicolumn{1}{|c|}{ Média } & Reator 1 & \multicolumn{1}{|c|}{ Reator 2 } & Média \\
\hline 0 & 360,7 & 340,7 & 350,7 & 0,015 & 0,028 & 0,02 \\
\hline 11,5 & 418,7 & 412,0 & 415,3 & 0,101 & 0,105 & 0,10 \\
\hline 14,5 & 327,3 & 307,3 & 317,3 & 0,141 & 0,145 & 0,14 \\
\hline 18,5 & 351,8 & 345,1 & 348,5 & 0,164 & 0,167 & 0,17 \\
\hline 22,5 & 282,8 & 267,1 & 274,9 & 0,22 & 0,225 & 0,22 \\
\hline 27 & 262,7 & 236,0 & 249,4 & 0,28 & 0,293 & 0,29 \\
\hline 33 & 253,8 & 258,2 & 256,0 & 0,421 & 0,39 & 0,41 \\
\hline 40,5 & 242,6 & 229,3 & 236,0 & 0,47 & 0,476 & 0,47 \\
\hline 60 & 140,2 & 137,9 & 139,0 & 0,451 & 0,551 & 0,50 \\
\hline 90 & 52,5 & 44,1 & 48,3 & 0,41 & 0,445 & 0,43 \\
\hline 112 & 37,8 & 33,8 & 35,8 & & & \\
\hline 136 & 27,6 & 20,9 & 24,2 & & & \\
\hline 200 & 12,4 & 10,2 & 11,3 & & & \\
\hline
\end{tabular}

Quadro 11 - Valores das absorbâncias e concentrações de nitrato $\left(\mathrm{N}^{-} \mathrm{NO}_{3}{ }^{-}\right)$, medidos no ensaio de crescimento celular, para a cultura isolada em presença de benzeno nos reatores contendo somente nitrato e etanol.

\begin{tabular}{|c|r|r|r|r|r|r|}
\hline & \multicolumn{7}{|c|}{ Cultura isolada em benzeno } \\
\hline & \multicolumn{3}{|c|}{ Nitrato (N-NO ${ }^{-}$) } & \multicolumn{3}{|c|}{ Absorbância } \\
\hline $\begin{array}{c}\text { Tempo } \\
\text { (h) }\end{array}$ & Reator 1 & Reator 2 & \multicolumn{1}{|c|}{ Média } & Reator 1 & \multicolumn{1}{c|}{ Reator 2 } & Média \\
\hline 0 & 374,1 & 383 & 378,6 & 0,02 & 0,03 & 0,03 \\
\hline 11,5 & 391,9 & 360,7 & 376,3 & 0,13 & 0,14 & 0,14 \\
\hline 14,5 & 309,5 & 316,2 & 312,8 & 0,17 & 0,20 & 0,19 \\
\hline 18,5 & 296,1 & 311,7 & 303,9 & 0,26 & 0,30 & 0,28 \\
\hline 22,5 & 236,0 & 238,2 & 237,1 & 0,35 & 0,34 & 0,35 \\
\hline 27 & 220,4 & 218,1 & 219,2 & 0,43 & 0,44 & 0,43 \\
\hline 33 & 229,3 & 229,3 & 229,3 & 0,43 & 0,45 & 0,44 \\
\hline 40,5 & 202,5 & 213,7 & 208,1 & 0,50 & 0,49 & 0,49 \\
\hline 60 & 126,8 & 166,9 & 146,8 & 0,48 & 0,50 & 0,49 \\
\hline 90 & 72,6 & 117,2 & 94,9 & 0,39 & 0,44 & 0,42 \\
\hline 112 & 67,7 & 114,9 & 91,3 & & & \\
\hline 136 & 34,7 & 106 & 70,4 & & & \\
\hline 200 & 30,3 & 97,1 & 63,7 & & & \\
\hline
\end{tabular}




\section{APÊNDICE H - Medidas dos parâmetros de monitoramento dos reatores RAHLF1 e RAHLF2.}

Quadro 12 - Valores das medidas dos parâmetros de monitoramento obtidos no afluente e efluente do reator RAHLF1, durante o período de operação.

\begin{tabular}{|c|c|c|c|c|c|c|c|c|c|c|c|c|}
\hline Alimentação & $\begin{array}{c}\mathrm{DQO}_{\mathrm{B}} \\
\mathrm{AF}\end{array}$ & $\begin{array}{c}\mathrm{DQO}_{\mathrm{B}} \\
\mathrm{EF}\end{array}$ & $\begin{array}{c}\mathrm{DQO}_{\mathrm{F}} \\
\mathrm{AF}\end{array}$ & $\begin{array}{c}\mathrm{DQO}_{\mathrm{F}} \\
\mathrm{EF}\end{array}$ & $\begin{array}{c}\mathrm{NO}_{3}^{-} \\
\mathrm{AF}\end{array}$ & $\begin{array}{c}\mathrm{NO}_{3}{ }^{-} \\
\mathrm{EF}\end{array}$ & $\begin{array}{c}\mathrm{NO}_{2}{ }^{-} \\
\mathrm{AF}\end{array}$ & $\begin{array}{c}\mathrm{NO}_{2}^{-} \\
\mathrm{EF}\end{array}$ & $\begin{array}{c}\text { SSV } \\
\text { AF }\end{array}$ & $\begin{array}{c}\text { SSV } \\
\text { EF }\end{array}$ & $\begin{array}{l}\mathrm{pH} \\
\mathrm{AF}\end{array}$ & $\begin{array}{l}\mathrm{pH} \\
\mathrm{EF}\end{array}$ \\
\hline Benzeno & 908,0 & 115,7 & 918,0 & 98,2 & 352,6 & 119,4 & 0,08 & 62,2 & 11,0 & 35,0 & 7,3 & 9,1 \\
\hline Benzeno & 977,7 & 259,1 & 911,9 & 162,5 & 352,6 & 121,6 & 0,0 & 82,2 & 13,0 & 35,0 & 7,2 & 9,2 \\
\hline Benzeno & 877,5 & 138,2 & 823,5 & 10,7 & 348,5 & 57,9 & 0,08 & 43,9 & 10,0 & 46,0 & 7,0 & 9,5 \\
\hline Benzeno & 915,1 & 131,2 & 905,7 & 86,6 & 364,1 & 14,0 & 0,04 & 4,6 & 12,0 & 33,0 & 7,0 & 9,6 \\
\hline Benzeno & 898,6 & 107,2 & 854,0 & 73,7 & 355,2 & 74,4 & - & - & 10,0 & 40,0 & 7,3 & 7,3 \\
\hline Benzeno & 869,0 & 92,4 & 858,7 & 67,8 & 367,4 & 6,4 & 0,0 & 0,08 & 10,0 & 45,0 & 7,2 & 8,7 \\
\hline Benzeno & 877,5 & 97,1 & 886,9 & 80,7 & 358,5 & 1,7 & 0,08 & 38,5 & 11,0 & 28,0 & 7,0 & 9,0 \\
\hline Benzeno & 879,9 & 59,6 & 849,3 & 31,4 & 351,8 & 0,85 & 0,034 & 0,01 & 15,0 & 22,0 & - & - \\
\hline Benzeno & 1258,1 & 102,6 & 1213,8 & 86,2 & 581,0 & 564,0 & 0,115 & 48,0 & 10,0 & 52,0 & 7,5 & 8,5 \\
\hline Benzeno & 1237,7 & 64,1 & 1220,2 & 53,6 & 554,6 & 30,2 & 0,5 & 13,5 & 47,0 & 58,0 & - & - \\
\hline Tolueno & 1328,2 & 96,2 & 1264,1 & 72,9 & 502,2 & 20,0 & 11,0 & 0,0 & 61,0 & 18,0 & 7,1 & 9,0 \\
\hline Tolueno & 1281,6 & 48,1 & 1136,0 & 35,0 & 622,5 & 61,0 & - & - & 37,0 & 46,0 & 7,5 & 9,7 \\
\hline Tolueno & 1316,5 & 48,1 & 1246,6 & 29,2 & 539,0 & 0,0 & - & - & 62,0 & 70,0 & 7,0 & 8,6 \\
\hline Tolueno & 914,8 & 10,3 & 838,9 & 0,0 & 526,7 & 127,0 & 0,0 & 5,5 & 21,0 & 65,0 & - & - \\
\hline m-xileno & 1322,3 & 65,6 & 1269,9 & 46,7 & 479,9 & 62,0 & - & - & 58,0 & 47,0 & 7,2 & 9,0 \\
\hline m-xileno & 1287,4 & 65,6 & 1264,1 & 53,9 & 527,8 & 4,0 & - & - & 45,0 & 68,0 & 7,2 & 8,9 \\
\hline m-xileno & 1252,4 & 300,0 & 1252,4 & 262,1 & 439,0 & 5,0 & 0,0 & 0,0 & 40,0 & 50,0 & - & - \\
\hline Etilbenzeno & 1526,2 & 278,2 & 1561,1 & 228,7 & 497,8 & 5,1 & - & - & 21,0 & 27,0 & 7,5 & 8,9 \\
\hline Etilbenzeno & 1526,2 & 272,3 & 1532,0 & 300,6 & 538,9 & 4,4 & - & - & 70,0 & 78,0 & 7,4 & 8,9 \\
\hline Etilbenzeno & 1438,8 & 305,8 & 1409,7 & 273,8 & 507,8 & 2,8 & 0,0 & 0,0 & 62,0 & 77,0 & - & - \\
\hline BTEX & 1957,1 & 461,6 & 1782,4 & 419,4 & 475,5 & 4,9 & - & - & 35,0 & 47,0 & 7,7 & 9,0 \\
\hline BTEX & 2027,0 & 603,5 & 1893,1 & 582,5 & 417,5 & 3,1 & 0,35 & 0,0 & 33,0 & 36,0 & - & - \\
\hline
\end{tabular}


Quadro 13 - Valores das medidas dos parâmetros de monitoramento obtidos no afluente e efluente do reator RAHLF2, durante o período de operação.

\begin{tabular}{|c|c|c|c|c|c|c|c|c|c|c|c|c|}
\hline Alimentação & $\begin{array}{c}\mathrm{DQO}_{\mathrm{B}} \\
\mathrm{AF}\end{array}$ & $\begin{array}{c}\mathrm{DQO}_{\mathrm{B}} \\
\mathrm{EF}\end{array}$ & $\begin{array}{c}\mathrm{DQO}_{\mathrm{F}} \\
\mathrm{AF}\end{array}$ & $\begin{array}{c}\mathrm{DQO}_{\mathrm{F}} \\
\mathrm{EF}\end{array}$ & $\begin{array}{c}\mathrm{NO}_{3}^{-} \\
\mathrm{AF}\end{array}$ & $\begin{array}{c}\mathrm{NO}_{3}^{-} \\
\mathrm{EF}\end{array}$ & $\begin{array}{c}\mathrm{NO}_{2}^{-} \\
\mathrm{AF}\end{array}$ & $\begin{array}{c}\mathrm{NO}_{2}^{-} \\
\mathrm{EF}\end{array}$ & $\begin{array}{c}\text { SSV } \\
\text { AF }\end{array}$ & $\begin{array}{c}\text { SSV } \\
\text { EF }\end{array}$ & $\begin{array}{l}\mathrm{pH} \\
\mathrm{AF}\end{array}$ & $\begin{array}{l}\mathrm{pH} \\
\mathrm{EF}\end{array}$ \\
\hline Etilbenzeno & 978,0 & 165,5 & 1073,0 & 125,5 & 329,5 & 60,6 & 0,08 & 12,7 & 19,0 & 5,0 & 7,3 & 8,7 \\
\hline Etilbenzeno & 1031,3 & 219,8 & 1006,3 & 196,5 & 365,9 & 52,5 & 0,08 & 23,6 & 39,0 & 47,0 & 7,3 & 8,9 \\
\hline Etilbenzeno & 955,0 & 129,6 & 915,1 & 84,2 & 325,8 & 167,2 & 0,08 & 21,4 & 19,0 & 43,0 & 7,0 & 8,7 \\
\hline Etilbenzeno & 879,9 & 85,4 & 832,9 & 36,1 & 349,6 & 11,5 & 0,08 & 0,78 & 17,0 & 27,0 & 6,9 & 8,8 \\
\hline Etilbenzeno & 882,2 & 74,8 & 929,2 & 70,1 & 377,4 & 14,9 & 0,06 & 8,3 & 7,0 & 18,0 & 7,2 & 9,4 \\
\hline Etilbenzeno & 884,6 & 83,0 & 854,0 & 53,7 & 361,0 & 40,3 & 0,08 & 20,7 & 24,0 & 8,0 & - & - \\
\hline Etilbenzeno & 851,7 & 94,8 & 854,0 & 20,8 & 357,4 & 32,0 & 0,0 & 0,08 & 16,0 & 57,0 & 7,2 & 8,2 \\
\hline Etilbenzeno & 882,2 & 84,2 & 870,5 & 56,0 & 387,5 & 39,8 & 0,08 & 17,3 & 12,0 & 34,0 & 7,0 & 8,3 \\
\hline Etilbenzeno & 832,9 & 51,4 & 809,4 & 42,0 & 355,2 & 8,0 & 0,06 & 5,5 & 24,0 & 35,0 & - & - \\
\hline Etilbenzeno & 1253,4 & 56,0 & 1169,5 & 43,2 & 534,9 & 39,4 & 0,13 & 12,5 & 44,0 & 52,0 & 7,5 & 8,9 \\
\hline Etilbenzeno & 1252,3 & 53,6 & 1205,7 & 38,5 & 547,9 & 15,5 & 0,5 & 2,2 & 24,0 & 40,0 & - & - \\
\hline Tolueno & 1403,9 & 256,3 & 1222,3 & 182,1 & 624,8 & 219,0 & - & - & 10,0 & 60,0 & 7,4 & 8,9 \\
\hline Tolueno & 1683,4 & 308,7 & 1328,2 & 118,0 & 545,7 & 12,9 & - & - & 16,0 & 42,0 & 7,0 & 8,3 \\
\hline Tolueno & 891,3 & 203,9 & 710,8 & 179,2 & 534,5 & 103,1 & 0,0 & 79,2 & 29,0 & 46,0 & - & - \\
\hline Tolueno & 1334,0 & 214,1 & 1351,4 & 171,9 & 496,6 & 7,7 & - & - & - & - & 7,2 & 9,3 \\
\hline Tolueno & 1287,4 & 350,9 & 1194,2 & 307,2 & 473,3 & 6,8 & - & - & - & - & 7,2 & 9,1 \\
\hline Tolueno & 1258,3 & 406,3 & 1240,8 & 345,1 & 451,4 & 6,1 & 0,0 & 0,0 & 49,0 & 54,0 & - & - \\
\hline m-xileno & 1467,6 & 516,9 & 1444,9 & 345,1 & 510,0 & 7,5 & - & - & 80,0 & 86,0 & 7,5 & 9,7 \\
\hline m-xileno & 1586,3 & 524,2 & 1566,9 & 537,3 & 542,3 & 8,0 & - & - & 55,0 & 100,0 & 7,2 & 8,7 \\
\hline m-xileno & 1526,2 & 524,2 & 1473,7 & 413,6 & 534,5 & 39,6 & 0,0 & 0,0 & 55,0 & 100,0 & - & - \\
\hline m-xileno & 1654,3 & 596,5 & 1619,3 & 521,9 & 417,5 & 4,3 & 0,12 & 0,0 & 117,0 & 22,0 & - & - \\
\hline Benzeno & 1322,5 & 209,7 & 1270,0 & 128,2 & 524,5 & 11,5 & 0,02 & 0,0 & 26,0 & 66,0 & - & - \\
\hline Benzeno & 1310,7 & 190,8 & 1322,3 & 142,8 & 510,0 & 2,0 & 0,0 & 0,0 & 4,0 & 7,0 & - & - \\
\hline o-xileno & 1299,0 & 250,5 & 1258,5 & 163,2 & 516,7 & 11,5 & 0,03 & 0,0 & 24,0 & 34,0 & - & - \\
\hline p-xileno & 1607,7 & 286,9 & 1648,5 & 208,3 & 510,0 & 28,2 & 0,0 & 0,2 & 22,0 & 25,0 & - & - \\
\hline BTEX & 1596,8 & 257,4 & 1642,5 & 169,4 & 574,6 & 85,1 & 0,5 & 64,1 & 14,0 & 49,0 & - & - \\
\hline
\end{tabular}




\section{APÊNDICE I}

Perfis de concentração dos hidrocarbonetos. Reatores RAHLF1 e RAHLF2 
Perfil RAHLF1 - alimentação com tolueno

$\begin{array}{ccccccc}\text { L/D } & \text { área Tolueno } & \text { área Clbz } & \text { FR } & \text { média FR } & \text { conc }(\mathrm{mg} / \mathrm{l}) & \text { curva } \\ \text { entrada } & 88566 & 18022 & 4,9 & 5,130 & 30,8 & \text { curva alta } \\ \text { entrada } & 140501 & 26284 & 5,3 & & & \\ & & & & & & \\ 4 & 15971 & 10633 & 1,5 & 1,319 & 9,0 & \text { curva alta } \\ 4 & 23678 & 20854 & 1,1 & & & \\ 8 & 15341 & 14017 & 1,1 & 0,966 & 2,9 & \text { curva baixa } \\ 8 & 21823 & 26067 & 0,8 & & & \\ 12 & 11740 & 26305 & 0,4 & 0,444 & 1,4 & \text { curva baixa } \\ 12 & 11582 & 26252 & 0,4 & & & \\ 20 & 1739 & 26657 & 0,1 & 0,064 & 0,2 & \text { curva baixa } \\ 20 & 1591 & 25045 & 0,1 & & & \\ & & & & & & \\ \text { saída } & 0 & 25756 & 0,0 & 0,000 & 0,0 & \text { curva baixa } \\ \text { saída } & 0 & 26286 & 0,0 & & & \end{array}$

Perfil RAHLF 1 - alimentação com m-xileno

\begin{tabular}{|c|c|c|c|c|c|c|}
\hline $\mathrm{L} / \mathrm{D}$ & área m- xileno & área Clbz & F R & média FR & conc $(\mathrm{mg} / \mathrm{L})$ & curva \\
\hline entrada & 83388 & 30422 & 2,741 & 2,7 & 32,1 & curva alta \\
\hline entrada & 68222 & 25219 & 2,705 & & & \\
\hline 4 & 10276 & 33975 & 0,302 & 0,3 & 4,3 & Curva baixa \\
\hline 4 & & & & & & \\
\hline 8 & 8109 & 32339 & 0,251 & 0,3 & 1,7 & Curva baixa \\
\hline 8 & 8472 & 32695 & 0,259 & & & \\
\hline 12 & 4395 & 31949 & 0,138 & 0,1 & 0,4 & Curva baixa \\
\hline 12 & & & & & & \\
\hline 16 & 2628 & 32314 & 0,081 & 0,1 & 0,5 & Curva baixa \\
\hline 16 & 2974 & 38395 & 0,077 & & & \\
\hline 20 & 0 & 27341 & 0,000 & 0,02 & 0,0 & Curva baixa \\
\hline 20 & 1179 & 37010 & 0,032 & & & \\
\hline saida & 0 & 31833 & 0,000 & 0,0 & 0,0 & Curva baixa \\
\hline saida & 0 & 32980 & 0,000 & & & \\
\hline
\end{tabular}


Perfil RAHLF1 - alimentação com etilbenzeno

$\begin{array}{crrrrrr}\text { L/D } & \text { área etilbz } & \text { área Clbz } & \text { FR } & \text { média FR } & \text { conc }(\mathrm{mg} / \mathrm{L}) & \text { curva } \\ \text { entrada } & 21347 & 7260 & 2,94 & 2,94 & 33,3 & \text { curva alta } \\ \text { entrada } & 20829 & 7085 & 2,94 & & & \\ & & & & & & \\ 4 & 6386 & 25598 & 0,25 & 0,28 & 2,9 & \text { curva alta } \\ 4 & 4350 & 14281 & 0,30 & & & \\ & & & & & & \\ 8 & 5436 & 24724 & 0,22 & 0,23 & 2,3 & \text { curva alta } \\ 8 & 5860 & 24812 & 0,24 & & & \\ 12 & 8002 & 36299 & 0,22 & 0,20 & 1,1 & \text { curva baixa } \\ 12 & 5131 & 27284 & 0,19 & & & \\ 16 & 3229 & 26430 & 0,12 & 0,12 & 0,7 & \text { curva baixa } \\ 16 & 3960 & 31958 & 0,12 & & & \\ & & & & & & \\ \text { saida } & 1175 & 20358 & 0,06 & 0,06 & 0,4 & \text { curva baixa } \\ \text { saida } & 1348 & 23961 & 0,06 & & & \end{array}$


L/D

\begin{tabular}{|c|c|c|c|c|c|c|c|c|}
\hline \multirow{5}{*}{$\begin{array}{l}\text { entrada } \\
\text { entrada }\end{array}$} & & 34650,00 & 62309,00 & 48415,00 & 35594,00 & 49090,00 & 24083,00 & \\
\hline & & 36677,00 & 62717,00 & 49857,00 & 37686,00 & 52106,00 & 25524,00 & \\
\hline & média & 35663,50 & 62513,00 & 49136,00 & 36640,00 & 50598,00 & 24803,50 & \\
\hline & $\mathrm{FR}$ & & 1,75 & 1,38 & 1,03 & 1,42 & 0,70 & \\
\hline & conc & & 4,70 & 4,94 & 4,97 & 7,24 & 4,66 & 26,50 \\
\hline 4 & & 31137,00 & 16154,00 & 8727,00 & 4205,00 & 5273,00 & 2964,00 & \\
\hline \multirow[t]{4}{*}{4} & & 31741,00 & 15316,00 & 8761,00 & 4242,00 & 5361,00 & 3020,00 & \\
\hline & média & 31439,00 & 15735,00 & 8744,00 & 4223,50 & 5317,00 & 2992,00 & \\
\hline & FR & & 0,50 & 0,28 & 0,13 & 0,17 & 0,10 & \\
\hline & conc & & 1,47 & 0,92 & 0,62 & 0,86 & 0,56 & 4,42 \\
\hline \multirow[t]{3}{*}{8} & & 15629,00 & 6346,00 & 3371,00 & 2196,00 & 2748,00 & 1822,00 & \\
\hline & $\mathrm{FR}$ & & 0,41 & 0,22 & 0,14 & 0,18 & 0,12 & \\
\hline & conc & & 1,22 & 0,70 & 0,65 & 0,89 & 0,70 & 4,16 \\
\hline 12 & & 23649,00 & 11196,00 & 4917,00 & 2005,00 & 2293,00 & 1096,00 & \\
\hline \multirow[t]{4}{*}{12} & & 24447,00 & 11690,00 & 5094,00 & 2201,00 & 2303,00 & 1266,00 & \\
\hline & média & 24048,00 & 11443,00 & 5005,50 & 2103,00 & 2298,00 & 1181,00 & \\
\hline & $\mathrm{FR}$ & & 0,48 & 0,21 & 0,09 & 0,10 & 0,05 & \\
\hline & conc & & 1,40 & 0,67 & 0,39 & 0,48 & 0,24 & 3,18 \\
\hline \multirow[t]{3}{*}{16} & & 12745,00 & 3581,00 & 1376,00 & 287,00 & 0,00 & 141,00 & \\
\hline & FR & & 0,28 & 0,11 & 0,02 & 0,00 & 0,01 & \\
\hline & conc & & 0,90 & 0,30 & 0,07 & 0,00 & 0,00 & 1,28 \\
\hline \multirow[t]{3}{*}{20} & & 17005,00 & 1044,00 & 848,00 & 199,00 & 0,00 & 0,00 & \\
\hline & FR & & 0,06 & 0,05 & 0,01 & 0,00 & 0,00 & \\
\hline & conc & & 0,33 & 0,09 & 0,02 & 0,00 & 0,00 & 0,45 \\
\hline \multirow[t]{3}{*}{ saída } & & 28603,00 & 914,00 & 1109,00 & 271,00 & 0,00 & 0,00 & \\
\hline & FR & & 0,03 & 0,04 & 0,01 & 0,00 & 0,00 & \\
\hline & conc & & 0,26 & 0,05 & 0,01 & 0,00 & 0,00 & 0,31 \\
\hline
\end{tabular}




$\begin{array}{crrrrrrr}\text { L/D } & \text { area benzeno } & \text { area Clbz } & \text { FR } & \text { média FR } & \text { conc }(\mathrm{mg} / \mathrm{L}) & \text { curva } \\ \text { entrada } & 96063 & 31487 & 3,1 & 3,07 & 15,06 & \text { curva alta } \\ \text { entrada } & 89867 & 29057 & 3,1 & & & \\ & & & & & & \\ 4 & 45166 & 40153 & 1,1 & 1,27 & 6,83 & \text { curva alta } \\ 4 & 43107 & 30541 & 1,4 & & & \\ & & & & & & \\ 8 & 40376 & 34070 & 1,2 & 1,21 & 6,58 & \text { curva alta } \\ 8 & 40694 & 32707 & 1,2 & & & \\ 12 & 28257 & 32135 & 0,9 & 0,83 & 4,82 & \text { curva alta } \\ 12 & 28597 & 36832 & 0,8 & & & \\ 16 & 13475 & 25830 & 0,5 & 0,49 & 3,27 & \text { curva alta } \\ 16 & 13685 & 30039 & 0,5 & & & \\ 20 & 10998 & 27053 & 0,4 & 0,38 & 2,77 & \text { curva alta } \\ 20 & 12097 & 34435 & 0,4 & & & \\ & & & & & & \\ \text { saída } & 8905 & 34243 & 0,3 & 0,28 & 1,58 & \text { curva baixa } \\ \text { saída } & 9335 & 30640 & 0,3 & & & \end{array}$

\section{Perfil RAHLF 2 - alimentação com benzeno}

\begin{tabular}{crrrrrr} 
L/D & area benzeno & area Clbz & FR & média FR & conc & curva \\
entrada & 209084 & 23392 & 8,9 & 8,84 & 41,38 & curva alta \\
& 190805 & 21834 & 8,7 & & & \\
4 & 105579 & 24354 & 4,3 & 4,12 & 19,84 & curva alta \\
& 105461 & 27038 & 3,9 & & & \\
8 & 78188 & 24759 & 3,2 & 3,20 & 15,65 & curva alta \\
& 79440 & 24490 & 3,2 & & & \\
12 & 60113 & 23612 & 2,5 & 2,50 & 12,47 & curva alta \\
& 57560 & 23360 & 2,5 & & & \\
16 & 45349 & 33619 & 1,3 & 1,73 & 8,94 & curva alta \\
& 49350 & 23357 & 2,1 & & & \\
\multirow{2}{*}{20} & 34330 & 21771 & 1,6 & 1,48 & 7,82 & curva alta \\
& 37733 & 27102 & 1,4 & & & \\
\multirow{2}{*}{ saída } & 20870 & 27257 & 0,8 & 0,74 & 4,40 & curva alta
\end{tabular}




$\begin{array}{crrrrccc}\text { L/D } & \text { area Toluenc area Clbz } & \text { FR } & \text { média FR } & \text { conc }(\mathrm{mg} / \mathrm{l}) & \text { curva } \\ \text { entrada } & 26226 & 24309 & 1,1 & 1,088 & 7,6 & \text { curva alta } \\ \text { entrada } & 25055 & 22840 & 1,1 & & & \\ & & & & & & \\ 4 & 9329 & 25427 & 0,4 & 0,387 & 1,2 & \text { curva baixa } \\ 4 & 9945 & 24393 & 0,4 & & & \\ & & & & & & \\ 8 & 4395 & 21159 & 0,2 & 0,211 & 0,7 & \text { curva baixa } \\ 8 & 5408 & 25334 & 0,2 & & & \\ 12 & 2032 & 19921 & 0,10 & 0,100 & 0,3 & \text { curva baixa } \\ 12 & 2228 & 22507 & 0,10 & & & \\ 16 & 1082 & 25183 & 0,04 & 0,042 & 0,1 & \text { curva baixa } \\ 16 & 1270 & 31322 & 0,04 & & & \\ 20 & 0 & 25207 & 0,0 & 0,000 & 0,0 & \text { curva baixa } \\ & & & & & & \\ \text { saída } & 0 & 27233 & 0,0 & 0,000 & 0,0 & \text { curva baixa } \\ \text { saída } & 0 & 21100 & 0,0 & & & \end{array}$

Perfil RAHLF 2 - alimentação com tolueno

\begin{tabular}{|c|c|c|c|c|c|c|}
\hline$L / D$ & \multicolumn{2}{|c|}{ area tolueno area $\mathrm{Clbz}$} & $\mathrm{FR}$ & \multicolumn{2}{|c|}{ média FR conc $(\mathrm{mg} / \mathrm{L})$} & curva \\
\hline entrada & $\begin{array}{c}149893 \\
87886\end{array}$ & $\begin{array}{l}30000 \\
20828\end{array}$ & $\begin{array}{l}4,996 \\
4,220\end{array}$ & 4,61 & 27,8 & curva alta \\
\hline 4 & $\begin{array}{l}18538 \\
20841\end{array}$ & $\begin{array}{l}29827 \\
33744\end{array}$ & $\begin{array}{l}0,622 \\
0,618\end{array}$ & $\begin{array}{l}0,62 \\
0,31\end{array}$ & 1,9 & curva baixa \\
\hline 8 & $\begin{array}{l}10218 \\
12548\end{array}$ & $\begin{array}{l}33076 \\
31852\end{array}$ & $\begin{array}{l}0,309 \\
0,394\end{array}$ & 0,35 & 1,1 & curva baixa \\
\hline 12 & $\begin{array}{c}9034 \\
17945\end{array}$ & $\begin{array}{l}26970 \\
45199\end{array}$ & $\begin{array}{l}0,335 \\
0,397\end{array}$ & 0,37 & 1,1 & curva baixa \\
\hline 16 & $\begin{array}{c}13393 \\
8056\end{array}$ & $\begin{array}{l}61922 \\
37253\end{array}$ & $\begin{array}{l}0,216 \\
0,216\end{array}$ & 0,22 & 0,7 & curva baixa \\
\hline 20 & $\begin{array}{l}4102 \\
6332\end{array}$ & $\begin{array}{l}33591 \\
48303\end{array}$ & $\begin{array}{l}0,122 \\
0,131\end{array}$ & 0,13 & 0,4 & curva baixa \\
\hline saida & $\begin{array}{l}3430 \\
3352\end{array}$ & $\begin{array}{l}32778 \\
32877\end{array}$ & $\begin{array}{l}0,105 \\
0,102\end{array}$ & 0,10 & 0,3 & curva baixa \\
\hline
\end{tabular}




$\begin{array}{crrrrrr}\text { L/D } & \text { area m-xileno } & \text { area Clbz } & \text { FR } & \text { média FR } & \text { conc (mg/L) } & \text { curva } \\ \text { entrada } & 19267 & 25484 & 0,76 & 0,75 & 9,46 & \text { curva alta } \\ & & & & & & \\ 4 & 11607 & 37628 & 0,31 & 0,31 & 2,11 & \text { curva baixa } \\ 8 & 3019 & 24480 & 0,12 & 0,13 & 0,81 & \text { curva baixa } \\ 8 & 3961 & 31210 & 0,13 & & & \\ 12 & 3340 & 27341 & 0,12 & 0,12 & 0,79 & \text { curva baixa } \\ 12 & 3068 & 24643 & 0,12 & & & \\ 16 & 2738 & 22858 & 0,12 & 0,12 & 0,80 & \text { curva baixa } \\ 16 & 3337 & 26099 & 0,13 & & & \\ & & & & & & \\ \text { saída } & 2890 & 34407 & 0,084 & 0,08 & 0,51 & \text { curva baixa } \\ \text { saída } & 3458 & 41434 & 0,083 & & & \end{array}$

Perfil RAHLF 2 - alimentação com m-xileno

$\begin{array}{ccccccc}\text { L/D } & \text { area m- xileno } & \text { area Clbz } & \text { FR } & \text { Média FR } & \text { conc }(\mathrm{mg} / \mathrm{L}) & \text { curva } \\ \text { entrada } & 67674 & 28533 & 2,4 & 2,4 & 28,4 & \text { curva alta } \\ \text { entrada } & 74715 & 30692 & 2,4 & & & \\ & & & & & & \\ 4 & 8477 & 22174 & 0,382 & 0,4 & 5,3 & \text { Curva alta } \\ 4 & 11676 & 29977 & 0,389 & & & \\ & & & & & & \\ 8 & 22908 & 40336 & 0,568 & 0,6 & 3,9 & \text { Curva baixa } \\ 8 & 15892 & 28521 & 0,557 & & & \\ 12 & 10863 & 25083 & 0,433 & 0,4 & 3,0 & \text { Curva baixa } \\ 12 & 9283 & 20638 & 0,450 & & & \\ 16 & 10868 & 34342 & 0,316 & 0,3 & 2,0 & \text { Curva baixa } \\ 16 & 8409 & 29840 & 0,282 & & & \\ 20 & 4676 & 29924 & 0,156 & 0,2 & 1,0 & \text { Curva baixa } \\ 20 & 3411 & 21751 & 0,157 & & & \\ \text { saida } & 1725 & 33316 & 0,052 & 0,05 & 0,3 & \text { Curva baixa } \\ \text { saida } & 2136 & 39892 & 0,054 & & & \end{array}$


Perfil RAHLF 2 - alimentação com p-xileno

$\begin{array}{crrrrrr}\text { L/D } & \text { area p-xileno } & \text { area Clbz } & \text { FR } & \text { média FR } & \text { conc (mg/L) } & \text { curva } \\ \text { entrada } & 156298 & 17037 & 9,2 & 9,74 & 32,09 & \text { curva alta } \\ \text { entrada } & 250279 & 24284 & 10,3 & & & \\ & & & & & & \\ 4 & 26412 & 29599 & 0,9 & 0,91 & 4,95 & \text { curva alta } \\ 4 & 19656 & 21353 & 0,9 & & & \\ & & & & & & \\ 8 & 13138 & 18350 & 0,72 & 0,68 & 4,26 & \text { curva alta } \\ 8 & 14906 & 22995 & 0,65 & & & \\ 12 & 6401 & 22047 & 0,29 & 0,29 & 1,08 & \text { curva baixa } \\ 12 & 6634 & 23567 & 0,28 & & & \\ 16 & 1046 & 26004 & 0,04 & 0,04 & 0,19 & \text { curva baixa } \\ 16 & 1083 & 23180 & 0,05 & & & \\ 20 & 196 & 26473 & 0,01 & 0,01 & 0,06 & \text { curva baixa } \\ 20 & 201 & 29048 & 0,01 & & & \\ & & & & & & \\ \text { saída } & 226 & 22248 & 0,01 & 0,02 & 0,09 & \text { curva baixa } \\ \text { saída } & 669 & 31133 & 0,02 & & & \end{array}$

\section{Perfil RAHLF 2 - alimentação com o-xileno}

$\begin{array}{crrrrrrr}\text { L/D } & \text { area O-xileno } & \text { area Clbz } & \text { FR } & \text { média FR } & \text { conc }(\mathrm{mg} / \mathrm{L}) & \text { curva } \\ \text { entrada } & 99913 & 21571 & 4,6 & 4,45 & 28,52 & \text { curva alta } \\ \text { entrada } & 74270 & 17372 & 4,3 & & & \\ & & & & & & \\ 4 & 32685 & 36428 & 0,9 & 0,90 & 5,89 & \text { curva alta } \\ 4 & 31381 & 35049 & 0,9 & & & \\ & & & & & & \\ 8 & 17336 & 19725 & 0,88 & 0,86 & 5,67 & \text { curva alta } \\ 8 & 30909 & 36673 & 0,84 & & & \\ 12 & 29856 & 38026 & 0,79 & 0,76 & 5,00 & \text { curva alta } \\ 12 & 29269 & 40335 & 0,73 & & & \\ 16 & 16333 & 36849 & 0,44 & 0,46 & 3,13 & \text { curva alta } \\ 16 & 19401 & 40242 & 0,48 & & & \\ & & & & & & & \\ 20 & 4106 & 26358 & 0,16 & 0,16 & 1,05 & \text { curva baixa } \\ & & & & & & \\ \text { saída } & 9701 & 36582 & 0,27 & 0,26 & 1,81 & \text { curva baixa } \\ \text { saída } & 7271 & 28302 & 0,26 & & & \end{array}$


Perfil RAHLF 2 - alimentação com BTEX

$$
\text { L/D }
$$

entrada

$\begin{array}{cccc} & & 28391,00 & 46049,00 \\ & \text { média } & 26642,00 & 44325,00 \\ & \text { FR } & & 1,66 \\ 4 & \text { conc } & & \mathbf{4 , 4 7} \\ 4 & & 25184,00 & 22679,00 \\ & & 29396,00 & 24616,00 \\ & \text { média } & 27290,00 & 23647,50 \\ & \text { FR } & & 0,87 \\ 8 & \text { conc } & & \mathbf{2 , 4 1} \\ 8 & & 24606,00 & 16332,00 \\ & \text { média } & 26606,00 & 15550,00 \\ & \text { FR } & & 15941,00 \\ & \text { conc } & & 0,62 \\ 12 & & 25971,00 & 17248 \\ 12 & \text { média } & 27653,00 & 17126,00 \\ & \text { FR } & & 17186,00 \\ & \text { conc } & & 0,64 \\ 16 & & 27041,00 & 16831,00 \\ 16 & & 26391,00 & 17835,00 \\ & \text { média } & 26716,00 & 17333,00 \\ & \text { FR } & & 0,65 \\ & \text { conc } & & \mathbf{1 , 8 5} \\ 20 & & 27660,00 & 10068,00 \\ 20 & & 28468,00 & 9661,00 \\ & \text { média } & 28064,00 & 9864,50 \\ & \text { FR } & & 0,35 \\ & \text { conc } & & \mathbf{1 , 0 8} \\ \text { saída } & & 27769,00 & 3405,00 \\ \text { saída } & & 25987,00 & 3398,00 \\ & \text { média } & 26878,00 & 3401,50 \\ & \text { conc } & & \mathbf{0 , 5 0} \\ & & & \end{array}$

área tolueno 34035,00 37251,00 35643,00

1,34 4,79

11377,00

12625,00

12001,00

0,44

1,51

7584,00

7064,00

7324,00

0,29

0,95

8622,00

8404,00

8513,00

0,32

1,07

8209,00

8801,00

8505,00

0,16
0,49

5746,00

5181,00

5463,50

0,19

1643,00

1650,00

1646,50 área etilbz

27321,00

30330,00

28825,50

1,08

5,23

5387,00

6090,00

5738,50

0,21

0,99
3492,00

3173,00

3332,50

0,13

0,60

4200,00

3972,00

4086,00

0,15

0,71

4125,00

4419,00

4272,00

0,16

2463,00

2223,00

2343,00

0,08

0,37

1050,00

1064,00

1057,00

0,16 área $\mathrm{mp}$-xilenos área o-xileno 53773,00

59721,00

56747,00

2,13

$$
10,87
$$

10438,00

11827,00

11132,50

0,41

2,07

6779,00

6119,00

6449,00

0,25

1,28

8307,00

7791,00

8049,00

0,30

1,52

8708,00

9324,00

9016,00

0,34

1,71

5331,00

4803,00

5067,00

0,18

0,91

2339,00

2359,00

2349,00

0,44
31187,00

29841,50

$$
\begin{aligned}
& 1,12 \\
& 7,56
\end{aligned}
$$

6283,00

7074,00

6678,50

0,24

4138,00

3709,00

3923,50

0,15

0,95

5259,00

4851,00

5055,00

0,19

5405,00

5757,00

5581,00

0,21

3070,00

2793,00

2931,50

0,10

$\mathbf{0 , 6 2}$

1168,00

1212,00

1190,00

0,21 


\section{APÊNDICE J- Perfil espacial da concentração de amônia no RALHF}

Quadro 14 - Valores das medidas de concentração de amônia avaliada ao longo dos reatores RAHLF 1 e RAHLF 2

\begin{tabular}{lllll}
\hline \multicolumn{1}{c}{ Reator } & Absorbância & Absorbância & Média & $\mathrm{mg} / \mathrm{L}$ \\
\hline RAHLF 1 & & & & \\
Entrada & 0.081 & 0.079 & 0.08 & 6.69 \\
4 & 0.025 & 0.023 & 0.024 & - \\
8 & 0.018 & 0.016 & 0.017 & - \\
12 & 0.013 & 0.015 & 0.014 & - \\
16 & 0.018 & 0.017 & 0.0175 & - \\
20 & 0.021 & 0.022 & 0.0215 & - \\
Saída & 0.02 & 0.018 & 0.019 & - \\
& & & & \\
RAHLF 2 & & & & \\
\hline Entrada & 0.084 & 0.081 & 0.0825 & 7.27 \\
4 & 0.022 & 0.023 & 0.0225 & - \\
8 & 0.009 & 0.009 & 0.009 & - \\
12 & 0.011 & 0.011 & 0.011 & - \\
16 & 0.013 & 0.015 & 0.014 & - \\
20 & 0.015 & 0.014 & 0.0145 & - \\
Saída & 0.015 & 0.017 & 0.016 & - \\
\hline
\end{tabular}

Equação da reta da curva de calibração utilizada: $y=125,45 x-3,0762$ onde $R^{2}=0,9943$ e $\mathrm{x}=$ concentração em $\mathrm{mg} / \mathrm{L}$ de $\mathrm{NH}_{4}^{+}$ 


\section{APÊNDICE K - Estimativa da biodegradação no RALHF}

A análise de biodegradação do presente estudo foi estimada a partir dos valores de adsorção na espuma e na biopartícula, relatados por Nardi (2002). De acordo com este autor, os valores máximos de adsorção encontrados foram:

Quadro 15 - Valores da adsorção dos tóxicos na biopartícula e meio suporte calculados por Nardi (2002).

\begin{tabular}{lll}
\hline Composto & $\mathrm{F}_{\mathrm{sp}}^{\mathrm{Max}}(\mu \mathrm{mol} / \mathrm{g}$ suporte $)$ & $\mathrm{R}^{2}$ \\
\hline Espuma de poliuretano & & \\
Tolueno & $35,18 \pm 0,72$ & 0,8891 \\
Etilbenzeno & $42,16 \pm 0,36$ & 0,9891 \\
0-xileno & $40,62 \pm 0,40$ & 0,9850 \\
Benzeno & 27,0 & \\
\hline Biopartícula & & \\
Benzeno & $12,81 \pm 1,21$ & 0,7285 \\
Tolueno & $16,93 \pm 0,81$ & 0,9185 \\
Etilbenzeno & $19,10 \pm 0,80$ & 0,9009 \\
0-xileno & $18,36 \pm 0,79$ & 0,8916 \\
\hline
\end{tabular}

Com esses valores como base, efetuaram-se os cálculos a seguir, para estimar a biodegradação ocorrida nos reatores do presente estudo.

Valores da adsorção de cada tóxico, para as condições operacionais do reator RAHLF1, levando-se em conta os valores de adsorção no meio suporte e biopartícula do estudo de Nardi (2002).

$\mathrm{M}_{\text {mol }}=\mathrm{F}_{\mathrm{sp}}^{\mathrm{Max}} \cdot \mathrm{M}_{\mathrm{esp}}+\mathrm{M}_{\mathrm{bio}} \cdot \mathrm{STV}$, onde:

$\mathrm{M}_{\mathrm{mol}}=$ massa total do tóxico adsorvida na espuma e biopartícula ( $\left.\mu \mathrm{mol}\right)$

$\mathrm{F}_{\mathrm{sp}}{ }^{\mathrm{Max}}=$ capacidade de adsorção do tóxico na espuma de poliuretano $(\mu \mathrm{mol} / \mathrm{g})$ relatado por Nardi (2002)

$\mathrm{M}_{\mathrm{esp}}=$ massa de espuma de poliuretano usada no reator $(\mathrm{g})$.

$\mathrm{M}_{\text {bio }}=$ capacidade de adsorção do tóxico na biopartícula $(\mu \mathrm{mol} / \mathrm{g})$ relatado por Nardi

$\mathrm{STV}=$ massa referente aos sólidos totais voláteis $(\mathrm{g})=0,57 \mathrm{~g} / \mathrm{g}$ espuma. Valor referente aos sólidos totais voláteis, obtidos ao final do período de operação do reator desnitrificante, ensaiado por Nardi (2002)

Então para cada tóxico tem-se: 
$\mathrm{M}_{\text {mol (tolueno) }}=35,18 \mu \mathrm{mol} / \mathrm{g} \cdot 25 \mathrm{~g}+16,93 \mu \mathrm{mol} / \mathrm{g} \cdot 0,57 \mathrm{~g}=889,15 \mu \mathrm{mol}$

$1 \mathrm{~mol}$ de tolueno $=>92,14 \mathrm{~g}$

$889,15.10^{-6} \mathrm{~mol}=>\mathrm{x}$ onde $\mathrm{x}=\mathbf{8 1 , 9 3} \mathbf{m g}$ de tolueno.

$\mathrm{M}_{\text {mol (etilbenzeno) }}=42,16 \mu \mathrm{mol} / \mathrm{g} \cdot 25 \mathrm{~g}+19,10 \mu \mathrm{mol} / \mathrm{g} \cdot 0,57 \mathrm{~g}=1064,89 \mu \mathrm{mol}$

$1 \mathrm{~mol}$ de etilbenzeno $=>106,16 \mathrm{~g}$

$1064,89.10^{-6} \mathrm{~mol}=>\mathrm{x}$ onde $\mathbf{x}=\mathbf{1 1 3 , 0 5} \mathbf{~ m g}$ de etilbenzeno.

$\mathrm{M}_{\text {mol (m-xileno) }}=40,62 \mu \mathrm{mol} / \mathrm{g} \cdot 25 \mathrm{~g}+18,36 \mu \mathrm{mol} / \mathrm{g} \cdot 0,57 \mathrm{~g}=1025,96 \mu \mathrm{mol}$

$1 \mathrm{~mol}$ de o-xileno $=>106,16 \mathrm{~g}$

$1025,96 \cdot 10^{-6} \mathrm{~mol}=>\mathrm{x}$, onde $\mathbf{x}=\mathbf{1 0 8 , 9 2} \mathbf{~ m g}$ de o-xileno.

$\mathrm{M}_{\text {mol (benzeno) }}=27,00 \mu \mathrm{mol} / \mathrm{g} \cdot 25 \mathrm{~g}+12,81 \mu \mathrm{mol} / \mathrm{g} \cdot 0,57 \mathrm{~g}=682,30 \mu \mathrm{mol}$

$1 \mathrm{~mol}$ de benzeno $=>78,11 \mathrm{~g}$

$682,30 \cdot 10^{-6} \mathrm{~mol}=>x$ onde $x=53,29 \mathbf{~ m g}$ de benzeno.

A seguir calculou-se o total de tóxico que passou pelo reator pelo equacionamento:

$\mathrm{M}=\mathrm{Q}\left[\mathrm{C}_{0}-\mathrm{C}_{\mathrm{s}}\right] \tau$, onde:

$\mathrm{M}=$ quantidade de tóxico que passou pelo reator em $(\mathrm{mg})$.

$\mathrm{Q}=$ vazão de operação do reator em $(\mathrm{l} / \mathrm{h})$.

$\mathrm{C}_{0}=$ concentração do tóxico na entrada do reator em $(\mathrm{mg} / \mathrm{l})$.

$\mathrm{C}_{\mathrm{s}}=$ concentração do tóxico na saída do reator em (mg/l).

$\tau=$ tempo de operação do reator em (h), para cada tóxico. 
Quantificando-se os tóxicos estudados tem-se:

$\mathrm{M}_{\text {tolueno }}=0,07 \mathrm{l} / \mathrm{h} \cdot(30,8-0,1) \mathrm{mg} / \mathrm{l} .1008 \mathrm{~h}=2166,19 \mathrm{mg}$

$\mathrm{M}_{\text {etilbenzeno }}=0,07 \mathrm{l} / \mathrm{h} .(33,3-0,4) \mathrm{mg} / \mathrm{l} .360 \mathrm{~h}=829,08 \mathrm{mg}$

$\mathrm{M}_{\mathrm{m} \text {-xileno }}=0,07 \mathrm{l} / \mathrm{h} .(32,1-0,1) \mathrm{mg} / \mathrm{l} .360 \mathrm{~h}=806,4 \mathrm{mg}$

$\mathrm{M}_{\text {benzeno }}=0,07 \mathrm{l} / \mathrm{h}$. $\left.(26,5-0,4) \mathrm{mg} / \mathrm{l} .648 \mathrm{~h}=1183,89 \mathrm{mg}\right)$

$\left.\mathrm{M}_{\text {benzeno }}=0,07 \mathrm{l} / \mathrm{h} .(13,8-0,9) \mathrm{mg} / \mathrm{l} .576 \mathrm{~h}=520,12 \mathrm{mg}\right\}$

$\mathbf{M}_{\text {total benzeno }}=2989,2 \mathrm{mg}$

$\mathrm{M}_{\text {benzeno }}=0,07 \mathrm{l} / \mathrm{h} .(15,4-0,1) \mathrm{mg} / \mathrm{l} .1200 \mathrm{~h}=1285,2 \mathrm{mg}$

Finalmente, o cálculo que nos permite estimar a biodegradação é feito pela diferença entre a quantidade de tóxico que passou pelo reator e a massa de tóxico que foi adsorvida pelo meio suporte e biomassa

\begin{tabular}{|l|c|c|c|}
\hline composto & Massa do tóxico(mg) & $\begin{array}{c}\text { Massa adsorvida } \\
\text { (espuma + biopartícula)(mg) }\end{array}$ & $\begin{array}{c}\text { Biodegradação } \\
\text { (mg) }\end{array}$ \\
\hline Tolueno & 2166,19 & 81,93 & 2084,26 \\
\hline Etilbenzeno & 829,08 & 113,05 & 716,03 \\
\hline m-xileno & 806,4 & 108,92 & 697,48 \\
\hline Benzeno & 2989,20 & 53,29 & 2935,91 \\
\hline
\end{tabular}

Para a operação do reator RAHLF 2 adotou-se o mesmo procedimento.

\begin{tabular}{|l|c|c|c|}
\hline \multicolumn{1}{|c|}{ composto } & Massa do tóxico(mg) & $\begin{array}{c}\text { Massa adsorvida } \\
\text { (espuma + biopartícula)(mg) }\end{array}$ & $\begin{array}{c}\text { Biodegradação } \\
(\mathrm{mg})\end{array}$ \\
\hline Tolueno & 1213,8 & 81,93 & 1131,87 \\
\hline Etilbenzeno & 3581,83 & 113,05 & 3468,78 \\
\hline o-xileno & 660,24 & 108,92 & 551,32 \\
\hline m-xileno & 903,59 & 108,92 & 794,67 \\
\hline p-xileno & 806,4 & 108,92 & 697,48 \\
\hline Benzeno & 1464,96 & 53,29 & 1411,67 \\
\hline
\end{tabular}

